\title{
ANÁLisE GENÉTICA DE UM DIALELO ENTRE GENÓTIPOS PRECOCES DE SOJA [GLYCINE MAXX (L.) MERRILL]
}

\author{
FRANCISCO RODRIGUES FREIRE FILHO \\ Engenheiro Agrōnomo
}

Orientador: Prof. Dr. NATAL ANTONJO VELIO

Tese apresentada à Escola Superior de Agricultura "Luiz de Queiroz", da Uni versidade de São Paulo, para obtenção do título de Doutur en Agronomia. Area de Concentração: Genética e Melhoramento de Plantas.

$P I R A C I C A B A$

Estado de São Paulo-Brasil Abril - 1988 
Freire Filho, Francisco Rodrigues
Anälise genética em um dialelo entre genöti-
pos precoces de soja Glycine max (L.) Merrill.
Piracicaba, 1988.
224p. ilus.
Tese - ESALQ
Bibliografia
1. Soja - Cruzamento dialélico. 2. Soja -
Genética. I. Escola Superior de Agricultura
Luiz de Queiroz, Piracicaba. 
ANÁLISE GENETICA DE UM DIALELO ENTRE GENŌTIPOS PRECOCES DE SOJA [Glycine max (L.) MERRIL]

FRANCISCO RODRIGUES FREIRE FILHO

Aprovada em 19.04.88

Comissão Julgadora:

Prof. Dr. Natal Antonio Vello ESALQ/USP

Prof. Dr. Décio Barbin ESALQ/USP

Prof. Dr. Gerhard Bandel ESALQ/USP

Prof. Dr. Júlio Marcos Filho ESALQ/USP

Prof. Dr. Isaias olívio Geraldi ESALQ/USP$$
y-1-1 \mid 115
$$ \\ Prof. Dr. Natal Antonio Vello \\ Orientador
}


ii.

A minha mãe Neide

A minha avó Laura

A memória de miriha tia Nereide

Aomeupai Francisco e aos meus

irmãos

DEDICO

A minha esposa Cézia

Aos meus fizhos simei $e$ samue?

OPERESO 


\section{AGRADECIMENTOS}

A Deus que me possibilitou alcançar este importante e alme jado objetivo;

Ao Professor Dr. Natal Antonio Vello pela atenção, orienta ção, ensinamentos e decisiva colaboração na realização deste trabalho;

A Empresa Brasileira de Pesquisa Agropecuāria (EMBRAPA) e ao Departamento de Genética da Escola Superior de Agricultura "Luiz de Queiroz" - ESALQ, que me possibilitaram a realização deste curso;

Aos Professores do Departamento de Genética da ESALQ, pela atenção e ensinamentos e em particular aos professores Drs. Gerhard Bandel e Roland Vencovsky que juntamente com o professor Natal Antonio Vello, compuseram a banca do meu exame geral de qualificação;

Aos colegas Clodoaldo Josē da Anunciação Filho e Marcos Kazuyuki Kamikoga pela atenção e indispensāvel colaboração nos trabalhos experimentais;

A todos os colegas do curso e em particular a clodoaldo Jo sê da Anunciação Filho, Gotaräo Marcon, Eleusio Curvelo Freire, Francisco Berilo Façanha Mameảe, João. Ribeiro Crisóstomo e Dario Minoro Hiromoto pela amizade, apoio e agradável convívio proporcionarlo;

Ao Professor Cosme Damião Cruz, da Universidade Feäeral de Viçosa e ao Dr. Wìlson Roberto Maluf, da empresa Eioplan ta, pela cessão dos programas de computação para as análises dialélicas e de correlações e aos colegas Roberto Augusto de Almeida Turres e João Eustäquio Cabral de Miranda pelo apoio para a obtenção desses programas e realização dessas anălises; 
Aos funcionários do Laboratório de Soja, Antonio Roberto Cogo, Claudinei Antonio Didoné, Osmair José da Silva e Adnilson Lambertucci e ainda aos funcionários orides Alves Cardoso e Álvaro Gomes pela atenção e dedicação na reali zação dos trabalhos de campo e de laboratório;

Às funcionārias da Biblioteca Nilce T.P. Sigrist, Terezinha de Jesus L. Barrete e Olivia R. Pachane e à secretāria Gerda Spruk do Departamento de Genētica da ESALQ pela atenção e presteza;

Ao Conselho Nacional de Desenvolvimento Científico e Tecnológico-CNPq, pela concessão da bolsa de estudo;

Ao Dr. Elmano Ferrer de Almeida e ao Dr. Milton José Cardoso, respectivamente Chefe e Sub-chefe da UEPAE de Teresi na - EMBRAPA, pela atenção e colaboração para a minha permanência em Piracicaba para conclusão definitiva do curso;

À minha esposa, Célia, e aos meus filhos, Simei e Samuel, pelo apoio e incentivo;

$\bar{A}$ Maria Helena M.O. Rodrigues pelos serviços datilográficos. 


\section{SUMARIO}

Pâgina

RESUMO

vii

SUMMARY

$x i$

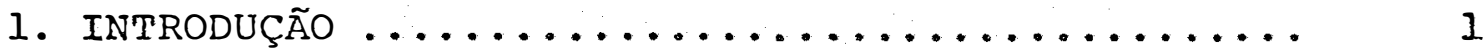

2. REVISÃO DE IITERATURA ............................. 5

2.1. Ação gênica ...................... 7

2.2. Capacidade de combinação ............. 15

2.3. Heterose e heterobeltiose ............. 20

2.4. Correlações entre caracteres ........... 27

2.5. Esquemas de cruzamento ............... 31 .

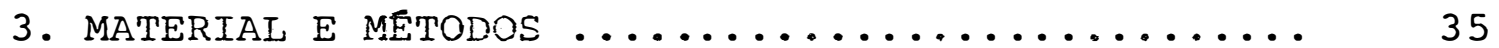

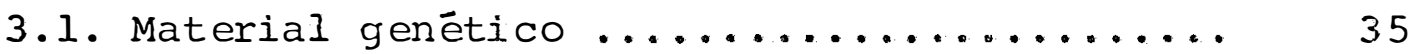

3.2. Caracterização do ambiente ........... 35

3.3. Procedimentos experimentais ............ 36

3.4. Anälises estatístico-genēticas .......... 41

3.5. Heterose e heterobeltiose .............. 64

3.6. Cruzamentos em cadeia ............... 65

4. RESULTADOS E DISCUSSÃO ......................... 70

4.1. Anālise de variância ................ 70

4.2. Comportamento dos parentais, progênies $\mathrm{F}_{2} \mathrm{e}$ avaliação da. heterose e heterobeltiose.... 75

4.3. Correlações entre caracteres ............ 98

4.4. Análise dialëlica de Hayman ............ 102 
$v i$

4.5. Análise dialélica de Griffing ............ 135

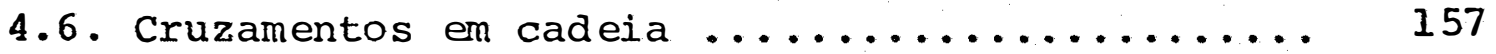

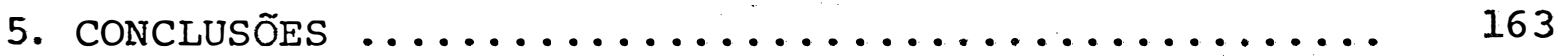

REFERENCIAS BIBLIOGRĂFICAS ................... 1.66

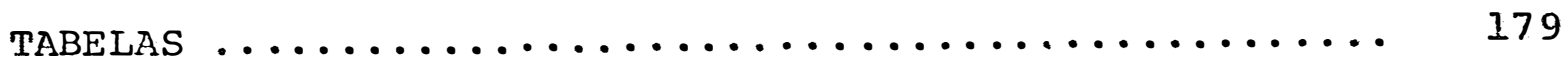

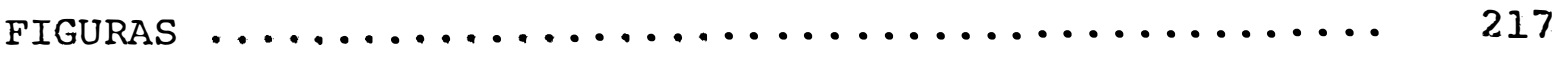


vii.

\section{ANÁLISE GENÉTICA DE UM DIALELO ENTRE GENÓTIPOS PRECOCES DE SOJA [GLYCINE MAX (L.) MERRILL]}

Autor: FRANCISCO RODRIGUES FREIRE FILHO Orientador: Prof. Dr. NATAL ANTONIO VELLO

\section{RESUMO}

o presente trabalho teve como objetivos principais avaliar o potencial para melhoramento de cruzamentos entre genótipos precoces de soja e comparar a eficiência para obtenção de variabilidade dos esquemas de recombinação que utilizam cruzamentos em cadeia e cruzamentos dialélicos. Foram utilizados os seguintes genótipos, incluindo cultivares comerciais e linhagens experimentais: Paranā, IAC-Fosca rin-31, Coker 136, Primavera, Década, Forrest, FT 81 - 1835 , SOC 81-79, Hale 321 e Palmetto. Esses genōtipos foram delibe radamente escolhidos para esse estudo, de modo que as conclu sões obtidas referem-se a eles próprios e suas progênies.

O estudo incluiu os dez pareritais e suas 45 progênies $\mathrm{F}_{2}$. Todos os trabalhos foram realizados no setor de Genētica Aplicada às Espēcies Autógamas do Instituto de 
viii.

Genētica da ESALQ/USP e o experimento foi conduzido no Campus da ESALQ, em Piracicaba-SP, no período de outubro/86 a abril/87. O ambiente é caracterizado por situar-se a

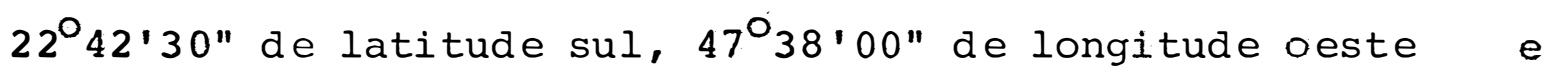
537 m àe altitude. Foi usadoodelineamento em látice 8 x 8 , tendo-se para isso incluído nove tratamentos adicionais. Foram feitas seis repetições sendo cada parcela representada por uma fileira de $5 \mathrm{~m}$ de comprimento. O espaçamento foi de 1,0 m entre fileiras, deixando-se após o desbaste, dezz plantas por metro linear. Foram avaliados os seguintes caracteres: número de dias para o florescimento (NDF) e para maturidade (NDM); número de internódios no florescimento(NIF) e na matiuridade(NIM); altura da planta no florescimento (APF) e na maturidade ( $A P M)$; acamamento (AC), valor agronômico (VA) e produtividade de plantas individuais (PPI) e da parce la (PP), na maturidade.

Com exceção dos caracteres APF e APM o látice não apresentou eficiência em relação a blocos casualizados; desse modo, foram excluídos os tratamentos adicionais e as anālises foram refeitas em blocos. Os estudos genēticos compreenderam estimativas de heterose e heterobeltiose, cor relaçōes, anālise dialélica de HAYMAN (1958), anālise da capacidade de combinação através do método 2 , modelo misto $B$ de GRIFFING (1955b) e avaliação da eficiència do esquema de cruzamento en cadeia para obtenção de variabilidade. 
A partir das anälises realizadas, foram obtidas as seguintes conclusões: a) os parentaj.s e progênies $F_{2}$ foram significativamente diferentes entre si para todos os caracteres, revelando um grande potencial para a formação de uma população de ampla base genêtica; b) para todos os caracteres houve uma ampla variação da heterose e da heterobel tiose, porëm nem sempre as maiores heteroses e heterobeltioses estiveram associadas às maiores mëảias e variäncias; c) as correlações genotípicas foram geralmente maiores que as fenotípicas e de ambiente. As correlações fenotípicas geral mente apresentaram o mesmo sinal da genotípica, de modo que o fenōtipo refletiu satisfatoriamente o genötipo. os caracteres relacionados àmaturidade mostraram-se ser os mais importantes para o melhoramento da produtividade; d) a anälise gräfica revelou sobredominância para a maioria dos caracteres, porém, na anālise numërica a variância aditiva reve lou-se mais importante. As herdabilidades foram relativamen te altas, com exceção da herdabilidade no sentido restrito nos caracteres produtividade da parcela $\left(h_{r}^{2}=0,132\right)$, valor agronômico $\left(h_{r}^{2}=0,289\right)$ e altura da planta na maturidade $\left(h_{x}^{2}=0,335\right) ;$ e) a CGC foi mais importante que a CEC, com a relação CGC/(CGC + CEC), sendo superior a 0,7 em todos cs ca racteres. As estimativas de $g_{i}, s_{i j}$ e $s_{i j}$ para $i \neq j$, apresentaram uma ampla variação para toajos os caracteres. Para produtividade, os parentais IAC-Foscarin-3i, Palmetto, SOC 81-79 e Primavera, apresentaram consistentemente os mellores 
valores de $g_{i}$, alérn disso participaram dos melhores cruzamen tos para esse carāter; e f) o cruzamento em cadeia representou satisfatoriamente o cruzamento dialélico en termos de mé dia e variabilidade genētica e se constituiu uma alternativa de melhor aplicabilidade para a formação de populações bäsicas para uso em programas de seleção recorrente. 
$x i$

\section{GENETIC ANALYSIS OF A DIALLEL AMONG EARLY SOYBEAN [GLYCINE MAX $\left(L_{1}\right)$ MERRILL] GENOTYPES}

Author: FRANCISCO RODRIGUES FREIRE FILHO Adviser: Prof. Dr. NATAL ANTONIO VELLO

\section{SUMMARY}

Earliness is a neea for growing two or more crops in a same agricultural year. This research aimed to study ten parents and their 45 diallel crosses ( $F_{2}$ progeries) for evaluating the breeding potential, the type of genetic control of agronomic characters, the combiningability, and the efficiency of a chain design in terms of mean and genetic variability released in comparison to the diallel design. Based on earliness and performance in previous yield test, ten cultivars and/or experimental lines were chosen as parents: Paranā, IAC-Foscarin-31, Coker 136, Primavera, Dëcada, Forrest, FT 81-1835, SOC 81-79, Hale 321, Palmetto. The field experiment was carried out in Genetic Institute, Faculty of Agriculture "Luiz de Queiroz" (ESALQ), University of São Paulo (USP), located in Piracicaba, state of São Paulo, Brazil, at $22^{\circ} 42^{\prime} 30^{\prime \prime}$ South latitude, $47^{\circ} 38^{\prime} 00^{\prime \prime}$ west 
xii.

longitude and $537 \mathrm{~m}$ altitude. The experimental design was a $8 \times 8$ lattice with nine additional treatments and six replications. Plot consisted of a row $5 \mathrm{~m}$ long with 50 plants. The spacing between rows was $1 \mathrm{~m}$. Ten characters were evaluated: time to flowering (NDF), and to maturity (NDM), number of internodes in flowering (NIF), and inmaturity (NIM), plant height in flowering ( $A P F$ ) and in maturity (APM), lodging ( $A C)$, agronomic value (VA), seed yield of individual plant (PPI) and of plot (PP). Each character was evaluatca in 12 random plants per plot; PP included 12 individual plants and the ramaining plants of each plot. Because lattice design was not efficient, the analyses were made in a complete randomized block design. The genetic analysis involved heterosis, heterobeltiosis, correlation between characters, Hayman's diallel analysis, Griffing's combining ability analysis (method 2, model mixed B), comparison between chain and diallel designs. The following conclusions were taken: a) Heterosis and heterobeltiosis values showed largevariation across crosses for all characters, and the largest values were not always associated to the largest means and variances. b) Generally, genotypic variances were larger than phenotypic and environmental variances; tharacters related to maturity (NDM, NIM, APM) were highIy correlated to seedyield. c) Hayman's plot analysis revelead overdominance in all characters, and additive variance was the most important component in numerical analysis. d) The estimates of narrow sense heritability were superior to 0.60 , except for 
$x i i i$.

(0.13), $\operatorname{VA}(0.29)$, and $\operatorname{APM}(0,34):$ e) General combining ability represented more than $70 \%$ and specific combining ability less than $30 \%$ of all characters variability: f) Superior values of $g_{i}$ and highest mean performances occurred in the crosses involving the following parents: IAC-Foscarin-31, Palmetto, SOC 81-79, and Primavera. g) The ten parent set presented genetic variability and complementary characters in apropriate levels to synthesize a population with broad genetic base for recurrent selection. h) Chain design showed mean and genetic variability in comparable levels to the diallel design, thus, becoming a practical alternative for various cycles of recombination of multiple $(\mathrm{n} \geq 10)$ parents in recurrent selection programs of autogamous species. 


\section{INTRODUC̆̃̃O}

A soja é uma cultura de grande importância mundial, apresentando uma produção crescente, a qual ultrapassou a casa dos 100 milhões de toneladas de grãos no ano de 1985 (FAO PRODUCTION YEARBOOKS, 1986). Acredita-se que o interesse mundial pelo cultivo da soja deva-se à excelente combinação que ela apresenta em termos de produtiviaade (geralmente superior a $2 t / h a)$ e porcentagens de óleo e protejna, em média, respectivamente 20 e $40 \%$ do peso das sementes (VELLO, 1985).

No Brasil a soja è uma cultura de destaque pe lo valor econômico de sua produção, pella sua participação na alimentação humana, principalmente na forma de óleo, no arraçoamento animal, na forma de farelo e ainàa como uma importante fonte de absorção de mão-de-obra, tanto na lavoura como na indūstria. Desảe 1975 o Brasil è o segundo produtor mundial de soja. Im 1986 a produção brasileira foi de 13.334 .691 t em uma ärea de 9.185 .551 ha, o que resulta numa pro dutividade de 1,45 t/ha (ANUÉRIO ESTATISTICO DO BRASIL; 1986). 
Segundo BONATO \& DALL'AGNOLL (1985) o cultivo da soja tornou-se economicamente importante na década de 60 . Entretanto, embora relativamente recente no país, o cultivo da soja já tornou-se uma prática tradicional nas regiões Sul e Sudeste, encontrando-se em franca expansão nas regiões Cen troeste e Nordeste. Essa situação faz com que a cada ano sejam exigidos cultivares mais produtivos para as áreas tradicionais e cultivares que possam se adaptar às áreas em expan são e tambēm aos sistemas específicos de produção, como por exemplo a rotação de culturas. Nesse caso se inclui o culti vo da soja no período entre o corte da última soca(julho) e o próximo plantio da cana (fevereiro), no Estado de São Pau10. Para uso nestes sistemas, os cultivares devem ter produ tividade el evada e precocidade apropriada para não atrasar o plantio dà cultura subsegüente (canamde-açúcar ou outra graminea).

Portanto, para atender a objetivos tão diversos è imprescindivel que se disponha de uma ampla variabilj-dade genética. Contudo, HIROMOTO \& VELLO (1986) mostraram que dos 74 cultivares recomendados para cultivo no ano agxicola 1983-84, 69 foram obtidos basicamente de 11 ancestrais com contribuições individuais variäveis de 3 a $15 \%$ e contribuição acumulada de cerca de $90 \%$ do conjunto gênico; alguns destes ancestrais foram prncedentes das mesmas regiões da China e da Coréia. Esses dados mostram que a base genética 
do germoplasma de soja adaptado às condições brasileiras é muito restrita.

Essa realidade torna necessārio que alguns as pectos do melhoramento, geralmente colocados em segundo pla-no, passem a receber maior atenção para que sejam obtidos ga nhos reais de produtividade, adaptação e para que seja diminuída a vulnerabilidade genētica do material cultivado. Entre esses aspectos sobressaem-se a necessidade de um conheci mento mais preciso do potencial genético dos cultivares pa-rentais, da capacidade de combinação e do grau de parentesco entre eles, neste caso para evitar o cruzamento entre materiais muito aparentados.

Esse trabalho faz parte do Programa de Soja do Setor de Genētica Aplicada às Espēcies Autōganas do Ins.tituto de Genētica da Escola Superior de Agricuitura "Luiz de Queiroz" "da Universidade de são Paulo, que entre seus objetivos visa ampliar a base genētica do germoplasma de soja adaptado às condições brasileiras. Este estudo envolve genōtjpos precoces e ten os seguintes objetivos principais:

a) avaliar o potencial genético e a capacidade de combinação desses materiais;

b) estimar parámetros genéticos para caracteres agro nômicos: 
c) identificar os cruzamentos de maior potencial com base na média, na variância da geração $F_{2}$ e na ca pacidade de combinação dos parentais;

d) avaliar a eficiência do esquema de cruzamento em cadeia em relação ao dialelo completo para a obtenção de variabilidade. 


\section{REVISÃO DE LITERATURA}

A soja è uma planta autógama e anual que pertence à família Leguminosae, subfamília Papilionoideae, tribo Phaseoleae, subtribo Phaseolinae (Glycininae), gênero Glu cine I., subgênero Soja (Moench) F.J. Germ. e à espécie Goycine $\max (\mathrm{L}$,$) Merrill, tendo 2 \mathrm{n}=40$ cromossomos.

Não hā concordância entre diferentes autores quanto ao local específico a partir do qual a soja cultivada surgiu, entretanto, há um consenso de que sua origem se deu na região leste da Āsia (BONETTI, 1981). HYMOWITZ (1970) ad mitiuque a soja emergiu como planta cultivada por volta do sëculo XI A.C. na região nordeste da China, região que muito provavelmente foi o centro genëtico da espëcie. Dessa regịão o cultivo da soja expandiu-se para outras regiões do país e para outros paỉses asiáticos, possivelmente no período que vai do ano 1027 ao ano 221 A.C.. Ainda nessa região; na ārea correspondente a antiga Manchúria, a soja teve um grande desenvolvimento, tornando-se essa ārea um centro genẹ tico secundärio da espëcie. 
A partir da Asia a soja chegou à Europa no início do século XVIII, à América do Norte no início do sécu lo XIX e no final desse mesmo século à América do sul (BONETTI, 1981).

No Brasil, os relatos indicam que a soja foi aqui introduzida ainda no século XIX, entretanto, seu cultivo só alcançou uma larga escala na década de 70 , quando no período de 1970 a 1977 a produção teve um crescimento anual de 32\% (BONATO \& DAL'AGNOLL, 1985). As regiões Sul e sudeste foram o berço da cultura no país, sendo o Rio Grande do sul o estado a partir do qual se deu a grande expansão da cultura. Hoje a soja è cultivada em praticamente todas as regiöes do Brasil, sendo ainda essas regiões os principais centros de prođução. As regiões centroeste e Nordeste constituem as principais āreas de expansão, nas quais o cultivo da soja se apresenta com grandes perspectivas.

No início do cultivo da soja no Brasil a intro dução de linhagens e cultivares, seguida de seleção (geral mente entre e dentro desses materiais)constituiu-se no principal método de melhoramento adotado. VELLO (1985) relatou gue os grupos de maturação $V$ a $X$, cultivados no sul dos Estados Uni dos, são os que apresentam maiores chances de adaptação em condições subtropicais e tropicais, ressaltando que este fato tem sido muito bein explorado pelos melhoristas brasileiros. Segundo BONATO \& BONATO (1987), a fácil adaptação de 
cultivares e técnicas de cultivo oriundas do sul dos Estados Unidos, foram alguns dos principais fatores que contribuiram para a fixação e desenvolvimento da cultura no Brasil.

Com o crescimento da importância da cultura os programas de melhoramento nacionais foram se estruturando e começando a liberar seus primeiros cultivares. Por volta de 1980 dos 48 cultivares recomendados para cultivo, 26 haviam sido obtiảos de cruzamentos feitos no Brasil (KASTER \& BONATO, 1981). Geralmente, têm sido usados repetidamente os materiais melhor adaptados como parentais. HIROMOTO \& VELLO (1986) chamaram a atêção para esse fato e alertaram para a base genētica estreita desse germoplasma e mencionaram que - programa de melhoramento da soja brasileiro pode ser consi derado como um terceiro ciclo de seleção recorrente, considerando-se que doi.s parentais foram cruzados em cada geração. Diante desse quadro surge a necessidade de dentro do possivel se evitar cruzamentos entre materiajs muito aparentados e de se ampliar a base genētica do germoplasma brasileiro.

\subsection{AĞ̃O GÊNICA}

Para a implementação de um programa de melhoramento eficiente o melhorista deve ter um bom conhecimento sobre a genética da espécie con que vai trabalhar e sobre as potencialidades genēticas do material a partir do qual vai efetuar o melhoramento. Em soja, vários estudos da genētica 
de caracteres agronômicos têm sido realizados com vistas a obtenção de subsíaios para o estabelecimento de estratégias eficientes de seleção.

BRIM \& COCKERHAM (1961) através da covariância entre gerações estudaram a genética de nove caracteres de soja, entre os quais a produtividade. Com base em progênies $\mathrm{F}_{3}, \mathrm{~F}_{4}$ e $\mathrm{F}_{5}$ dos cruzamentos $\mathrm{N}$ 48-4860 x Lee e Roanoke $\mathrm{x}$ Lee, os autores avaliaram o ajustamento de seis diferentes modelos genotípicos: 1 - aditivo; 2 - dominante; 3 - epitästico aditivo x aditivo; 4 - aditivo e dominante; 5 - aditivo e espitástico aditivo x aditivo; e 6 - aditivo, dominante e epitástico aditivo x aditivo. Com exceção do modelo 2 - dominante, todos apresentaram altos coeficientes de determinação. Os resultados mostraram que os efeitos aditivos foram notoriamente mais importantes para todos os nove caracteres. Os autores :mencionaram que esses resultados fortalecem a opinião de que a dominância tem tido pouca significância evolucionāria e é de pequena importância em espécies autógamas. Relataram também que a completa ausência de efeitos gênicos de dominância é improvāvel, mas que os mesmos são de pequena magnitude comparados aos efeitos aditivos e que essa mesma conclusão pode ser tirada em relação aos ef eitos epitāsticos aditivo $x$ aditivo.

HANSON \& WEBER $(1961,1962)$, a partir de linhas homozigôticas obtidas de plantas $\mathrm{F}_{2}$ do cruzamento Adams 
x Howk eye, usaram covariância entre gerações para fazer partição da variabilidade genētica $\left(\sigma_{G}^{2}\right)$ nos componentes aditivos $\left(\sigma_{\mathrm{A}}^{2}\right)$ e epitástico aditivo $\mathrm{x}$ aditivo $\left(\sigma_{\mathrm{A} A}^{2}\right)$. Neste caso, como se admite que todos os locos estão em homozigose, não é incluída a variância devido a dominância nem a variância devido a efeitos epitástico que enyolvem dominância. Con seqüentemente, a variância genética compreende apenas as variâncias genētica aditiva e epistática aditiva x aditiva, ou seja, $\sigma_{\mathrm{G}}^{2}=\sigma_{\mathrm{A}}^{2}+\sigma_{\mathrm{A} A}^{2}$. Para os caracteres estudados, com exceção da produtividade e da porcentagem de óleo, a variância aditiva foi superior à variância epistática. As variâncias epistáticas para os caracteres altura e acamamento foram negativas. Com ex̌cieção do peso da semente e da porcentą gem de óleo, os erros das estimativas da variância epistática foram maiores que a prōpria estimativa. Eviâencia real de epistasia foi obtida para porcentagem de öleo, havendo também indicação que a epistasia pođe ser uma fonte de varia bilidade genētica para produtividade. A razão entre a variância epistātica e a genētica $\left(\sigma_{A A}^{2} / \sigma_{G}^{2}\right)$ para produtividade, maturação, peso da semente e porcentagem de óleo foram respectivamente de 0,$70 ; 0,19 ; 0,38$ e 0,52 .

HANSON et alji (1967), também a partir de cọ variância e usando linhagens homozigöticas obtidas de um dią lelo $8 \times 8$ apōs dois ciclos sucessivos de intercxuzamentos, fi zeram a partição da variância genética em aditiva e epitásti ca aditiva x aditiva. Fara a maioria dos caracteres estuda- 
dos houve predominância da variância aditiva. A razão entre a variância espitática e a variância genētica $\left(\sigma_{\mathrm{AA}}^{2} / \sigma_{\mathrm{G}}^{2}\right)$ estimada apresentou valores médios de 0,69;0,49;0,17 e 0,17, respectivamente para produção, maturidade, acamamento e altura da planta. Para mancha púrpura e mosqueamento essa relação foi respectivamente de 0,58 e 0,56. Para outros caracteres como porcentagem de proteína e óleo, essa relação foi zero ou próxima de zero, uma vez que a variância epistātica foi de pequena magnitude.

Com exceção da porcentagem de óleo, os resultados desse estudo são muito semelhantes aos apresentados por HANSON \& WEBER (1961, 1962) e confirmam a importância cảa variância epistātica para produtividade e maturidade. Com re lação à variância epistática, os trabalhos de HANSON \& WEBER (1961, 1962) e HANSON et alii (1967) chegaramaresultados di ferentes dos obtidos por BRIM \& COCKERHAM (1961) que não constataram evidências contundentes da importância da variân cia epistática aditiva $\mathrm{x}$ aditiva. Entretanto, estes autores trabalharam com material contendo um certo grau de heterozigosidade, de maneira que a presença de efeitos de dominância poderia ser a razão (ou uma das razões) para a diferença entre os resiltados obtidos.

CECON et alii (1985) utilizando o delineamento II de COMSTOCK \& ROBINSON (1948), estudaram nas gerações $\mathrm{F}_{2}$ e $\mathrm{F}_{3}$ a genética de cinco caracteres. Em ambas gerações 
constataram predominância da variância genética aditiva para os caracteres dias para a maturidade, altura da planta e núme ro de nós por planta. Para os caracteres número de vagens por planta e número de sementes por planta houve predominância da variância genética dominante en $\mathrm{F}_{2}$ e da variância adi tiva em $\mathrm{F}_{3}$. Os autores relataram que o maior número de observações realizadas em $\mathrm{F}_{3}$ parece ter melhorado a eficiência do método de estimação dos parâmetros. Por outro lado, CAMACHO (1971) através de covariâncias, a partir das gerações $\mathrm{F}_{3}$ e $\mathrm{F}_{4}$ obteve predominância da variância genética dominante păra a altura da planta no florescimento e para o período reprodu tivo.

Com base na metodologia de HAYMAN (1954b), LEFFEL \& WEISS (1958) obtiveram estimativas para a variância genētica aditiva maiores que para a variância genética dominante para os caracteres dias para o florescimento, perjodo reprodutivo, dias para a maturidade, altura da planta e tamanho da semente, na geração $F_{I}$. Para produtividade foram rea lizadas duas análises; na primeira sö foi constatada variân cia aditiva; na segunda, na qual foram excluidos e acrescentados alguns parentais em relação à primeira, a variância de vido à dominância foi maior que a aditiva. Desse modo, se evidencia que os parentais e suas progênies influiram na expressão do controle do caráter. BHATADE et alii (1977), tạn bèm em $F_{1}$, obtiveram estimativas significativas para a va- 
riância genética aditiva para os caracteres produtividade, vagens por planta, rácenos por planta e altura da planta. A estimativa da variância genētica devida à dominância não foi significativa para nenhum desses caracteres. LEFFEL \& HANSON (1961), nas gerações $\mathrm{F}_{2}$ e $\mathrm{F}_{3}$ ' para o caráter produtividade obtiveram maiores estimativas para a variância devido aos efeitos de dominância. Para outros caracteres estudados não houve consistência entre as estimativas. Entretanto, os autores relataram que a variância devido à dominância foi significativa para tamanho e qualidade da semente, maturidade; a tura e acamamento. TOLEDO \& KIIHL (1982b) obtiveram predominância da variância genética aditiva para dias para o Elores cimento e número de folhas trifoliadas.

Através dos trabalhos revisados constatou-se que nos estudos genéticos com soja, particularmente, para a ação gênica, têm sido usadas aiferentes metodologias e tambēm materiais com diferentes nivveis de homozigose. para a maioria dos caracteres tem sido constatada a ocorrência do modelo aditivo-dominante, geralmente com predominância da va riância genética aditiva. Esse é um dado muito importante para o melhoramento; primeiro, porque a média dos caracteres pouco se altera de uma geração para outra; segundo, porque a variância genética é prontamente transmitida de uma geração para outra; e terceiro, porque permite a realização de testes precoces, possibilitando a seleção em vầrios níveis de endo- 
gamia (BRIM \& COCKERHAM, 1961). Entretanto, particularmente, para produtividade, nos estudos de HANSON \& WEBER $(1961,1962)$ e HANSON et alii (1967), que trabalharam com linhagens homozigóticas, que é o estado natural das plantas autógamas, foram apresentadas fortes evidências de que a epistasia é uma importante fonte de variabilidade para esse caráter.

ST. MARTIN (1981) discutiu a importância da epistasia no melhoramento de soja considerando: a) seleção de linhagens; b) cruzamento multiparental seguido de intercruzamento; e c) seleção recorrente. Eimportante frisar que essa discussão é válida também para outras plantas autógamas. Segundo aquele autor, para seleção entre linhagens extraídas ao acaso de uma população em equilíbrio de lígação - valor genético das linhagens pode ser ajustado para o mode lo $G=u+A+A A$, onde $u$ é a média da população, A e AA representam os desvios associados aos efeitos gênicos aditivo e epistático aditivo $\mathrm{x}$ aditivo, respectivamente. Desse modo, a variância genética $\left(\sigma_{\mathrm{G}}^{2}\right)$ entre linhagens pode ser decom posta em $\sigma_{G}^{2}=\sigma_{A}^{2}+\sigma_{A A^{\prime}}^{2}$ onde $\sigma_{A}^{2}$ é a variância genética aditi va e $\sigma_{A A}^{2}$ a variância genética epistática aditiva $x$ aditiva. Portanto, partindo do conhecimento de que neste caso o coefi ciente de regressão (b) entre as progênies e o vajor genético médio dos parentais é $b=1-1 / 2 \mathrm{k}$ e que $\mathrm{k}=\sigma_{\mathrm{AA}}^{2} / \sigma_{\mathrm{G}}^{2}$ corresponde à parte da variância genética atribuida à epista sia, verifica-se que quanto maior o valor de $k$, menor seră $\circ$ de b, e por conseguinte, as progênies apresentarão 
um valor menor do que o esperado com base no diferencial de seleção empregado nos parentais. Por exemplo, tomando $k=$ 0,70 e duas linhagens produzindo 10\% acima da média da população, nas progênies do cruzamento dessas linhagens, o valor real esperado será de apenas $6,5 \%$ e não $10 \%$ acima da média da população. Em termos qualitativos a seleção entre linhagens homozigóticas atua sobre ambos os componentes aditivo e epistático, entretanto, enquanto o componente aditivo está associado a alelos o epistático é decorrente de combinações interalélicas. Estas combinações estão sujejtas a quebras e redistribuição ao acaso, não sendo necessariamente transmi tidas de maneira intacta.

Esse mesmo raciocinio Sr. MARTIN (1981) esten deu para cruzamentos multiparentais seguido de intercruzamen tos, afirmando que o nümero de gerações de intercruzamentos não tem efeito na depressão do rendimento, exceto quando os locos epistáticos são ligados. No caso da seleção recorxerte, o ganho genético esperado $(\Delta G)$ por ciclo é $\Delta G=$ $=1 / 2\left[\underline{i}(I+I) \sigma_{A}^{2} / \sigma_{p}\right]$, onde $i$ é o diferencial àe seleção estan dartizado, I é o coeficiente de endogamia dos parentajs e o $p$ é o desvio padrão fenotípico com base na média das familias. o autor chambu a atenção para o fato de que a epistasia contribui para o denominador mas não para o numerador. Desse modo, se a epistasia for um componente importante, as estimativas de ganho ge nētico baseadas na suposição de que toda a variância genētica è aditiva, poderão ser imprecisas. 
O fato é que a existência da variância epistâ tica do tipo aditivo $\mathrm{x}$ aditivo em níveis significativos, altera as estratēgias de seleção, a qual deve ser feita de modo a preservar essas interações. HANSON \& WEBER (1962) afir maram quea variância epistática envolvendo efeitos aditivos, em culturas autógamas, deve ser usada na predição do ganno genêtico dentro de uma população de linhagens homozigóticas. Afirmaram ainda que a razão da superioridade de um genótipo não é importante, desde que esse genótipo possa ser mantiảo.

\subsection{CAPACIDADE DE COMBINAGÃO}

Os melhoristas de plantas autógamas geralmente enfrentam algumas dificuldades guanảo pretendem selecio nar parentais e cruzamentos com vistas a identificax aqueles que possam produzir progênies com alto potencial de rendimen to. Os esquemas de cruzamentos dialélicos completo ou parcịal que possibilitam a estimação das capacidades geral e espe cífica de combinação têm se mostrado como uma alternativa sa tisfatöria para minimizar essas dificuldades. Mesmo em plan tas que apresentam um certo grau de dificuldade prätica para a realização de cruzamentos, como a soja, o esquema dialélico tem sido usado. GIIBERT (1958) afirmou que a análise poli gênica de um cruzamento dialëlico sofre de vários defeitos técnicos, mas em alguns casos os resultados desses defeitos não parecem ser diretamente relevantes para o melhoramento prātico. 
Os termos "capacidade geral de combinação" (CGC) \& "capacidade específica de combinação" (CEC) foram de finidos por SPRAGUE \& TATUM (1942) e têm sido usados para de signar o comportamento do material em cruzamentos. O primei ro é usado para caracterizar o comportamento médio de uma li nhagem, cultivar ou outro material genético em uma sērie de combinações hỉbridas. O segundo para caracterizar os casos nos quais certas combinações hỉbridas se apresentam relativa mente melhores ou piores do que poderia ser esperado coin base no comportamento médio dos respectivos parentais. Segundo GRIFFING (1956b) esses termos são especialmente एँteis quando se deseja avaliar e comparar o comportamento de linha gens em combinações hỉbridas.

A princípio, ess es conceitos foram desenvolvidos para plantas alógamas onđe a seleção de linhagens parentais para produção de híbridos é bastante rigorosa. Entretanto, devido ao valor prático para estudos genéticos e para a seleção de parentais de um modo geral, têm sido bastante usados em plantas autógamas.

Em soja a metodologia de análise dialélica mais utilizada é a apresentada por GRIFFING(1956b), mais pre cisamente o método 2, modelo 1 (BHATADE et alii, 1977; KAW \& MENON, 1980, 1981; SRIVASTAVA eE alii, 1978a; SRIVASTAVA et alis 1978b) e método 4, modelo I (KUNTA et alij., 1985; LEFFEL \& WEIS, 1958; SABBOUH \& EDWARDS, 1985; WEBER et alii, 
1970). No método 2 são usados os parentais e o conjunto de $\mathrm{F}_{I}$ sem recíprocos e no método 4 é usado apenas o conjunto de $\mathrm{F}_{1}$, sem parentais e sem recíprocos. No modelo 1 todos os efeitos são fixos, com exceção do exro. E importante observar que ambos esses métodos têm sido empregados tambēm em $\mathrm{F}_{2}$ (BHATADE et alii, 1977; SRIVASTAVA et aliii, 1978a; SABBOUH \& EDWARDS, 1985).

Vărios estudos têm sido feitos para avaliar a capacidade de combinação de genótipos de soja para diferentes caracteres. Entre os caracteres mais estudados estão a produtividade, número de vagens por planta, tamanho da semen te, nümero de dias para a maturidade, altura da planta na maturidade e número de dias para o florescimento. Na verdade, esses caracteres estão entre os mais importantes quando se visa o melhoramento para produção e adaptação. Invariavelmente, em todos os estudos em que esses caracteres foram incluídos, o gruadrado médio da CGC foi significativo ao nível de probabilidade de $1 \%$, tanto na geração $\mathrm{F}_{l}$ quanto na $\mathrm{F}_{2}$. Porēm, o mesmo não aconteceu com a CEC que em alguns casos foì significativa somente ao níveì de probabilidade de 5\% e em outros foi não significativa. A ünica exceção foi no trabaTho de KUNTA et ali. (1985) em que no caráter produção somen te a CEC foi significativa. De um modo geral, também em todos os caracteres mencionados, a relação entre CGC e CEC foi superior a um. Para produtividade em $F_{I}$ essa relação apresentou os seguintes valores 1,9 (KAW \& MENON, 1980), 10,4 
(PASCHAL II \& WILCOX, 1975), 1,1 (SRIVASTAVA et alii, 1978b) e 1,63 (WEBER et alii, 1970). Para $F_{2}$ os valores foram de 3,85 (BHATAADE et alii, 1977) e 1,,5 (SRIVASTAVA et alii, 1978a). Para os demais caracteres mencionados essa relação foi bem superior, apresentando em alguns casos valores maiores do que 20, como no carāter tamanho da semente (KAW \& MENON, 1980) e altura da planta na maturidade (KAW \& MENON, 1981). Como a CGC é decorrente principalmente da variância genética aditiva e da epistática aditiva $x$ aditiva e a CEC da variância genética dominante e de vários outros tipos de componentes da interação epistática (GRIFFING, 1956a; KEMPTHORNE \& CURNOW, 1961) evidencia-se que esses caracteres são controlados predominantemente por genes de efeitos aditivos. E importante observar que outros caracteres menos estudados co mo altura da planta no florescimento (BHATADE et alis, 1977; SRIVASTAVA et alii, 1978a; KAW \& MENON, 1981) leacamamento, pe so da planta, indice de colhejta e número de sementes por va gem (PASCHAL II \& WILCOX, 1975) também apresentaram relação entre CGC e CEC maior que um e, portanto, tambëm devern se enquadrar nesse tipo de controle genëtico.

PASCHAL II \& WILCOX (1975), relataram que constataram interações entre CGC e CEC com ano para vários cārac teres, já KUNTA et allii (1985) mencionaram que constataram somente interação de CGC com ano. Entretanto, PASCHAI II \& WILCOX (1975), afirmaram que embora essas interações tenham si do significativas, elas foram de pequena magnitude em rela- 
ção a CGC. Desse modo, mesmo que a CGC, que é o componente de maior interesse em soja, esteja superestimado, pelo efeito de ano, esta superestimação pode ser desprezível.

KAW \& MENON $(1980,1981)$ obtiveram correlações significativas, geralmente superiores a 0,90 , entre comportamento médio dos parentais e suas respectivas CGC para produtividade, componentes da produtividade de outros caracteres. Embora outras interpretações possam ser dadas a esses resultados, em termos práticos, a mais importante é que uma seleção preliminar para CGC poderá ser feita com base no comportamen to médio dos genōtipos. GILBERT (1.958) :afirmou que o comportamento dos parentais por si só fornece uma razoável predi-ção do comportamento relativo dos híbridos, mas que o cruzamento dialélico oferece mais informações. E acrescentou, se isto poderá ser usado para caracterizar o potencial, a Iongo prazo, de um material no começo de um programá de melhoramen to de longa duração, não se sabe.

Segundo KAW \& MENON (198I) um grande valor da CGC em relação a CEC sugere que os parentais, os quais têm um bom valor da CGC para um caráter partisular, tern maior chance de produzir progênies superiores, de modo que a predi ção de comportamento com base na CGC poderá ser geralmente válida. Entretanto, vale salientar que a CGC terá um bom poder de predição na medida em que variância epistātica aditiva $x$ aditiva for de pequena magnitude. Caso contrārio, se 
essa interação epistática for de grande magnitude, como ela está sujeita a quebras e redistribuição ao acaso, a cGC terá pouco valor de predição.

\subsection{HETEROSE E HETEROBELTIOSE}

o vigor de hỉbrido è a expressão fenotípica da heterose, a qual é um fenômeno genético, em outras palavras, heterose e vigor hỉbrido têm a mesma relação que existe entre o mecanismo e seu produto, desse modo, todos fatores que interagem com a expressão genética poderão afetar o vigor do híbrido (SINHA \& KHANNA, 1975).

o comportamento de gerações hỉbridás, ou seja, o efeito da heterose pode ser avaliado em relação a vărjọ pontos referenciais. O mais comm è a comparação com a média dos parentais, sendo essa medida chamada de "heterose". A comparação freqüentemente tambēm é feitta em relação ao parental superior, neste caso, essa medida tem sido chamada de "heterobeltiose". Outra possibilidade é comparar a geração hỉbrida com um cultivar ou híbrido comercial tomado co mo padrão. Essa medida tem sido denominada de "heterose padrão" (VIRMANT \& EDWARDS, 1983).

A soja embora sendo uma planta autógama, na qual a obtenção de sementes hỉbridas è relativamente difícil e a exploração do vigor hỉbriço è um objetivo que ainda está por ser al 
cançado, tem sido objeto de vārios estudos sobre heterose e heterobeltiose. WENTZ \& STEWART (1924) realizaram, provavel mente, um dos primeiros estudos sobre heterose em soja. Para quatro cruzamentos avaliados juntamente com os respecti vos parentais, obtiveram valores de heterose para altura de planta de $-8,70$ a $11,93 \%$, com um dos cruzamentos apresentando heterobeltiose de 7,56\%. Para produtividade por planta obtiveram heterose que variou de 59,50 a 299,85\%; todos os quatro cruzamentos apresentaram heterobeltiose para esse carāter.

VEATCH (1930), na média de 16 cruzamentos, cons tatou heterose praticamente para todos os caracteres estudados, entretanto, as maiores médias de heterose foram obtidas para produtividade por..... planta, 35,5\% número de nōs, 24,8\%, altura de planta, 15,0\% e nümero de dias para o fl.o rescimento, 7,9\%. Para esses mesmos caracteres a média da heterobeltiose foi respectivamente de 19,$5 ; \quad 8,0 ; 2,1$ e 0,6\%. O autor relatou que em soja o valor prätico da hetero se é determjrnado pela possibilidade àa mesma ser transmitida aos descendentes.

WEISS et aIii (1947) avaliaram a geração $F_{1}$ de 17 cruzamentos em casa de vegetação e em condições de cam po. Em ambas as condições obtiveram heterose e heterobeltio se para produtiviciaảe; porèn, os resultados não foram con cordantes, havendo cruzamentos que apresentaram altos valores para heterose e heterobeltiose em uma condição e baixos valores na outra condição. comparações feitas entre as médias da gexa 
ração $F_{I}$ com as mëdias de linhagens $F_{5}$ selecionadas e dos "bulks" mostraram que não houve consistência de comportamento. Esses resultados evidenciam que a heterose e a heterobeltiose não são bons critērios para predizer o potencial de um cruzamento. LEFFEL \& HANSON (1961) chegaram à conclusão semelhante. Porém, vale observar que em ambos estudos as plantas $\mathrm{F}_{1}$ foram semeadas em espaçamentos largos, ou seja, maior que o convencional, isso provavelmente influenciou os resultados.

WEBER et alii (1970) constataram heterose para produtividade, tamanho da semente, altura de planta, matu ridade e peso seco da planta. Heterobeltiose positiva foi verificada somente para produtividade. Esse estudo abrangeu vārios anos e a heterose e a heterobeltiose, para produtividade, foram relativamente consistentes atravēs dos anos, apresentando mëdias respectivamente de 25,1 e 13,4\%,

CHAUDHARY \& SINGH (1974) observaram heterose para vários caracteres; com exceção do nümero de dìas para o florescimento e do tamanho das sementes que apresentaram médias negativas (respectivamente, $-0,9$ e $-1,6 \%$ ), os demais apresentaram médias positivas; altura đe planta 39,2\%; nūmero de nōs na aste principal 24,5\%; ramos primários, 18,9\%; nב̣ mero de vagens, 55,1\%; nümero de sementes 59,9\%; sementes por vagem 0,9\%; e produçãc de sementes por planta, 57,2\%. He terobeltiose foi observada en diferentes cruzamentos para praticamente todos caracteres. Para produtividade a hetero- 
beltiose variou de $-30,3$ a $67,8 \%$, e teve uma média de $26,1 \%$. Esses autores chararam a atenção que a heterose para produtivi dade, parece estar relacionada à heterose para outros componentes da produtividade, como número de nós, número de ramos e altura da planta, que direta ou indiretamente contribuem para aumentar o número de vagens e, conseqüentemente, a produtividade da planta.

A diversidade de origem geogrāfica do material genético tem sido relatada como a chave para a diversidade genētica e conseqüentemente para heterose (PASCHAJ II \& WILCOX, 1975). Entretanto, a partir de um estudo que envol veu cruzamentos entre genōtipos de diferentes origens (China e coréia) e cultivarest melhorados nos Estados Unidos, esses au tores observaram que não existe uma relação clara entre origem geográfica e heterose. Alëm de terem obtido heterose pa ra vários caracteres, esses autores ainda verificaram que, a produtividade, a heterose e a heterobeltiose foram levemente superiores nos cruzamentos envolvendo parentais da mes ma origem $(16,4$ e 9,4\%) do que nos cruzamentos entre parentais de origens diferentes $(15,5$ e 7,0\%). O caräter peso da planta, que segundo esses autores è talvez melhor indicador de heterose do que a produtividade, apresentou resultados se melhantes a este caráter. A heterose e a heterobeltiose para parentais da mesma origem foram respectivamente de 15,1 e 7,7\% e para parentais de origem diferentes, respectivamente 14,5 e $6,4 \%$. PASCHAI II \& WIICOX (1975) explicaram que possi- 
velmente as populações das quais esses genótipos foram obtidos não estiveram suficientemente isoladas para possibilitar uma marcante divergência de biötipos.

CHAUHAN \& SINGH (1982) em um estudo de hetero se,no qual fizeram também um estudo da distância genētica en tre os parentais, obtiveram uma grande variação para as esti mativas da heterose para vārios caracteres: produtividade $(-2,3$ a $177,8 \%)$, número de vagens por planta $(-7,9$ a 143,5\%), nūmero de ramos primários $(3,7$ a $57,1 \%)$ e altura da planta $(-4,4$ a 29,8\%). Relataram que com o aumento da divergência entre parentais há um aumento da heterose atẻ um certo limite. Para produtividade, a partir desse limite, a heterose é parcialmente cancelada devido à heterose negativa em alguns de seus componentes; citaram porém, que foram observadas algumas inconsistências. Mencionaram que geralmente as progênies que exibiram maior vigor de hibrido em $F_{1}$ apresentaram maior variabilidade em $\mathrm{F}_{2}$ e que para produtiviciade a relação entre heterose e variabilidade foi evidente. Relataram ainda quea diversidade genética parece ser essencial para a manifestação da heterose, contudo, consideraram que os dados disponiveis são insuficientes para estabelecer uma cor relação definitiva entre divergência genética e heterose.

A influência do grupo de maturação na manifes tação da heterose foi estudada por CAMPos (1979), a partir de um dialelo parcial $4 \times 4$, no qual foram incluỉos dois parentais de cada um dos seguintes grupos de maturação VI, VII, 
VIII e IX. O autor constatou heterose positiva para a maioria dos caracteres estudados, porém, a heterose média, com exceção da produtividade $(19,0 \%)$, peso da planta $(15,8 \%)$, nū mero de sementes por planta $(11,1 \%)$ e número de vagens $(9,5 \circ)$ apresentou valores muito baixos. A heterobeltiose média foi negativa para a maioria dos caracteres, exceções feitas à produtividade com média de $3,3 \%$ e tamanho da semente com média de 0,6\%. O autor afirmou que a manifestação da heterose em diferentes híbridos tanto para produtividade como para os demais caracteres, mostrou--se mais dependente da capaciaade de combinação de cada parental do que do grupo de maturação.

KUNTA et aiii (1985) estudaram a manifestação da heterose em vārios caracteres obtencio os maiores valores mëdios para produtividade $(24,6 \%)$, nümero de vagens por plan ta $(18,0 \%)$, peso da planta $(19,5 \%)$ e altura da planta $(13,5 \%)$. Esses mesmos caracteres apresentaram os maiores valores para a heterobeltiose, respectivamente, 20,$1 ; 6,9 ; 14,0$ e 7,6\%. Esses autores estudaram a interação parentais $x$ anos e hïbri dos $x$ anos e constataram que os híbridos foram mais estáveis que os parentajs para produtividade e outros componentes da produtividade. Esse ë um resultado importante e apresenta-se como uma possível vantagem dos híbridos em relação à genōtipos homozigōticos äe soja.

Como muite bern afirmou VEATCH (1930), em soja, onde pelo menos a curto e possivelmente médio prazos o objetivo final do melhoramento deverá ser a obtenção de li- 
nhagens, o vigor híbrido é importante na medida em que ele pouco se altere, atravēs do processo de homozigose. MEHTA et alii (1984) estudaram o comportamento da produtividade de 12 cruzamentos de soja nas gerações $\mathrm{F}_{1}, \mathrm{~F}_{2}$ e $\mathrm{F}_{3}$." Constataram heterose e heterobeltiose significativas em vārios cruzamentos, obtendo para esses parâmetros médias, respectivamente de 90,0 e 57,8\%. Nas gerações $F_{2}$ e $F_{3}$ obtiveram uma mëdia de depressão por endogamia de 24,1 e $30,2 \%$. Houve uma grande variação entre cruzamentos quanto a heterose, heterobel tiose e depressão por endogamia, porém, a maioria dos cruzamentos que apresentaram heterose e heterobeltiose significativas apresentaram também perdas significativas por endogamia em $\mathrm{F}_{2}$ e $\mathrm{F}_{3}$. Esses resultados mostram que o efeito heterötico em grande parte deveu-se à ação gênica. não-aditiva. Contudo, houve alguns cruzamentos que, mesmo com perdas isignificativas por endogamia, apresentaram em $\mathrm{F}_{3}$ mëdias aproxima damente iguais ou um pouco superior ao parental mais produti vo. Esse é um resultado importante porque, dependendo da magnitude da variância genëtica desses cruzamentos em $\mathrm{F}_{3}$ ' po de haver possibilidade de serem obtidas linahgens superiores ao parental mais produtivo.

A. partir dessa revisão constatou-se que a soja apresenta heterose e heterobeltiose para produtividade, componentes da pxodutividade e vários outros caracteres ầgronômicos. Constatou-se também que a heterose pela própria natureza da ação gênica não-aditiva, da qual ela decorre, tem um 
valor limitado para o melhoramento da soja. Por outro lado, se evidencia que o uso do vigor de híbrido tem potencial pa ra promover um considerável aumento na produtividade da soja, estando sua exploração comercial na dependência do desen volvimento de um método econômico para produção de sementes híbridas em larga escala; a este respeito, a dispersão ineficiente do pólen parece ser o principal fator limitante.

\subsection{Correlacão entre caracteres}

A correlação reflete o grau de associação entre caracteres. Seu conhecimento pelo melhorista é importan te porque mostra como a seleção para um caráter infiuencia a expressão de outros caracteres. Nos programas de melhoramento, geralmente, além de se visar o aprimoramento de um carāter principal busca-se tambēm manter ou melhorar a expressão de outros caracteres.

A correlação entre caracteres tem duas causas principais, uma genētica e outra de ambiente. As causas genéticas são principalmente a pleiotropia e a ligação gênica; essa ligação causa correlações passageiras, particularmente quando as populações são derivadas de parentais divergentes. A correlação de ambiente entre caracteres ocorre quando os mesmos são influenciados pelas mesmas difexenças de condições do ambiente (FALCONER, 1960). 
A correlação pode ser estimada em três níveis fenotípico, genotípico e de ambiente. No nível fenotípico estão envolvidas tanto as causas genéticas como as de ambiente. VENCOVSKY (1978) chamou atenção para o fato de que a correlação fenotípica é o que se observa no campo e a genotípica è a que mede realmente a associação genética entre os caracteres. JOHNSON et alii (1955b) mencionaram que as correlações genotí picas e fenotípicas são üteis no planejamento e avaliações en programas de melhoramento, podendo facilitar a interpretação de resultados e contribuir para a estruturação de programas mais eficientes.

Em soja tem sido realizado um grande número de estudos sobre correlação de caracteres, notadamente entre aqueles de valor agronômico. Os estudos em sua maioria referem-se às correlações genotípicas e ou fenotípicas. Nos trabalhos em que foram estimadas as correlações genotípicas e fenotípicas constata-se que geralmente elas têm o mesmo si nal e que, com poucas exceções, as correlações genotípicas são maiores que as fenotipicas (ANAND \& TORRIE, 1963; BYTH et alii, 1969; CAVINESS \& PRONGSIRIVATHANA, 1968; FEHR \& WEBER, 1968; JOHNSON et alii, 1955b; KNOW \& TORRIE, 1964; SNITH \& WEBER, ..1968).

Para produtividade têm sido obtidas estimativas de correlação posjtiva com número de vagens por planta, 
número de sementes por vagem (ANAND \& TORRIE, 1967; CAMPOS, 1979; JOHNSON et alii, 1955b; PANDEY \& TORRIE, 1973), nūmero de dias para a maturidade (ANAND \& TORRIE, 1963; HARRISON et alii, 1981; JOHNSON et alii, 1955b; KNOW \& TORRIE, 1964; SIMP SOM \& WILCOX, 1983). e período de frutificação (ANAND \& TORRIE, 1963; BYTH et alii, 1969; JOHNSON et alii, 1955b; KNOW \& TORRIE, 1964 ).

Nas correlações da produtividade com acamamento, al tura da planta e número de dias para o florescimento, embora predominando as estimativas positivas (ANAND \& TORRIE, 1963; KNOW \& TORRIE, 1964 e SIMPSON \& WILCOX, 1983), têm sido obtidos também estimativas negativas (BYTH et alii, 1969; JOHNSON et aIii, 1955 b).

As correlações da produtividade com o peso de cem sementes apresentaram uma ampla variação, tanto em magnitude como em direção (ANAND \& TORRIE, 1963; HARRISON et alii, 1981; JOHNSON et alii, 19556).

Para o caráter número de vagens por planta ANAND \& TORRIE (1963) obtiveram correlações negativas com - número de sementes por vagen e peso de cem sementes, resultados que estão em acordo com os obtidos por JOHNSON et alii, (1955ḅ). Obtivecam tambēm correlações positivas desse caráter com número de dias para o florescimento, número de dias para a maturidade, acamamento e período de frutificação. Por outro lado, JoHnSON et alii (1955b) correlacionando o número 
de vagens por planta com esses mesmos caracteres obtiveram correlação positiva somente com acamamento.

Para o número de sementes por vagem as correlações com peso de cem sementes, nūmero de dias para floresci mento, maturidade, altura da planta, acamamento e frutificação obtidas por ANAND \& TORRIE (1963) foram predominantemente negativas. Já JOHNSON et alii (1955b)obtiveram correlações positivas desse carāter com nümero de dias para o florescimento, altura e acamamento.

No carāter peso de cem sementes as estimativas de correlação com a maioria dos caracteres mencionados foi negativa, exceção feita ao nümero de dias para a maturidade (JOHNSON et alii, 1955b; KNOW \& TORRIE, 1964).

As porcentagens de óleo e proteina que são dois caracteres da maior importância em soja, com raras exce ções, apresentaram correlações negativas ou prōximas de zero com a maioria dos caracteres (JOHNSON et alii, 1955b; KNOW \& TORRIE, 1964; SIMPSON \& WEBER, 1983; SIMTH \& WEBER, 1968; FEHR \& WEBER, 1968). As correlações entre ôleo e proteína obtidas por vários autores têm sido invarjavelmente negativas (GUPTA et alii; JOHNSON et alii, 1955b; KNOW \& TORRIE, 1964: SIMPSON \& WILCOX, 1983). 
Em soja, com raras exceções, se observa uma grande variação entre as estimativas de correlação entre ca racteres, em direção e principalmente em magnitude, entre trabalhos diferentes e em um mesmo trabalho entre cruzamentos ou populações diferentes. Esse é um fato importante por que mostra que o grau de associação entre caracteres pode ser bastante diferente de uma população para outra. Evidentemente que com o acúmulo de estimativas se obtém uma indica ção de direção predominante da correlação e do nỉvel de assó ciação entre os caracteres, o que se constitui um subsidio importante para o melhorista. Entretanto, o que parece razoável é que para populações que deverão ser trabalhadas por médio a longo prazos, para que o melhorista tenha maior eficiência no processo de seleção, as correlações devem ser estimadas na: própria população sob melhoramento.

\subsection{ESQUEMAS DE CRUZAMENTO}

Em plantas autógamas há um certo consenso de que o cruzamento biparental tem sido o esquema mais usado para a obtenção de variabilidade (FREY, 1976). Entretanto, o que os melhoristas têm feito cruzando ano após ano os cultivares melhorados entre si, é um prosesso de seleção recorrente a longo prazo, a partir de cruzamentos biparentais. O melhoramento da soja no Brasil è um exemplo disso. Atualmente, se considera que os materiais brasileiros correspon- 
dem ao terceiro ciclo de seleção recorrente em relação aos primeiros cultivares melhorados (HIROMOTO \& VELLO, 1986).

FREY (1976), afirmou que as recombinações pos siveis a partir de cruzamentos biparentais são bastante restritas para permitir um rápido progresso em espécies autógamas. Vārios autores têm apresentado esquemas alternativos de cruzamento para aumentar a variabilidade inicial disponivel para práa tica de seleção. Harlan $(1940)^{1}$ citado por FREY (1976) propôs um esquema de cruzamentos múltiplos e Mackey (1954)2, também cìtado por FREY (1976), apresentou um esquema modificado de re-trocruzamentos.

JENSEN (1970), apresentou um esquema de cruza-mento bastante flexivel com várias alternativas a serem seguidas em função do número e do tipo de parentais a serem usados. Segundo o autor esse esquema constitui-se em um suple-mento aos métodos convencionais de melhoramento de plantas autógamas. Nele é possível a formação de uma ou mais popula ções hỉbridas a partir de cruzamentos envolvendo vārios parentais.

1 HARLAN, H.V.; MARTINI, M.L.; STEVENS, H. A study of methods in barley breeding. USDA. Technical Bulletin, Washington, $\underline{720}: 1-26,1940$.

2 MACKEY, J. Breeding of oats. Habnbuch für Pflanzenzüchtung, 2: 512-17, 1954 . 
STUBER (1980), relacionou: uma série de alterna tivas para obtenção de variabilidade como cruzamento biparen tal, triplo, duplo, múltiplo, retrocruzamento, cruzamentos dialélicos e cruzamentos em cadeia, que são aplicáveis a espécies autógamas.

A formação da população básica em plantas autógamas é geralmente uma etapa relativamente difîcil: primeiro porque para um mesmo número de parentais não hă informações sobre a eficiência dos diferentes esquemas de cruzamento para liberação de variabilidade; e segundo porque o melhorista, para atender a seus,objetivos, geralmente se defronta com a necessidade de realizar um grande número de cruzamentos.

Em soja alternativamente ao cruzamento biparental simples vários autores têm ùsado diferentes esquemas para obtenção de variabilidade, como os seguintes: dialelo parcial seguido de cruzamento duplo e cruzamento planta a planta (SUMARNO, 198I); retrocruzamento seguido de intercruzamento (KENWOORTHY \& BRIM, 1979); cruzamento biparental seguido de cruzamento dialélico entre os $F_{1}$, formação de "bulk" e cruzamento planta a planta (MILLER \& FEHR, 1979); cruzamento dialélico e intercruzamento entre os $F_{1}$ (WALKER \& SCHMITTHENNER, 1984); e cruzamento biparental seguido de cru zamento duplo, formação de "bulk" e cruzamento planta a plan ta (PROHASKA \& FEHR, 1981). 
Para soja um método de obtenção de variabilidade genética é eficiente quando atende a dois objetivos, si multaneamente; facilidade de obtenção de gerações segregan tes, traduzido pela redução do número de cruzamentos a um nivel minimo; e produção de variabilidade em um nível suficiente para permitir progressos genéticos significativos com a seleção. Esse segundo item é muito importante para progra mas que envolvem seleção recorrente e que têm objetivos a mé dio e longo prazos.

$$
\text { Em soja, que è uma cultura que tem um alto }
$$

nivel de melhoramento, na qual omaterial melhorado tem uma base genética relativamente estreitâ, particularmente o germoplasma cultivado no continente americano, é importante que se busquem alternativas que minimizem os problemas com patamares de produtividade e com vulnerabilidade genētica do ger moplasma. 


\section{MATERIAL E MÉTODOS}

\subsection{Material genético}

Foram usados dez genōtipos de soja (Glycine $\max ($ L.) Merrill), reunindo cultivares comerciais e linhagens experimentais. Todos os genōtipos fazem parte da coleção do Setor de Genētica Aplicada às Espécies Autógamas do Instituto de Genética da Escola Superior de Agricultura "Luiz de Quej. roz", da Universidade de são Paulo e foram deliberadamente escolhidos para esse estudo. Os critérios utilizados na escolha foram basicamente os seguintes: precocidade, poucos ou nenhum ancestral comurn e valor agronômico, avaliado através do aspecto geral de cada genōtipo. Na Tabela 1, são apresen tadas algumas características desses genötipos.

\subsection{CARACTERIZAEÃO DO AMBIENTE}

Os trabalhos experimentais foram realizados no município de Piracicaba-SP, que situa-se a $22^{\circ} 42^{\prime} 30^{\prime \prime}$ de latitude sul, $47^{\circ} 38^{\prime} 00^{\prime \prime}$ de longitude oeste e a uma altitude de $537 \mathrm{~m}$ acina do níveí do mar. O experimento foi conduzido em ārea experimental do Departamento de Genética da ESALQ, 
em solo do tipo terra roxa estruturada-série "Luiz de Queiroz" (RANZANI et alii, 1966). As condições meteorológicas do período em que o experimento de campo foi realizado, referentes a precipitação pluvial, temperatura e umidade relativa são apresentadas na Figura 1 .

\subsection{Procedimentos experimentais}

\subsubsection{Obtenção de sementes $F_{1}$}

Todos os cruzamentos possiveis entre os dez (n) parentais, com exceção dos recíprocos, num total de $[\underline{n}(n-1) / 2]=45$ foram realizados ao nivel de campo no segundo semestre de 1985. Para a realização dos cruzamentos o grupo de parentais foi semeado quatro vezes, com um intervalo de uma semana entre as semeaduras. Com isso visou-se fazer coincidir o florescimento daqueles parentais que apresentavam maiores diferenças entre o número de dias para o início do florescimento e também possibilitar a disponibilidade de flores para cruzamento por um período mais longo.

Os cruzamentos foram realizados geralmente pe la manhã e algumas vezes no final da tarde. Para a realização do cruzamento, no parental feminino, usaram-se botões flo 
rais que deveriam abrir no dia seguinte, extraindo-se as pétalas com uma pinça de modo a expor o estigma, não se fazendo emasculação. No parental masculino colheram-se flores já abertas das quais se extraiu o estigma impregnado de pólen, o qual em seguida foi levemente friccionado sobre o estigma da flor do parental feminino, resultando na : polinização controlada. Após essa etapa, fez-se a identificação do crü zamento com uma etiqueta que continha o código do cruzamento, localização relativa da flor na planta, o número de flores polinizadas na inflorescência, data do cruzamento e geralmen te as letras iniciais do nome da pessoa que efetuou o cruzamento.

As vagens oriundas dos cruzamentos foram colhidas individualmente à proporção em que iam atingindo a ma ¿turidade, completando-se a secagem à sombra. $0 \ldots$ pegamento foi aproximadamente de $8 \%$

\section{$3 \cdot 3.2$. Obtenção de sementes $\mathrm{F}_{2}$}

A semeadura das progênies $F_{I}$ foi realizada em copos plásticos e em torno de oito dias após a emergência as plântulas foram transplantadas para o campo.

Como nos cruzamentos não foi feita emasculação, houve a possibilidade de ocorrer autofecundação. Para evitar a inclusão de autofecundações indesejāveis entre os híbridos, as vagens foram mantidas separadas em cada cruza- 
mento e as plantas $F_{1}$ de cada vagem individual foram observa das quanto à expressão de genes marcadores como cor da flor, hábito de crescimento, cor da pubescência, cor da vagem e em alguns casos cor do hilo. As plantas nas quais o gene marca dor do cruzamento não se expressou foram descartadas.

As plantas $F_{1}$ foram colhidas individualmente e com as sementes $\mathrm{F}_{2}$ obtidas foi preparado o experimento para a coleta dos dados experimentais.

\subsubsection{Delineamento e características do experimento}

Foi usado o delineamento ein reticulados quadra dos (lattice), a seguir denominado látice, 8 × 8 com seis repẹ tições. Os 64 tratamerıtos foram constituídos por dez parentais, 45 progênies $F_{2}$ e nove progênies $F_{2}$ adicionais.

A parcela foi representada por uma fileira com $5 \mathrm{~m}$ de comprimento. O espaçamento entre fileiras foi de 1,0 m e foram semeadas :en torno de 15 sementes por metro linear de. sulco. Aos 25 dias ..pós-semeadura foi realizado um desbaste para dez plantas por metro linear.

A primeira e segunda repetições foram semeadas em 20/10, a terceira e quarta em 28/10 e a quinta e sexta em 05/13/86. Esse escalonamento de semeadura teve dois objetivos, reduzir o risco de que alguma intempërie com 
prometesse igualmente todo o experimento e evitar um grande acúmulo de trabalho por ocasião da coleta de dados.

Na semeadura foi feita uma adubação aplicando-se 25g da mistura NPK 0-30-10, por metro linear no sulco de plantio e as sementes foram inoculadas com uma mistura das estirpes de Rhizobium japonicum C-99 (SEMIA-587) e C-147 (SEMIA-5019) obtidas no Laboratório de Microbiologia do Solo do Centro de Energia Nuclear na Agricultura (CENA) .

\subsubsection{Caracteres avaliados}

Logo após o desbaste, quando as plantas ainda apresentavam-se bastante uniformes, foram etiquetadas seis plantas nas parcelas dos parentais e doze plantas nas parcelas das progênies $\mathrm{F}_{2}$. As etiquetas foram distribuídas ao acaso, procurando-se sempre amostrar somente plantas competi tivas en toda a extensão da parcela. Com exceção da produtividade da parcela, as denais observações foram realizadas nas plantas individuais etiquetadas. Foram coletados dados dos seguintes caracteres:

$$
\begin{aligned}
\text { NDF - } & \text { número de dias para o início do florescimento. } \\
& \text { Contados da semeadura até a antese da primeira } \\
& \text { flor. } \\
\text { NIF - } & \text { número de internódios na aste principal no } \\
& \text { início do florescimento. Contados desde o nó } \\
& \text { cotiledonar até o ápice da aste principal. }
\end{aligned}
$$


APF - altura da planta (cm) no inicio do florescimen to. Medida desde a base até o ápice. da aste principal.

NDM - número de dias para a maturidade. Contados des de a semeadura até aproximadamente 95영 vagens apresentarem-se maturas.

NIM - número de internódios na maturidade. Contados desde o nó cotiledonar até o ápice da aste principal.

APM - altura da planta (cm) na maturidade. Medida desde a base da planta até o ápice da , aste principal.

AC - acamamento, avaliado na maturidade. Para esse carāter foi usada una escala variando de. 1 a 5 , onde a nota 1 correspondeu a uma planta ereta e a nota 5 a uma planta completamente acamada.

VA - valor agronômico, avaliađo na maturidade. Nesse caráter foi usada uma escala de 0 a 5 , onde a nota zero correspondeu a uma planta sem nenhum valor agronômico e nota 5 a uma planta com excelentes características agronômicas (grande nümero de vagens, sem acamamento, ausência de hastes verdes, sem debulha de vagens, sem sintomas de doenças).

PPI - produtividade de planta individual, avaliada na maturidade atravēs do peso dos grãos das plantas individuais amostradas (etiquetadas) na parcela. A unidade usada foi gramas por planta. 
PP - produtividade da parcela, avaliada na maturida-. de. Obtida pela soma cos pesos de grãos das plantas avaliadas individualmente e do restante da parcela, colhido e trilhado em massa ("bulk"). Foi excluida uma planta em cada extremidade da parcela (com bordadura terminal).

Na avaliação da produtividade, tanto de plantas individuais como da parcela, após a colheita foi feita uma complementação da secagem à sombra antes do beneficiamen to. Uma nova uniformização de secagem foi feita após o bene ficiamento: todo o material foi exposto ao sol por dois dias e recolhido ao laboratório, esperando-se três dias para iní cio das pesagens.

\subsection{ANALISES ESTATISTICO-GENÉTICAS}

Com exceção da produtividade da parcela, as análises dos caracteres foram realizadas com base na média das observações feitas em plantas individuais. Nos caracteres número de internödios no florescimento e na maturidade, acamamento e valor agronômico, as anälises foram realizadas com os dados transformados para $\sqrt{\mathrm{x}+1}$.

\subsubsection{Análise de variância}

Foram realizadas duas análises de variância, uma no esquema látice e outra em blocos completos casualizados. 
A análise em blocos casualizados obedeceu ao seguinte modelo linear (MIRANDA, 1987; SINGH \& CHAUDHARY, 1979; TOLEDO \& KIIHL, 1982b):

$$
Y_{i j k}=u+T_{i j}+B_{k}+e_{i j k}
$$

sendo:

$$
\begin{aligned}
& Y_{i j k}=\text { observação colhida no ixj-ésimo tratamento no } \\
& k \text {-ésimo bloco ( } i \text { e j, neste caso, são os parentais do } \\
& \text { cruzamento) } \\
& \mu=\text { média geral de todos os tratamentos; } \\
& \mathrm{T}_{i j}=\text { efeito do ixj-ésimo tratamento; } \\
& B_{k}=\text { efeito do k-ésimo bloco; } \\
& e_{i j k}=\text { efeito do erro experimental, o qual é normal e } \\
& \text { indenpendentemente distribuído com média zero e } \\
& \text { variância } \sigma_{\mathrm{e}}^{2} \text {. } \\
& i, j=1,2,3, \ldots, 10 \text {, corresponde aos pa- } \\
& \text { rentais } \\
& i x j-\operatorname{para} i=j \text { corresponde ao efeito de um } \\
& \text { genótipo parental } \\
& i x j-\operatorname{para} i \neq j \text { corresponde ao ef ei to de uma pro- } \\
& \text { gênie } F_{2} \text { obtida do cruzamento entre os pa } \\
& \text { rentais i e j. }
\end{aligned}
$$

Na anâlise de blocos casualizados, para se ve rificar a necessidade de um teste mais preciso realizou-se o teste de Bartlett para avaliar a homogeneidade das variâncias residuais (STEEL \& TORRIE, 1980). Para isso fez-se a decomposição da soma de quadrados de grupos (parentais mais progênies $\mathrm{F}_{2}$ ) e resíduo em seus respectivos componentes (Ta- 
bela 2). Dessa maneira, quando houve homogeneidade entre as variâncias residuais o teste "F" foi realizado usando-se o resíduo geral $\left(\mathrm{QM}_{4}\right)$ e quando não houve homogeneidade cada fonte de variação foi testada com seu respectivo resíduo. As comparações entre as médias dos parentais e entre as médias das progênies $F_{2}$ foram feitas usando-se o teste de Tukey ao nĩvel de probabilidade de 5\%

\subsubsection{Análise de coxrelações}

As correlações entre os dez caracteres foram estimadas separadamente para os parentais que constituem um grupo de genótipos homozigóticos e para as 45 progênies $F_{2}$ que constituem um grupo com uma média de somente 50 o dos locos "em homozigose. Para cada grupo foram estimadas as correjações fenotípicas $\left(r_{F}\right)$ genotipicas $\left(r_{G}\right)$ e de ambiente $\left(r_{E}\right)$.

No cālculo das correlações roi usada a relação apresentada por KEMPTHORINE (1969), a qual è a seguinte:

$$
V(x+y)=V(x)+V(y)+2 \operatorname{Cov}(x y)
$$

de modo que:

$$
\operatorname{Cov}(x y)=\frac{V(x+y)-V(x)-V(y)}{2}
$$

onde se tem que:

$$
\begin{aligned}
\mathrm{V}(\mathrm{x}) & =\text { variância do carāter } \mathrm{x} ; \\
\mathrm{V}(\mathrm{y}) & =\text { variância do caräter } \mathrm{y} ; \\
\mathrm{V}(\mathrm{x}+\mathrm{y}) & =\text { variância da soma dos caractexes } \mathrm{x} \text { e } \mathrm{y} ; \\
\text { Cov }(\mathrm{xy}) & =\text { covariância entre os caracteres } \mathrm{x} \text { e } \mathrm{y} .
\end{aligned}
$$


Para a obtenção desses parâmetros fez-se a análise da variância dos caracteres $x$ e $y$ individualmente e da soma desses caracteres $(x+y)$. A partir dessas análises e utilizando a relação apresentada por KEMPTHORNE (1969) foram estimadas as covariâncias ou produtos médios para os pares de caracteres ( $x, y)$ (Tabela 3 ): Usando a nomenclatura dessa Tabela tem-se que:

$$
P M(x y)=\frac{Q M(x+y)-Q M x-Q M y}{2}
$$

A partir dos quadrados médios (variâncias) e ãos produtos mëdios (covariâncias) foram estimadas as correla ções atravēs das seguintes fórmulas:

Correlação fenotípica $\left(r_{F}\right)$ :

$$
r_{F}=\frac{\operatorname{PMT}(x y)}{(\text { QMTX } \cdot \text { QMTY })^{0,5}}
$$

Coræelação genotỉpica $\left(r_{G}\right)$ :

$$
r_{G}=\frac{\dot{\phi}_{g}(x y)}{\left(\phi_{g(x)}^{2} \cdot \phi_{g(y)}^{2}\right)^{0,5}}
$$

onde:

$$
\begin{aligned}
& \phi_{g(x y)}=\frac{\operatorname{PMT}(x y)-\operatorname{PME}(x y)}{b} ; \\
& \phi_{g(x)}^{2}=\frac{\operatorname{QMT}(x)-\operatorname{QME}(x)}{b} ; e \\
& \phi_{g(y)}^{2}=\frac{\operatorname{QMT}(\underline{y})-\operatorname{QME}(y)}{b}
\end{aligned}
$$


Correlação de ambiente $\left(r_{E}\right):$

$$
r_{E}=\frac{\operatorname{PME}(x y)}{[\operatorname{PME}(x) \cdot \operatorname{PME}(y)]^{0,5}}
$$

\subsubsection{Anālise dialêlica}

Como no estudo não foram realizados os cruzamentos reciprocos, as anälises foram baseadas em meia tabela dialëlica (Tabela 4).

\subsubsection{Análise de HAYMAN (1958)}

As bases teóricas para essa anälise foram desenvolvidas inicialmente para a geração $F_{1}$ (HAYMAN, 1954a, b e JINKS, 1954) e posteriormente para a gerą̧ão $F_{2}$ (HAYMAN, 1958 e JINKS, 1956). A aplicação dessa metodologia se baseia nas seguintes suposições:
a) segregação àiplöide;
b) ausência de efeitos recíproces entre cruzamentos;
c) ação indepenảente de genes não alëlicos, ou seja, ausência de epistasia:
d) ausência de alelos múltiplos;
e) Iinhagens parentais homozigóticas;
f) genes independentemente distribuidos nos parentais.

A segregação diplöide e uma caracteristica normal da espécie. Os demais requisitos também devem ser razoavelmente atendidos. Contudo, no que se refere à ausên- 
cia de alelos múltiplos e, particularmente, a ausência de epistasia é provável que haja alguns desvios. A soja ë uma espécie na qual a epistasia tem sido relatada como um componente genētico importante (HANSON \& WEBER, 1961, 1962 e HANSON et alii, 1967). Entretanto, o próprio modelo testa a significância desses desvios e só deve ser aplicado quando os mesmos não forem significativos.

A partir da tabela dialélica (Tabela $\hat{4}$ ) foram calculadas as seguintes variâncias e covariâncias:

$V_{O L O}=V_{p}=$ variância dos genötipos parentais, $\left.v_{p}=\frac{1}{n-1}\left[\sum_{i=1}^{n} Y_{i j}^{2}-\sum_{i=1}^{n} Y_{i j}\right)^{2 / n}\right]$, para $i=j ;$

$V_{\text {Irl2 }}=V_{i}=$ variância da i-ësima linha da tabela dialélica, ou seja, variâncì da progênie da linha do parental i, o qual tambëm è incluído no călculo,

$\left.v_{i}=\frac{1}{n-1}\left[\sum_{i=1}^{n} x_{i j}^{2}-\sum_{i=1}^{n} x_{j j}\right)^{2 / n}\right]$, para $i \leq j ;$

$V_{I L 2}=\bar{\nabla}_{i}=$ média das varianncias das Iinhas da tabela dialélica, ou seja, média das variâncias das progênies dos $n$ parentais recorrentes. 
$\bar{v}_{i}=\frac{1}{n} \sum_{i=1}^{n} v_{i}$

$\begin{aligned} & v_{\text {OL2 }}=\mathrm{V}_{\bar{i}}= \text { variância das médias das linhas da tabela dialé- } \\ & \text { lica, ou seja, variância das médias das progê- }\end{aligned}$ nies dos $\mathrm{n}$ parentais recorrentes.

$\left.v_{\bar{i}}=\frac{1}{n-1}\left[\sum_{i=1}^{n} \bar{y}_{i}^{2}-\sum_{i=1}^{n} \bar{Y}_{i .}\right)^{2 / n}\right]$

$\mathrm{W}_{\text {olrL2 }}=\mathrm{C}_{i}=$ covariância entre as progênies da $i$-ésima linha com os respectivos parentais não recorrentes,

$\left.c_{i}=\frac{1}{n-1}\left[\sum_{j=1}^{n} Y_{i j} Y_{j j}-\sum_{j=1}^{n} Y_{i j}\right)\left(\sum_{j=1}^{n} Y_{j j}\right) / n\right] ;$

$W_{\text {OLO2 }}=\bar{C}_{i}=$ mêdia das covariâncias entre progênies da i-ési. ma linha com os xespectivos parentais. não recor rentes,

$\bar{c}_{i}=\frac{1}{n} \sum_{i=1}^{n} c_{i}$

$\left(M_{2}-M L_{0}\right)^{2}=$ quadrado da diferença entre a média das progênies $F_{2}\left(M L_{2}\right)$ e a média dos $n$ parentais (ML ${ }_{0}$;

$\left(M_{2}-M L_{0}\right)^{2}=\left(\frac{2}{n(n-1)} \sum_{i=1}^{n} x_{i j}-\frac{1}{n} \sum_{i=1}^{n} x_{j i}\right)^{2}$, para $i<j ;$ 
nessas condições tem-se que:

$Y_{i j}=Y_{j j}=T_{i j}$ para $i=, j$ no caso dos parentais; e

$\bar{Y}_{i .}=\frac{1}{n} \sum_{i=1}^{n} Y_{i j}$ para a $i$-ésima linha.

A partir dessas variâncias e covariâncias como sugeriram ASKEL \& JOHNSON (1953), JINKS (1954) e TOLEDO \& KIIHL (1982b), primeiro foi realizada a anảlise gráfica de acordo com HAYMAN (1954b) e SINGH \& SINGH (1984a), a qual possibilita uma visualização genētica relativa dos parentais. Essa análise é realizada com base na regressão de $C_{i}$ sobre $V_{i}$, a qual permite o estabelecimento da seguinte equação:

$$
c_{i}=a+b v_{i} \quad(a=\underset{g r a ̈ f i c a)}{A \text { na representação }}
$$

e na parābola limitante obtida atravès da seguinte equação:

$$
c_{i}^{2}=v_{p} \cdot v_{i}
$$

Sendo a o ponto de interseção da reta com o eizo das ordenadas e b coeficiente de regressão linear, os quais são obti dos através das fórmulas:

$$
\begin{aligned}
& b=\frac{\operatorname{Cov}\left(C_{i}, V_{i}\right)}{\operatorname{Var}\left(V_{i}\right)} \\
& a=\bar{c}_{i}-b \bar{v}_{i}
\end{aligned}
$$

- erro de b foi estimado segundo SINGH \& CHAUDHARY atravès da seguinte förmula: 


$$
s_{b}=\left[\frac{\operatorname{Var} c_{i}-b \operatorname{Cov}\left(c_{i}, v_{i}\right)}{(n-2) \operatorname{Var} v_{i}}\right]^{0,5}
$$

Os testes de significância de b em relação a zero (hipōtese $0: \mathbf{b}=0$ ) e em relação a unidade (hipótese $1: \mathbf{b}=1)$ foram realizados através do teste "t", ao nível de probabilidade. de 5\% e com $n-2$ graus de liberdade.

MATHER \& JINKINS (1982) ralataram que o gräfico de $C_{i}$ sobre $V_{i}$ possibilita informações sobre três pontos: primeiro, fornece um teste de suficiência do modelo, uma vez que na ausência de interações não àlêlicas e com àstribui ção independente dos genes entre os parentais, $c_{i}$ e relacio nado a $V_{i}$ por uma reta de regxessão com inclinação próxima da unidade; segundo, permite uma estimativa de grau médio de dominância a partir das medidas, em relação à origem (o), das distâncias entre os pontos onde a reta de regressäo e a reta tangente à parábola interceptam o eixo das ordenadas $\left(\mathrm{C}_{1}\right)$, respectivamente pontos $A_{\text {e }} B_{i}$ e terceiro, os pontos $C_{i}: V_{i}$ ao Iongo da reta de regressão fornecem uma meäida da cijstribuj ção dos genes dominantes e recessivos entre os parentais. Mais pröximos da origem estão os parentais com maior numero de genes dominantes e mais na extremidade da reta os parentais com maior numero de genes recessivos.

Na Figura 2, é apresentado um grä́fico teörico

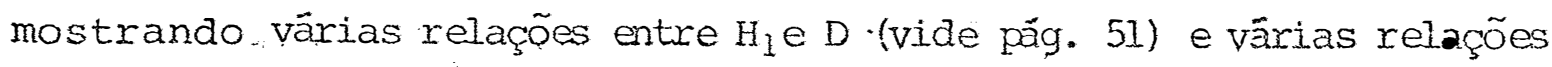


entre freqüèncias de genes dominantes e recessivos nos parentais.

Para a geração $F_{I} \overline{\mathrm{AB}} / \overline{\mathrm{OB}}=\mathrm{H}_{1} / \mathrm{D}$ (HAYMAN, 1954b), para a geração $F_{2}$, após uma geração de autofecundação essa relação é alterada. SINGH \& SINGH (1984a) relataram que para $F_{2} \overline{\mathrm{AB}} / \overline{\mathrm{OB}}=\left(\mathrm{H}_{1} / 16\right) /(\mathrm{D} / 4)=\mathrm{H}_{1} / 4 \mathrm{D}$, de modo que o grau mëdio de dominância (grid) estimado em $F_{2}$ correspondente à metade do estima do em $F_{1}$. Sendo assim, o grau médio de dominância . a partir de dados da geração $F_{2}$ deve ser multiplicado por dois para ser expresso ao nível de $F_{I}$ e é fornecido pela fórmula: gîd $=2[\overline{\mathrm{A}} \overline{\mathrm{B}} / \overline{\mathrm{OB}}]^{0.5}$.

Desse modo em $F_{2}$ podem surgir as seguintes $r \underline{e}$ lações de dominânđia:

$$
\begin{aligned}
& 4 \overline{\mathrm{AB}}=0 \text {, indica ausência de dominância } \\
& 4 \overline{\mathrm{AB}}<\overline{\mathrm{OB}}, \text { indica dominância parcial } \\
& 4 \overline{\mathrm{AB}}=\overline{\mathrm{OB}}, \text { indica dominância completa } \\
& 4 \overline{\mathrm{A} B}>\overline{\mathrm{OB}}, \text { indica sobreảiminância }
\end{aligned}
$$

Apōs a anālise gráfica fez-seuma anālise: numérica do. cruzamento dialélíco. De acordo com HAYMAN (1958), MATHER \& JINKS (1982), SANTOS (1984) e SINGH \& SINGH (1984b) foram estabelecidas as equações para o cálculo das estimativas dos parâmetros $\mathrm{D}, \dot{\mathrm{F}}, \mathrm{H}_{1} \mathrm{e} \mathrm{H}_{2}$ (vi.ae pāg. 5l). 
tendo-se que:

$\hat{\mathrm{D}}=$ : estimativa do componente de variância deviaos efeitos gênicos aditivos;

$\hat{\mathrm{F}}=$ estimativa do componente genético correspon dente à covariância entre os efeitos aditivos e dominates dos genes. Indica a freqüência relativa dos alelos dominantes e recessivos na po pulação parental. F será positivo se os alelos dominantes tiverem maior freqüência que os recessivos e será negativo se ocorrer o contrārio;

$\hat{\mathrm{H}}_{1}=$ estimativa do componente de variância devido aos efeitos de dominância dos genes;

$\hat{\mathrm{H}}_{2}=$,estimativa do componente da variância genética do minante corrigido para a distribuição gênica. Indi ca a assimetria dos efeitos positivos e negativos dos genes. Teoricamente $\mathrm{H}_{1}>\mathrm{H}_{2}$ se $\mathrm{H}_{1}=\mathrm{H}_{2}$ há simetria entre os genes de ef eito positivo e aqueles de efeito negativo.

Para os cálculos desses parâmetros são utilizadas tambërn as seguintes variâncias dos residuos obtidos da anālise da variância do carāter:

$$
\begin{aligned}
& \hat{\mathrm{E}}_{\mathrm{O}}=\text { estimativa da variância de ambiente dos pa- } \\
& \hat{\mathrm{E}}_{2}=\text { estimativa da variância de ambiente das pro }
\end{aligned}
$$


Neste estudo, quando as variâncias dos resíduos $E_{\mathrm{O}}, \mathrm{E}_{2}, \mathrm{E}_{\mathrm{O} 2}$ foram homogêneas segundo o teste Bartlett (STEEL \& TORRIE, 1980), para a estimação dos parâmetros D, $\mathrm{F}, \mathrm{H}_{1}$ e $\dot{\mathrm{H}}_{2}$ foram usadas as fórmulas adaptadas do trabalho de SINGH \& SINGH (1984b), nas quais é usado o resíduo geral E $E_{02}$. Desse modo tem-se:

$$
\begin{aligned}
& \hat{D}=V_{p}-E_{O 2} \\
& \hat{F}=4 V_{p}-8 \bar{C}_{i}-\frac{4(n-2) E_{O 2}}{n} \\
& \hat{H}_{1}=4 V_{p}+16 \bar{V}_{i}-16 \bar{C}_{i}-\frac{4(5 n-4) E_{O 2}}{n} \\
& \hat{H}_{2}=16 \bar{V}_{i}-16 V_{i}-\frac{16(n-1) E_{O 2}}{n}
\end{aligned}
$$

Quando os residuos $\dot{\mathrm{E}}_{\mathrm{O}}, \mathrm{E}_{2}$ e $\mathrm{E}_{\mathrm{O} 2}$ foram heterogêneos foram usadas as fórmulas adaptadas de HAYMAN (1958), nas quais são utilizadas as variâncias dos residuos dos parentais $\left(E_{0}\right)$ e das progẽnies $F_{2}\left(E_{2}\right)$, assim tem-se que:

$\hat{D}=V_{p}-E_{o}$

$\hat{F}=4 V_{p}-8 \bar{C}_{i}-\frac{4(n-2) \cdot E_{O}}{n}$

$\hat{\mathrm{H}}_{1}=4 \mathrm{~V}_{\mathrm{p}}+16 \overline{\mathrm{V}}_{i}-16 \overline{\mathrm{C}}_{i}-\frac{4}{\mathrm{n}}\left[\mathrm{n} \mathrm{E}_{\mathrm{O}}+4(\mathrm{n}-1) \mathrm{E}_{2}\right]$

$\hat{\mathrm{H}}_{2}=16 \overline{\mathrm{V}}_{i}-16 \mathrm{~V}_{\bar{i}}-\frac{16\left[(n-1) E_{0}+\left(n^{2}-2 n+2\right) E_{2}\right]}{n^{2}}$ 
O erro padrão de cada componente genético foi estimado calculando-se a variância $\left(S^{2}\right)$ a partir da diferença $c_{i}-v_{i}$ através da seguinte fórmula (HAYMAN, 1954b);

$$
S^{2}=\frac{1}{2}\left[\operatorname{Var}\left(C_{i}-v_{i}\right)\right] ;
$$

em seguida, multiplicando-se essa variância pelo multiplicador específico para cada parâmetro e dimensão do dialejo apresentado por FERREIRA (1985).

A significância dos parâmetros foi testada se gundo SINGH \& CHAUDHARY (1979) através do teste " $t$ " com $n-2$ graus de liberdade. O valor de "t" é estimado dividindossea estimativado parâmetro pelo erro padrão da estimativa do parâmetro, as sim tem-se:

$$
t=\frac{\text { estimativa do parâmetro }}{\text { erro padrão da estimativa do parâmetro }}
$$

Desse modo, para que o parầmetro seja signifi cativio ao nível de probabilidade dé 5\%, para n igual a dez, nove e oito, os valores de "t" calculados devem ser maiores que 2,$31 ; 2,36$ e 2,45 , respectivamente.

A partix dos componentes da variância genética $D, \hat{F}, \ddot{H}_{1}$ e $\mathrm{H}_{2}$ foram estimados os seguintes parâmetros de uma população a ser formada pela recombinação dos dez parentais pesquisados:

a) Grau méaio de dominância (gâa)

$$
\text { gîd }=\left(\hat{\mathrm{H}}_{1} / \hat{\mathrm{D}}\right) \cdot 0,5
$$


gm̂d $=0$, indica ausência de dominância

$0<$ ĝ̀d $<1$, indica dominância parcial

ĝ̀d $=1$, indica dominância completa

gîd > l, indica sobredominância

b) Proporção entre genes dominantes (NND) e re cessivos ( $(\hat{N} R)$ nos parentais:

$$
\frac{\hat{N} D}{\hat{N} R}=\frac{\left(4 D H_{1}\right)^{0,5}+F}{\left(4 D H_{1}\right)^{0,5}-F}
$$

$\hat{\mathrm{N} D} / \hat{\mathrm{N} R} \simeq 1$, indica que os genes dominantes e recessivos estão uniformemente distribuidos nos parentais;

$\hat{N} D / \hat{N} R>1$, indica maior freqüência de genes dominante em relação aos recessivos nos parentais:

$\hat{N} D / \hat{N} R<I$, indica maior freqüência de genes recessivas em relação aos dominantes nos parentais.

c) Produto das freqüências médias dos alelos de efeitos positivos e negativos nos locos onde ocorre dominância:

$$
\mathrm{uV}=\frac{\mathrm{H}_{2}}{4 \mathrm{H}_{1}}
$$


O valor máximo teórico dessa expressão é 0,25. Quando este valor é obtido significa que os alelos com efeitos positivos e os alelos com efeitos negativos estáo distribuidos uniforme mente nos parentais. Valores diferentes de 0,25 indicam distribuição desuniforme dos ale los que contribuem para aumentar e dos que contribuem para diminuir a expressão do carātex.

d) Constância da relação entre efeitos de dominância e efeitos aditivos (MATHER \& JINKS, 1982; TOLEDO \& KIIHI, $1982 \mathrm{~b}$ E SANTOS, 1984).

$$
(u-v) \frac{h}{d}=\frac{(l / 2 F)}{\left[D\left(H_{1}-H_{2}\right)\right]^{0.5}}
$$

Quando essa expressäo tem valor próximo da unidade indica uma constância da razão $h / d$ e corresponde a uma contribuição uniforme de to dos os locos para o gî̀d do carátex. Valor pró ximo de zero indica que os valores de $h e d$ variam independentemente nos diferentes locos. Essa expressão só tem validacke quanão os ge-nes dominantes e recessivos têm freqüências diferentes. 
e) Nūmero de fatores efetivos $(\hat{N})$. Estimado a partir da fórmula apresentada para ageração $F_{1}$ por JINKS (1954) e adaptada para $F_{2}$ por SANTOS (1984):

$$
\hat{N}=\frac{16\left(\mathrm{ML}_{2}-\mathrm{MI}_{0}\right)^{2}}{\mathrm{H}_{2}} ;
$$

o valor de $\hat{\mathrm{N}}$ será subestimado se os efeitos de dominância dos genes não forem iguais em magnitude e direção e a distxibuição dos genes nos parentais for correlacionada. Esse parâmetro não considera os genes sem dominância.

\section{f) Herdabiiidade}

A herdabilidade foi estimada no sentido restrito $\left(h_{r}^{2}\right)$ e no sentido amplo $\left(h_{a}^{2}\right)$ ao nivel de mêđia de repetições. Foram usadas as furmulas apresentadas por MATHER \& JINKS (1982).

$$
h_{r}^{2}=\frac{\frac{1}{2} D+\frac{1}{2} H_{1}-\frac{1}{2} H_{2}-\frac{1}{2} E}{\frac{1}{2} D+\frac{1}{2} H_{1}-\frac{1}{4} H_{2}-\frac{1}{2}+\frac{E_{02}}{b}}
$$




$$
h_{a}^{2}=\frac{\frac{1}{2} D+\frac{1}{2} H_{1}-\frac{1}{4} H_{2}-\frac{1}{2} F}{\frac{1}{2} D+\frac{1}{2} H_{1}-\frac{1}{4} H_{2}-\frac{1}{2} F+\frac{E_{02}}{b}}
$$

onde:

$$
\mathrm{b}=\text { nümero de blocos ou repetições }
$$

Com base na expressão mëdia coo carâter

e na soma da covariância mais variância $\left(C_{i}+V_{i}\right)$ foi estima do o limite de seleção segundo CHAUDHARY \& SINGH (1979).

Quando o coeficiente de determinação $\left(R^{2}\right)$ da regressão de $\overline{\mathrm{Y}}_{i}$ sobre $\mathrm{C}_{i}+\mathrm{v}_{i}$ é próximo da uniàảe é possivel estimar os limites de seleção máximo é mínimo de un caráter. Ou seja, é possivvel estimar os valores dos caracte-res para linhagens completamente dominantes e completamente recessivas.

Os valores das variâncias e covariâncias correspondentes ao genōtipo completamente dominante são respectivamente $V D$ e $C D$ e dos genötipos completamente recessivos são VR e CR. Tendo-se que:

$$
\begin{aligned}
& \mathrm{VD}=\mathrm{v}_{\mathrm{p}} \cdot \mathrm{x}_{1}^{2} \\
& \mathrm{CD}=\mathrm{v}_{\mathrm{p}} \cdot \mathrm{x}_{1} \\
& \mathrm{VR}=\mathrm{v}_{\mathrm{p}} \cdot \mathrm{x}^{2} \\
& \mathrm{CR}=\mathrm{V}_{\mathrm{p}} \cdot \mathrm{x}_{2}
\end{aligned}
$$


onde: $\mathrm{x}_{1}$ e $\mathrm{x}_{2}$ são as raízes da equação:

$$
v_{p} \cdot x^{2}-v_{p} \cdot x+\left(\bar{c}_{i}-\bar{v}_{i}\right)=0
$$

E importante ressaltar que admitindo-se que a frequência de um alelo A (dominante) è u e a do alelo recessivo a é $\mathbf{v}, \mathbf{u}+\mathbf{v}=\mathbf{l}$. Desse modo, quando alguma raiz da equação $\left(x_{1}\right.$ ou $\left.x_{2}\right)$ è maior que a unidade, despreza-se a parte inteira. Assim, os valores dos genótipos completamente domi nante (YD) e completamente recessivo (YR) são os seguintes:

$$
\begin{aligned}
& \mathrm{YD}=\overline{\mathrm{Y}}_{i}+\mathrm{b}\left[(\mathrm{CD}+\mathrm{VD})-\left(\overline{\mathrm{C}}_{i}+\overline{\mathrm{V}}_{i}\right)\right] \\
& \left.\mathrm{YR}=\mathrm{Y}_{i}+\mathrm{b}\left[(\mathrm{CR}+\mathrm{VR})-\mathrm{C}_{i}+\mathrm{V}_{i}\right)\right]
\end{aligned}
$$

onde:

$$
b=\frac{\operatorname{Cov}\left(Y_{i}, z_{i}\right)}{\operatorname{Var} z_{i}} ;
$$

sendo:

$$
\mathrm{z}_{i}=\mathrm{C}_{i}+\mathrm{v}_{i}
$$

Essa metodologia de anälise para $F_{2}$ a exemplo da metodologia para Fi (HAYMAN, 1954b) só pode ser usada quando os dados atendem às restrições do modelo genētico. Des se modo, para testar se as restrições estão sendo atendidas foi feita uma análise da homogeneidade das diferenças $c_{i}-v_{i}$ 
para todos os caracteres. As variâncias $\left(V_{i}\right)$ e as covariâncias $\left(C_{i}\right)$ foram calculadas para cada uma das progênies do i-ési mo parental em cada uma das repetições, em seguida obteve-se a diferença $C_{i}-V_{i}$ e procedeu-se $\vec{a}$ anälise em blocos casualizados dessas diferenças. Quando o teste "F" foi não significa tivo a hipótese de romogeneidade foi aceita. Alēm desse tes te fez-se tambēm o teste de significância do coeficiente de regressão $\mathbf{b}$, da regressão de $\mathbf{C}_{\mathbf{i}}$ sobre $\mathrm{V}_{\mathbf{i}}$, em relação a zero e a unidade pelo teste " $t$ ". Neste teste quando b não difere significativamente da unidade não hã razão para se rejeitar o modelo aditivo-dominante. Desse modo, só se procedeu à análise genētica quando houve homogeneidade das diferenças $c_{i}-V_{i}$ e quando b não diferiu significativamente da unidąe.

Para os caracteres em que o teste "F" foi signi ficativo, indicando heterogeneidade das diferenças $C_{i}-V_{i}$ e/ ou o coeficiente de regressão b diferiu a unidade fềz-se as análises das subtabelas dialēlicas com $(n-1) \times(n-1)$ e em alguns casos $(n-2) \times(n-2)$ (HAYMAN, 1954b). As anālises genēticas só foram realizadas quando as restrições da metodologia foram razoavelmente atendidas.

\subsubsection{Anālise de GRTFFING (1956b)}

Nessa anáıise foram usados dez parentais, os quais foram deliberadamente escolhidos, e suas 45 progênies $\mathrm{F}_{2}[\mathrm{n}(\mathrm{n}-1) / 2]$, não tendo sido incluidos os cruzamentos recíprocos. 
Com base no procedimento de escolha dos parentais e no material disponível para estudo foi utilizado para a análise o método 2 e o modelo misto $B$, apresentados por GRIFFING (1956b). Nesse modelo os efeitos de tratamentos são fixos e os de bloco e erro experimental são aleatórios. Os efeitos de tratamento sendo fixos implicam que as inferências feitas são válidas somente para o material experimental usado. Neste caso, segundo GRIFFING (1956b)os objetivos básicos do estudo são: a) comparação da capacidade de combinação dos parentais quando eles próprios são usados como testa dores; e b) identificação das melhores combinações híbridas.

Para a anālise da capacidade de combinação foi utilizado 0 mesmo modelo da análise de variância, desta feita fazendo-se o desdobramento dos efeitos de tratamento em capacidade geral de combinação (CGC) e capacidade específica de combinação (CEC). Desse modo, tem-se a seguiñ te equação:

$$
x_{i j k}=u+g_{i}+g_{j}+s_{i j}+\frac{1}{b} \sum_{k-1}^{b} e_{i j k}
$$

onde:

$$
\begin{aligned}
u= & \text { média geral do dialelo } \\
g_{i}= & \text { efeito da CGC do parental de ordem } i \\
g_{j}= & \text { efeito da CGC do parental da ordem } j \\
s_{i j}= & \text { efeito da CEC para o cruzamento entre os paren- } \\
& \text { tais de ordem } i \text { e de ordem } j . \text { Para o caso dos }
\end{aligned}
$$




$$
\begin{aligned}
& \text { parentais } s_{i j}=s_{i j}=s_{j j} \\
i, j & =1,2,3, \ldots \ldots \ldots, n \\
k & =1,2,3, \ldots \ldots \ldots, b
\end{aligned}
$$

Para que esse modelo seja válido são impostas as seguintes restrições:

$$
\begin{aligned}
& e_{i j k} \text { - deve ter distribuição normal e ser independen- } \\
& \sum_{i=1}^{n} g_{i(j)}=0, \\
& \sum_{j} s_{i j}+s_{i i}=0, \text { para cada } i \\
& \text { O esquema de análise da variância para CGC e }
\end{aligned}
$$
CEC é apresentado na Tabela 5.

Os efeitos da média, CGC e CEC forain estimados através das seguintes fórmulas, respectivamente;

$$
\hat{\mathrm{u}}=\frac{2}{n(n+1)} Y \ldots ;
$$




$$
\begin{aligned}
\hat{g} & =\frac{1}{n+2}\left(Y_{i}+Y_{i j}-\frac{2}{n} Y_{. .}\right) ; \\
\hat{s}_{i j} & =Y_{i j}-\frac{1}{n+2}\left(Y_{i .}+Y_{i i}+Y_{. j}+Y_{j j}\right)+\frac{2}{(n+1)(n+2)} Y_{\ldots i}
\end{aligned}
$$

As variâncias do efeito da média e dos efeitos e das diferenças entre os efeitos da CGC e da CEC foram estimados pelas seguintes fórmujas:

$\operatorname{Var}(\hat{\mathrm{u}})=\frac{2}{\mathrm{n}(\mathrm{n}+1)} \hat{\sigma}^{2}$;

$\operatorname{var}\left(\hat{g}_{i}\right)=\frac{n-1}{n(n+2)} \hat{\sigma}^{2} ;$

$\hat{\operatorname{Var}}\left(\hat{\mathrm{s}}_{\mathrm{ii}}\right)=\frac{\mathrm{n}(\mathrm{n}-1)}{(\mathrm{n}+1)(\mathrm{n}+2)} \hat{\sigma}^{2}$;

$\hat{\operatorname{Var}}\left(\hat{s}_{i j}\right)=-\frac{n^{2}+n+2}{(n+1)(n+2)} \hat{\sigma}^{2}$, para $i \neq j$

$\hat{\operatorname{Var}}\left(\hat{g}_{i}-\hat{g}_{j}\right)=\frac{2}{n+2} \hat{o}^{2}, \operatorname{para} i \neq j$

$\hat{\operatorname{Var}}\left(\hat{s}_{i j}-\hat{s}_{i j}\right)=\frac{2(n-2)}{n+2} \hat{\sigma}^{2}$, para $i \neq j$

$\hat{\operatorname{Var}}\left(\hat{s}_{i j}-\hat{s}_{i j 1}\right)=\frac{2(n+1)}{n+2} \quad \hat{\sigma}^{2}$, para $i \neq j$ e $j \neq j^{\prime}$ 


$$
\hat{\operatorname{Var}}\left(\hat{s}_{i j}-s_{i^{\prime} j^{\prime}}\right)=\frac{2 n}{n+2} \hat{\sigma}^{2}, \begin{gathered}
\text { para } i \neq j, i^{\prime}, j^{\prime}, \quad j \neq i^{\prime}, j^{\prime} e \\
i^{\prime} \neq j^{\prime}
\end{gathered}
$$

Alēm dessas variâncias para a média de qualquer parental ou progênie $\mathrm{F}_{2}$ tem-se que:

$$
\operatorname{var}\left(x_{i j}\right)=\hat{\sigma}^{2}=Q_{M}^{M} e^{\prime i}
$$

e que a variância da diferença entre duas médias quaisquer é:

$$
\hat{\operatorname{Var}}\left(\overline{\mathrm{x}}_{i j}-\overline{\mathrm{x}}_{i \cdot j !}\right)=2 \hat{\sigma}^{2}
$$

E importante salientar que em $\mathrm{F}_{2}$ a contribuição dos efeitos de dominância para a média e para a variân cia ficam.respectivamente reduzidas à metade e a um quarto em relação à geração $\mathrm{F}_{1}$. Isso porque, em média 50\% do $10 c 0$ s que estavam em heterozigose en $F_{1}$ tornam-se homozigöticos em $\mathrm{F}_{2}$. Desse modo, O $\mathrm{CEC}$ em $\mathrm{F}_{2}$ não é estimada em toda sua plenitude, uma vez que depende principalmente dos exeitos de dominância. Por outro lado, a CGC que depende principalmente de efeitos aditivos é melhor estimada. MATHER \& JINKS (1982) relataram que a perda de informação sobre a contribuição da dominância pode ser compensada pelo uso de progênies $\mathrm{F}_{2}$ maiores. Esse é um aspecto importante para soja e outras plantas autögamas onde a obtenção de grancies quantidades de sementes $F_{1}$ é relativamente diffícil e onde 0 interesse maior é sobre a CGC. 


\subsection{HeTEROSE E HETEROBELTIOSE}

A heterose e a heterobeltiose correspondem respectivamente, a avaliação da geração hỉbrida em relação à média dos parentais e à média do parental superior. Como nes te estudo a geração hỉbrida foi a $\mathrm{F}_{2}$, para que os resultados fossem expressos ao nivel de $\mathrm{F}_{1}$ os mesmos foram multiplica dos por dois.

As estimativas foram obtidas através das seguintes fórmulas, expressando-se os resultados em porcenta gem:

$$
\begin{aligned}
\text { Heterose }(\mathrm{H} t) & =\frac{2\left(\overline{\mathrm{F}}_{2}-\overline{\mathrm{MP}}\right)}{\overline{\mathrm{MP}}} \cdot 100 ; \\
\text { Heterobeltiose }(\mathrm{Hb}) & =\frac{2\left(\overline{\mathrm{F}}_{2}-\overline{\mathrm{PS}}\right)}{\overline{\mathrm{P} S}} \cdot 100 ;
\end{aligned}
$$

onde:

$$
\begin{aligned}
& \overline{\mathrm{F}}_{2}=\text { inèdia da progênje } \mathrm{F}_{2} \cdot \\
& \overline{\mathrm{MP}}=\frac{\overline{\mathrm{P}}_{i}+\overline{\mathrm{P}}_{j}}{2}, \text { média dos parentais da progênie } F_{2}(i j) ;
\end{aligned}
$$$$
\overline{\mathrm{PS}}=\text { média do respectivo parental superior. }
$$

A significância da heterose e da heterobeltio se foi testada através do teste " $t$ " ao nível de probabilidade de $5 \%$ 


\subsection{Cruzamentos em cadeia}

Os cruzamentos em cadeia constituem um tipo de esquema no qual cada parental è cruzado com dois outros parentais, sendo usado uma vez como parental feminino e outra como parental masculino. Esse è um aspecto importante porque tanto em termos de material genêtico nuclear como citoplasmātico os parentais estarão igualmente representados. Entretanto, alguns materiais não funcionam bem como parental feminino, sendo dificil obter sementes com citoplasma desses materiais.

Esquematicamente os cruzamentos em cadeia seriam da seguinte forma (a seta indica a direção do pólen):

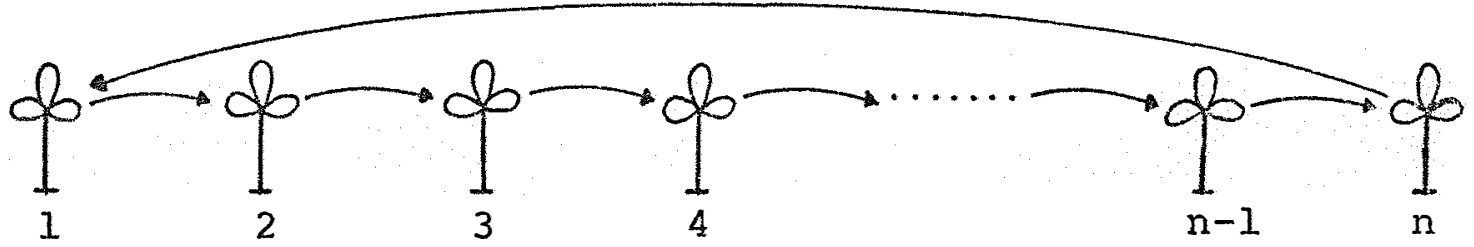

Em essência esse è um dialelo parcial em sua forma mais simples, na qual somente uma amostra dos cruzamen tos possiveis para cada parental é avaliada. Como o número total de cruzamentos em um dialelo é igual a ns/2, onde s è - número de cruzamentos de cada parental, para $s=20$ núme ro total de cruzamentos para o esquema em cadeia é igual 
a n. Esse nūmero de cruzamentos ébem menor que o necessário em um dialelo completo, onde $s=n-1$. Neste estudo que envolve dez parentais, para o dialelo completo foram necessá rios 45 cruzamentos $(n(n-1) / 2)$, enquanto que para os cruzamentos em cadeia foram necessários somente dez, ou seja, n cruzamentos (Tabela 6).

SINGH \& SCHAUDHARY (1979) iapresentaram um mode10 de análise para dialelos parciais que pode ser aplicado a esse esquema de cruzamento. Ressaltam porém, que quando s è menor que $\mathrm{n} / 2$ os resultados perdem em precisão. MIRANDA FILHO (1982), apresentou . uma metodologia para o estudo dos componentes de variância genética em progênies de cruzamentos em cadeia.

Por raciocínio indutivo obteve-se que para n parentais ( $n>2$ ) o número de diferentes cadeias (NC) que po. dem ser obtidas é igual ao arranjo de n, n a n, dividido por $2 n$, ou seja, $N C=A n, n / 2 n=n ! /[(n-n) ! 2 n]$. Tomando como exemplos $n=3$ e $n=4$ tem-se que:

para $n=3$, parentais 1,2 e 3, NC $=\frac{3 !}{(3-3) ! 2 \times 3}=1$, a ünica cadeia possivel seria:

$1 \times 2 \times 3 \times 1$;

para $n=4$, parentais $1,2,3$ e $4, N C=\frac{4 !}{(4-4) ! 2 \times 4}=3$, as três cadeias possiveis seriam:
a) $1 \times 2 \times 3 \times 4 \times 1$;
b) $1 \times 3 \times 4 \times 2 \times 1$
c) $1 \times 4 \times 2 \times 3 \times 1$ 
A princípio, quanto ao número de cruzamentos exigidos para a obtenção das progênies híbridas, os cruzamentos em cadeia mostram-se mais eficientes que o dialelo completo.

Neste estudo foram feitas comparações entre os dois esquemas de cruzamento quanto à média, variância fenotípica e variabilidade genética, esta avaliada através do coeficiente de variação genética. JoHNSON et alii (1955a) re lataram que este coeficiente é de considerável importância na comparação de variabilidade genética em populações heterogêneas.

Os parâmetros mencionados para cada esquema de cruzamento foram estimados do seguinte modo:

$$
\text { Média }(\bar{x})=\frac{1}{n} \sum_{i=1}^{n} x_{i}
$$

onde:

$$
\begin{gathered}
\dot{\mathrm{x}}_{\mathrm{i}}=\text { nümero total de plantas avaliadas do carāter na i-ésima planta } \\
\mathrm{V}_{\mathrm{F}}=\text { variância fenotípica } \\
\mathrm{V}_{\mathrm{F}}=\frac{1}{\mathrm{n}-1} \cdot\left[\Sigma \mathrm{x}_{i}^{2}-\frac{\left(\Sigma \mathrm{x}_{i}\right)^{2}}{\mathrm{n}}\right]
\end{gathered}
$$




$$
\begin{aligned}
\mathrm{V}_{\mathrm{E}}= & \text { variância de ambiente (média das variâncias dos } \mathrm{n} \\
& \text { parentais) }
\end{aligned}
$$

$$
v_{E}=\frac{1}{n}\left[\begin{array}{ll}
n & \\
i=1 & V_{E P}
\end{array}\right]
$$

onde:

$$
\begin{aligned}
\mathrm{V}_{\mathrm{EP}_{i}=} & \text { variância estimada para o i-ésimo parental, como } \\
& \text { todos parentais são considerados homozigóticos, } \\
& \text { essa variância expressa uma estimatịva da variân } \\
& \text { cia de ambiente. }
\end{aligned}
$$

Coeficiente de variação genética (CVG):

$$
C V G=\frac{\sqrt{V_{G}}}{\bar{x}} \cdot 100
$$

onde:

$$
\mathrm{V}_{\mathrm{G}}=\mathrm{V}_{\mathrm{F}}-\mathrm{V}_{\mathrm{E}}
$$

Como o número de cadeias que pode ser obtido a partir dedez parentais è muito elevado, foram tomadas cinco cadeias ao acaso. O estudo foi realizado somente com o caráter produtividade de planta individual.

A. população de plantas de cada cruzamento foi formada a partir das plantas individuais avaliadas em cada repetição. Em cada esquema de cruzamento a população de plantas foi composta pelas plantas dos cruzamentos que compu 
69.

nham o respectivo esquema. Assim, no esquema dialélico to dos os cruzamentos foram incluídos. Já nos cruzamentos em cadeia somente foram incluídos aqueles que faziam parte da cadeia. 
70.

\section{RESULTADOS E DISCUSSÃO}

As anālises de variância para os caracteres foram realizadas inicialmente em látice: Entretanto, com exceção dos caracteres APF e APM, a eficiência do látice en relação a blocos casualizados e também o coeficente de variação (LV\%) para a maioria dos carac teres, foram relativamente baixos (Tabela 7). Desse modo, as análises foram refeitas em blocos casualizados, reunindo somente os tratamentos referentes aos dez parentais e às 45 progênies $\mathrm{F}_{2}$.

\subsection{ANALISE DE VARIÂNCIA}

Os resultados das análises de variância em blocos casualizados para os caracteres número de dias para o florescimențo (NDF), número de internódios no florescimento (NIF) e altura da planta no florescimento (APF) são apresentados na Tabela 8; número de dias para a maturação (NDM), nú mero de internódios na maturação (NIM) e altura da planta na maturação (APM), na Tabela 9; acamamento (AC) e valor agronômico (VA), na Tabela 10; e produtividadede planta individual (PPI) e produtividade da parcela (PP), na Tabela 1l. Nessas tabelas, para todos cs caracteres são apresentados tambēm 
- coeficiente de variação e o valor do Qui-quadrado $\left(x^{2}\right)$ para a hcmogeneidade dos resíduos.

A precisão das análises avaliadas através dos coeficientes de variação apresentou níveis bastante satisfatôrios. Os coeficientes de variação pouco diferiram daqueles obtidos na análise em látice. Para seis caracteres foram inferiores a 10\%, para outros três foram inferiores a $20 \%$ e apenas para o caráter PPI ficou em torno de $20 \%$.

O teste de homogeneidade das variâncias dos resíduos (STEEL \& TORRIE, 1980) foi significativo para os caracteres NDM, APM (Tabela 9), Ac e VA (Tabela 10). Desse mo do, para testar a significância das fontes de variação para os caracteres que apresentaram residuos homogêneos, o teste "F" foi feito com o resíduo geral, ou seja, não desdobrado e para os caracteres que apresentaram resíduos heterogèneos o teste "F" foi realizado com o resíduo específico, ou seja, pela interação da respectiva fonte de variação com blocos.

Para os caracteres NDF, APF (Tabela 8), NIM (Tabela 9) e PPI (Tabela 11), são apresentados duas análises de variância. A primeira análise envolveu o dialelo $10 \times 10$; a segunda anälise foi obtida após exlcusão de um ou dois parentais. A realização dessa segunda análise foi necessária devido ao fato de que para esses caracteres as análises do dialelo 10 x 10 não atendeu às restrições da metodologia de HAYMAN (1958). Desse modo, foram realizadas novas análises 
com dialelos $(n-1) \times(n-1)$ ou $(n-2) \times(n-2)$, conforme recomendadação de HAYMAN (1954b) para os casos onde há falha de alguma ou algumas das hipóteses do modelo. A segunda análise apresentada corresponde, dentre as diversas tentativas realizadas com a exclusão de diferentes parentais, aquela que melhor atendeu às restrições impostas para a análise dialélí ca de HAYMAN (1958).

Com exceção da produtividade medida a partir de todas as plantas da parcela (PP), os demais caracteres fo ram analisados a partir da média das observações de plantas individuais amostradas na parcela. As Tabelas 8 a 11 mostram que para todos os caracteres os grupos (parentais mais progênies $\mathrm{F}_{2}$ ) apresentaram diferenças significativas ao nível de probabilidade de 5\%. Mostram tambëm através do desdo bramento da soma de quadrados de grupos e de residuo, que tanto parentais como progênies $F_{2}$ diferiran entre si ao nível de probabilidade de 1\%. A comparação dos parentais com as gerações $F_{2}$ foi feita atravēs da fonte de variação parentais versus $F_{2}$ ( $P$ vs. $F_{2}$ ), a qual geralmente foi não significativa, com exceção dos caracteres NDF e Ac; nestes caracteres houve $\because$ diferenças significativas pelo teste "F" (5\%).

A significância ao nível de $1 \%$ para os quadra dos médios dos parentais e das progênies $F_{2}$ mostra que há uma grande variabilidade nesse conjunto de parentais e evidencia a possibilidade de formação de uma população de base genética bastante ampla a partir desse material. 


\subsection{Comportamento dos parentais, progênies $F_{2} E$ AVALIACÃO DA HETEROSE E HETEROBELTIOSE}

\subsubsection{Caracteres relacionados ao florescimento}

A média e a variância dos parentais e progênies $\mathrm{F}_{2}$ e as porcentagens de heterose e heterobeltiose para os caracteres NDF, NIF e APF e respectivos desvios mínimos significativos (DMS) ao nível de 5\% pelo teste "F" para comparações entre parentais e entre progênies $F_{2}$, são apresentados na Tabela 12 .

Apesar de se tratar de um grupo de cultivares precoces, houve diferença significativa (5\%) para NDF. O pa rental FT 81-1835 foi o mais precoce apresentando uma média de 42 dias, entretanto não diferiu significativamente dos pa rentais IAC-Foscarin-31, Dëcada e Forrest. Os parentais SOC 81-79, Hale 32l, Paraná, Primavera e Coker 136 formaram um grupo intermediário e o parental palmetto foi o mais tardio, diferindo significativamente de todos os outros e apresentan do uma média de cerca de 56 dias para o iníciodoflorescimen to. Os parentais SOC 81-79, IAC-Foscarin-31, Palmetto e Forrest apresentaram variâncias relativamente altas para esse caracter sendo, inclusive, superiores às variências. estimadas envários cruzamentos. Isso leva à suposição de que esses parentais poderão não estar totalmente em homozigose pa ra $\circ \mathrm{NDF}$. 
Nas progênies $F_{2}$, $O$ NDF variou de 43 no cruzamento IAC-Foscarin-3l x Forrest a 51 no cruzamento Paraná $x$ Palmetto. Portanto, esses valores colocaram-se entre os valores extremos observados nos parentais. Os cinco cruzamentos mais precoces foram IAC-Foscarn-31 x Forrest (42,5 dias), Década x FT 81-1835 (43,1 dias), Década x Forrest (43,4 dias), IAC-Foscarin-31 x Década $(43,5$ dias) e IAC-Foscarin-3I x FT 81-1835 (43,6 dias). Esses cruzamentos apresentaram respectivamente as variâncias de 6,$24 ; 5,54 ; 7,66 ; 3,50$ e 10,61 (dias) ${ }^{2}$. Constata-se que apenas quatro parentais são envol vidos nesses cruzamentos e nos onze cruzamentos que seguem a esses em precocidade pelo menos um desses parentais está envolvido. Desse modo, pode-se concluir que esses parentais possuem um grande potencial para precocidade.

A heterose foi predominantemente negativa; dos 45 cruzamentos, 32 apresentaram heterose negativa, das quais apenas sete foram significativas. Os valores mais expressivos foram obtidos nos cruzamentos Coker 136 x Palmetto $(-10,75 * *)$, Primavera $x$ Palmetto $(-11,97 * *)$ e Hale $321 \times$ Pal metto $(-12,26 * *)$. Entre as estimativas positivas apenas duas foram significativas, nos cruzamentos 'Primavera $x$ Forrest $\left(8,75^{* *}\right)$ e Forrest $\mathrm{x}$ FT $81-1835(13,14 * *)$. Esses resultados mostram que houve uma tendência de dominância do florescimento precoce.

A heterobeltiose foi calculada com relação ao parental mais precoce e com relação ao parental mais tardio. 
Os resultados obtidos em relação ao parental mais precoce mos tramque na maioria dos cruzamentos a progênie $F_{2}$ foi mais tardia que o parental mais precoce e em 17 cruzamentos diferiram significativamente desse parental. Em alguns poucos casos, essa heterobeltiose foi negativa, mas de pequena magnitude (não chegando a ser significativa). As estimativas de heterobeltiose em relação ao parental mais tardio, com exceção dos cruzamentos Coker 136 x Primavera e Forrest x FT 811835, nos quais tiveram respectivamente os valores de 0,40 e 8,63\%, foram negativas, sendo signifivativas em 25 cruzamentos. Esses resultados mostram que houve uma tendência das progênies $\mathrm{F}_{2}$ terem tempo para florescimento intermediário em relação aos respectivos parentais. Pelas estimativas da mẹ dia. e da variância do NDF como no cruzamento IAC-Foscarin -$31 \times$ FT 81-1835, respectivamente 43,6 dias e 10,61 (dias) ${ }^{2}$, evidencia-se a possibilidade de serem obtidos materiais mais precoces que os presentes neste grupo de parentais.

Em uma série de cruzamentos VEATCH (1930) obteve uma freqüência maior de cruzamentos apresentando hetero se e heterobeltiose positivas, ou seja, as progênies foram mais tardias que os parentais, portanto um resultado diferen te do observado neste trabalho. Outros autores, entretanto, como CAMPOS (1979) e KAW \& MENON (1979) obtiveram heterose e heterobeltiose predominantemente negativas. CHAUDHARY \& SINGH (1974) em 17 cruzamentos obtiveram heterobeltiose nega tiva em todos, sendo 15 significativas. E importante salien 
tar que nesses estudos a heterobeltiose foi estimada somente em relação ao parental mais tardio. Portanto, os resultados obtidos, estão de acordo com os demais autores e confirmam a dominância do florescimento precoce; só houve exceção à esta tendència no trabalho de VEATCH (1930).

O NIF variou de 7,1 no parental FT 81-1835 a 11,2 em Palmetto, o qual diferiu significativamente de todos os outros parentais. As variâncias dos parentais foram rela tivamente uniformes, sugerindo que os mesmos têm um razoável nível de homozigose para esse carāter. Nas progênies $\mathrm{F}_{2} \mathrm{O}$ NIF variou de 7,1 no cruzamento IAC-Foscarin-31 x SOC $81-79$ a 10,0 no cruzamento Paraná x Palmetto. Entre os cruzamentos que apresentaram maiores valores para NIF, seguiram-se Coker 136 x Palmetto, Década x Palmetto, Primaverax Palmetto, SOC 81-79 x Palmetto e Forrest $\mathrm{x}$ Palmetto, respectivamente com 9,$9 ; 9,8 ; 9,6 ; 9,4$ e 9,3 internōdios no florescimento. Esses dados mostram que o parental palmetto tem uma forte ca pacidade para elevar o NIF. As variäncias expressas em $\sqrt{x+I}$, foram relativamente uniformes, variando de 0,0235 no cruzamento Paraná x Coker 136 a 0,0903 no cruzamento IAC- Foscarin-31 x Forrest. Essa pouca variação reflete a pequena divergência entre os parentais para esse carāter. Apesar disso, há possibilidade de se aumentar o NIF através da seleção.

A heterose para NIF foj positiva para a maio- 
ria dos cruzamentos e variou de $-15,1$ no cruzamento IAC-Foscarin-31 x SOC 81-79 a 27,8\%** no cruzamento Primavera x FT 81-1835. Entretanto, alēn deste cruzamento apenas coker 136 x Hale 321, Primavera x Década e Primavera x Forrest apresen taram valores significativos, respectivamente $18,1 * *, 21,3 * *$ e 12,2\%*. Apenas o cruzamento Hale 321 x Palmetto apresentou heterose negativa significativa $(-14,6 \% *)$. Esses resultados sugerem uma tendência das progênies $F_{2}$ apresentarem NIF em torno da mëdia dos parentais, tendendo a uma leve superioridade.

A heterobeltiose variou de $-43,7 \% * *$ no cruzamento Hale $\mathrm{x}$ Palmetto a $7,7 \%$ a presentado pelos cruzamentos IAC-Foscarin-31 x Forrest e Forrest x FT 81-1835. Na hetero beltiose, a predominância foi de valores negativos, os quais foram significativos em 13 cruzamentos. Isso indica que as progênies $\mathrm{F}_{2}$ situaram-se entre a média dos parentais e o res pectivo parental superior, evidenciando a ocorrência de dominância parcial no sentido do maior NIF.

Para o nūmero de nôs, que se mostra como uma outra medida do mesmo caräter, VEATCH (1930), CAMPOS (1979)e KAW \& MENON (1979) obtiveram resultados semelhantes aos obti dos neste estudo para heterose e heterobeltiose. CHAUDHARY \& SINGH (1974) entretanto, mesmo obtendo um maior nümerc de cruzamentos com heterose negativa obteve valores significati vos somente para heterobeltioses positivas. Isso ocorreu po rém apenas em dois cruzamentos, os quais tinham o cultivar 
clark 63 como parental comum, podendo ser interpretado como uma característica desse parental, uma vez que foi constatada heterobeltiose positiva em todos os cruzamentos em que ele participou.

A APF, nos parentais apresentou uma média de $43,2 \mathrm{~cm}$ e variou de $31,4 \mathrm{~cm}$ no parental Forrest a $62,8 \mathrm{~cm}$ em Palmetto. Os parentais IAC-Foscarin-3l e Palmetto a presenta ram as maiores variâncias, respectivamente 56,0 e 43,1. Inclusive, essas variâncias foram superiores às variâncias de alguns cruzamentos. Entre as progênies $\mathrm{F}_{2}$ a mëdia foi de $44,2 \mathrm{~cm}$ e teve uma variação de $33,0 \mathrm{~cm}$ no cruzamento IAC-Fọ carin-31 x Forrest a $56,2 \mathrm{~cm}$ no cruzamento Paraná x Palmetto. vários cruzamentos apresentâram variâncias relativamente altas as quais refletem a ampla variabilidade que há para APE.

A heterose para APF foi predominantemente positiva, mas foi significativa em apenas quatro cruzamentos: Paranâ x Forrest $(27,2 \% *)$, Coker 136 x Forrest $(24,0 \% *)$, Década $x$ Soc $81-79(32,7 \% *)$ e Forrest $x$ hale $321(20,7 \% * *)$. ES ses resultados sugerem que as progènies $F_{2}$ tenderam a apresentar APF, semelhante à média dos parentais, com uma leve tendência para maior altura.

Para hetercbeltiose, entretanto, a maioria dos cruzamentos apresentou valores negativos; em 13 dos 45 cruza mentos os valores da heterobeltiose foram significativos. Os valores mais expressivos foram observados nos cruzamentos 
IAC-Foscarin-3l x Palmetto e Década x Palmetto, ambos com o valor de $-51,0 \% * *$, FT $81-1835 \times$ Palmetto $(-49,7 \% * *), \quad$ SOC 81-79 x Paimetto $(-44,3 \% * *)$ e Hale 321 x Palmetto $(-39,2 \% * *)$. o parental palmetto está incluído en todos esses cruzamentos, de modo que esses valores negativos da heterobeltiose podem ser atribuídos a el evada altura desse parental $(62,8 \mathrm{~cm})$, a qual diferiu significativamente de todos os outros parentais.

As estimativas da heterose.e heterobeltiose sugerem, portanto, que as progênies tendem a se colocar entre a média dos parentais e o parental superior. Evidencian do a ocorrência de dominância parcial para maior altura no florescimento. KAW \& MENON (1979) obtiveram na média ae 45 cruzamentos, valores negativos para heterose e heterobeltiose, respectivamente $-6,3$ e $-24,3 \%$. Esses dados sugerem que as plantas mais baixas têm os alelos dominantes. Em termos de heterose, portanto, não estão de acordo com os obtidos neste estudo. Entre outros fatores, essa diferença pode ser decorrente das diferenças entre os materiais genéticos e con dições de ambiente em que os estudos foram realizados.

4.2.2. Caracteres relacionados à maturidade

Na Tabela 13 são representadós os dados relativos ao NDM, NIM e APM.

Embora o teste "F" tenha sido significativo, não foi constatada aiferença entre os parentais para NDM. A 
média foi de $123,8+7,03$ dias, com os parentais Haile 321, FT 81-1835 e Década atingindo a maturidade com menos de 120 dias; Primavera, coker 136, Forrest e Paraná com menos de 130 dias; SoC 81-79, Palmetto e IAC-Foscarin-31, entre 130 e 135 dias. Embora não sendo estatisticamente diferentes, a diferença entre o parental mais precoce Hale 321 (113,3 dias) e o mais tardio IAC-Foscarin-31 (133,9 dias) foi em torno de 20 dias, a qual è uma diferença considerável em termos prāticos.

Já entre as progênies $\mathrm{F}_{2}$ houve diferenças sig nificativas ao nível de probabilidade de 1\%, em NDM. A média foi de $120,6 \pm 4,6$ dias, sendo o cruzamento mais precoce FT 81-1835 x Hale 321 (113,1 dias) e o mais tardio IAC-Fosca rin-31 x soc 81-79 (133,1 dias). E importante observar que essa é praticamente a mesma variação apresentada pelos paren tais e que esses dois cruzamentos envolvem respectivamente os parentais mais precoces (Hale 32l) e mais tardio (IAC-Fos carin-31), em termos de maturịdade. As variâncias dentro de progênies $\mathrm{F}_{2}$ foram relativamente altas, com valores observados variando de 2,3 (Paraná $x$ Hale 321) a 52,0 dias ${ }^{2}$ (FT 811835 x SOC 81-79); para o conjunto das 45 progênies $F_{2}$, a va riância média correspondeu a $18,3 \pm 10,9$ dias $^{2}$. Estes valores de variância indicaram a existência de boas perspectivas de seleção de materiais que alcancem a maturidade mais pre-cocemente que os parentais.

A heterose do NDM, foi negativa na maioria dos cruzamentos, foi significativa em apenas 11 deles. 
E importante salientar que o cultivar Paraná participou de nove desses 11 cruzamentos, o que revela o potencial desse cultivar para aumentar a precocidade para a maturidade. A média da heterose foi de $-5,1 \pm 5,7 \%$, indicando que as progênies $F_{2}$ situaram-se em torno da média dos parentais com uma tendência de dominância parcial para maturidäde precoce.

A heterobeltiose foi estimada em relação ao parental de maturidade mais precoce e também em relação ao de maturidade mais tardia. A média de heterobeltiose com relação ao parental mais precoce foi de 1,8 $\pm 7,1 \%$. Poucos cruza mentos apresentaram progênies $F_{2}$ mais precoces que o parental mais precoce, entre estes destacam-se os que envolveram o cultivar Paraná, nos quais todas as progênies apresentaram heterobeltiose negativa. Destas, três foram significativas, nos cruzamentos Paraná x IAC-Foscarin-3l, Paraná x SOC 81-79 e Paraná x Palmetto, respectivamente $-15,9 * ;-11,0 *$ e $-15,7 \%$. As estimativas da heterobeltiose em relação ao parental mais tardio foram predominantemente negativas e em sua maioria significativas. A média foi de $-11,2 \pm 7,2$ e variaram de 2,1 a $-24,5 \% * *$. Estes dados mostram que de um modo geral, as progênies $\mathrm{F}_{2}$ foram mais precoces que os respectivos parentais mais tardios.

Esses resultados estão de acordo com os obtidos por PASCHAL II \& WILCOX (1975) que relataramque as progênies tenderam a ser intermediárias entre os parentais; tambēm são concordantes com CAMPOS (1979) e KAW \& MENON 
que obtiveram médias negativas tanto para a heterose como pa ra a heterobeltiose (neste caso em relação ao parental mais tardio). WEBER et alii (1979), entretanto, em um estudo que foi realizado em quatro anos, obtiveram heterose média positiva em três anos e negativa em apenas um ano; porém, obtive ram heterobeltiose negativa nos quatro anos. Desse moào, os resultados obtidos estão de acordo com a maioria dos apresen tados na literatura revisada.

O carāter NIM apresentou média de $16,6 \pm 4,3$ internödios nos parentais, a qual foi extatamente igual à mé dia das progênies $F_{2}$, esta com menor erro padrão $(16,6 \pm 2,4)$. Esse carāter entretanto apresentou diferenças significativas ao nível de probabilidade de lo nos parentais e nas progênies $\mathrm{F}_{2}$. Os valores mais baixos de NIM foram observados naqueles parentais de crescimento determinado $[$ Forrest $(11,2)$, Hale $321(11,6)$, Paranā $(12,6)$ e Coker $136(13,4)]$. Os valo res maiores de NIM ocorreram nos parentais de crescimento in determinado, particularmente naqueles de crescimento mais pronunciado como IAC-Foscarin-31 $(22,4)$, Palmetto $(22,1)$ e Primavera $(21,1)$, os quais diferiram estatisticamente dos de mais. As variâncias obtidas a partir de dados transformados $(\sqrt{x+I})$ foram relativamente uniformes nos parentajs com média de $0,0711 \pm 0,0413$ (internöaios) ${ }^{2}$.

As progênies $F_{2}$ apresentaram variação de 12,3 internödios no cruzamento coker 136 x Hale 321 a 19,9 internódios no cruzamento Primavera x Década, variação que está 
entre os valores extremos dos parentais. Nas progênies $F_{2}^{\prime}$ ' entretanto, as variância tiveram média de 0,1716 $\pm 0,0749$ (in ternōdios) ${ }^{2}$ e variaram de 0,0567 no cruzamento Paraná x Forrest a 0,3301 no cruzamento IAC-Foscarin-31 x Hale 321. Portanto, existe variabilidade adequada no NIM para prática de seleção.

A heterose para NIM apresentou média de 2,9 \pm 16,1 e variou de $-41,2 * *$ no cruzamento Primavera $x$ Palemtto a 50,6\%** no cruzamento Forrest $x$ Hale 321 . Portanto, a hete rose tendeu a ser negativa entre parentais de crescimento in determinado, indicando que neste caso a progênie apresentou menor nümero de internódios que a média dos parentais; já no cruzamento entre parentais de crescimento determirado, a heterose tendeu a ser positiva, indicando que a progênie apresentou maior número de internódio que a média dos parentais. Entretanto, predominaram as estimativas positivas e embora as médias dos parentais e progênies $F_{2}$ tenham sido iguais, a mê dia da heterose positiva indica uma leve tendência de dominância para maior NIM.

As estimativas de heterobeltiose, entretanto, foram predominantemente negativas e em sua maioria significativas. A média foi de $-24,4 \pm 21,0 \%$ e variou de 0,0 no cruzamento FT $81-1835$ x SOC $81-79$ a $-66,8$ \%* no cruzamento IACFoscarin-31 x Haje 321. Esses resultados mostram que de um modo geral as progênies $\mathrm{F}_{2}$ colocaram-se entre a média dos pa rentais e o parental superior quanto a.o NIM. 
CAMPOS (1979) e KAW \& MENON (1979) obtiveram resultados semelhantes aos aqui apresentados para heterose e heterobeltiose para o carāter número de nōs. Por outro lado, VEATCH (1930) e WOODWORTH (1933) obtiveram valores relativamente mais altos para heterose e heterobeltiose positivas, resultados que não estão em acordo com os obtidos neste estudo. Entretanto, esses autores observaram um número muito pequeno de plantas, geralmente inferior a quatro por cruzamento, o que pode ter afetado a precisão das estimativas. CHEUDHARY \& SINGH (1974) tambëm obtiveram heterobeltiose positiva para o nümero de nōs, porēm a mëdia das observações foi relativamente baixa $(2,3 \%)$ e esses autores usaram espaçą mentos relativamente largos entre plantas dentro da fileira $(30 \mathrm{~cm})$ o que favorece a expressão do vigor de híbrido.

A APM teve uma média de $85,7 \pm 32,0 \mathrm{~cm}$ nos pa rentais e variou de 47,1 cm no cultivax Forrest a $139,7 \mathrm{~cm}$ no cultivar IAC-Foscarin-31. As variâncias da APM nos paren tais apresentaram una média de $142,4 \pm 170,2(\mathrm{~cm})^{2}$ e a penas irrês parentais apresentaram valores maiores que a variância mëdia: IAC-Foscarin-3I $\left(465,2 \mathrm{~cm}^{2}\right), \operatorname{sOC} 81-79\left(157,4 \mathrm{~cm}^{2}\right)$ e palmetto $\left(449,4 \mathrm{~cm}^{2}\right)$. Tais valores, princippalmente o primei. ro e o terceiro, sugerem que esses cultivares poderão não es tar totalmente homozigöticos para esses caracteres, ou então sofrem maior influência do ambiente.

As progênies $F_{2}$ a presentaram médìa de APM semelhante a dos parentais, mas com menor erro padrão 85,8 
$13,9 \mathrm{~cm})$. Entre essas progênies a altura variou de $58,4 \mathrm{~cm}$ no cruzamento coker 136 ,Forrest a $117,6 \mathrm{~cm}$ no cruzamento IACFoscarin-31 x Palmetto. Portanto, constata-se que as médias das progênies situaram-se entre os parentais de menor emaior altura. Entretanto, a média das variâncias em $F_{2}$ ' foi de $367,4 \pm 189,8 \mathrm{~cm}^{2}$, bastante superior à média àos parentais e variou de 63,9 no cruzamento FT 81-1835 x SOC 81-79. a 672,3 $\mathrm{cm}^{2}$ no cruzamento Forrest x FT 81-1835. Vale salientar que o cruzamento IAC-Foscarin-3l x Palmetto que apresentou a maior média de altura, apresentou também uma das maiores variâncias $630,2 \mathrm{~cm}^{2}$. Portanto, esses dados motram que o conjunto de parentais reune uma considerável variabildiade para APM.

A maioria das estimativas de heterose foram positivas. Apresentaram média de 6,0 $\pm 28,9 \%$ e ampla faixa de variação, indo de $-60,1 \% * *$ no cruzamento IAC-Foscarin - 31 $\mathrm{x}$ Forrest a 111,0\%** no cruzamento Forrest $\mathrm{x}$ Hale 321 . Um dado importante a observar é que em todos os cruzamentos em que o parental. IAC-Foscarin-3l participou, a heterose foi ne gativa, evidenciando que neste caso a média da progênie $F_{2}$ foi inferior à média dos parentais. Heterose positiva tem sido constatada por vários autores (CAMPOS, 1979; CHAUHAN \& SINGH， 1982; KUNTA et 23i主, 1.985; VEATCH, 1930; WEBER et alii, 1970; WENTZ \& STMWART, 1924; WOODWORTH, 1933). Apenas o trabalho de KAW \& MENON (1979) apresentou heterose média ne gativa pare a APM. Evidentemente esse é um resultado possí 
vel de ser obtido. Entretanto, o que parece ser mais freqüente pela literatura consultada é a ocorrência de heterose positiva para APM.

As estimativas de heterobeltiose foram em sua maioria negativas, apresentaram uma mëdia de $-27,5 \pm 35,0 \%$ e variaram de $-105,5 \% * *$ no cruzamento IAC-Foscarin-31 x Forrest a $94,9 \%$ no cruzamento Forrest $x$ Hale 321. Na literatura há trabalhos em que tambëm foram obtidas heterobeltioses médias negativas (CAMPOS, 1979; KAW \& MANON, 1979; WEBER et aIil, 1970). Há também trabalhos em que foram obtidas heterobeltioses mëdias positivas (KUNTA et alii, 1985; VEATCH, 1930 ; WOODWORTH, 1933). Nestes trabalhos, dois aspectos chamam a atenção: no primeiro trabajho foi usado um espaçamento muito largo e nos dois ültimos foram observadas poucas plantas, ge ralmente menos de quatro. Talvez esses dois fatores tenham contribuído para uma superestimação do hỉbrido.

PASCHAI II \& WILCOX (1975) relataram que as pro gênies $F_{1}$ tenderam a ser intermediárias entre os parentais. Neste estudo tambëm chegou-se a esse resultado, podendo-se di zer mais especificamente que as progênies $\mathrm{F}_{2}$ tenderam a situar-se entre a média dos parentais e o parental superior, quanto à APM. Exceção feita aos cxuzamentos que envolveram - parental IAC-Foscarin-3I. 


\subsubsection{Acamamento e valor agronômico}

Os dados referentes à média, variância, hete rose e heterobeltiose para os caracteres Ac e VA são apresentados na Tabela 14 .

Esses dois caracteres têm em comum a avaliação subjetiva através de uma escala de notas e a análise realizada com dados transformados para $\sqrt{\mathrm{x}+1}$.

E importante Iembrar que para Ac as menores notas correspondem aos menores graus de Ac e portanto, a um melhor comportamento. Entre os parentais a média de Ac foi de $1,3 \pm 0,5$ e variou de 1,0 no cultivar Década a 2,5 no cultivar IAC-Foscarin-31. A média da variância nos parentais foi de $0,0158 \pm 0,0173$ e os cultivares soc 81-79 e IACFoscarin-31, foram os que apresentaram as maiores variâncias, respectivamente 0,0556 e 0,353 .

Nas progênies $\mathrm{F}_{2}$ a mêdia do Ac foi $:$ de $1,2 \pm 0,2$ e variou de 1,0 nos cruzamentos Paraná x coker 136, Coker 136 x Hale 321 e Dëcada x FT 81-1835 a 2,1 no cruzamen to IAC-Foscarin-3I x Palmetto. Nas progênies $F_{2}$, foi em mê dia 0,0240 $\pm 0,0196$ e justamente o cruzamento IAC-Foscarin $31 \times$ Palmetto foi o que apresentou a maior variância $(0,0849)$.

As estimativas de heterose, em sua maioria, foram negativas e apresentaram uma média de $-11,3 \pm 24,6 \%$ 을 rëm, apenas quatro estimativas foram significativas, nos cru 
zamentos IAC-Foscarin-31 x Coker 136, IAC-Foscarin-31 x Forrest, IAC-Foscarin-31 x FT 8I-1835 e IAC-Foscarin-31 x Ha le 321 , respectivamente com valores de $-74,1$ *; $-111,2$ **; $-70,9$ * e $-76,4 \%$. Esses resultados mostram que as progênies tenderam a apresentar menor grau de Ac que a média dos respectivos parentais. PASCHAL II \& WILCOX (1975) afirmam que en seus resultados as progênies $F_{I}$ tenderam a ser intermediārias entre os parentais e que apenas um cruzamento apresentou $F_{1}$ mais resistente ao Ac que a média dos pa rentais.

As heterobeltioses estimadas em relação ao pa rental mais resistente, portanto em relação ao que apresentou escore mais baixo, em suá maioria foram positivas, com média de $25,0 \pm 30,0 \%$. Neste caso, seria mais importante que a heterobeltiose fosse negativa, o que significaria que as progênies $\mathrm{F}_{2}$ seriam mais resistentes ao Ac que $O$ parental mais resistente. Entretanto, apenas seis cruzamentos apresentaram heterobeltiose negativa, nenhuma por ër, significativa. O valor de maiox magnitude foi $-28,2 \%$, apresentado pelo cruzameento SOC 81-79 x Palmetto. Esse cruzamento revela, portanto, um certo potencial para resistência aO AC. PASCHAL II \& WILCOX (1975) relatam que também ño obtiveram nenhuma $F_{I}$ que superasse o parental mais resistente.

Esses resultados mostram, portanto, que as 
progênies $F_{2}$ tenderam a ser mais resistentes que a média dos parentais, mas foram menos resistentes que o respectivo parental mais resistente. Porém, pela magnitude da variância média dessas progênies evidencia-se que há variabilidade pa ra se efetuar seleção para maior resistência ao Ac.

Para OVA, embora o teste "F" tenha sido significativo ao nível de probabilidade de 5\%, não foi constata da diferença entre as médias dos parentais pelo teste Tukey. A média dos parentais foi de $2,4 \pm 0,3$ e houve uma variação de 1,9 no cultivar IAC-Foscarin-31 a 2,7 no cultivar prima vera. A média das variâncias foi de 0,0437 $\pm 0,0180$,variando de 0,255 nos parentais coker 136 e Hale 321 a 0,0821 no cultivar SOC $81-79$.

Entre as progênies $F_{2}$ houve diferença significativa (1\%) para $\circ \mathrm{VA}, \circ$ qual apresentou média de $2,4 \pm 0,2$, e variou de 1,8 no cruzamento FT 81-1835 x Hale 321 a 2,8 nos cruzamentos Paraná x soc 81-79 e Primavera x Década. A média das variâncias foi de 0,0602 $\pm 0,0180$,a qual variou de 0,0277 no cruzamento Paraná x Primavera a 0,1080 no cruzamento IAC-Foscarin-31 x Palmetto. Esses resultados sugerem que há uma ampla varíabilidade genëtica para esse carāter.

o nümero de estimativas de heterose negativa foi um pouco superior ao das estimativas positivas e a média foi de $1,5 \pm 20,4 \%$, entretanto, apenas seis estimativas fo- 
ram significativas, sobressaindo-se as estimativas positivas de 59,5\%* no cruzamento IAC-Foscarin-3l x Coker 136 e 43,2\%* .. no cruzamento IAC-Foscarin-31 x FT 81-1835. As estimativas de heterobeltiose foram en sua maioria negativas e apresentaram mêdia de $-13,4 \pm 17,9 \%$. Detectaram-se sete estimativas significativas, porēm apenas uma positiva, 30,6\%* no cru zamento IAC-Foscarin-31 x FT 81-1835. Esses resultados mostram que o VA das progênies girou enn torno da média dos parentais com uma leve tendência para ser inferior; en sua maioria o VA da progênie foi menor que o VA do respectivo pa rental superior. Por outro lado, mostram que há uma granàe variabilidade para esse caráter.

Na realidade, o VA expressa o resultado do em prego de um índice mental que reflete o valor global de uma planta ou progênie. E portanto o resultado de uma avaliação visual simultânea de uma série de caracteres agronômicos, o qual è expresso através de uma nota. BRIM (1973) relatou que esquemas de avaliação visual são efetivos para caracteres de alta herdabilidade e que têm sido usados para reduzir a quan tidade de progênies para um nümero que permita uma avaliação do potencial de produtividade. Levando em consideração essas afixmações, é provāvel que o VA como foi usado neste trabalho, principalmente por ter sido empregado em $\mathrm{F}_{2}$, não tenha uma boa eficiência para fins de seleção. Nessa geração há ainda uma considerável ação da heterose e nestes casos a avaliação visual poderă refletir, pelo menos 
em parte, o vigor de híbrido, que geralmente não se mantēm através do processo de avanço de gerações em direção à ho- : mozigose.

\subsubsection{Produtividade}

o caráter produtividade foi avaliado através do peso de grãos de duas maneiras: produtividade de plantas individuais (PPI) amostradas na parcela e produtividade da parcela (PP). A média, variância, heterose e heterobeltiose para essas duas avaliações são apresentadas na. Tabela 15.

Na PPI, tanto parentais quanto progênies $F_{2}$ apresentaram diferenças significativas ao nîvel de probabili dade de 1\%. A média de produtividade dos parentais foi $38,5 \pm 10,1 \mathrm{~g} / \mathrm{planta}$ e variou de 24,8 no parental FT 81-1835 a $54,5 \mathrm{~g} / \mathrm{planta}$ no parental soC 81-79, o qual não diferiu es tatisticamente dos parentais IAC-Foscarin-3l, Palmetto e Forrest. As variâncias dos parentais tiveram média de $272,0 \pm 137,9$ (g/planta $)^{2}$. As maiores variâncias foramapresentadas pelos parentais IAC-Foscarin-31, Primavera e SOC 81-79, respectivamente 416,$5 ; 413,7$ e 453,6 (g/planta) ${ }^{2}$.

Entre as progênies $F_{2}$, a PPI a presentou médj.a de $38,9 \pm 8,1 \mathrm{~g} / \mathrm{planta}$, a qual não diferiu estatisticamente da média dos parentais. Cinco progênies $\mathrm{F}_{2}$ apresentaram média de produtividade entre 20 e $30 \mathrm{~g} / \mathrm{planta}, 21$ entre 30 e $40 \mathrm{~g} / \mathrm{planta}, 16$ entre 40 e $50 \mathrm{~g} / \mathrm{planta}$ e três produziram aci 
ma de $50 \mathrm{~g} / \mathrm{planta.} \mathrm{No} \mathrm{total,} 23$ progênies superaram a média dos parentais e duas superaram o parental mais produtivo do grupo, respectivamente as progênies dos cruzamentos primavera x FT 81-1835 (58,5 g/planta) e IAC-Foscarin-31 x Forrest $(58,1 \mathrm{~g} / \mathrm{planta})$. A média das variâncias das progênies foi de $354,8 \pm 167,0$. O cruzamento IAC-Foscarin-31 x Palmetto, o terceiro em produtividade $(52,2 \mathrm{~g} / \mathrm{planta})$, foi o que apresentou maior variância $(870,5)$. O segundo cruzamento em pro dutividade (IAC-Foscarin-31 x Forrest) apresentou tambëm a segunda maior variância 720,6 (g/planta $)^{2}$.

As estimativas de hețerose variaram de $-52,5 \% * *$ no cruzamento Forrest x SOC $81-79$ a $184,4 \% *$ no cruzamento Pri mavera x FT 81-1835 e tiveram uma média de 5,2 $238,0 \%$ Ape nas sete estimativas foram significativas e destas apenas quatro foram positivas $43,2 * ; 46,8 * ; 184,4 *$ e $61,7 *$, respectivamente nos cruzamentos IAC-Foscarin-3I x Forrest, IAC-FOS carin-31 x FT 81-1835, Primavera x F'T 81-1835 e Primavera x Hale 321.

As estimativas de heterobeltiose foram predominantemente negativas com mëdia de $-22,2 \pm 35,1 \%$ Entre os poucos cruzamentos que apresentaram heterobeltiose positiva, apenas Primavera x Forrest apresentaram resultado significativo $(125,0 \% * *)$. Esses resultados mostram que as progênies $F_{2}$ distribuiram-se amplamente em torno da mêdia dos parentais com uma pequena tendência de superioridade; porém, a 
maioria das progênies $\mathrm{F}_{2}$ foram inferiores ao respectivo parental superior.

Na avaliação da PP, a exemplo do que ocorreu para PPI, houve diferenças significativas a 1\% entre parentais e entre progênies $F_{2}$ A PP média dos parentais foi de $2502 \pm 659 \mathrm{~kg} / \mathrm{ha}$. Os dois parentais mais produtivos foram IAC-Foscarin-3l e Palmetto, respectivamente com valores de 3777 e $3424 \mathrm{~kg} / \mathrm{ha}$, os quais não diferiram estatisticainente entre si e confirmaram os bons níveis observados na PPI. De pois destes parentais, classificaram-se os cultivares Paraná e Década, respectivamente com PP de 2672 e 2546 kg/ha, os quais só diferiram significativamente do ūltimo colocado (Forrest com $1577 \mathrm{~kg} / \mathrm{ha}$ ).

Entre as progênies $F_{2}$ a média de PP foi $2562 \pm$ $457 \mathrm{~kg} / \mathrm{ha}$, a qual nãu diferiu significativamente da média dos parentais. Três progênies $F_{2}$ produziram entre 1000 e $2000 \mathrm{~kg} / \mathrm{ha}, 32$ entre 2000 e $3000 \mathrm{~kg} / \mathrm{ha}$ e 10 entre 3000 e $4000 \mathrm{~kg} / \mathrm{ha}$. No total, 23 progênies $F_{2}$ produziram acima da média dos parentais, porërn, nenhuma progênie produziu mais que o parental. mais produtivo do grupo. Das 20 melhores pro gênies $\mathrm{F}_{2}$, superiores em PPI, 13 foram incluídas entre as 20 melhores arn PP.

As estimativas de heterose para PP variaram de $-99,7 \% * *$ no cruzamento IAC-Foscarin-31 x Forrest a 103,4\%** no cruzamento Forrest $x$ Hale 321 e tiveram mëdia de $8,4 \pm$ 
39,98. Foram detectadas 21 estimativas significativas de heterose das quais apenas 13 foram positivas, sobressaindo-se as observadas nos cruzamentos Paranā x SOC 81-79, Primavera x SOC 81-79, Forrest x Hale 321 e FT 81-1835 x Palmetto, respec tivamente $73,7 * * ; 60,3 * * ; 103,4 * *$ e $60,3 * *$. As estimativas de heterobeltiose apresentaram média de $-16,6 \pm 37,9$ e variaram de $-128,9 \% * *$ no cruzamento IAC-Foscarin-31 * Hale 321 a $71,5 \% * *$ no cruzamento Forrest $x$ Hale 321. Apenas très cruzamen tos apresentaram heteroneltiose positiva e significativa, Paraná x SOC 81-79, Primavera x SOC 81-79 e Forrest x Hale 321 , respectivamente com $67,9 * * ; 47,5 *$ e $71,5 \% * *$. Portanto, a maioria das progênies $F_{2}$ produziu mènos que o respectivo parental superior.

Neste estudo, em termos ảa mëdia de tołos cs cruzamentos, tanto os dados de heterose como os de heterobeltiose para PPI e PP, foram relativamente concordantes. Ambos os va lores mëdios de heterose foram positivos e ambos ae heterobel tiose foram negativos. Na literatura consultada todos os resultados módjos de heterose, geralmente obtidos a partir da produtividade em gramas/planta, são positivos e apresentam uma grande variação. CAMPOS (1979) obteve méảia de 19,0\%; CHAUHAN \& SINGH (1982)，48,4\%; MEHTA et aIii (1984)，24,6\%; VEATCH (1930) 35,5\%; WEBER et alii (1979), 25,1\%; WENTZ \& STEWART (1924), 171,8\% e WOODWORTH (1933), 93,7\%. Os valores médios de $5,3 \%$ e $8,4 \%$ observados respectivamente para PPI e PP são pequenos em relação aos da literatura. 
Para heterobeltiose, os resultados da literatura são também positivos. CAMPOS (1979) obtéve média de :3,3\%; CHAUDHARY \& SINGH (1974), 26,1\%; MEHTA et alii (1984) $57,8 \%$; KAW \& MENON (1979), 4,3\%; KUNTA et alii (1985) 20,1\%; PASCHAL II \& WILCOX (1975), 8,0\%; VEATCH $(1930), 19,5 \%$; WEBER et alii (1970), 13,4\% e WOODWORTH (1933), 30,9\%. A mëdia da heterobeltiose foi negativa tanto pata PPI $(-22,2 \%)$ co mo para PP $(-16,6 \%)$. Porém, tanto para heterose como para heterobeltiose, particularmente para PP, que envolveu uma amos tragem maior de plantas, alguns cruzamentos apresentaram valores positivos e significativos: Paraná x SOC 81-79, Década x SOC 81-79 e Forrest $x$ Hale 321, respectivamente $73,7 * *$; $60,3 * *$ e $103,4 \% * *$ para heterose; $67,9 * * ; 45,5 *$ e $71,5 \% * *$ para heterobeltiose.

Vale ressaltar que apenas duas progènies $\mathrm{F}_{2}$ superaram o melhor parental do grupo em PPI (IAC-Foscarin- 31 x Forrest e Primavera x FT 81-1835) porém não confirmam esse potencial quando foi considerado a PP. Na avaliação da PP, nenhuma progênie superou o parental mais produtivo do grupo (IAC-Foscarin-3I). Portanto, se esse cultivar fosse tomado como referência, não seria constatada heterose padrão para PP.

WEBER et al11 (1970), PASCHAL II \& WILCOX (1975) e KUNTA et alii (1985) afirmaram que para que haja sucesso na exploração comercial de híbridos en soja, dois re-quisitos devem ser atendidos: a) heterose para produtividade; 
mais precisamente deve existir heterose padrão para que o híbrido seja mais vantajoso que os cultivares homozigóticos disponíveis; b) um método para produção de sementes híbridas em larga escala deve ser desenvolvido. Esta segunda exi gência é talvez a curto prazo a maior barreira para a exploração do vigor do híbrido em soja (NELSON \& BERNARD, 1984). Entretanto, BURTON \& CARTER (1983) jā propuseram um método para produção de sementes híbridas de soja em quantidades ex perimentais. Isso significa que um passo inicial já foi dado e o uso do vigor de híbrido em soja pode vir a se tornar uma prātica comum no futuro.

Relacionando-se a PPI com a PP dos parentais constata-se que SOC 81-79 e Forrest sofreram marcante altera ção de posição de uma avaliação para outra; tendo sido primeiro e quarto colocados em PPI, passaram respectivamente pa ra sétimo e décimo colocados em PP. O coeficiente de correlação de sperman ou ordinal ( $r_{S}$; SNEDECOR \& COCHRAN, 1977) entre as duas avaliações foi 0,42 (não significativo) para o grupo dos dez parentais; entretanto, quando os parentais SoC 81-79 e Forrest foram excluídos obteve-se $r_{s}=0,71$ (signifi cativo a 5\%). Pelo menos cinco progênies $\mathrm{F}_{2}$ sofreram mudanças marcantes de classificação com base em PPI e PP. As pro gêneis $\mathrm{F}_{2}$ dos cruzamentos Primavera y FT 81-1835, IAC-Foscarin-31 x Forrest, IAC-Foscarin-31. x FT 81-1835, Dëcada x Pal metto e Paranä x Palmetto, que ocuparam as posições, primeira, segunda, sexta, nona e quadragésima terceira na avalia- 
ção da PPI, passaram respectivamente para quadragésima terceira, quadragésima quinta, quadragésima primeira e décima segunda colocadas na PP. Para O conjunto de 45 progênies $F_{2}$ ' estimou-se $r_{s}=0,23$ (não significativo) entre as classificações de PPI e PP; esta correlação passou para $r_{S}=0,52$ (significativo a l\%) quando foram excluíảas as cinco progênies $\mathrm{F}_{2}$ antes mencioandas. Estes dados evidenciam que, provavelmente em alguns casos houve superestimação. ou subestimação da PPI, enquanto que em outros houve subestimação da PP. Neste caso, pode-se citar como exemplo as progênies dos cruzamentos JAC-Foscarin-31 x Forrest, IAC-Foscarin31 x FT 81-1835 e Primavera x FT 81-1835, com produtividades relativamente mais baixas que as das demais progênies de am-bos os parentais.

A explicação para mudança marcante de classificação è a ocorrência de perdas de estande. Como a soja tem boa capacidade de compensação, o estande baixo leva à su perestimação da PPI e à subestimação de PP, de maneirra que se obtën grandes produtividades nas amostras de plantas individuais e baixa produtividade da parcela. Isso foi verifi cado na maioria dos casos citados. Entretanto, vale salientar que as perdas de estandes mais ou menos constantes através das repetições foram encaradas como uma característica do parental ou do cruzamento. 
veis sub ou superestimações de produtividade, os coeficientes de variação das análises de variância de PPI e PP foram respectivamente de 20,6 e $15,9 \%$ (Tabela 11), os quais estão en : um nível satisfatório para trabalhos realizados em campo e refletem a boa precisão do experimento. Em outras palavras, pode-se admitir que os possiveis desvios occrridos não ti veram uma magnitudesuficiente para comprometer a precisão do experimento.

Considerando os resultados obtidos para produ tividade e outros caracteres (Tabelas 12, I3, 14 e 15), as diferenças significativas observadas entre parentais e principalmente entre progênies $\mathrm{F}_{2}$ e, além disso, a amplitude de variação da heterose e da heterobeltiose, constata-se que es se grupo de parentais reune uma considerável variabilidade para todos os caracteres avaliados e particularmente para produtividade que è o caráter para o qual se concentram as maiores atenções.

\subsection{CoRrelagões entre caracteres}

As correlações estimadas para os parentais e para as progênies $F_{2}$ são apresentadas na Tabela 16.

Com raras exceções, tanto nos parentais quan to nas progênies $\mathrm{F}_{2}$ as correlações genotípicas tiveram o mes mo sinal e foram maiores que as fenotipicas; ambas foram geralmente superiores às respectivas correlações de ambiente. 
Correlações genotípicas com sinal igual e valores maiores que as fenotípicas têm sido comuns em soja (ANAND \& TORRIE, 1963; BYTH et alii, 1969; CAVINESS et alii, 1968; FEHR \& WEBER, 1968). Embora sendo os parentais homozigóticos e as progênies $\mathrm{F}_{2}$ heterozigōticas, portanto tendo diferentes componentes da variância genética, as correlações genotípicas e fe notipicas foram bastante concordantes nos dois grupos de ma teriais.

Nos dois grupos, a PP, mostrou-se positivamen te correlacionada com NDM, NIM, APM e AC. Correlações positivas da produtividade com NDM, APM e AC foram também consta tadas por ANAND \& TORRIE (1963), JOHNSON et aIii (1955)), KNOW \& TORRIE (1964) e SIMPSON \& WILCOX (1983). Corre]ação da PP com o nümero de nós foi relatada por CAMPos (1979) e SIMPSON \& WILCOX(1983). Para PPI, todas essas correlações foram positivas e relativamente altas $(>0,50)$, com poucas ex c eções.

Embora tenha havido correlação positiva entre PP e PPI, as estimativas foram geralmente baixas, particular mente nas progênies $F_{2}$. Isso sugere que pelo menos em alguns tratamentos as avaliações não foram satisfatoriamente concordantes. Esse resultado confirma o que foi constatado pelo coeficiente de correlação de sperman ou ordinal ( $s_{s}$ ), apresentado no item 4.2.4, entre as médias desses dois carac teres. 
As correlações da PP e da PPI com os caracteres relacionados ao florescimento, geralmente foram baixas. Occrreu exceção para APF das progènies $F_{2}$, cujos coeficientes de correlação fenotípica e genotípica com produtividade tiveram "valores absolutos relativamente altos, porém negativos.

As correlações da PP com o VA foram baixas, tanto nos parentais quanto nas progênies $\mathrm{F}_{2}$, sendo a correla ção genotípica negativa nos dois grupos. Na realidade, a ausência de correlação significativa entre esses äois caracteres não è muito surpreendente, uma vez que o valor agronômico è um caráter complexo e não foi avaliado ao nível de parcela. Por outro lado, as correlações entre PPI e VA foram positivas nos dois grupos, porëm foram de pequena magnitude nos parentais. BYTH et alii (1969) usaram um escore similar ao VA para avaliar linhagens experimentais em $F_{6}$ : e $\mathrm{F}_{7}$ e obtiveram correlações fenotípicas positivas (na maioria dos casos significativas) com a produtividade. Contudo, as correlações genotípicas foram baixas. Esses resultados suge rem que o VA pode ser útil no processo de avaliação preliminar de produtividade; talvez a eficiência do VA possa ser melhorada usando-se mais de um avaliador e utilizando-se a média das avaliações como resultado final.

Os caracteres NDF, NIF e APF apresentaram COㅌ relações fenotípicas e genotípicas positivas entre si. Con- 
tudo, apresentaram baixas correlações com outros caracteres, à exceção da correlação negativa entre PPI e APF observada nas progènies $\mathrm{F}_{2}$. Esses resultados sugerem que nesse grupo de materiais precoces os caracteres avaliados no florescimen to, em época normal de plantio, não parecen ter grande impor tância no processo de seleção. FARIAS NETO (1987), entretan to, concluiu que os caracteres NDF e APF são importantes no melhoramento da produtividade em cultivo de invernoe en baixas latitudes.

Os caracteres relacionados com o desenvolvi mento da planta na maturidade (NDM, NIM, APM) apresentaram correlações positivas e altas entre si e com PPI, PP, Ac e $V A$, tanto nos parentais quanto nas progênies $\mathrm{F}_{2}$. Portanto, esses caracteres mostraram-se bastante importantes para o processo de seleção desse material precoce. Tais resultados estão de acordo com os obtidos por ANAND \& TORRIE (1963), JOHNSON et alii (1955b) e kNOW \& TORRIE (1964), com poucas exceções .

Como era esperado as correlações fenotípicas e genotípicas entre VA e Ac foram todas negativas, sendo tam bérn de pequena magnitude nos parentais e progênies $F_{2}$.

Conforme já foi mencionado, a grande maioria das correlações de ambi ente foram de pequena magnitude. No grupo de parentais, apenas as correlações entre PPI e VA, $A P F$ e APM, Ac e VA, foram maiores que as correlações genotípicas e fenotípicas, tendo sido todas elas maiores que 0,5 (valor absoluto). No grupo das progênies $\mathrm{F}_{2}$, seis correla- 
Ções de ambiente foram superiores às correlações genotípicas e fenotípicas: PPI e APM; PPI e VA; NDF e NDM; NIF e NIM; APT e APM; e APM e AC.

Esses resultados sugerem que a ação do ambien te atuou no mesmo sentido na expressão desses caracteres e foi relativamente mais importante que ação genética na associação entre eles. Nos dois grupos, várias correlações de ambiente apresentaram sinais contrários ao das correlações genotípicas e fenotípicas, sugerindo que a ação do ambiente foi em sentido contrário ao da ação genética nesses caracteres. Essas constatações em termos práticos são muito importantes porque, dependendo da magnitude da ação do ambiente, podem comprometer a eficiência da seleção.

A partir desses resultados constata-se que os caracteres relacionados à maturidade mostram-se, dentre os estudados, como os mais importantes no melhoramento para pro dutividade. Porén, a correlação alta e positiva entre NDM e produtividade constitui um fator de dificuldade, quando o ob jetivo for a obtenção de materiais produtivos e precoces. Neste caso, a seleção terá sentidos opostos nos dois caracte res e será dificultada fela correlação positiva entre eles.

\subsection{ANÁLIse dialélica de hayman}

4.4.1. Teste de validade do modelo

Para experimentos com repetições, dois testes 
fornecem em conjunto uma melhor informação sobre o tipo de relação existente entre as variâncias $\left(V_{i}\right)$ e as covariâncias $\left(C_{i}\right)$ das linhas (i) da tabela dialélica: a) análise da variância das diferenças $\left(C_{i}-V_{i}\right)$ (conjunto de progênies do iésimo parental recorrente), b) coeficeinte de regressão b de $c_{i}$ sobre $v_{i}$ (MATHER \& KINKS, 1982). Quando as diferenças $\left(C_{i}-V_{i}\right)$ das linhas são homogèneas e b não difere significati vamente da unidade o modelo é considerado suficiente, ou se ja, o caráter em estudo pode ser explicado através do modelo aditivo-dominante. Além da anālise das diferenças $\left(C_{i}-v_{i}\right)$ foram realizadas as análises de $v_{i}$ e $C_{i}$ individualmente e das somas $\left(C_{i}+V_{i}\right)$; porém, a maior atenção foi dada para as diferenças $\left(c_{i}-v_{i}\right)$.

Nas análises incluindo os dez parentais, os cararteres NDF, APF, NIM, APM, VA e PPI apresentaram hoterogeneidade para as diferenças $\left(C_{i}-V_{i}\right)$. o caráter Ac, embora apresentando homogeneidade para as diferenças $\left(C_{i}-v_{i}\right)$ te ve o coeficiente de regressão b não diferente de zero. Para esses caracteres realizaram-se novas análises excluindo dife rentes parentais, ou seja, de dialelos $(n-1) \times(n-1)$ e em alguns caracteres $(n-2) \times(n-2)$, como recomenda HAYMAN (1954b). Apenas ros caracteres APM, VA e AC não se conseguiu homogenei dade para as diferenças $\left(C_{i}-V_{i}\right)$. Contudo, a significância das diferenças $\left(C_{i}-V_{i}\right)$ nesses caracteres ocorreu apenas ao nivel de probabilidade de 5\% (Tabela 17). 
Vale observar que geralmente para os caracteres em que as diferenças $\left(c_{i}-v_{i}\right)$ foram homogêneas, $c_{i}$ e $v_{i}$ e as somas $\left(C_{i}+v_{i}\right)$ também tenderam a ser homogêneas. Ocorreu exceção para PP, onde apesar das diferenças $\left(C_{i}-v_{i}\right)$ serem homogêneas, $v_{i}, c_{i}$ e as somas $\left(c_{i}+v_{i}\right)$ foram heterogèneas. A significância de $\left(c_{i}+v_{i}\right)$ é decorrente das diferenças entre as progênies dos parentais recorrentes e sugere a presença de efeitos de dominância (MATHER \& JINKS, 1982).

o segundo teste de validade do modelo baseouse na regressão de $C_{i}$ sobre $v_{i}$, a qual no modelo aditivo-dominante deve apresentar o coeficiente de regressão $b \simeq 1$. De acordo com a Tabela 18, para a maioria dos caracteres, os va lores de b foram superiores a 0,50; ocorreu exceção para APF com $b=0,46$. De um modo geral, os desvios $\left(s_{b}\right)$ tambëm foram relativamente baixos; en todos os caracteres a magnitude do desvio foi menor que a metade da estimativa do parâmetro. Os coeficientes de determinação $\left(R^{2}\right)$ apresentaram valores su periores a 0,50 , com exceção da $\operatorname{PPI}\left(R^{2}=0,42\right)$. Para todos os caracteres o teste "t" foi significativo para a hipótese $\mathbf{b}=0$. Para a hipótese $\mathbf{b}=1$, nos caracteres APF e Ac o tes te " $t$ " mostrou significância (5\%); para os outros oito carac teres o teste "t" não foi significativo.

Outros autores também verificaram que o modelo aditivo-dominante não foi suficiente para explicar as observações de alguns caracteres: PPI, NDF e APM (LEFFEL \& 
WEISS, 1958); produtividade, APM, nưmero de nós e nưmero de ramos (KAW \& MENON, 1983). Caracteres como NDF, APM e PPI que en vārias pesquisas não obedeceram ao modelo aditivo-domi nante devem ter um tipo de ação gênica mais complexa, talvez envolyendo epistasia.

Em certos caracteres a heterogeneidade foi provocada por alguns parentais em particular, pois com a exclusão destes a heterogeneidade foi anulada ou, pelo menos, minimizada. Os seguintes parentais e caracteres mostraram este tipo de comportamento: Década para NDF, Primavera e Dëcada para APF e NIM, Coker 136 e Forrest para APM e FT 81-1835 para PPI. Portanto, esses cultivares de algum modo estavam contribuindo para que, nos respectivos caracteres, uma ou mais restrições da metodologia não fossem atendidas.

Apenas para os caracteres APM, VA e Ac que apresentaram diferenças $\left(C_{i}-V_{i}\right)$ significativas a $5 \%$ e APF com a hipótese $b=1$ significativa a 5\%, as anālises são a pe nas aproximadas. Vale salientar que para o caráter Ac, as tentativas de exclusão de parentais não alteraram a heteroge neidade das diferenças $\left(C_{i}-V_{i}\right)$.

\subsubsection{Anälise gräfica}

Após serem realizados os testes de validade do modelo aditivo-dominante, a partir da regressão de $c_{i}$ so- 
bre $v_{i}$ foram feitos os estudos gráficos da genética dos caracteres (JINKS, 1954; HAYMAN, 1954b; SINGH \& SINGH, 1984a), cujos resultados são discutidos a seguir.

\subsubsection{Caracteres relacionados ao florescimento}

Os gráficos dos caracteres NDF, NIF e APF são apresentados na Figura 3. O caráter NDF (Figura 3a) a presentou $\mathbf{b}=$ $1,0386 \pm 0,2068$, o qual não diferiu significativamente da unidade, $\mathbf{A}=1,8607$ e $R^{2}=0,7899$; este valor de $b$ sugere que houve um bom ajuste dos dados à reta de regressão. O ponto no qual a reta tangente à parábola intercpeta o eixo das covariâncias $\left(C_{i}\right)$ teve o valor $\mathbf{B}=4,5882$. A relação $2[\mathrm{RB} / \mathrm{OB}]^{0,5}$ que fornece o grau médio de dominância teve um valor de 1,5420 que evidencia a ocorrência de sobredominância. A correlação entre $Y_{i}$ e $\left(C_{i}+V_{i}\right)$ apresentou 0 valor ce $r=-0,0140$, que não difere de zero. Para a geração $F_{1}$ KAW \& MENON (1983), LEFFEL \& WEISS (1958) e TOLEDO \& KIIHL (1982b) obtiveram dominância parcial para esse caräter. Além disso, o baixo valor e o sinal negativo da correlação entre $Y_{i}$ e $\left(C_{i}+V_{i}\right)$ não estão de acordo com os obticios por KAW \& MENON (1983) e TOLEDO \& KIIHL (1982 b), Os quais foram respectivamen te de 0,74 e 0,95, resultados que significam que os genes do minantes reduzem a expressão do caräter. Possivelmente essa correlação negativa e próxima de zero seja decorrente do fato deste estudo incluir somente genótipos precoces. Apesar 
disso, a partir do gráfico da regressão de $C_{i}$ sobre $V_{i}$ constata-se que o cultivar Primavera é o que contém mais genes dominantes e que Palmetto, Hale 321, Forrest, FT 81-1835 e Paraná contém mais genes recessivos; os demais cultivares si tuam-se intermediariamente.

No carāter NIF (Figura 3b) a reta de regressão interceptou o eixo das covariâncias abaixo da origem $(A=-0,0003)$, indicando a ocorrência de sobredominância. 0 coeficiente de regreşão $b=0,9428 \pm 0,3148$ não diferiu sig nificativamente da unidade. A reta tangente à parábola interceptou $O$ eixo das covariâncias em $B=0,0125$. O grau mëdio de dominância foi de 2,0248. O ajuste dos pontos à regressão foi apenas razoável com $\mathrm{R}^{2}=0,5328$. O coeficiente de correlação entre $Y_{i}$ e $\left(C_{i}+V_{i}\right)$ foi de $r=0,167.8$, não sig nificativo. Os cultivares Primavera, Coker 136, IAC-Foscarin-31 e Hale 321 são os que apresentaram o maior número de genes dominantes e os cultivares Década e soc 81-79 os que contēm maior número de genes recessivos. KAW \& MENON (1983) para o nümero de nós, obtiveram em $F_{1}$ ảominância parcial e para a correlação entre $Y_{i}$ e $\left(C_{i}+V_{i}\right)$ obtiveram também um va lor negativo. Embora não se tratando da mesma geração e nem especificamente da mesma determinação, os resultados são até certo ponto concordantes, particularmente no que se refere ao sinal de correlação entre $Y_{i}$ e $\left(C_{i}+V_{i}\right)$.

A APF (Figura 3c) atendeu ao modelo aditivodominante no que se refere a homogeneidade das diferenças 
$\left(C_{i}-V_{i}\right)$, mas, apresentou $b=0,4586 \pm 0,1806$, o qual diferiu de zero e da unidade a 5\%. Desse modo, os resultados da anălise da APF são apenas aproximados. A reta de regressão interceptou o eixo das covariâncias em $\mathbf{A}=18,4023$ e a reta tangenteà parābola em $\mathbf{B}=45,4705$. o grau médio de dominância obtido a partir do gráfico é portanto de 1,5431. A correlação entre $Y_{i}$ e $\left(C_{i}+v_{i}\right)$ foi de 0,2499 (não significativa). KAW \& MENON (1983) obtiveram na geração $\mathrm{F}_{1}$ grau médio de dominância 0,60 e $r=0,76$ para a correlação $Y_{i}\left(c_{i}+v_{i}\right)$. Embora tratando-se de gerações dife rentes, o grau médio de dominância é bastante concordante e a correlação entre $Y_{i}$ e $\left(C_{i}+V_{i}\right)$ apresentou o mesmo sinal. Os cultivares com maior número de genes dominantes foram 0 Hale 321, Coker 136 e FT 81-1835; os cultivares com maior número de genes recessivos foram Forrest e Palmetto; os demais ficaram em situação intermediāria, não predominando nem genes recessivos e nem genes dominantes.

4.4.2.2. Caracteres relacionados à maturidade

Entre os caracteres relacionados à maturidade foram pesquisados NDM, NIM e APM (Figura 4).

O NDM (Figura $4 \mathrm{a}$ ) apresentou $\mathrm{b}=0,9476 \pm 0,0689$, o qual não diferiu significativamente da unidade. 0 valor de $\mathbf{A}=-0,4932 \mathrm{fez}$ com que a reta da regressão interceptasse o eixo das covariâncias muito próximo da origem, de modo que há indicação de dominância completa ou de uma pequena sobredominância. A reta tangente à parábola interceptou $\circ$ eixo 
das covariâncias no ponto $\mathbf{B}=33,0293$. o grau médio de domi nância para o caráter foi estimado em 2,01. O valor do coeficiente de determinação foi próximo da unidade $\left(\mathrm{R}^{2}=0,959\right)$ in dicando ótimo ajuste dos pontos à reta de regressão. A cor relação entre $Y_{i}$ e $\left(C_{i}+V_{i}\right)$ foi de $r=0,459$, não significati va. Na geração $F_{1}$, LEFFEL \& WEISS (1958) obtiveram grau mëdio de dominância 0,06 e KAW \& MENON (1983) estimaram em 0,85. Esses ūltimos autores obtiveram também o valor de 0,96 para o coeficiente de correlação entre $Y_{i}$ e $\left(C_{i}+\right.$ $v_{i}$ ), que é praticamente o dobro do valor obtido neste estudo, porém com o mesmo sinal, o que confirma que a ação dos genes dominantes e recessivos foram semelhantes nos dois estudos. Os genes dominantes contribuiram para reduzir, enquanto os recessivos contribuiram para aumentar a expressão do carāter. Os parentais distribiuram-se muito próximos uns dos outros no gráfico $C_{i} / V_{i}$ com exceção do cultivar paraná que colocou-se bastante distante dos demais (Figura 4a). Desse modo, a or-dem de dominância apresentou os cultivares Hale 321, Primave ra, Coker 136, Forrest, FT 81-1835, IAC-Foscarin-31, Década e Palmetto em um extremo, todos possivelmente com pequenas diferenças em termos do número de genes dominantes que possuem e no outro extremo o cultivar Paraná concentrando o maior número de genes recessivos.

No NIM (Figura 4b) a reta de regressão interceptou o eixo das covarjâncias acima da origem $(A=0,0212)$ e 
o coeficiente de regressão $(b=1,2362 \pm 0,2182)$ não diferiu significativamente da unidade. O coeficientede determinação $\mathrm{R}^{2}=0,842$ demonstra que os pontos ajustaram-se bem à reta de regressão. A reta tangente à parábola interceptou o eixo das covariâncias em $\mathbf{B}=0,0605$, o que resultou em um grau mé dio de dominância de 1,61. O coeficiente de correlação entre $Y_{i}$ e $\left(C_{i}+v_{i}\right)$ para NIM foi de 0,145 (não significativo). Em termos de valor absoluto è aproximadamente igual ao de NIF; entretanto, apresenta sinal contrário ao daquele coeficiente. Vale ressaltar, porém, que os dois coeficientes foram não significativos, desse modo, é provável que essa diferença de sinal não tenha nenhum significado genético.

Os cultivares apresentaram uma distribuição relativamente ampla ao longo da reta de regressão, o que sugere que os mesmos têm diferentes números de genes dominan tes no controle do NIM. Os parentais SOC 81-79 e Haie 321 foram os que apresentaram o maior número de genes dominantes; os cultivares coker 136 e IAC-Foscarin-31 colocaram-se no extremo oposto, ou seja, com o maior número de genes recessí vos; os demais parentais colocaram-se em uma posição intermediāria em número de genes recessivos e dominantes. Dos dez parentais que foram estudados quanto ao NIF, apenas oito foram avaliados quanto ao mesmo caráter na maturidade, tendo sido excluídos os parentais Primavera e Década. Dos parentais comuns aos dois estudos, Hale 321 apresentou o maior nú mero de genes dominantes para os dois caracteres. Os parentais 
Paranā, Forrest, FT 81-1835, Palmetto, tambēm apresenta ram posições relativas semelhantes, detendo um número intermediārio de genes dominantes. Já os parentais coker 136 e Soc 81-79 que apresentaram respectivamente predominância de ge nes dominantes e recessivos para o NIF, apresentaram justamente o oposto para o NIM. O comportamento desses parentais sugere que possivelmente sistemas gênicos diferentes controlam esses dois caracteres. Inclusive as correlações genēticas entre eles foram baixas, tanto nos parentais quanto nas progênies $F_{2}$ (Tabela 16).

A APM (Figura 4c), a exemplo do que ocorreu com APF, apresentou a reta de regressão interceptando o eixo das covariâncias acima da origem $(A=55,7021)$. Porềm, apre sentou o coeficiente de regressão $(b=1,0936 \pm 0,1889)$ bem superior aos da APE. Os pontos apresentaram um bom ajuste à reta de regressão com o coeficiente de determinação $R^{2}=0,848$. A reta tangente à parábola interceptou o eixo das covariâncias em $=243,6718$, o que proporcionou um grau mëaio de dominância de 1,76. Esse resultado reflete a ocorrência de sobreảominância na expressão do caräter, estando em acordo com os resultados obtidos por LEFFEI \& WEISS (1958) e KAW \& MENON (1983) para a geração $F_{I}$ - o coeficiente de corxelação entre $Y_{i}$ e $\left(C_{i}+V_{i}\right)$ foi de $r=0,507$ (não significativo) valor este pröximo do obtido por KAW \& MENON (1983) ( $r=0,62)$ e ambos com o mesmo sinal. Os parentais Primavera e soc 81-79 apresentaram o maior nümero de genes dominantes, o cuI 
tivar IAC-Foscarin-3l apresentou o maior nümero de genes recessivos e os demais parentais situaram-se intermediariamente.

$$
\text { Relacionando-se os resultados obtidos para }
$$
APF e APM, verifica-se que apenas seis dos dez parentais foram comuns no estudo desses dois caracteres. No caráter APF os parentais apresentaram distribuição relativamente mais concentrada do que no caráter APM. Isso sugere que, em termos de distribuição de genes dominantes, os parentais são mais semelhantes para APF do que para APM. Uma evidência clara disso são os cultivares IAC-Foscarin-31 e soc 81-79que estão bem próximos no gráfico da APF e nos extremos da reta no caráter APM. Esse resultado também evidencia que possivelmente sistemas gênicos diferentes controlam esses dois caracteres. Essa evidência é reforçada pelas bäixas estimativas obtidas para o coeficiente de correlação genotipica en tre eles, tanto nos parentais quanto nas progènies $F_{2}$.

\subsubsection{Acamamento e valor agronômico}

Como descrito em material e métodos, esses ca racteres foram quantificados subjetivamente através de ava-liação visuál de um só avaliador. Ambos não mostraram homogeneidade das diferenças $\left(C_{i}-V_{i}\right)$, sendo o teste "F" signífi cativo ao nível de probabilidade de 5\%. 
o caräter Ac (Figura 5a) apresentou o coeficiente de regeressão $b=0,6434 \pm 0,1302$, o qual diferiu de zero ao nível de probabilidade de 1\% e da unidade ao nível de 5\%. Esse carāter, portanto, da maneira que foi avaliado, apenas se aproximou do modelo aditivo-dominante. 0 coeficiente de regressão linear foi $A=0,0039$. A reta tangente à parábola interceptou o eixo das covariâncias em $B=0,0154$, obtebdo-se portanto um grau médio de dominância de 1,73 . o coeficiente de determinação foi $R^{2}=0,830$, evidenciando que os dados ajustaram-se satisfatoriamente à regressão linear. A correlação entre $Y_{i}$ e $\left(C_{i}+V_{i}\right)$ foi de 0,902019 , significati vo a 1\%. Esses resultados indicam que os genes dominantes reduzem e os recessivos aumentam o acamamento. Embora não atendendo satisfatoriamente ao modelo aditivo-dominante, o valor da correlação entre $Y_{i}$ e $\left(C_{i}+V_{i}\right)$ permitiu o cálcul do Iimite de seleção para esse carātex. o limite mínimo de seleção sendo de $1,295^{1}$ e o mäximo de 1,4120. Ë importante salientar que vários parentais apresentam acamamento médio inferior ao limite minimo calculado (Tabela 14); isso de cer to modo reflete a precisão apenas aproximada da análise grâ fica desse caráter. En termos de ordem... de dominância, o pa rental coker 136 e o que reune o maior nủmero àe genes dominantes, no outro extremo estão os parentais IAC- Foscarin-3I e Palmetto que reunem o maior nümero de genes recessivos. Os

1 Dados retransformados para a escala original. 
demais parentais situaram-se intermediariamente, porēm mais próximo do Coker 136.

No carāter VA (Figura 5b) a reta de regressão interceptou $O$ eixo das ordenadas abaixo da origem $(A=-0,0046)$, indicando a ocorrência de sobredominância. o coeficiente de regressão $(b=0,6899 \pm 0,2119)$ diferiu de zero a $1 \%$ e não diferiu da unidade. O coeficiente de determinação $\left(R^{2}=0,642\right)$ mostrou um ajuste apenas razoável dos dados à reta de regres são. A partir do gráfico o grau méāio de dominância foi de 2,61, valor que reflete a ação gênica de souredominância na expressão do carāter. O coeficiente de correlação ente $\mathrm{Y}_{i}$ e $\left(C_{i}+V_{i}\right)$ foi de $r=-0,194$ (não significativo). Embora não sendo significativo o sinal negativo de $r$ evidencia que os genes dominantes têm efeito positivo para O VA. Em termos ordem de dominância, o parental coker 136 foi o que apresentou o maior número de genes dominantes, no outro extremo está o parental FT 81-1835, com a maior concentração de genes recessivos.

Como já foi comentado, VA e Ac não se ajustaram satisfatoriamente ao modelo aditivo-dominante. Essa não adequação pode ser decorrente do fato de realmente esse mode lo não ser suficiente para explicar geneticamente esses caracteres. Tambérn pode ser devido aos mëtodos de avaliação dos caracteres, particularmente no que se refere a atribui ção de notas por um ünic avaliador, ou ainda, das duas coisas conjuntamente. provavelmente, a média de duas ou mais 
avaliações, feitas por avaliadores diferentes, poderia permi tir uma análise mais precisa do controle genētico desses ca-" racteres.

\subsubsection{Produtividade}

Para o caráter PPI (Figura 6a), a reta de regressão interceptou o eixo das covariâncias abaixo da origen $(A=-4,3244)$. O coefici ente de regressão $(r=0,6491 \pm 0,1994)$ diferiu de zero ao nível de probabilidade de 5\% e não diferiu da unidade. O coeficiente de determinação $\left(R^{2}=0,421\right)$ foi relativamente baixo, indicando um pobre ajuste dos pontos à reta de regressão. A reta tangente à parábola interceptou o eixo das covariâncias em $B=58,3051$ fornecendo um grau médio de dominância de 2,07. Este valor evidencia a ocorrência de sobredominância. O coeficiente de correlação entre $Y_{i}$ e $\left(C_{i}+V_{i}\right)$ foi de $r=0,336$ (não significativo) apesar disto, houve evidência de que os genes recessivos têm efeito positivo sobre a produtividade, KAW \& MENON tambëm constataram sobredominância. Entretanto, obtiveram correlação negativa entre $Y_{i}$ e $\left(C_{i}+V_{i}\right)$. Isso iridica que no estudo realizado por esses autores cs genes dominantes tiveram efeito positivo sobre a produtividare. os resultados contrastantes obtidos para produtividade, entre outros fatores, podem ser devidos às diferenças entre os materiais genē ticos usados nos dois estudos. A distribuição dos parentais 
ao longo da reta de regressão pode ser visualizada em termos de quatro conjuntos os quais têm número de genes dominantes aproximados. Com maior número de genes dominantes destacase o cultivar Hale 321; en seguida vem o conjunto que reúne os cultivares Primavera, SOC 81-79 e Coker 136; en terceiro lugar, Paranā, IAC-Foscarin-3l e Dëcada; por ültimo, os cultivares Palmetto e Forrest. Este último conjunto è o que contém o maior número de genes recessivos.

No carāter PP (Figura 6b) a exemplo do que ocorreu na PPI, a reta de regeressão interceptou o eixo das covariâncias abaixo da origem $\left(A=-4,72.10^{4}\right)$. O coeficiente de regressão $(b=0,5728 \pm 0,1874)$ diferiu de zero ao nĩvel de probabilidade de 5\% e não diferiu da unidade. 0 coeficiente de regressão $\left(R^{2}=0,539\right)$ foi um pouco superior ao obtido para PPI, mas mesmo assim, evidencia um ajuste apenas razoável dos pontos à reta de regressão. A reta tangente à parábola interceptou o eixo das covariâncias em $8=25,87.10^{4}$, fornecendo um grau médio de dominância de 2,17. O coeficien te de correlação $\left(r=0,618\right.$, não significativo) entre $x_{i}$ e $\left(C_{i}+V_{i}\right)$ ficou muito pröximo da significância a 5\%. Desse modo, estimou-se o limite teōrico de seleção, que neste caso, è apenas aproximado. Os limites máximo e mínimo obtidos foram respectivamente de 3024 e $2047 \mathrm{~kg} / \mathrm{ha}$. Vale salientar, com relação ao limite máximo, que dois parentais e dez progênies $\mathrm{F}_{2}$ apresentaram produtividades superiores a esse limi te. 
Os parentais Hale 321, FT 81-1835 e Primavera foram os que apresentaram o maior número de genes dominantes, - IAC-Foscarin-31 foi o que apresentou o maior número de genes recessivos. Os demais ocuparam posições intermediárias.

Relacionando-se as análises gráficas da PPI e PP, em termos de regressão de $C_{i}$ sobre $v_{i}$, verifica-se que os resultados foram bastante semelhantes. Os valores dos coe ficientes de regressão (b) foram aproximados, ambas apresen taram o coeficiente linear (A) negativo, indicando a ocorrên cia de sobreảominância e ambas apresentaram o coeficiente de correlação entre $Y_{i}$ e $\left(C_{i}+v_{i}\right)$ posittivos, evidenciando que os genes recessivos têm efeitos positivos sobre a produtividade. Esses resultados, com exceção do sinal da correlação entre $Y_{i}$ e $\left(C_{i}+V_{i}\right)$ estão em acordo com os obtidos por LEFFEL \& WEISS (1958) e KAW \& MENON (1983). O posicionamento relativo dos parentais nos dois gráficos, entretanto, apresentou algumas alterações. Os parentais Hale 321, Primavera, Coker 136 e Paraná, apresentaran posicionamento relativamente semelhantes. Os demais parentais, com exceção de F'I'81-1835 que foi excluído da análise de PPI, ocuparam posições relativamente diferentes nos dois gráficos. Um fato importante a ser observado é que três dos quatro parentais que mantiveram posições relativas semelhantes são de hábito de crescimento determinado, enquanto que quatro dos cinco que apresen taram posições relativas difexentes são de hābito de crescimento indeterminado. 
Uma possivel explicação para as alterações nas posições relativas dos cultivares é um maior poder de compensação dos cultivares de crescimento indeterminado em relação aos de crescimento determinado. Isso pode ter tido maior influência sobre a PPI do que sobre a PP. Na PPI a amostra foi de 12 plantas, enquanto que na PP foi de 50 plan tas. Neste caso, o ef eito de compensação apresentado por al gumas plantas sofre uma diluição maior e interfere menos no resultado final. Eimportante observar também que a PPI apresentou um coeficiente de variação superior lem torno de 4\%) ao da PP (Tabela 11).

\subsubsection{Anälise numērica}

Para a análise numérico-quantitativa foì usado em cada caráter o mesmo conjunto de cultivares utilizado nas respectivas análise gráficas. No cálculo dos componentes da variância quando houve homogeneidade dos resíduos na análise da variância foram usadas as fórmulas obtidas a par tir do trabalho de SINGH \& SINGH (1984bi, as quais utilizam o resíduo geral, não desdobrado. Quando houve heterogeneida de entre os resíduos foram usadas as fórmulas adaptadas de HAYMAN (1958). 


\subsubsection{Caracteres relacionados ao florescimento}

Os dados referentes às anālises dos caracteres NDF, NIF e APF são apresentados na Tabela 19. Para todos esses caracteres os resíduos foram homogêneos (Tabela 18). Desse modo, seus componentes e parâmetros genéticos foram es timados segundo SINGH \& SINGH (2984b).

No caráter NDF, os componentes da variância genética $\hat{\mathrm{D}}, \hat{\mathrm{F}}, \hat{\mathrm{H}}_{1}$ e $\hat{\mathrm{H}}_{2}$ foram significativos ao nível de pro babilidade de 1\%. O grau médio de dominância foi de 0,609, revelando a ocorrência de dominância parcial, ou em outras palavras, a predominância da variância genëtica aditiva. o valor de $\hat{\mathrm{F}}$ positivo e de $\hat{\mathrm{N}} \mathrm{D} / \hat{\mathrm{N}} \mathrm{R}$ maior qua a unidade indicam que há maior freqüência de genes dominantes controlando a ex pressão do carátèr. A relação $\hat{\mathrm{H}}_{2} / 4 \hat{\mathrm{H}}_{1}=0,21$ inåica que há uma disttibuição relativamente uniforme nos parentais, dos alelos com efeitos positivos e negativos. A expressão (u-v) $\mathrm{h} / \mathrm{d}=1,3470$, próxima da unidade, denota uma contribúição aproximadamente uniforme dos locos para o grau de dominância. $\hat{\mathrm{N}}$ aproximadamente igual à unidade indica que pelo menos um gene ou bloco de genes com dominância estão envolvidos na expressão do NDF.

Esses resultados mostram-se bastante concordantes com os obtidos para a geração $F_{1}$ por LEFFEL \& WEISS (1958), KAW \& MENON (1983) e TOLEDO \& KIIHL (1982b). TOLEDO 
\& KIIHL (1982a) concluiram pela existência de pelo menos três genes controlando NDF atravēs de efeitos aditivos e dominantes. No que se refere aos efeitos aditivos e dominantes, os resultados obtidos neste trabaiho estão em acordo com essa conclusão. Predominância da ação gênica aditiva no controle do carâter NDF também tem sido constatada por outros autores (BRIM \& COCKERHAM, 1961 e CROISSANT \& TORRIE, 1971). As herdabilidades obtidas no sentido restrito e amplo foram respectivamente de 0,708 e 0,940. Essas estimativas estão em acordo com as apresentadas por outros autores (ANAND \& TORRIE, 1963; CHAUHAN \& SINGH, 1984; DESTRO et ali.i, 1987: JOHNSON et alii, 1955b; KNOW \& TORRIE, 1974 e TOLEDO \& KIIHL, 1982b).

No carāter NIF, apenas os componentes $\hat{D}$ e $\hat{F}$ foram significativos ( $1 \%$ ). $\hat{H}_{l}$ foi positivo e maior que o er ro padrão, portante, a penas evidenciando a ocorrência de do-. minância. Contudo, $\hat{\mathrm{F}}$ significativo indica uma predominância de genes dominantes em relação aos recessivos, permitindo ad mitir que há efeito de dominância na expressão do NIF. $\overline{\mathrm{H}}_{2}$ foi negativo, mas, não significativo. Sendo $\hat{\mathrm{H}}_{1}>\hat{\mathrm{H}}_{2}$, eviden cia-se a assimetria entre os genes de efeito positivo e os de efeito negativo. Com base nesses resultados pode-se considerar que o NIF foi controlado predominantemente por ação gênica aditiva. Embora $\hat{H}_{1}$ não tenha sido significativo, outros parâmetros genéticos foram estimados. O grāu médio de dominância foi de 0,473 , confirmando a predominânciados efei 
tos aditivos. $\hat{N} D / \hat{N} R$ foi superior à unidade, reafirmando a maior freqüência de alelos dominantes em relação aos recessí vos e $(u-v) h / d$ foi menor que a unidade indicando que não hou ve uniformidade da participação dos locos na contribuição pa ra o grau médio de dominância. A herdabilidade no sentido restrito foi de 0,873 ; como $\hat{\mathrm{H}}_{2}$ foi considerado zero, a herda bilidade no sentido amplo assume o mesmo valor da herdabilidade no sentido restrito.

Para APF, apenas $\hat{D}$ foi significativo (1잉. $\hat{F}$ foi positivo e superior ao seu respectivo erro padrão, evidenciando que pode haver maior froqüência dos alelos dominan tes em relação aos recessivos. A estimativa de $\hat{\mathrm{H}}_{\mathfrak{l}}$, embora po sitiva, foi menor que seu erro padrão e a de $\mathrm{H} 2$ foi negativa. Esses resultados mostram que esse carāter foi controlaāo pre dominantemente pela ação gênica aditiva. Embora alguns componentes da variância tenham sido não significativos, foram realizadas estimativas de alguns parâmetros genéticos que em decorrência disso devem ser consideradas com uma certa reser va. O grau médio de dominância foi de 0,363 revelando dominância parcial. O valor $\hat{N} D / \hat{N} R$ fois:maior que a unidade, reve lando a predominância de genes dominantes, Os resultados mostram tambēm que a contribuição dos locos para o grau mēdio de dominância não foi uniforme $((u-v) h / d=0,4338)$. A exemplo do NIF, sendo negativa, a estimativa de $\hat{\mathrm{H}}_{2}$, as estimativas da herdabilidade no sentido amplo e restrito têm o mesmo valor 0,878 . 
KAW \& MENON (1983), obtiveram na geração $F_{1}$ ' valores significativos para $\hat{\mathrm{D}}, \hat{\mathrm{F}}, \hat{\mathrm{H}}_{1}, \hat{\mathrm{H}}_{2}$ e um grau médio de dominância de 0,60 . Esses resultados mostram a ocorrência de ações gênicas aditiva e de dominância controlando a expressão da APF; pode-se considerar que houve predominância da ação gênica aditiva. Também obtiveram $\hat{\mathrm{N}} \mathrm{D} / \hat{\mathrm{N}} \mathrm{R}>1$ e herdabilidade de 0,836, resultados que estão em acordo com os obtidos neste trabalho. Por outro lado, CAMACHO (1971) a partir de progênies $\mathrm{F}_{3}$ e $\mathrm{F}_{4}$ obtidas a partir de plantas $\mathrm{F}_{2}$, obtiveram valores significativos para as variâncias devido aos efeitos aditivos e de dominância; considerando que a variância de dominância foi bem superior à variância aditiva, pode-se admitir que os efeitos de dominância foram mais impor tantes para a expressão da APF. O reflexo do maior valor de variância de dominância foi mostrado na herdabilidade no sen tido restrito que foi apenas de 0,406. DESTRO et alii(1987) a partir de progênies $\mathrm{F}_{3}$ e $\mathrm{F}_{4}$ obtiveram estimativas de herda bilidade que variaram de 0,40 a 0,97 no sendito restrito e de 0,00 a 0,90 no sentido amplo. Desse modo, a estimativa de 0,878 obrido neste estudo está na faixa dos valores apresentados na literatura.

Nos três carácteres, NDF, NIF, APF', os resultados mostram que pela anälise numërica os efeitos gênicos aditivos foram mais importantes, o que inclusive resultou na constatação de dominância parcial nos mesmos. Esses resultados, porëm não estão de acordo com os obtidos na ' análise 
grāfica onde foi constatada sobredominância. Uma possível explicação para esses resultados é que pode ter ocorrido efeito complementar entre os genes, o qual desloca a reta de regressão da inclinação próxima da unidade ( DICKINSON \& JINKS 1956) e interfere na regressão $C_{i}$ sobre $V_{i}$, aumentando a relação $\hat{\mathrm{H}}_{1} / \hat{\mathrm{D}}$ (HAYMAN, 1954b), contribuindo para que o grau médio de dominância na análise gráfica seja superestimado.

4.4.3.2. Caracteres relacionados à maturidade

Os componentes de variância e os parâmetros genéticos estimados para NDM, NIM è APM são apresentados na Tabela 20. Os caracteres NDM e APM apresentaram residuos he terogêneos e, por isso, seus componentes de vaxiância e parâa metros genéticos foram estimados segundo HAYMAN (1958). Jä - NIM teve resíduos homogêneos e seus componentes da variân cia e parâmetros genéticos foram estimados segundo SINGH \& SINGH (1984b) (Tabela 9).

No NDM os componentes $\hat{D}, \hat{H}_{1}$ e $\hat{H}_{2}$ foram signi ficativos ( $(1 \%)$. $\hat{\mathrm{F}}$ foi negativo e praticamente igual ao seu erro padrão, sugerindo que pode haver uma leve predominância da freqüência dos genes recessivos cm reláão aos dominantes. O grau médio de dominância foi de 1,5l revelando a presença de sobredominância e, tambēm, que a ação gênica dominante foi mais importante que a aditiva. A relação $\tilde{N} D / \hat{N} R=0,805$, indica que hâ maior freqüência de genes recessivos do que do 
minantes envolvidos no controle do caráter. Entretanto,como $\hat{F}$ não foi significativo esse resultado è apenas aproximado. A princípio, este resultado mostra-se en desacordo com a ocorrência de sobredominância. Uma possivel explicação para o mesmo é que pode haver maior número de genes recessivos de pequenos efeitos o que causa $\hat{\mathrm{N}} \mathrm{D} / \hat{\mathrm{N}} \mathrm{R}<\mathrm{l}$ e um menor número de genes dominantes com grandes efeitos, de modo a causar um grau médio de dominância maior que a unidade. A expressão $\hat{\mathrm{H}}_{1} / 4 \hat{\mathrm{H}}_{2}<0,25$ indica que hā assimetria entre as freqüências dos alelos com efeitos positivos e negativos. 0 valor de $(u-v) h / d<1$, negativo e relativamente próximo de zero indica que há uma variação indepenảenté de $h$ e d nos difierentes locos. Entretanto, essa estimativa $\bar{e}$, aproximada, uma vez que ela depende de $\hat{\mathrm{F}}$ e este não foi significativo. $\hat{\mathrm{N}}$ que estima o número de fatores efetivos teve um valor de 6,0, indicando que pelo menos seis locos ou blocos gênicos corn dominância interferem com o caráter NDM. O gráu médio de dominância ob tido nessa análise numérica está de acordo com o obtido na análise gráfica que tambēm revelou sobredominância.

Para a geração $F_{1}$, LEFFEL \& WEISS (1958) e KAW \& MENON (1983) obtiveram dominância parcial, ou seja, predominância da ação gênica aditiva, o oposto do obtido neste estudo: Outros autores, usando metodologias e geraçōes dife rentes também têm encontrado predominância da ação gênica aditiva no controle do número de dias para maturação (BRIM \& COCKERHAM, 1961; CECON et alii, 1985; CROISSANT \& TORRIE, 
1971; HANSON \& WEBER, 1961, 1962; HANSON et alii, 1967; LEFFEL \& HANSON, 1961). Provavelmente, a predominância da ação gènica dominante constatada neste estudo deva-se ao fato do mesmo reunir um conjunto de parentais precoces, que sem dúvida concentram genes para esse caráter. Tambēm por serem precoces já tiveram sua variabilidade genética aditiva reduzida através do processo de seleção para precocidade.

As herdabilidades estimadas neste trabalho fo ram de 0,669 e 0,898 no sentido restrito e amplo, respectiva mente. Para a geração $\mathrm{F}_{1}$, KAW \& MENON (1983) obtiveram o valor de 0,719 para herdabilidade no sentido restrito. Essas estimativas, particularmente, a obtida no sentido amplo está na faixa das que têm sido obtidas para diferentes gerações por outros autores (ANAND \& TORRIE, 1963; CHAUHAN \& SINGH, 1984; HANSON \& WEBER, 1962; JOHNSON et alii, 1955a; KNOW \& TORRIE, 1964 e MAHMUD \& KRAMER, 1951).

O caráter NIM apresentou $\hat{\mathrm{D}}, \hat{\mathrm{F}}, \hat{\mathrm{H}}_{1}$ e $\hat{\mathrm{H}}_{2}$ significativos (1\%). O grau médio de dominância foi de 0,74, revelando dominância parcial, ou seja, predorninância da ação gênica aditiva no controle do carāter. A relação $\hat{N} D / \hat{N} R>1$ indica maior freqüència de genes dominantes nos parentais. Foi constatada uma distribuição desuniforme dos alelos com efeitos positivos e negativos nos parentais $\left(\hat{\mathrm{H}}_{1} / 4 \hat{\mathrm{H}}_{2}<0,25\right)$. o valor $(u-v) h / d=0,9174$ (próximo da unidade) indica que houve uma constância da relação h/d e uma contribuição relativamente uniforme dos locos para o grau médio de dominân- 
cia. O número de fatores efetivos com dominância $(\mathrm{N}=0,74)$ indica que pelo menos um loco ou bloco gênico com dominância está envolvido no controle do NIM. A herdabilidade no sentido restrito foi de 0,641 e no amplo de 0,948.

Os resultados neste estudo são bastante concordantes com os obtidos por KAW \& MENON (1983) com a geração $F_{1}$ para o número de nós. Esses autores obtiveram dominância parcial com o grau de dominância de 0,75 e herdabilidade no sentido restrito de 0,77. Estimativas de herdabilidade no sentido amplo foram tambēm apresentadas por JOHNSON et alii (1955a) para duas populações de progênies $F_{5}$, respectivamente 0,69 e 0,63. De um modo geral, os resultados deste trabalho não diferem dos encontrados na literatura.

No carāter APM, a exemplo do que foi observado para NIM, os componentes $\hat{\mathrm{D}}, \hat{\mathrm{F}}, \hat{\mathrm{H}}_{1}$ e $\hat{\mathrm{H}}_{2}$ foram significati vos (1\%). O grau médio de dominância foi de 1,08, muito pró ximo da unidade. Isso sugere a presença de dominância completa ou de leve tendência de sobredominância. $\hat{N} D / \hat{N} R>1$ indica maior froqüência de genes dominantes nos parentais. A relação $\hat{\mathrm{H}}_{1} / 4 \hat{\mathrm{H}}_{2}<0,25$ mostra que a exemplo dos outros dois ca racteres relacionados à maturidade, O APM também não apresentou distribuição uniforme dos genes com efeito positivo e ne gativo. A expressão $(u-v) h / d=0,925$ (pröxima da unidade) mostra que houve constância da contribuição dos locos para o grau médio de dominância. O valor do número de fatores efe- 
tivos $(N=0,646)$ sugere que pelo menos um loco ou bloco gênico com dominância está envolvido na expressão NIM. As her dabilidades no sentido restrito e amplo foram respectivamente de 0,335 e 0,923 .

LEFFEL \& HANSON (1961), com progênies $F_{2}$, obtiveram resultádos que indicaram uma predominância da ação gênica dominante, com estimativas do grau médio de dominância de 1,17; 1,21 e 2,01. Por outro lado, BHATADE et alii (1977) com progênies $F_{2}$, obtiveram predominância da ação gênica aditiva com grau médio de dominância de apenas 0,30. Es ses autores, obtiveram herdabilidadè de 0,45, que está relativamente próxima da obtida neste estudo em sentido restrito $\left(h_{r}^{2}=0,335\right)$. Em termos de componentes da variância, LEFFEL \& WEISS (1958) e KAW \& MENON (1983) obtiveram em Fl resultados que estão em acordo com os obtidos neste estudo. Entretanto, estimaram grau mëdio de dominância em torno de 0,70, o que indica a ocorrência da dominância parcial, ou seja, uma predominância da ação gênica aditiva no controle do. APM. KAW \& MENON (1983) também obtiveram herdabilidade no sentido res trito de 0,76 , mais que o dobro da obtida neste estudo. Atra vés de outras metodologias, outros autores têm constatado ação gênica aditiva, no controle da expressão do APM (BRIM \& COCKERHAM, 1961; CECON et alii, 1985; CROISSANT \& TORRIE, 1971; HANSON \& WEBER, 196I, 1962; HANSON et alii, 1967). A herdabilidade no sentido amplo para APM tem sido estimada por diferentes mētodos por värios autores. ANAND \& TORRIE 
(1963) obtiveram valores que variaram de 0,55 a 0,94 ; CHAUHAN \& SINGH (1984) de 0,34 a 0,80; KNOW \& TORRIE (1964) de 0,67 a 0,70; JOHNSON et alii (1955a) de 0,61 a 0,81) e MAHMUD \& KRAMER (1951) de 0,35 a 0,91. Os resultados obtidos neste estudo, para APM, portanto, estão relativamente em acordo com a literatura.

\subsubsection{Acamamento e valor agronômico}

As estimativas dos componentes da variância e dos parâmetros genéticos para o Ac e O VA são apresentados na Tabela 21. Esses dois caracteres apresentaram residuos heterogêneos (Tabela 10), desse modo, seus componentes de variância e parâmetros genéticos foran estimacos segundo HAYMAN (1958).

No caráter AC, dentre os componentes genéticos da variância, apenas $\hat{D}$ foi positivo, sendo tambēm significativo ( $(1 \circ)$. $\hat{\mathrm{F}}, \hat{\mathrm{H}}_{1}$ e $\hat{\mathrm{H}}_{2}$ foram negativos. Desse modo, não foi possível estimar outros parâmetros genéticos. Admitindo que estes parâmetros são nulos, evidencia-se que esse carāter foi controlado por ação gênica aditiva. LEFFEL \& HANSON (1961) com "bulk" $F_{2}$ obtiveram dominância parcial, mas com um "bulk" $\mathrm{F}_{3}$ obtiveram sobredominânci.a. Nesta análise não foi possível estimar a herdabilidade para Ac, entretanto alguns autores têm apresentado estimativas de herdabilidade no sentido amplo para esse carāter. ANAND \& TORRIE (1963) obti veram estimativas que variaram de 0,35 a 0,61 ; BYTH et alii (1969) de 0,64 a 0,72; FEHR \& WEBER (1968) de 0,60 e 0,75; 
KNOW \& TORRIE (1964) de 0,51 e 0,74; JOHNSON et alii (1955a) de 0,34 e 0,73; e SMITH \& WEBER (1968) de 0,49 e 0,81. DESTRO et alii (1987), nas gerações $\mathrm{F}_{3}$ e $\mathrm{F}_{4}$, obtiveram respectivamente, estimativas que variaram de 0,00 a 0,94 e de 0,71 a 0,84 . Outros resultados apresentados na literatura apontam a ação gênica aditiva como o componente mais importante na expressão do AC (BRIM \& COCKERHAM, 1961; CROISSANT \& TORRIE, 1971; HANSON \& WEBER, 1961, 1962 e HANSON et alii, 1967), o que está de acordo com os resultados obtidos neste estudo.

As estimativas dos componentes genéticos da variância no caráter VA foram todos significativos; com exce ção de $\hat{F}$ que foi significativo a 5\%, os demais componentes foram significativos a 1\%. O grau médio de dominância foi de 2,73, indicando marcante presença de sobredominância na expressão do VA. A relação $\hat{\mathrm{N}} \mathrm{D} / \hat{\mathrm{N}} \mathrm{R}>1$ indica que nos parentais há uma maior freqüencia de genes dominantes. o valor de ${ }^{* \hat{H}_{\dot{Z}}} / 4 \hat{H}_{1}<0,25$ sugere distribuição desuniforme dos alelos com efeitos positivos e negativos nos parentais. O resultado obtido para $(u-v) h / d=0,556$ indica que não houve contribuição uniforme dos locos para o grau médio de dominância. O número de fatores efetivos estimado $(\mathbb{N}=0,669)$ sugere que pelo menos um gene ou kloco gênico com dominância está envol vido no controle do VA. As estimativas da herdabilidade no sentido restrito e amplo foram respectivamente de 0,289 e 0,804 . 
Neste estudo, O VA foi controlado por ação gê nica aditiva e dominante, porém, a dominante foi muito superior à aditiva; em decorrência disso, O VA apresentou baixa herdabilidade no sentido restrito. Dessa maneira, o VA se mostra de pouco valor para seleção em $F_{2}$ e possivelmente, pa ra casos em que se deseja exercer forte pressão de seleção.

\subsubsection{Produtividade}

Os componentes devariância estimados para PPI e PP são apresentados na Tabela 22. Esses dois caracteres apresentaram resíduos homogèneos (Tabela 11) e assim, seus componentes de variância $€$ parâmetros genēticos foram estima dos segundo SINGH \& SINGH (1984b).

No carāter PPI, apenas os componentes genēti$\cos \hat{\mathrm{D}}$ e $\hat{\mathrm{H}}_{2}$ foram significativos (I\%). $\hat{\mathrm{F}}$ foi negativo e infe rior ao erro padrão, desso modo, sua estimativa pode ser con siderada zero. $\hat{H}_{1}$ embora não sendo significativo, foi quase o dobro do erro padrão, evidenciando a ocorrência de ação gệ nica dominante na expressão do carāter. O grau médio de dominância foi de 0,768, indicando a ocorrência de dominância parcial. Entretanto, esse valor, não pode ser encarado como uma estimativa precisa, pois $H_{l}$ não Eoi significativo. Quan to à estimativa de $\mathrm{H}_{1}$, pelo menos duas hipóteses podem ser levantadas; a) os efeitos da dominância expressos através de $\mathrm{H}_{l}$ são realmente de pequena magnitude e não significativos 
no nível de precisão usado nessa análise; e b) $H_{1}$ foi subestimado. Essa segunda hipótese é talvez a mais provável, uma vez que outros autores (LEFFEL \& WEISS, 1958 e KAW \& MENON, 1983; em $F_{1}$ e BHATADE et alii, 1977 e LEFFEL \& HANSON, 1961; em $\mathrm{F}_{2}$ ) têm constatado dominância para PPI. A relação $\mathrm{H}_{2} / 4 \mathrm{H}_{1}=$ 0,51 , confirma a pouca precisão da estimativa de $\mathrm{H}_{1}$, uma vez que essa expressão reflete o valor do produto da freqüência gênica média dos locos onde occrre dominância uv, o qual tem um limite teórico máximo de 0,25. O número de fatores efetí vos estimado $(\hat{\mathrm{N}}=1,31)$, sugere que pelo menos um loco ou um bloco gênico com dominância está relacionado ao controle da PPI e de certo modo confirma a dominância parcial constatada. As herdabilidades estimadas no sentido restrito e amplo foram respectivamente de 0,318 e 0,811 .

Para PP, todos os componentes genéticos da va riância $\left(\hat{\mathrm{D}}, \hat{\mathrm{F}}, \hat{\mathrm{H}}_{1}\right.$ e $\hat{\mathrm{H}}_{2}$ ) foram significativos a 1 . de 2,33 para o grau médio de dominância indica a presença de sobredominância e está em acordo com os dados da literatura, tanto para $\mathrm{F}_{1}$ (KAW \& MENON, 1983; LEFFEL \& WEISS, 1958) como para $\mathrm{F}_{2}$ (BHATADE et alii, 1977 e LEFFEI \& HANSON, 1961). Re ferindo-se à geração $F_{I}$, KAW \& MENON (1983) mencionaram com ba se em relatos de outros autores que a dominância e a epistasia são completamente confundidas e que a sobredominância constatada para produtividade é duvidosa, podendo ser mais conseqüência de desiquilïbrio de ligação ou interações não alélicas do que sobredominância propriamente dita. 
A estimativa positiva de $\hat{F}$, indica maior freqüência de genes dominantes do que recessivos nos parentais. A relação $\mathrm{H}_{2} / 4 \mathrm{H}_{1}=0,20$ (próximo de 0,25 ) indica que os alelos com efeitos positivos e os alelos com efeitos negativos têm distribuição relativamente uniforme nos parentais. A es timativa da constância entre efeitos de dominância e efeitos aditivos $(u-v) h / d=0,83$, próximo da unidade, sugere uma constância de razão h/d e uma contribuição uniforme dos locos com dominância para o grau médio de dominância da PP. o número de fatores efetivos que reflete o número de locos ou blocos gêneicos com dominância envolvidos na expressão de carāter $(\hat{\mathrm{N}}=0,0 Q)$ sem dūvida está subestimado. Isso ocorre quando os efeitos de dominância dos genes não são iguais em magnitude e direção e/ou quando hā uma distribuição correlacionada de alelos nos parentais. Na realidade nenhuma dessas duas hipōteses pode ser completamente descartada. A pri meira porque é pouco provăvel que todos os genes tenham efei tos de dominância iguais em magnitude e direção. A segunda porque, embora esses parentais sejam relativamente divergentes, eles já sofreram seleção para produtividade e aqueles que por ventura tenham um ancestral comum, embora distante, devem ter material genético mais semelhante entre si do que com os outros.

As estimativas de herdabilidade em sentido restrito e amplo foram respectivamente de 0,132 e 0,953. Es- 
sas estimativas refletem a marcante presença da ação gênica dominante na expressão do carāter.

As estimativas de herdabilidade para produtivi dade encontrados na literatura apresentam ampla variação. No sentido restrito, ANAND \& TORRIE (1963) obtiveram estimativas que variaram de 0,12 a 0,27; BHATADE et alii (1977) de 0,52; DESTRO et alii (1987) de 0,00 a 0,08; KAW \& MENON (1983) de 0,29; MAHMUD \& KRAMER (1951) de 0,06 a 0,77. No sentido amplo, ANAND \& TORRIE (1963) obtiveram estimativas que varia ram de 0,23 a 0,50; DESTRO et alii (1987) de 0,00 a 0,90; CHAUHAN \& SINGH (1981) de 0,50 a 0,90; HANSON \& WEBER (1962) de 0,40 a 0,53 ; JOHNSON et alii (1955a) de 0,25 a 0,40; KNOW \& TORRIE (1964) de 0,03 a 0,10; MAHMUD \& KRAMER (1951) de $0,43,0,67$ e 0,76; RONNIS et alii (3985) de 0,52 a 0,59. Cons tata-se, portanto, que as estimativas obtidas neste estudo estão na faixa de variação dos resultados encontrados na literatura.

Relacionando-se as anālises da PPI e PP (Tabe la 22), constata-se que a avaliação da PP possibilitou meIhor ajuste ao método e tanto os componentes da variância quanto os parâmetros genéticos apresentaram valores mais coerentes. Possivelmente, isso se deva ao maior nümero de plantas amostradas, neste caso todas as plantas da parcela.

Este estudo, como outros realizados com a gera ção $F_{1}$ ou $F_{2}$ mostra que nestes níveis de homozigose os efei 
tos gênicos de dominância sobrepujam os efeitos gênicos aditivos para o carāter produtividade. Entretanto, em níveis mais altos de homozigose, os resultados da literatura divergem dos resultados obtidos. BRIM \& COCKERHAM (1961) CROISSANT \& TORRIE (1971) afinmaram que os efeitos aditivos são os mais importantes. HANSON \& WEBER (1961, 1962) a partir de dados que apresentam erros padrões relativamente altos relataram que a ação gênica epistática pode ser uma fonte de variabilidade para a produtividade. Entretanto, HANSON et alii (1967) afimaram que a ação gênica epistātica é uma impor tante fonte de variabilidade para produtividade e apresentaram uma relação en torno de 0,7 entre a variância devida aos efeitos epistáticos aditivo $x$ aditivo, baseada em efeitos de locos homozigóticos, e a variância genētica total. Isso significa que em níveis elevados de homozigose a variância epís tática aditiva $x$ aditiva responde por aproximadamente $70 \%$ da variância genética para produtividade.

Diante desses resultados e das informações disponiveis na literatura seria importante que mais estudos genéticos em soja fossem desenvolvidos usando materiais homo zigóticos, que è o estado no qual a cultura é explorada, e me todologias que permitissem avaliar com precisão a importância dos efeitos epistāticos. 


\subsection{ANALISE DIALÉLICA DE GRIFFING}

Apōs realizada a análise de variância onde constatou-se diferenças significativas (1\%) para grupos de genótipos e para os desdobramentos da análise em ef eitos de parentais e de progênies $F_{2}$ para todos os caracteres estudados (Tabelas 8 a 1I), procedeu-se à análise da capacidade de combinação. Nesta análise, como os tratamentos do dialelo foram compostos dos parentais e dos cruzamentos sem recíprocos, utilizou-se o mëtodo 2, e em decorrência da escolha deliberada dos parentais foi usado o modelo misto B, no qual os efeitos de tratamento são fixos (GRIFFING, 1956b).

Os resultados das análises para a capacidade de combinação são apresentados na Tabela 23. A capacidade geral de combinação (CGC) e a capacidade específica de combí nação (CEC) foram significativas (1\%) para os caracteres NDF, NIM, APM, PPI e PP. Como a CGC decorre principalmente da variância genética aditiva e da variância epistática aditiva $\mathrm{x}$ aditiva e a CEC resulta da variância genética dominante e de vários tipos de componentes da variância epistática (GRIFFING, 1956a e KEMPTHORNE \& CURNOW, 1961) pode-se concluir que para a expressão desses caracteres as ações gènicas aditiva, dominante e possivelmente interações epistáticas foram importantes. Para os caracteres NIF, APF, NDM, AC e VA, apenas a CGC foi significativa (1\%). Portanto, podese admitir que esses caracteres foram controlados predominan 
temente por ação gênica aditiva e possivelmente epistática aditiva x aditiva. A importância relativa da CGC e da CEC foi avaliada para o modelo com efeito de tratamentos fixos segundo BAKER (1978). Para sete dos dez caracteres pesquísa dos a relação CGC/(CGC + CEC) foi superior a 90\%; para os outros três caracteres a relação foi superior a $70 \%$. Predominância da CGC en relação à CEC para produtividade componentes da produtividade e alguns outros caracteres tên sido obtidos para a geração $F_{1}$ por vários autores (KAW \& MENON, 1980, 1981; PASCHAL II \& WILCOX, 1975; SRIVASTAVA et alii, 1978a,b e WEBER et alii, 1970). Para a produtividade a participação da CGC variou de 53,2\% (SRIVASTAVA et alii, 1978a) a 91,2\% (PASCHAL II \& WILCOX, 1975). Essa predominância da CGC tambëm tem sido constatada en $F_{2}$ : BHATADE et alii (1977) obteve $78,4 \%$ para CGC e $21,6 \%$ para a CEC; SRIVASTAVA et alii (1978b) estimaram 60,8\% para CGC e 39,2\% para CEC.

CRUZ (1983) e MIRANDA (1987) relatam que quan do o conjunto de parentais é heterogêneo essa superioridade da CGC é esperada. Neste estudo os parentais são todos precoces e embora tendo sido escolhidos, em termos de genealogia, - mais distante possivel, não podem ser considerados altamente heterogêneos. Desse modo, pelos resultados deste estú do e pelos constatados na literatura foi evidenciada uma tendência da CGC ser superior à CEC, para produtividade e componentes da produtividade em soja. 
E importante ressaltar que este estudo foi realizado em um ano e em um único local; dessa maneira, as estimativas da CGC e CEC podem estar superestimadas em conseqüência do não isolamento das interações com esses fatores. Interações significativas, particularmente com anos, foram constatadas por KUNTA et alii (1985) e por PASCHAL II \& WILCOX (1975). Entretanto, estes últimos autores relataram que embora essas interações da CGC e CEC com anos tenham sido significativas elas foram de pequena magnitude, particularmente em relação à CGC. Desse modo, consideraram que a contribuição correspondente à superestimação pode ser despre zada. Caso isso possa ser generalizado para a soja, os dados obtidos em um ano e um local ídesde que não seja um ano atípico e nem um local especial) podem ser considerados satisfatórios para a avaliação da CGC e CEC de parentais e crú zamentos.

A estimativa da média da variância do efei to da CGC foi maior que a da CEC para sete dos dez caracteres pesquisados. Os outros três caracteres no caso VA, PPI e PP apresentaram estimativa da média da variância do efeito da . CEC maior do que a da CGC. Uma possível explicação para esses resul tados é que os parentais são cultivares melhorados ou linhagens experimentais jā submetidas a um processo. de seleção mais intenso, direta ou indiretamente, para estes três carac teres. Como se trata de uma espécie autógama, essa seleção 
deve ter atuado principalmente sobre a variabilidade genética devido aos efeitos aditivos, desse modo, reduzindo-a em relação à variabilidade devido aos efeitos de dominância.

Contudo, vale observar que a CGC para todos os caracteres foi maior que a CEC e por conseguinte a ação gênica aditiva e possivelmente epistática aditiva $\mathbf{x}$ aditiva foram mais importantes na expressão dos mesmos.

4.5.1. Capacidade geral de combinação

Os efeitos da cápacidade geral de combinação $\left(g_{i}\right)$, os erros padrões de $g_{i}$ e de $\left(g_{i}-g_{j}\right)$, o coeficiente de correlação ( $r$ ) entre $g_{i}$ e as respectivas médias dos parentais são apresentados na Tabela 24, para todos os parentais e caracteres estudados.

Desde que $\Sigma g_{i}=0$, quando a estimativa de $g_{i}$ do parental i tem baixo valor absoluto a CGC do parental i está em torno da média da CGC de todos os parentais. Por ou tro lado, estimativas de $g_{i}$ de alto valor absoluto indicam que o parental $i$ tem CGC superior $\left(g_{i}\right.$ positivo) ou inferior ( $g_{i}$ negativo) aos parentais com os quais está sendo comparado.

No caráter NDF, os valores de $g_{i}$ variaram de $-1,705$ a 3,453. Seis parentais apresentaram $g_{i}$ negativos, so bressaindo-se os parentais IAC-Foscarin-3l, FT 81-1835, Déca 
da e Forrest, respectivamente com valores de $g_{i}$ de $-1,705$; $-1,676 ;-1,491$; e $-1,142$ dias. Portanto, contribuindo genetisamente para reduções superiores a um dia para o início do florescimento. No outro extremo está o parental Palmetto com $g_{i}$ de 3,450 dias, o que representa uma contribuição média para atrasar em três ou quatro dias o início do floresci mento.

Para NIF, apenas quatro parentais apresentaram valores de $g_{i}$ positivos, Palmetto, Primavera, Coker 136 e Paranā, respectivamente 0,$188 ; 0,074 ; 0,057$ e 0,024 (dados transformados para $\sqrt{x+1}$ ). Desse modo, esses parentais têm potencial para contribuir para aumentar o NIF. Vale ressaltar que esses mesmos quatro parentais foram os que apresenta ram $g_{i}$ positivo para NDF.

Praticamente os mesmos parentais que apresertaram $g_{i}$ positivos para NIF, apresentaram também $g_{i}$ positivos para APF; exceção ocorreu no parental Hale 321 , que teve $g_{i}$ positivo para este caráter. As estimativas de $g_{i}$ variaram de-0,660 a $8,351 \mathrm{~cm}$, valor este apresentado pelo parental Palmetto, o qual mostrou o maior potencial para aumentar a $\mathrm{APF}$.

No caráter NDM, seis parentais apresentaram estimativas de $g_{i}$ negativas. Nesse caráter, os parentais apresentaram $g_{\dot{1}}$ variando de $-5,290$ a 5,499 dias. Os dois pa rentais que mais se sobressairam foram Hale 321 e FT 81-1835, 
com estimativas de $g_{i}$ respectivamente de $-5,285$ e $-3,029$ dias; esses resultados indicam que tais parentais têm poten cial para reduzir o NDM em cinco e três dias, respectivamente. Os outros quatro parentais apresentaram estimativas de $g_{i}$ negativas relativamente pequenas. Entretanto, consideran do a possibilidade de se intercruzar as plantas das gerações $F_{1}$ ou $F_{2}$ desses parentais, a contribuição deles poderá ser tambèrn importante para o aumento da precocidade na. maturidade.

Seis parentais apresentaram $g_{i}$ positivos para o NIM. As estimativas de $g_{i}$ variaram de $-0,280$ no parental Hale 321 a 0,253 no parental primavera (dados transformados para $\sqrt{x+1}$ ). Os parentais IAC-Foscarin-3l e Palemtto támbēm apresentaram valores de $g_{i}$ relativamente altos, respecti vamente 0,219 e 0,233. E importante observar que os parentais que apresentaram estimativas de $g_{i}$ negativas para NIM são de crescimento determinado e os que apresentaram $g_{i}$ posi tivas são de crescimento indeterminado.

Os mesmos parentais que apresentaram estimatí vas de $g_{i}$ positivas no NIM também o fizeram para a APM. IACFoscarin-3l e Palmetto apresentaram os maiores valores de $g_{i}$, respectivamente 14,03 e $15,92 \mathrm{~cm}$. Os parentais Primavera, SOC 81-79 e FT 81-1835 apresentaram valores de $g_{i}$ intermediārios, respectivamente 6,$869 ; 6,304$ e 5,229 cm. O paren tal FT 81-1835 teve um comportamento interessante, pois apre sentou o segundo melhor $g_{i}(-3,029$ dias $)$ para maturidade pre- 
coce e um $g_{i}$ de $5,229 \mathrm{~cm}$ para a APM. Nesse parental, em ter mos de CGC, esses dois caracteres tiveram um comportamento re lativamente independente. - Isso ... significa que ao mesmo tempo em que ele contribuiu para aumentar a precocidade, contribuiu também para aumentar a APM. Esse tipo de comportamento não foi observado nessa magnitude em nenhum outro pa rental. Vale observar também que apenas os parentais de crescimento indeterminado apresentaram $g_{i}$ positivos para APM e NIM. Neste grupo de parentais, parece que o potencial para aumentar esses caracteres, está relacionado ao hábito de crescimento indeterminado. Essa constatação è importante porque os caracteres relacionados à maturidade foram correlacionados positivamente entre si e com a produtividade.

No caráter $A C$, sete parentais apresentaram es timativas de $g_{i}$ negativas, portanto têm potencial para reduzir o Ac. Entre esses parentais sobressaîram-se Paraná, Coker 136 e Década, respectivamente com estimativas de $g_{i}$ de $-0,0499 ;-0,046$ e $-0,034$ (dados transformados para $\sqrt{x+1}$ ), os quais em valor absoluto, foram em torno de três vezes maiores que o erro padrão. Com exceção de primavera e FT 81-1835, os demais parentais que apresentaram $g_{1}$ positivos para Ac tambëm apresentaram as maiores contibuições para o aumento da APM.

Para VA, que è um caräter bastante complexo, pois envolve uma avaliação visual simultânea de vários carac 
teres, quatro parentais apresentaram estimativas de $g_{i}$ positivas. Desses, apenas Primavera e soC 81-79 com valores de $g_{i}$ de 0,049 e de 0,034 (dados tranformados para $\sqrt{x+1}$ ) fo ram maiores que o dobro do erro padrão.

Dos quatro parentais que apresentaram estimativas de $g_{i}$ positivas para VA, três também o fizeram para a PPI. Apenas dois parentais mudaram o sinal de $g_{i}$ de uma ava liação para outra. Isso pode ser interpretado como uma tendência do valor agronômico de refletir principalmente os com ponentes da produtividade, particularmente o nümero de vagens por planta que mais se sobressai em uma avlaição visual de planta individual. Este tipo de associação de certo modo é vantajosa, pois a produtividade é geralmente o objeti vo final da avaliação.

Para PPI, os parentais IAC-Foscarin-3I e SOC 81-79 foram os que apresentaram as maiores estimativas para $g_{i}$, respectivamente de 8,933 e $5,967 \mathrm{~g} /$ planta, tendo portanto potencial genético para contribuir com um aumento em torno de 5 a $8 \mathrm{~g}$ na PPI. Outros dois parentais que apresentaram $g_{i}$ positivos foram Primavera e Palmetto, respectivamen te 1,367 e 1,600 g/planta, valores que pouco diferiram do desvio padrão de $g_{i}$. Novamente se observa que somente paren tais de hábito de crescimento indeterminado apresentaram potencial para aumentar a expressão de um caráter, no caso, a PPI. 
Na PP, onde foram incluídos os pesos de grãos de todas as plantas da parcela, seis parentais apresentaram estimativas de $g_{i}$ positivas, entre os quais se destacaram IACFoscarin-31, Palmetto e Primavera com estimativas de $g_{i}$ resprectivamente de $398 ; 284$ e $104 \mathrm{~kg} / \mathrm{ha}$. Os outros très paren tais que apresentaram $g_{i}$ positivos foram Década, soc 81-79 e Coker 136, respectivamente 43; 21 e $9 \mathrm{~kg} / \mathrm{ha}$. Estes são todos menores que o erro padrão de $g_{i}$ que foi $46 \mathrm{~kg} / \mathrm{ha}$. A par tir desses dados, considerando que a avaliação que envolve todas as plantas da parcela (PP) deve fornecer melhores estimativas do que amostras de plantas dentro da parce la (PPI), os parentais que apresentaram maior potencial para contribuir geneticamente para o aumento da produtividade são IACFoscarin-31, Palmetto e Primavera.

A partir de uma visualização do comportamento dos pa rentais com base nos efeitos da CGC (Tabela 24), constata-se que para todos os caracteres esse grupo de parentais mostrou uma ampla variação de $g_{i}$. Nenhum dos parentais porém apresentou $g_{i}$ satisfatório para todos os caracteres. Como exemplo, o parental IAC-Foscarin-3l que apresentou o melhor comportamento em termos de PPI e PP, tendo sido satisfatōrio em outros caracteres, foi relativamente deficiente para acamamento e precocidade para maturidade. Por outro lado, o parental FT81-1835 que apresentou o menor efeito da CGC para PP, teve um bom comportamento em outros caracteres, entre eles a precocidade 
para maturidade, onde apresentou o segundo melhor $g_{i}$, com uma contribuição para redução do ciclo em torno de três dias. Desse modo, se evidencia que esse grupo de parentais apresen ta características complementares e em decorrència dessa variabilidade existente entre eles, têm potencial para formar, atravēs de intercruzamentos sucessivos uma população de ampla base genética.

Na Tabela 24, verifica-se tambëm que as corre lações entre os efeitos da CGC e as respectivas médias dos parentais, para todos os caracteres, foram altas e significa tivas a 1\%. KAW \& MENON (1980, 1981) obtiveram resultados semelhantes para a produtividade, componentes da produtivida de e outros caracteres. Esses resultados sugerem que, pelo menos a nível preliminar pode-se selecionar para CGC com base no comportamento do cultivar "per sẹ". Em termos práticos isso significa que no processo de seleção de parentais o melhorista pode partir de um número maior de materiais e selecionar para cruzamento somente aqueles de melhor padrão individual.

\subsubsection{Capacidade específica de combinação}

A exemplo da CGC, para a CEC quando a estimativa do $s_{i j}$ de um determinado híbrido tem baixo valor absolu to indica que o híbrido se comporta conforme o esperado a partir da CGC de seus parentais, ou seja, hā predominância 
dos efeitos aditivos e possivelmente epistáticos aditivo $\mathrm{x}$ aditivo. Por outro lado, quando a estimativa do $s_{i j}$ de um dado híbrido tem alto valor absoluto (positivo ou negativo) indica que o cruzamento em questão è superior ou inferior ao esperado com base na CGC dos respectivos parentais.

o método 2 de GRIFFING (1956b) inclui os híbridos e os respectivos parentais, desse modo, são apresenta dos os efeitos $s_{i}$, que correspondem a CEC do parental $i$ com ele próprio (Tabela 25) e os efeitos $s_{i j}$ que correspondem a CEC do parental i com o parental j (Tabela 26).

Em soja, alguns autores têm empregado o método 2 (GRIFFING, 1956b) para análise de cruzamentos dialéli cos(BHATADE et alii, 1977; KAW \& MENON, 1980, 1981; SRIVASTAVA et alii, 1978a,b). Entretanto, nenhum desses autores apresentou ou discutiu os efeitos $s_{i i}$. Desse modo, se confirma o fato de que os efeitos $s_{i j}$ ainda carecem de um signi ficado genētico mais realístico (MIRANDA, 1987).

$$
\text { Segundo: Cruz }{ }^{3} \text {, citado por MIRANDA (1987), }
$$

no modelo aditivo-dominante o estimador $s_{i i} \bar{e}$ uma medida da divergência genêtica do parental i em relação à média dos outros parentais incluídos no dialelo. Quanto maior for o

${ }^{3}$ CRUZ, C.D.* Comparação entre alguns métodos de anălise dia lélica. 1987. (em elaboração).

* Professor da Universidade Federal de Viçosa, Viçosa-MG. 
valor absoluto de $s_{i i}$, maior será a divergência genética do parental $i$ em relação aos outros parentais. Quando $s_{i i}$ for negativo, a heterose (medida em relação à média dos parentais) manifestada nos híbridos do parental $\mathbf{i}$, será em média positiva; quando $s_{i i}$ for positivo, a heterose será em média negativa, e quando $s_{i i}$ for zero ou próximo de zero a divergência do parental i em relação aos outros será pequena ou nula e a heterose nos híbridos do parental i será também pequena ou nula.

Nesse estudo para todos os caracteres, as estimativas de $s_{i i}$ apresentaram uma grande variação (Tabela 25).: Interpretando as estimativas de $s_{i i}$ segundo $\mathrm{Cruz}^{3}$, constata-se que há uma considerável divergência entre os parentais. Verifica-se também que nenhum dos parentais apresentou os maiores ou menores valores absolutos de $s_{i i}$ para todos os caracteres. Isso indica que os extremos de divergência são apresentados por diferentes parentais nos diferentes caracteres.

A proporção de valores $s_{i i}$ positivos e negativos variou com o carāter considerado: $7: 3$ (NDF), $8: 2$ (NDM), $6: 4(\mathrm{Ac}), 7: 3(\mathrm{VA})$. Nestes quatro caracteres, a heterose médiar foi negativa (Tabelas 12, 13 e 14). Esta proporção foi 5: 5 na PPI e a heterose më̉ia foi positiva, porém de pequena magnitude $\left(5,2 \%\right.$; Tabela 15). Predominância de valores $s_{i i}$ negati vas foi observada em outros quatro caracteres: 4:6 (NIF e $\mathrm{NIM}), 2: 8(\mathrm{APF}), 3: 7(\mathrm{APM}), 3: 7$ (PP); nestes quatro caracte- 
res, a heterose média foi positiva (Tabelas 12, 13 e 15). Portanto, estes resultados estão em acordo com as afirmativas de $\mathrm{Cruz}^{3}$.

Para CEC, referente aos efeitos $s_{i j}$ para $i \neq j$, ou seja, que corresponde a um hibrido do cruzamento entre parentais $\mathbf{i}$ e $\mathbf{j}$, para todos os caracteres foi observa da uma ampla variação(Tabela 26). Entretanto, é importante ressaltar que em soja, onde o produto final do melhoramento são linhagens homozigóticas, as quais encerram somente efeitos aditivos e epistáticos aditivo $x$ aditivo, a importância da CEC depende da magnitude da proporção da variância epistā tica aditiva $x$ aditiva que ela contém. Nesse contexto, a CEC, por si só, tem um valor limitado para o processo de seleção. Portanto, a CEC deve ser considerada juntamente com outros parâmetros, tais como a média e a variância do híbrido, caso se trate de uma geração segregante, e a CGC dos res pectivos parentais.

Examinando a CEC "per se", para todos os caracteres, constata-se que nos nove cruzamentos que apresenta ram melhores valores de $s_{i j}$ o que corresponde a $20 \%$ dos cru zamentos do dialelo, a maioria dos parentais têm $g_{i}$ com sinais contrārios, ou seja, um parental tem $g_{i}$ positivo e o ou tro tem $g_{i}$ negativo. Nos casos em que os parentais têm 0 mesmo sinal para $g_{i}$, nem sempre é o sinal que está no nesmo sentido do desejado para a melhoria do caráter. 
Para NDF, visando-se a precocidade, os cruzamentos que apresentaram melhores valores para $s_{i j}$ foram Primavera x Palmetto, Hale 321 x Palmetto, coker 136 x Palmetto, FT 81-1835 x Hale 321 e IAC-Foscarin-31 x Coker 136, respectivamente com $-2,666 ;-1,491 ;-1,348 ;-1,294$ e $-1,052$ dias. Desses cruzamentos, os mais precoces, nos quais pelo menos um parental apresentou $g_{i}$ para precocidade (negativo) e tem variâncias em torno da média da variância dos híbridos do dialelo, são FT 81-1835 x Hale 321 e IAC-Foscarin-31 x Coker 136. Um outro cruzamento que apresenta potencial para preco cidade é IAC-Foscarin-3l x Paraná, o qual apresenta $s_{i j}$ igual -1,023 dias e níveis médios dos outros parâmetros considerados.

No carāter NIF, as maiores estimativas de $\mathbf{s}_{i j}$ foram apresentadas pelos cruzamentos Primavera x FT 81-1835, Década x Palmetto, Primavera x Década, Forrest x Hale 321 e IAC-Foscarin-31 x Forrest, respectivamente com 0,11; 0,088; 0,$075 ; 0,061$ e 0,061 (dados transformados para $\sqrt{x+1}$ ). $E$ importante observar que dos sete parentais envolvidos nesses cruzamentos apenas Primavera e Palmetto apresentaram $g_{i}$ posi tivos (Tabela 24). Em todos os outros cruzamentos em que tais parentais participaram, embora nem sempre apresentando altos valores para $s_{i j}$, geralmente apresentaram médias e variâncias superiores, ou pelo menos no mesmo nível dos outros cruzamentos (Tabela 12). 
Para APF, os cruzamentos Forrest $x$ Hale 321 , Coker 136 x FT 81-1835, Primavera x Década, Primavera x SOC 81-79 e Paraná x IAC-Foscarin-31, apresentaram as maiores es timativas de $s_{i j}$ ' respectivamente 4,$108 ; 3,470 ; 2,958 ; 2,714$ e 2,644 cm. Constata-se que esses cinco cruzamentos envolvem nove dos dez parentais usados no estudo e que o parental Palmetto, justamente o que apresentou a maior estimativa para $g_{i}(8,351 \mathrm{~cm})$ (Tabela 24) não participou de nunhum deles. Tambēm o cultivar Paraná que apresentou o segundo maior $g_{i}$ $(2,159 \mathrm{~cm})$ entrou apenas em um desses cruzamentos, exatamente o que mostrou o menor valor para $s_{i j}$. Esses cruzamentos também não se destacaram em termos de média nem de variância. Por outro lado, há cruzamentos que apresentaram efeitos $s_{i j}$ mais baixos como Paraná x Palmetto, Forrest x Palmetto e Pri mavera $x$ Palmetto, nos quais ambos os parentais apresentaram $g_{i}$ positivos (Tabela 24) e médias e variâncias bem maiores que esses cinco cruzamentos citados (Tabela 12).

Com relação ao NDM, objetivando-se a precocidade, constata-se que a maioria dos cruzamentos apresentou efeitos $s_{i j}$ negativos, o que está em acordo com a tendência de dominância observada para precocidade (heterose média negativa, Tabela 13). Os cruzamentos Paraná x IAC-Foscarin-31 com estimativa de $s_{i j}$ de $-5,686$ dias, Paraná $x$ Década de -3,850 dias, Paraná x Forrest de $-3,414$ dias, Hale 321 x Pal metto de -3,364 dias e Paraná x Palmetto de -2,669 dias, fo- 
ram os que apresentaram os menores efeitos da CEC. Todos es ses cruzamentos foram mais precoces que a mëdia dos híbridos para esse caráter, mas somente o cruzamento Paraná x Palmetto apresentou variância superior à média da variância dos cruzamentos (Tabela 13). Em todos esses cruzamentos pelo menos um parental apresentou $g_{i}$ negativo e no cruzamento $\mathrm{Pa}-$ ranā $x$ Década ámbos os parentais tiveram o efeito da CGC negativo. Este cruzamento inclusive foi o mais precoce desses cinco. Esses cruzamentos reunem seis dos dez parentais em estudo, embora apresentando variâncias relativamente baixas estão entre os que apresentam melhores perspectivas para a formação de uma população bāsica para seleção para precocida de para maturidade.

No NIM houve predominância de estimativas de $\mathbf{s}_{\text {ij }}$ positivas. Os cruzamentos Forrest $x$ Hale 321 , Forrest $x$ FT 81-1835, Paraná x SOC 81-79, Primavera x Hale 321. e Coker 136 x Palmetto apresentaram as cinco maiores estimativas de $\mathbf{s}_{i j}$ ' respectivamente 0,$28 ; 0,190 ; 0,180 ; 0,170$ e 0,116 (dados transformados para $\sqrt{x+1}$ ) . Em nenhum desses cruzamentos os dois parentais apresentaram efeitos da CGC positivos e somente os dois ültimos apresentarm média superior à média dos cruzamentos do dialelo; apenas o penúltimo teve uma variância consideravelmente superior à média das variâncias dos cruzamentos (Tabelá 13). Esses cinco cruzamentos envolveram oito dos dez parentais, quatro com $g_{i}$ positivos e quatro com $g_{j}$ negativos. Observa-se que no cruzamento Forrest $x$ 
Hale 321 , que apresentou o maior efeito $s_{i j}$ os dois parentais tiveram efeitos da CGC negativos, respectivamente o segundo menor e o menor valor de $g_{i}$ (Tabela 24). Há portanto, outros cruzamentos como IAC-Foscarin-3I x SOC 81-79, IAC-FO carin-31 x Palmetto, Primavera x Palmetto e SoC 81-79 x Palmetto, os quais envolvem parentais com efeitos da CGC posití vos e que apresentaram médias e variâncias iguais ou superio res à media dos cruzamentos do dialelo.

No carāter APM, houve uma pequena vantagem do nûmero de estimativas de $s_{i j}$ positivas sobre as negativas. As maiores estimativas de $s_{i j}$ foram apresentadas pelos cruza mentos Forrest $x$ Hale 321, Primavera x Hale 321, Paraná $x$ SOC 81-79, Forrest x SOC 81-79 e Forrest x FT 81-1835, respectivamente 18,$45 ; 9,25 ; 8,55 ; 8,03$ e $7,96 \mathrm{~cm}$. Com exceção do primeiro cruzamento, em que ambos os parentais apresenta ram $g_{i}$ negativos, portanto contraŕios ao aumento da expressão da APM, nos demais pelo menos um parental teve $g_{i}$ positi vo (Tabela 24). Também, é importante observar que.o primeiro cruzamento é o único em que os dois parentais têm crescimento determinado e também o que apresentou a menor média de altura dentre os cinco cruzamentos. Todos apresentaram variância aproximadamente igual ou superior à média da variância de todos os cruzamentos (Tabela 13). Há, portanto, outros cruzamentos que apresentaram efeitos de $s_{i j}$ mais baixos, como IAC-Foscarin-3l x Palmetto e até negativos como IAC- 
Foscarin-31 x Primavera e IAC-Foscarin-31 x FT 81-1835, nos quais os efeitos da CGC, em ambos os parentais, foram positi vos e que tiveram médias de altura de planta superiores às dos cinco cruzamentos que apresentaram os maiores efeitos $\mathbf{s}_{i j}$. Tambēm as variâncias desses cruzamentos situaram-se em torno da média das variâncias dos cruzamentos dialélicos (Tabela 13). Desse modo, se mostram com maior potencial para melhorar a APM do que aqueles que apresentam os maiores valores de $s_{i j}$.

Para o caráter Ac os cruzamentos Paraná x IAC Foscarin-31, IAC-Foscarin-31 x Década e Primavera x Palmetto, apresetaram os melhores valores de $s_{i j}$, respectivament $-0,111$; $-0,103 ;-0,1077 ;-0,066$ e $-0,062$. (dados transformados para $\sqrt{x+1}$ ). Esses cruzamentos envolveram sete parentais e todos eles reuniram um parental com $g_{i}$ positivo e outro com $g_{i}$ negativo. Com exceção do cruzamento IAC-Foscarin-3l x Década, os demais apresentaram média de Ac inferior à média dos cruzamentos do dialelo; as variâncias ficaram em torno da média das variâncias dos cruzamentos, com exceção do cruzamento FT 81-1835 x palmetto. O Ac é um caráter que tem limite mínimo 1,0, o qual corresponde à nota da escala que é atribuída a uma planta completamente ereta. Sendo assim, para cruzamentos que apresentaram média de Ac próxima de 1,0, as variâncias deverão ser naturalmente baixas. Desse modo, hã cruzamentos como Paranā x Coker 136, Coker 136 x Hale 321, Década x FT 81-1835 que embora tendo 
apresentado $s_{i j}$ maiores e até positivos, tiveram média de Ac de 1,01 e variância bastante menores que a média do dialelo (Tabela 14). Além disso, en todos eles, os dois parentais tồn $g_{i}$ negativos (Tabela 24), ou seja, no sentido de reduzir - Ac. Desse modo, se mostram mais promissores para serem uti lizados no melhoramento para resistència ao Ac.

No carăter VA em quatro dos cinco cruzamentos que apresentaram os maiores valores de $s_{i j}$, os parentais tive ram $g_{i}$ com o mesmo sinal; nos cruzamentos IAC-Foscarin-31 $x$ Coker 136, Paraná x Forrest e IAC-Foscarin-31 x SOC 81-79, que apresentaram respectivamente $s_{i j}$ de 0,094; 0,0778 e 0,065 (da dos transformados para $\sqrt{\mathrm{x}+1}$, todos os parentais tiveram $g_{i}$ negativos; no cruzamento Primavera x Década que apresentou $s_{i j} d e 0,059$, os dois parentais tiveram $g_{i}$ positivos. No quin to cruzamento (Paraná $x$ SOC 81-79) que apresentou .... ij $_{\text {j }}$ de 0,082 , os parentais apresentaram $g_{i}$ negativo (Paraná) e positivo (SOC 81-79) (Tabela 24). Constata-se que desses cinco cruzamentos os que apresentaram as maiores médias de VA foram aqueles nos quais ambos os parentais tiveram $g_{i}$ positivos (Paraná $x$ Década) ou diferentes (Paraná $x$ SOC 81-79). Inclusive foram esses dois cruzamentos que apresentaram as maiores médias do carāter no dialelo. Outros cruzamentos que apresentaram médias relativamente al- 
tas foram Primavera x SOC 81-79 e Primavera x Hale 321 (Tabe la 14): no primeiro cruzamento, os dois parentais tên $g_{i}$ positivos; no segundo cruzamento somente o parental primavera.

Na avaliação da PPI, dos nove cruzamentos que apresentaram os maiores valores para $s_{i j}$ ' sete envolveram pa rentais com sinais diferentes para $g_{i}$ e dois tiveram parentais com $g_{i}$ de sinais iguais, porém negativos (contrários ao aumento da expressão do caráter). Os cinco cruzamentos que apresentaram os maiores efeitos para CEC foram Primavera $\mathrm{x}$ FT 81-1835, IAC-Foscarin-31 x Forrest, Paraná x SOC 81-79, Primavera x Hale 321 e Década x Palmetto, respectivamente com os valores de $s_{i j}$ de 21,$9 ; 10,7 ; 8,2 ; 7,8$ e 7,6 g/planta. To dos esses cruzamentos a presentaram médias superiores à mëdia ge ral dos cruzamentos e com exceção do cruzamento primavera $x$ Hale 32l, tiveram variâncias maiores que a média das variâncias do dialelo (Tabela 15). Vale observar entretanto, que há outros cruzamentos como IAC-Foscarin-3l x Palmetto, IACFoscarin-31 x SOC 81-79, IAC-Foscarin-31 x Década, SOC 81-79 x Palmetto, IAC-Foscarin-31 x Coker 136 que, embora apresentando baixos efeitos de CEC, apresentaram mëdia de PPI e particularmente variâncias no nível ou superiores aos dos cruzamentos que apresentaram os maiores efeitos de CEC. Cons tata-se que nesses cruzamentos citados, particularmente nesse ültimo grupo, sobressaíram-se os parentais IAC-Foscarin 31, SOC 81-79 e Palmetto. Esses parentais inclusive foram os que apresentaram as majores estimativas de $g_{i}$ para PPI (Tabela 24). 
Na avaliação da PP, expressa em $\mathrm{kg} / \mathrm{ha}$, entre os nove cruzamentos que apresentaram os maiores valores para $s_{i j}$ somente dois estavam entre os nove que apresentaram os maiores $s_{i j}$ para PPI. Para esse caráter, os maiores valores de $s_{i j}$ foram apresentados pelos cruzamentos forrest $x$ Hale 321, Paraná x SOC 81-79, Forrest x Palmetto, Década x SOC 81-79 e Coker 136 x Primavera, respectivamente 635, 485, 459, 457 e $391 \mathrm{~kg} / \mathrm{ha}$. Com exceção do primeiro cruzamento, no qual os dois parentais apresentaram efeitos da CGC negativos, nos demais pelo menos um parental teve $g_{i}$ positivo; nos dois últi mos cruzamentos os dois parentais tiveram efeito da CGC posi tivos (Tabela 24). Todos esses cruzamentos apresentaram médias superiores à média geral do dialelo. Aqui se repete o que aconteceu na avaliação anterior, ou seja, há vários outros cruzamentos que embora tendo $s_{i j}$ mais baixos do que esses relacionados, apresentaram produtividade no mesmo nível da deles e inclusive confirmando o comportamento apresentado ao nível de planta individual. São praticamente os mesmos cruzamentos relacionados no caráter anterior. IAC-Foscarin$31 \times$ Forrest, IAC-Foscarin-31 x Primavera, IAC-Foscarin-31 x SOC 81-79, IAC-Foscarin-31 x Palmetto, SOC 81-79 x Palmetto, Primavera x SOC 81-79. Esta avaliação envolveu toda a parce la e nela não foi estimada a variância existente dentro de cada cruzamento. Entretanto, considerando a média, consta-ta-se que os parentais IAC-Foscarin-31, Palmetto, SOC 81-79 e Primavera, participaram dos melhores cruzamentos, tanto em 
PPI quanto em PP (Tabela 15). Além disso, foram os únicos parentais que apresentaram $g_{i}$ positivos nas duas avaliações da produtividade. Desse modo, esses parentais e os cruzamen tos dos quais eles participaram, particularmente os aqui men cionados, mostram-se como os mais promissores para o melhora mento para produtividade.

Nessa avaliação da CEC verifica-se que para todos os caracteres, a maioria dos cruzamentos que apresentou os maiores efeitos $s_{i j}$ reuniram um parental com efeito da CGC positivo e outro negativo. Embora não se considerando a mag nitude desses efeitos, isso sugere que os altos valores de $s_{i j}$, pelo menos em parte, devem ser decorrentes da divergència entre os parentais. Neste estudo as maiores estimativas de $s_{i j}$ para a maioria dos caracteres, nem sempre estiveram relacionadas às maiores médias, estimativas de $g_{i}$ ou variân cias. De modo que a CEC mostrou-se de pouco valor para a identificação dos melhores parentais e cruzamentos.

A CEC como foi mostrado por GRIFFING (1956a) e KEMPTHORNE \& CURNOW (196I) è dependente da variância devido à dominância e de vários componentes da interação epistática, entre os quais se inclui a aditiva $x$ aditiva. Em soja, que è uma espécie autógama, na qual o objetivo final do melhoramento è a obtenção de linahgens homozigóticas, a importância da CEC depende da magnitude da contribuição da interação epistática aditiva $x$ aditiva que ela contēm. HANSON \& WEBER (1961, 1962) e HANSON et alii (1967) obtiveram resul 
tados a partir de materiais com alto nível de homozigose nos quais a contribuição da epistasia aditiva $\mathbf{x}$ aditiva para a variância genētica total foi relativamente alta para vários caracteres, sendo para produtividade em torno de $70 \%$. Caso esses resultados possam ser extrapolados para a espécie como um todo, i a CEC e a epistasia dever merecer maior atenção em soja.

Porém, è importante mencionar que a epistasia depende da interação interalélica; devido a isto, é instāvel em gerações segregantes, podendo ter seus efeitos anulados com a segregação. Desse modo, para se explurar melhor os efeitos da CEC em soja, as avaliações da capacidade de combí nação devem ser realizadas em gerações mais avançadas. Em ní veis mais altos de homozigose uma maior porcentagem de locos já se encontra en estado homozigótico e a magnitude da CEC dependenrá mais da contribuição da epistasia aditiva x aditi va

\subsection{Cruzamentos em cadeia}

A eficiência do esquema de cruzamentos em cadeia (circular) foi avaliada en relação ao esquema dialélico. O dialelo foi representado por 45 progênies $\mathrm{F}_{2}$ ' enquanto que cada esquema em cadeia correspondeu 10 progênies $\mathrm{F}_{2}$. Esta última diferença é conseqüência do menor número de cruzamentos empregados no esquema em cadeia, fato que se constitui na principal vantagem da aplicabilidade dos cruzamentos em 
cadeia na recombinação em programas de melhoramento de espécies autógamas. Embora o número de progênies seja menor no esquema em cadeia, tanto cadeia quanto dialelo envolvem os mesmos dez parentais. Geneticamente, os dois esquemas são diferenciados pelo número de combinações bi parentais envolví das; esta diferença tende a desaparecer ao longo de vărias (geralmente três) gerações de recombinação de plantas $F_{1}$, pe la realização de cruzamentos de parentais diferentes em cada geração.

Cada um dos cinco esquemas em cadeia $\left(C_{k}\right.$, com $k=1$ a 5) envolveu em torno de 600 plantas, compreendendo apro ximadamente 60 plantas de cada progênie $F_{2}$. Este é um nümero bastante razoável, pois as recomendações para tamanho efe tivo tèm sido ao redor de 30 (BAKER et alii, 1968; BAKER \& CURNOW, 1969; BRIM \& STUBER, 1973). Os resultados das compa rações entre os esquemas de cruzamento em dialelo e em cadeia para o caráter PPI são apresentados na Tabela 27.

A méédia da PPI do dialelo foi de $38,20 \mathrm{~g} / \mathrm{plan}$ ta, média esta que não diferiu da média dos parentais pelo teste "F" (Tabela 11); e nem da média das cadeias $C_{2}, C_{3}$ e $C_{4}$, entretanto, foi superior à média da $\tau_{1}$ e inferior à média de $C_{5}$ pelo teste " $t "$ a $1 \%$. Esses resultados sugerem que essas cadeias amostradas, em termos de média, respresentaram satis fatoriamente o dialelo. Essa conclusão também è válida em termos de amplitude de variação de PPI. Embora nenhuma ca- 
deia tenha incluído o cruzamento Paraná x Hale 321 ( 1 x 9), que apresentou a planta mais produtiva (127 g), com exceção da $\mathrm{C}_{3}$, todas apresentaram plantas com produtividade superior a $110 \mathrm{~g}$. Vale mencionar que em todo dialelo somente sej.s plantas ultrapassaram este valor.

A variância fenotípica do dialelo foi de 425 $(\mathrm{g} / \mathrm{planta})^{2}$ e das cadeias variaram de $355\left(\mathrm{C}_{1}\right)$ a $484(\mathrm{~g} / \mathrm{planta})^{2}\left(\mathrm{C}_{5}\right)$. Portanto, as variâncias fenotipicas das cadeias distribuiram-se em torno da variância do dialelo e não houve diferenças marcantes entre as estimativas. Pode-se admitir que as variâncias das cadeias representaram satisfatoriamente a variância do dialelo.

Os coeficientes de variação genética (CVG) das cadeias, a exemplo da variância fenotípica, se distribuiram em torno do CVG do dialelo. Entretanto, $O$ CVG $=24,4 \%$ da $C_{1}$ foi relativamente inferior ao $\mathrm{CVG}=31,4 \%$ do dialelo; relati vamente, $C_{1}$ mostrou 77,6\% do CVG do dialelo, representando uma perda ou não liberaçãode vaxiabilidade de 22,4\% em PPI. Nas ou tras cadeias, as diferenças para menos em valor relativo foram infe riores a $10 \%\left(\begin{array}{lll}C_{3} & \text { e } & C_{1_{+}}\end{array}\right)$e nas cadeias $C_{2}$ e $C_{5} \circ$ CVG foi superior ao do dialelo, repsectivamente em 12,2 e $8,8 \%$.

Na Figura 7, são apresentadas as curvas de distribuição de freqüència do dialelo, da cadeia $c_{1}$ que apre sentou as menores média, variância fenotípica e CVG, eda cadeia $C_{5}$ que apresentou as maiores média e variância fenotí 
típica e o segundo maior CVG e ainda uma curva média das cin co cadeias apresentadas na Tabela 27. Constata-se nessa figura que as cadeias embora reunindo um número menor de cruza mentos e conseqüentemente um número menor de plantas, apresentam praticamente todos os niveis de produtividade apresen tados pelo dialelo. Isso não significa que as cadeias contêm todos os genótipos existentes no dialelo, mas sim que elas contêm genótipos equivalentes em potencial produtivo aos existentes no dialelo. Como as cadeias reúnem os mesmos parentais do dialelo elas devem ter uma reserva de variabilida de semelhante a do dialelo, a qual pode ser liberada com os ciclos sucessivos de intercruzamentos.

Os resultados deste estucio, sugerem que em termos de mëdia, níveis e amplitude de produtividade, variân cia fenotípica e CVG o esquema de cruzamento em cadeia representou bem o esquema dialélico. Em termos apliciados, pode-se considerar que no esquema em cadeia se obtên variabili dade inicial equivalente à obtida no esquema dialélico.

Alguns autores têm apresentacio argumentos con tra o uso de intercruzamentos em gerações iniciais em espécies autógamas como a soja (BOS, 1977 e PEDERSON, 1974). En tretanto, para o melhorista dessas espécies não há muita opção para obter variabilidade mais ampla que a fornecida pelo cruzamento bi parental e para criar condições para uma ampla segregação, quebra de ligações e surgimento de novas combina 
ções gênicas. Assim o melhorista fica diante praticamente de duas opções: a) ou explorar satisfatoriamente a variabili dade relativamente restrita nos cruzamentos biparentais; ou b) explorar com uma certa limitação a variabilidade mais ampla obtida de esquemas de cruzamentos que envolvem vários parentais. Atualmente, parece haver uma tendência de preferência pela segunda alternativa.

Esquemas de cruzamento envolvendo intercruzamentos em gerações iniciais têm sido sugeridos por värios au tores como Harlan et alii $(1940)^{4}$ e Mackey (1954) ${ }^{5}$, citados por FREY (1976), FOUILLOUX (1983), JENSEN (1978) è JOSHI (1979). Outros autores têm usado esquemas de cruzamentos envolvendo vārios parentais para a formação de populações bā sicas para seleção recorrente en várias culturas, como soja (FEHR \& HORTIZ, 1975; KENWORTHY \& BRIM, 1979; SUMARNO, 1981; VELLO et alii, 1984; WALKER \& SCHIMITTHENNER, 1984; PROHASKA \& FEHR, 1981); trigo (MCNEAL et alii,1978; LOFFLER et alii, 1983; BUSCH \& KOFOID, 1982); e feijão KELLY \& ADAMS, 1987; TOLLA \& BLISS, 1977 ).

Reconhecidamente uma das dificuldades maiores em plantas autōgamas è a formação da população bāsica com

4 HARIAN, H.V.; MARTINE, M.I.; STEVENS, H.A. A study of methods in breeding. USDA. Technical Bulletin, Washington, 720: 1-2, 1940 .

5 MACKEY, J. Breeding of oats. Handbuch fur Pflanzenzlichtung, 2: $512-17,1954$. 
ampla variabilidade genética, porque geralmente requer um grande nümero de cruzamentos. Nesse aspecto o esquema em cá deia mostra-se bastante vantajoso, pois requer em cada ciclo um nümero mínimo de cruzamentos para $\mathbf{n}$ parentais. Na Figura 8, é apresentado um esquema para formação de uma população básica, a partir de dez parentais, usando cruzamentos em cadeia nos ciclos iniciais de cruzamento. Constata-se nessa figura que no terceiro ciclo de cruzamentos as dez progènies $F_{1}$ são combinadas em cinco cruzamentos e todos parentais têm participações iguais na formação das progênies $F_{l}^{\prime \prime}$, ou seja, cada parental entra na formação de quatro $F_{I}$. Isso assegura que, desde que a amostragem seja bem feita, em termos de material genético todos estarão iguaimente representa dos na população básica. 


\section{CONCLUSÕES}

As conclusões seguintes Eoram obtidas dos resultados da anälise estatístico-genētica de um dialelo com dez parentais e 45 progênies $F_{2}$ de soja precoce avaliadas pạ ra dez caracteres: nūmero de dias no florescimento (NDF) e na maturação (NDM), nūmero de internçdios no florescímento (NIF) e na maturação (NIM), altura da planta no florescimento (APF) e na maturação $(A P M)$, valor agronômico (VA), acamamento (AC), produtividade de pianta indiviaual (PPI) e de parcela (PP).

a) A quantidade de variablidade genētica foi variável entre os cruzamentos e entre os caracteres; nenhum cruza mento apresentou variância superior para todos os caracteres, indicando que os parentajs têm.. caracterís ticas complementares.

b) A heterose ea heterobeltiose apresentaram uma ampla variação; nem sempre as maiores heteroses e heterobeltioses estiveram relacionadas às maiores mëdias e variâncias. Em termos de $\mathrm{PP}$, nenhuma progênie $F_{2}$ superou 0 parental mais produtivo IAC-Foscarin-31, de maneira que não se detectou heterose padrão para $\mathrm{PP}$ em $\mathrm{F}_{2}$. 
c) As correlações foram concordantes para parentais e pro gênies $\mathrm{F}_{2}$. As correlações genotípicas tenderam a ser maiores que as fenotípicas e as de ambiente. A correlação entre PPI e PP foi positiva, mas de pequena magnitude.

d) Os caracteres relacionados à maturação (NDM, NIM e APM) mostraram-se altamente correlacionados entre si e com a produtividade, podendo ser muito üteis no melhoramen to deste carāter.

e) Na maioria dos caracteres os dados não atenderam plena mente às restrições do modelo de Hayman. A anālise gráfica revelou sobredominância em todos os caracteres; para a maioria dos caracteres. não foi possivel estimar - limite teórico de seleção. A anālise numërica detec tou sobredominância só em NDM, VA e PP; as variâncias aditivas foram significativas em todos os caractexes; as variâncias de dominância foram significativas em NDF, NDM, NIM, APM, VA e PP.

f) Os coeficientes de herdabilidade no sentido amplo foram superiores a 0,80 para todos os caracteres, com exceção do Ac onde não foi possīvel estimā-lo. Aș her dabilidades no sentido restrito foram variāveis em mag nitude: $\operatorname{PP}(0,13), \operatorname{VP}(0,29), \operatorname{APM}(0,34), \operatorname{PPI}(0,32), A P M$ $(0,34), \operatorname{NIM}(0,65), \operatorname{NDM}(0,67), \operatorname{NDF}(0,71), \operatorname{NIF}(0,87)$ e $\operatorname{APF}(0,88)$.

g) A anālise de Griffing mostrou que tanto capacidade geral de combinação (CGC) quanto capacidade específica de combinação ( $C E C^{\prime}$ ) foram muito variāveis entre os caracteres. Os maiores valores de $g_{i}$ ocorreram em paren tais diferentes, indicando a complementação de caracte 
res nos parentais. Os maiores valores de $s_{i j}$ foram decorrentes da divergência dos parentais $\left(g_{i}\right.$ com sinais contrārios) e nem sempre estiveram associados com maiores médias e variâncias.

h) Com base nas mëdias e nos efeitos da CGC, os parentais IAC-Foscarin-31, Palmetto, Primavera e SOC 81-79 apresentaram maior potencial para melhoramento da produtividade. Houve destaque para nove cruzamentos bi parentais: IAC-Foscarin-3I x (Década, Coker 136, Primavera, SOC 81-79, Palmetto, Paranā); SOC 81-79 x (Palmetto, Primavera, Paraná).

i) Os parentais apresentaram complementação de caracteres e variabilidade genética em quantidade adequada para formação de população bäsica a ser utilizada em prográ mas de seleção recorrente para desenvolĩimento de genö tipos precoces de alto valor agrorômico.

j) O esquema de cruzamentos em cadeia representou satisía toriamente o esquema de cruzamentos dialélicos em termos de mëdia e variabilidade genettica liberada em $\mathrm{F}_{2}$ ' constituindo-se em uma alternativa de grande aplicabilidade no melhoramento de espécies autógamas, principalmente para sucessivos ciclos de recombinação de parentais ( $\mathrm{n} \geq 10$ ) para formação de populações con base genética ampla a serem usadas em programas de seleção recorrente. 


\section{REFERENCIAS BIBLIOGRÁFICAS}

ANAND, S.C. \& TORRIE, J.H. Heritability of yield and other traits and interrelationships among traists in the $\mathrm{F}_{3}$ and $\mathrm{F}_{4}$ generations of three soybean crosses. Crop Science, Madison, $\underline{3}$ : 508-11, 1963.

ANUÁRIO ESTATISTICO DO BRASIL - 1986. Rio de Janeiro, 47: $282-3,1986$.

ASKEL, R. \& JOHNSON, I.P.V. Analysis of a diallel cross: a worked exemple. Advancing Frontiers of plant Science, New Delhi, 2: 37-53, 1963.

BAKER, R.J. Extent of intermating in self-pollinated species necessary to counteract the effects of genetic drift. Crop Science, Madison, 8: 547-50, 1968.

BAKER, R.J. Issues in diallel analysis. Crop science, Madison, 18(4): 533-6, 1978 .

BAKER, I.H. \& CURNOW, R.N. Choice of population size and use of variation between replicate populatiors in plant breeding selection programas. Crop Science, Madison, 9: 555-10, 1969.

BHATADE, S.S.; SINGH, C.B.; TIWARI, A.S. Diallel analysis of yield and its components in soybean. Indian J.Agric. Sci., New Delhi, 47 (7):322-4, 1977. 
BONATO, E.R. \& BONATO, A.L.V. A soja no Brasil: história e estatística. Londrina, EMBRAPA/CNPSo, 1987. 61p. (Docu mentos, 21).

BONATO, E.R. \& DALL'AGNOLL, A. Soybean in Brazil-production and research. In: WORLD SOYBEAN RESEARCH CONFERENCE, 3 . Ames, 1984. Proceedings. Boulder, Westview Press, 1985. p.1248-56.

BONETTI, L.P. Distribuição da soja no mundo; origem histō ria e distribuição. In: MIYASAKA, S. \& MEDINA, J.C., ed. A soja no Brasil. Campinas, ITAL, 1981. p.l-6.

BOS, I. More arguments against intermating $F_{2}$ plants of a self-fertilizing crop. Euphytica, Wageningen, 26:33-46, 1977 .

BRIM, C.A. Quantitative genetics and breeding. In: BERNARD, R.L. \& WEISS, M.G., ed. Soybeans; improvement production and uses. Madison, American Society of Agronomy, 1973. cp. 5, p. 155-85.

BRIM, C.A. \& COCKERHAM, C.C. Inheritance of quantitative characters in soybeans. Crop Science, Madison, 1: 187-90, 1961 .

BRIM, C.A. \& STUBER, C.W. Application of genetic male sterility to recurrent selection schemes in soybeans. Crop Science, Madison, 13:528-30, 1973.

BURTON, J.W. \& CARTER JR., T.E. A method for production of experimental quantities of hybrid soybean seed. Crop Science, Madison, 23:388-90, 1983.

BUSCH, R.H. \& KOFOID, K. Recurrent selection for kermel weight in spring wheat. Crop Science, Madison, 22 (3) : 568-72, 1982 . 
BYTH, D.E.; WEBER, C.R.; CALDWELL, B.E. Correlated trunca tion selection for yield in soybeans. Crop Science, Madi son, $\underline{9}$ : 699-702, 1969 .

CAMACHO M., L.H. Varianzas geneticas y heredabilidad de caracteristicas vegetativas y reprodutivas de la soya Gly cine max (J.) Merr. Acta Agronômica, Palmira, 21(4);13952, 1971 .

CAMPOS, L.A.C. Estudo da heterose, da heterobeltiose e de correlações de algumas características agronômicas en cru zamentos de soja[(Glycine max (L.) Merrill]. Viçosa,1979. 76 p. (M.S. - Universidade Federal de Viçosa).

CAVINESS, C.E. \& PRONGSIRIVATHANA, C. Inheritance and association of plant height and its components in soybean cross. Crop Science, Madison, 8 (2):221-4, 1968.

CECON, P. R.; SEDIYAMA, C.S.; REGAZZI, A.J.; SEDIYAMA, T. Anâlise das gerações $\mathrm{F}_{2}$ e $\mathrm{F}_{3}$, para estimar variâncias aditivas, de dominância e de ambiente, em um sistema fatorial de cruzamentos em soja. Revista Ceres, Viçosa, $\underline{32}$ $(184): 470-87,1985$.

CHAUDHARY, D.N. \& SINGH, B.B. Heterosis in soybean. Indian J. of Genet. \& Plant Breeding, New Delhi, $3 \underline{3}(1): 69$ - 74, 1974 .

CHAUHAN, V.S. \& SINGH, B.B. Heterosis and genetics variability in relation to genetic divergence in soybean. Indian J. of Genet. \& Plant Breeding, New Delhi, $42(3): 324-8$, 1982 .

CHAUHAN, V.S. \& SINGH, B.B. Genetic variability and heritability in soybean. Indian J. Agric. Sci., New Delhi, 54 (4) : 273-6, 1984 . 
COMSTOCK, R.E. \& ROBINSON, H.F. The components of genetic variance in populations of biparental progenies and their use in estimating the average degree of dominance. Biometrics, Raleigh, $\underline{4}:$ 254-66, 1948 .

CROISSANT, G.L. \& TORRIE, J.H. Evidence of nonadditive effects and linkage in two hybrid populations of soybeans. Crop Science, Madison, 11:675-7, 1971.

CRUz, C.D. Anālise dialélica e correlações entre caracteres em combinações híbridas de linhagens endogamicas de mitho (Zea mays L.). Viçosa, 1983. 54p. (M.S. Universida de Federal de Viçosa).

DESTRO, D.; SEDIYAMA, T.; SILVA, J.C.; SEDIYAMA, C.S.; THIEBAUT, J.T.L. Estimativas de herdabilidade de alguns caracteres em dois cruzamentos de soja. Pesq. Agrop. Bras., Brasilia, 22(3): 291-304, 1987 .

DICKINSON, A.G. \& JINKS, J.C. A generalised analysis of. diallel crosses. Genetics, Austin, 4I(1): 65-78, 1956.

FALCONER, D.S. Introduction to quantitative genetics. Loi-don, Longman, 1977. $365 \mathrm{p}$.

FAO PRODUCTION YEARBOOK - 1985. ROMe, 39:142, 1986.

FARIAS NETO, J.T. de. Comportamento e variabilidade de genó tipos de soja (Glycine max (L.) Merrill) em cultivos de verão e inverno. Piracicaba, 1987. 87p. (M.S. Escola Superior de Agricultura "Luiz de Queiroz"/USP).

FEHR, W.R. \& ORTIZ, L.B. Recurrent selection for yield in soybeans. Journal of Agriculture of Univ. Puerto Rico, Rio Piedras, 59:222-32, 1976. 
FEHR, W.R. \& WEBER, C.R. Mass selection by seed size and specific gravity in soybean populations. Crop Science, Madison, 8: $551.4,1968$.

FERREIRA, P.E. On Jinks-Hayman's analysis of half dialles. Rev. Bras. Genet., Ribeirão Preto, 8 (1): 149-55, 1985.

FREY, K.J. Breeding concepts and techniques for self pollinated crops. Egypt. J. Genet. Cytol., Alexandria, 5: 184$206,1976$.

FOUILLOUX, G. Description and justification of a recurrent breeding program in order to improve dry bean. In: EUCAR PIA MEETING ON PHASEOLUS BEAN BREEDING, Hamburg, 1983. Proceedings. EUCARPIA, 1983. $156 \mathrm{p}$.

GILBERT, N.E.G. Diallel cross in plant breeding. Heredity, Edinburg, $12(4): 477-92,1958$.

GRIFFING, B. A generalised treatment of the use of dialiel crosses in quantitative inheritance. Heredity, Edimburg, $10(1): 31-50,1956 a$.

GRIFFING, B. Concept of general and specific combining ability in relation to diallel crossing sistems. Aust. J. Biol. Sci., Melbourne, $\underline{9}: 462-93,1956 \mathrm{~b}$.

GUPTA; V.P.; SOOD, D.R.; NAINAWATTI, H.S.; WAGIE, D.S. Heri tability and correlation estimates for protein, oil, and crushing hardness in photo-sensitive and insensitive groups of soybean. Soybean Genetics Newsletter, Ames, 7 : $50-5,1980$.

HANSON, N.D. \& WEBER, C.R. Resolution of genetic variability in self-pollinated species with on application to the soybean. Genetics, Austin, 45(11):1425-34, 1961 . 
HANSON, W.D. \& WEBER, C.R. Analysis of genetic variability from generations of plant progeny lines in soybeans. Crop Science, Madison, 2: 63-7, 1962.

HANSON, W.D.; PROBST, A.H.; CALDWELL, B.E. Evaluation of a population of soybean genotypes with implications for improving self-pollinated crops. Crop Science, Madison, 7: 99-103, 1967 .

HARRISON, S.A.; BOERMA, H.R.; ASHLEY, D.R. Heritability of canopy-apparent photossynthesis and its relationship to seed yield in soybeans. Crop Science, Madison, 21: 222 6,1981 .

HAYMAN, B.I. The analysis of variance of diallel tables. Biometrics, Ralejgh, I.0: 235-44, 1954a.

HAYMan, B.I. The thoery and analysis of diallel crosses: Getics, Baltimore, 39(6): 789-809, $1954 \mathrm{~b}$.

HAYMAN, B.I. The theory and anaIysis of diallel crosses: II. Genetics, Austin, $\underline{43}(13): 63-85,1958$.

HIROMOTO, D.M. \& VELLO, N.A. The genetic base of Brazilian soybean (Glycine max (I,) Merrill) cultivars. Rev. Bras. Genet. Ribeirão. Preto, $9(2): 295-306,1986$.

HYMOWIT, T. On the domestication of the soybean. Economic Botany, Lancaster, 24: 408-21, 1970.

JENSEN, N.F. A diallel mating systern for cereal breeding. Crop Science, Madison, 10: 629-35, 1970.

JINRS, J.I. The analysis of continuous variation in a diallel cross of Nicotiana rustica varieties. Genetics, Baltimore, 39(6): 767-88, 1954 .

JINKS, J.I. The $\mathrm{F}_{2}$ and backcross generations from a set of diallel crosses. Heredity, Edinburgh, 10(1): 1-30, 1956. 
JOHNSON, H.W.; ROBINSON, H.F.; COMSTOCK, R.E. Estimates of genetic and environmental variability in soybeans. Agric. Journal, Madison, $\underline{47}$ : 314-18, 1955a.

JOHNSON, H.W.; ROBINSON, H.F.; COMSTOCK, R.E. Genotypic and phenotypic correlations in soybeans and their implications in selection. Agric.Journal, Madison, 47: 477-83, 1955b.

JOSHI, A.B. Breeding methodology for autogamous crops. Indian J. of Genet. \& Plant Breeaing, New Delhi, 39 (3): $567-78,1979$.

KASTER, M. \& BONATO, E.R. Introdução e evolução da soja no Brasil; evolução da cultura da soja no Brasil. In: MIIASAKA, S. \& MEDINA, J.C. ed. A soja no Brasil. Campinas, ITAL, 1981. p. 58-64.

KAW, R.N.\& MENON, r.M. Heterosis in a ten-parental. djallel cross in soybean. Indian J.Agric. Sci., New Delhi: 49 (5): $322-4,1979$.

KAW, R.N. \& MENON, P.M. combining ability in soybean. Indian J. Of Genet. \& Plant Breeding, New Delhi, 40 (I): $305-9,1980$.

KAW, R.N. \& MENON, P.M. Combining ability for developinent traits in soybean. Indian J. of Genet. \& Plant Breeaing, New Delhi, $41(3): 303-8,1981$.

KAW, R.N. \& MENON, P.M. Diallel analysis in soybean. Indian J. Agric. Sci., New Delhi, $52(12): 991-7,1983$.

KELIY, J.D. ¿ ADAMS, M.N。 Phenotypic recurrent selection in ideotype breeding of pinto beans. Euphytica, wageningen, $36: 69-80,3987$. 
KEMPTHORNE, O. An introduction to genetic statistics. Ames, Iowa State University Press, 1969. 545p.

KEMPTHORNE, O. \& CURNOW, R.N. The partial diallel cross. Biometrics, Raleigh, 17(2): 229-50, 1961.

KENWORTH, W.J. \& BRIM, C.A. Recurrent selection in soybeans; I. Seed yield. Crop Science, Madison, 19: 315-8, 1979.

KUNTA, T.; EDWARDS, L.H.; MaeNEW, R.W; DINKINS, R. Heterosis performance and combining ability in soybeans. Soybean Genetics Newslettex, Ames, 12: 97-9, 1985.

KNOW, S.H. \& TORRTE, J.H. Heritability of and interrelationships among traits of two soybean populations. Crop Science, Madison, 4 : 196-8, 1964.

LEFFEL, R.C. \& HANSON, W.D. Early generation testing of diallel crosses of soybeans. Crop science, Madison, I(2): $169-74,1961$.

LEFFEL, R.C. \& WEISS, M.G. Analysis or diallel crosses among ten varieties of soybeans. Agr. Journal, Niadison, 50: $528-34,1958$.

LOFFI.ER, C.M.; BUSCH, R.H.; VIERSMA, J.V. Recurrent selection for grain protein percentage in hard red. spring wheat. Crop Science, Madison, 23: 1087-1.01, 1983.

MAHMiUD, I. \& KRAMER, H. S. Segregation for yield, height, and maturity following a soybean cross. Agr. Journal, Ma dis son, 43 : 605-9, 1951 .

MATHER, K. \& JINKS, J.I. Biometrical genetics; the study of continuous variations. 3. ed. London, Chapman and Hall, 1982. $396 \mathrm{p}$. 
MCNEAL, F.H.; MCGUIRE, C.F.; BER, M.A. Recurxent selection for grain protein content in spring wheat. Crop Science, Madison, 18: 779-82, 1978.

MEHTA, S.K.; LAL, M.S.; BEOHAR, A.B.L. Heterosis in soybean crosses. Indian J. Agric. Sci., New Delhi, 54(8): 682-4, 1984.

MILLER, J.E. \& FEHR, W.R. Direct and indirect recurrent selection of protein in soybeans. Crop Science, Madison, 19: 101-6, 1979 .

MIRANDA, J.E.C. de. Analise genëtica de um cruzamento dialé lico em pimentão (Capsicum annuum L.). Piracicaba, $398 \%$. 159p. (Doutorado - Escola Superior de Agricultura "Luiz de Queiroz"/USP).

MJRANDA EILHO, J.B. Componentes da variäncia gerética em progênies de cruzamentos em cadeia. Relatörio Cientifico do Departamento de Genética, Piracicaba, 16: 77-86, 1982.

NELSON, R:L. \& BERNARD, R.L. Production and performance of hybrid soybeans. Crop Science, Madison, 24: 549-53, 1984.

PANDEY, J.P. \& TORRIE, J.H. Path coeficient analysis of seed yield components in soybeans (Glycine max (L.) Merr.) Crop Science, Madison, 13:505-7, 1973.

PASCHAL II, E.H. \& WIICOX, J.R. Heterosis and combining ability in exotic soybean germoplasm. Crop science, Madi. son, 15: 34tx-9, 1975 .

PEDERSON, D.G. Arguments against intermating before selection in a self-fertilizing species. rheoret. Appl. Geretics, Berlin, 45: 157-62, 1974 . 
PROHASKA, K.R. \& FEHR, W.R. Recurrent selection for resistance to iron defficience chlorosis in soybeans. Crop Science, Madison, 21: 524-26, 1981.

RANZANI, G.; FREIRE, O.; KINJO, T. Carta de solos do municí. pio de Piracicaba. Piracicaba, ESALQ/Centro de Estudos ae Solos, 1966 . 86p. (mimeografado).

SABBOUH, M.Y. \& EDWARDS, L.H. Combining ability for seed protein and oil content in soybean. Soybean Genetics Newsletter, Ames, 12: 103-11, 1985.

SlNT'OS, J.B. dos. Controle genëtico de caracteres agronômicos e potencialidades de cultivares de feijão ( Phaseolus vulgaris L.) para o melhoramento genético. Piracicaba, 1984. 223p. (Doutorado - Escola Superior de Agricultura "Luiz de Queiroz"/USP).

SIMPSON JR., A.M. \& WILCOY, J.R. Genetic and phenotypic associations of agronomic characteristics in four high protein soybean population. Crop Science, Madison, 23: $1077-81,1983$.

SINGH, R.K. \& CHAUDHARY, B.D. Biometrical methods in quantitative genetic analysis. 2.ed. New Delhi, Kalyani Publishexs, 1979. 304p.

SINGH, M. \& SINGH, R.K. Hayman's graphical analysis in segregation genexations of a diallel cross. Biom. Journal, Hissar, 26 (1): 69-74, $1.984 a$.

SINGH, M. \& SINGF, R RK. Some theoretical aspects of analysis in half dizillel. Biom. Journà], Hissar, 26(I): 63-8 $1984 b$.

SINHA, S.K. \& KHANNA, R. Physiological, biochemical, and genetic basis of heterosis. Advances in Agronomy, New York, 27: 123-74, 1975. 
SMITH, R.R. \& WEBER, C.R. Mass selection by specific gravity for protein and oil in soybean populations.

Crop Science, Madison, 8: 373-7, 1968.

SNEDECOR, G.W. \& COCHRAN, :W.G. Metodos estadisticos. 4. 4 . Mexico, Compañia Editorial Continental, 1977. 703p.

SPRAGUE, G.F. \& TATUM, L.A. General vs. specific combining ability in single crosses of corn. J. Amer, Soc. Agron., Geneva, 34(10): 923-32, 1942 .

SRIVASTAVA, R.L.; AHMAD, Z.; SINGH, H.G.; SAXENA, J.K. COMbining ability fox yield and related attributes in soybean. Indian J. Agric., Sci., New Delhi, 48(3): $148 \ldots 55$, $1978 \mathrm{a}$.

SRIVASTAVA, R.L.; SAXENA, J.K.; AHMAD, Z : BHATIA, R.S.GEnetics of yield and yield component traits in soybean. Indian J. of Genet. \& Planta Breeding, New Delhi, 38 (1): $6-10,1978 b$

ST. MARIIN, S.K. Epistasis and soybean breeding.

Soybean Genetics Newsletter, Ames, 8: 104-7, 1981.

STEEL, R.G.D. \& TORRIE, J.H. Principles and proceaures of statistics; a biometrical approach. 2.ed. New York, McGraw-inill Book, 1980.633p.

STUBER, C.W. Mating äesigns, field nursery layouts, and breeäing records. In: FEHR, W.R. \& HADLEY, H.H. ed. Hybridization of crop plants. Madison, American Society of Agronomy/Crop Science Society of Ainerica, 1980. cap.5, p. 83-104.

SUMARNO. Response to recurrent selection for yields improve ment in soybean. Ames, 1981. 103p. (PhD. - Iowa state university). 
TOLEDO, J.F.F. de \& KIIHL, R.A. de S. Anălise do modelo genético envolvido no controle de dias para florescimento em soja. Peśg. Agrop. Bras., Brasília, 17(4): $623-31$, $1982 \mathrm{a}$.

TOLEDO, J.F.F. de \& KIIHL, R.A. de S. Mêtodos de anälise dialélica do modelo genêtico en controle das característi cas dias fara:fioração e nümero de folhas trifoliadas en soja. pesq. Agrop. Bras., Brasilia, I7(5): 745-55, 1982b.

TOLLA, G. \& BLISS, F.A. Recurrent selection in bean improve ment. Bean Improvement Cooperative and National Dry Bean. Counci1., 8-10: 46-7, 1977.

VELLO, N.A. Efeitos da introciução de germoplasma exótico sobre a produtividade e relações corn a base genëtica dos cultivares de soja [Glycine max (I.) Merrill]. Piracicaba, 1985. 91p. (Livre-Docência - Escola superior de Agricultura "Luiz de Queiroz"/USP).

VELLO, N.A.; FEHR, W.R.; BAHRENFUS, J.B. Genetic varjabili ty and agrononic performance of soybean populations developed from plant introductions. Crop Science, Madison, 24: 511-4, 1984.

VEATCH, C. Vigor in soybeans as affected by hybridity. J. Amer. Soc. Agron., Washingion, 22(4): 289-310, 1930.

VENCOVSKY, R. Herança quantitativa. In: PATERNIANI, E., coord. Melhoramento e produção do milho no Brasil. Campinas, Fundação Cargill, 1978. p. 122-201.

VIRMANI; S.S. \& EDWARDS, I.B. Current status and future prospects for breeding hybrid rice and wheat. Advances in Agronomy, New York, 36: 145-215, 1983. 
WALKER, A.K. \& SCHMITTHENNER, A.F. Recurrent selection for tolerance to Phytophthora not in soybean. Crop Scjence, Ma dison, 24(3): 495-7, 1984 .

WEBER, C.R.; EMPIG, L.T.; THORNE, J.C. Heterotic performance and combining ability of two-way $F_{I}$ soybean hybrids. Crop Science, Mađison, 10: 159-60, 1970.

WEISS, M.G.; WEBER, C.R.; KAITON, R.R. Early generation testing in soybeans. J. Amer. Soc. Agron., Geneva, 39: 79l-81l, 1947 .

WENTZ, J.B. \& STEWART, R.T. Hybrid vigor in soybeans. I. Amer. Soc. Agron., Madison, 16 (8):534-40, 1924.

WOODWORTH, C.M. Genetics of soybean. J. Amerc. Soc. Agron., Washington, 25:36-51, 1933. 
MREFTAS 


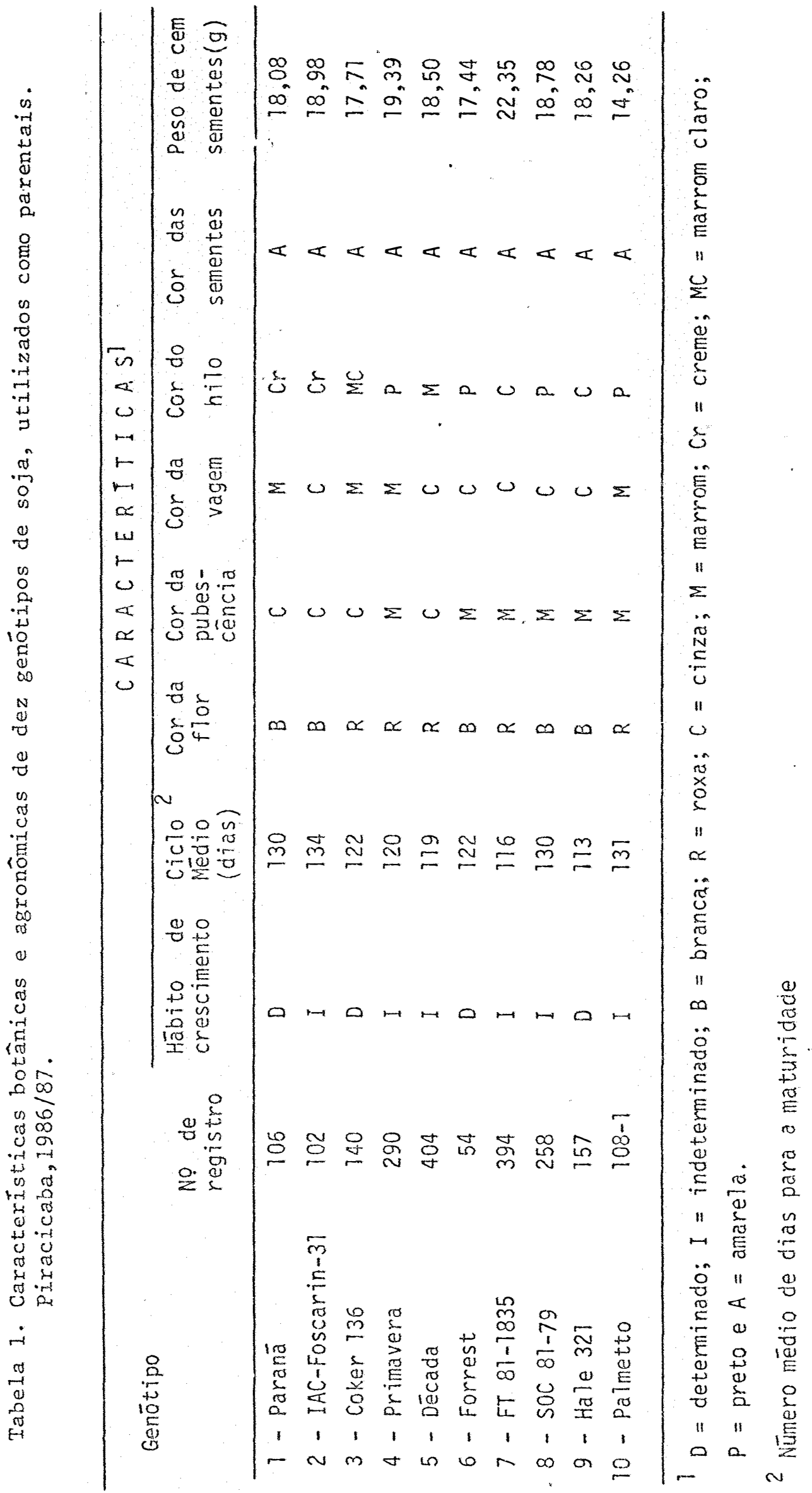




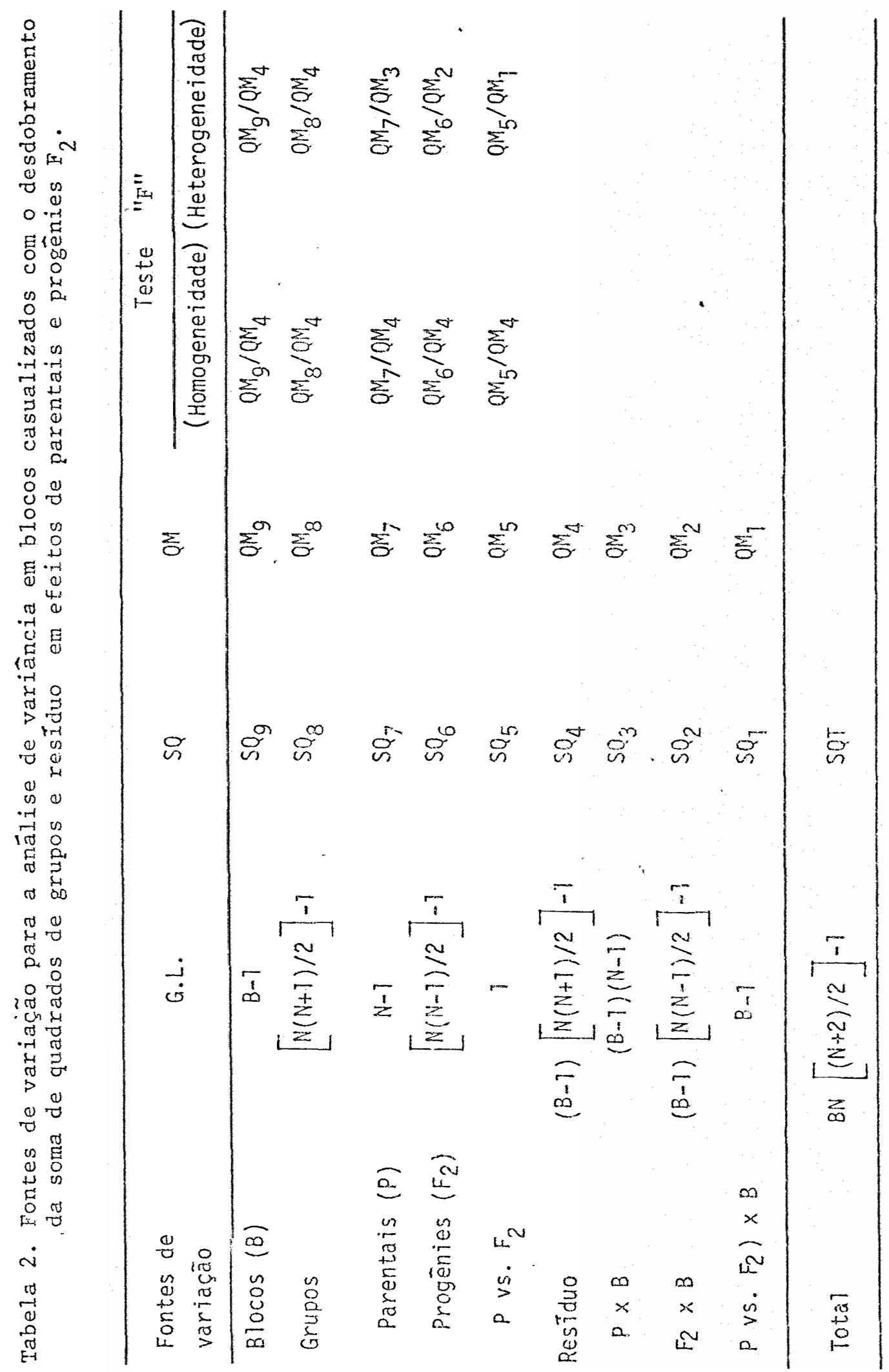


181.

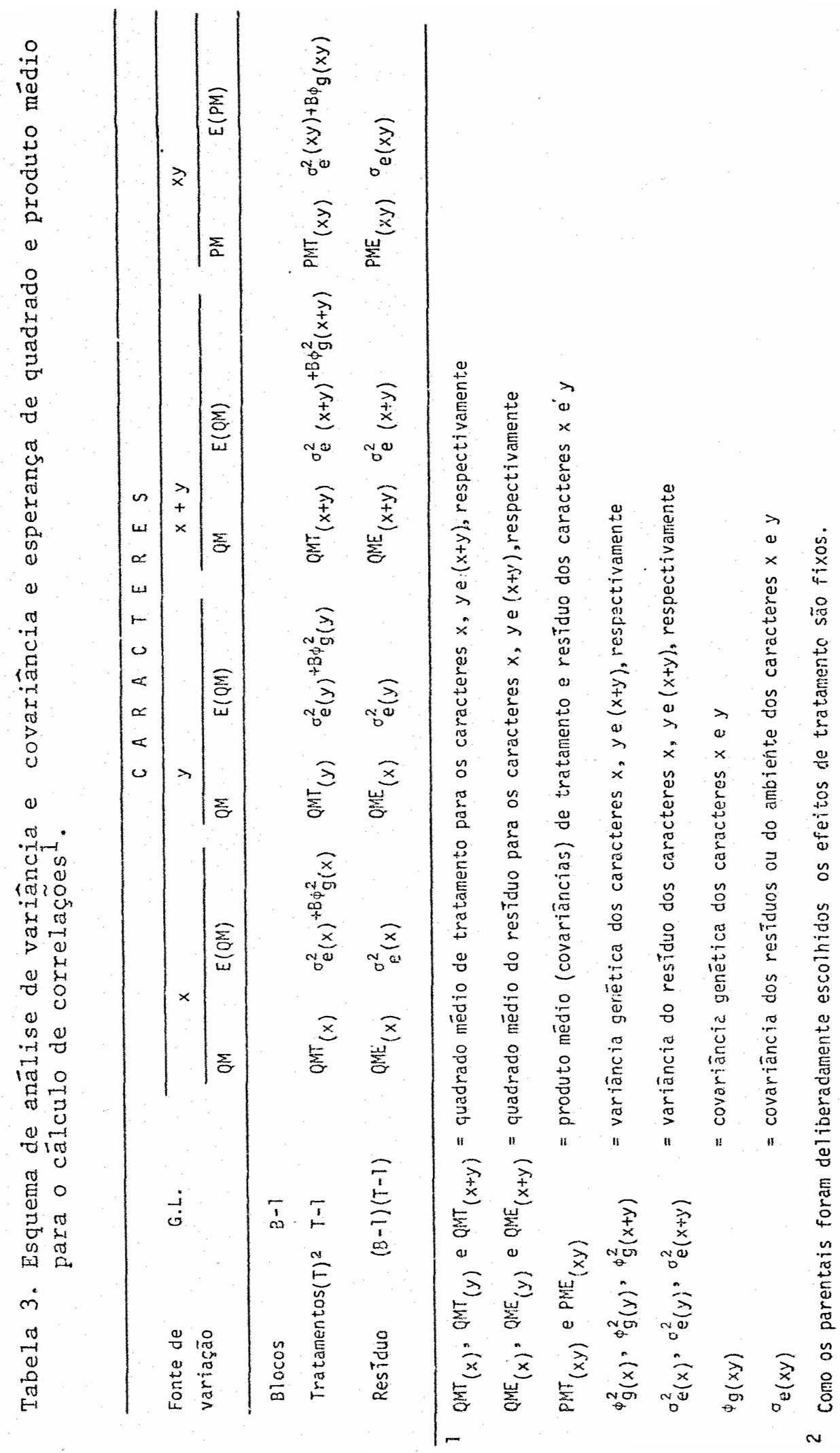




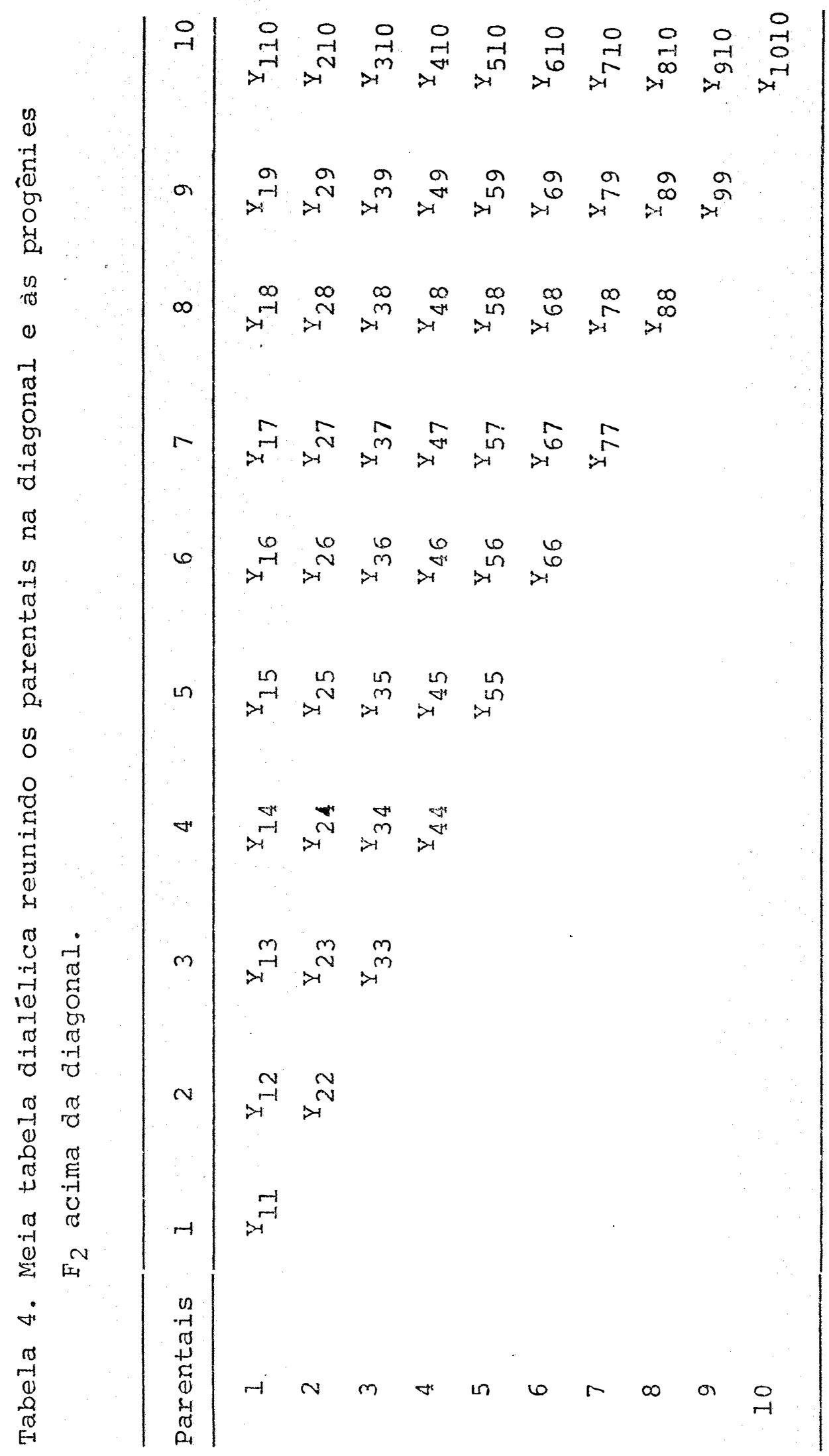


Tabela 5. Anālise de variância pelo método 2, modelo misto B de GRIFFING (1956b).

\begin{tabular}{|c|c|c|c|c|c|c|}
\hline F.V. & G.L. & SQ & $\mathrm{QM}$ & $E(Q M)$ & & $F$ \\
\hline \multirow[t]{2}{*}{$\operatorname{CCC}$} & \multirow[t]{2}{*}{$n-1$} & \multirow{2}{*}{$\mathrm{SQ}_{\mathrm{g}}$} & \multirow{2}{*}{$Q M_{g}$} & \multirow{2}{*}{$\sigma^{2}+\frac{(n+2)}{(n-1)}$} & \multirow{2}{*}{$\Sigma g_{i}^{2}$} & $\mathrm{~m}_{\mathrm{g}}$ \\
\hline & & & & & & $Q \mathrm{M}^{i}$ \\
\hline \multirow{2}{*}{ CEC } & $n(n-1)$ & \multirow[b]{2}{*}{$\mathrm{SQ}_{\mathrm{S}}$} & \multirow[b]{2}{*}{$\mathrm{OM}_{\mathrm{S}}$} & \multirow{2}{*}{$\sigma^{2}+\frac{2}{n(n-1)}$} & \multirow{2}{*}{$\begin{array}{l}\sum_{s i j} j^{2} \\
\dot{i} \leq j\end{array}$} & $\stackrel{Q M_{s}}{ }$ \\
\hline & 2 & & & & & $Q e^{\prime}$ \\
\hline \multirow[t]{2}{*}{ Resĩduo } & $(r-1) n(n+1)-1$ & \multirow[t]{2}{*}{$\mathrm{SQ}_{\mathrm{e}}$} & \multirow[t]{2}{*}{$M_{e^{\prime}}$} & \multirow{2}{*}{\multicolumn{2}{|c|}{$\sigma^{2}$}} & \\
\hline & $1 \quad 2$ & & & & & \\
\hline
\end{tabular}

tendo-se que:

$$
\begin{aligned}
& S Q_{g}=\frac{1}{n+2}\left[\sum_{i}\left(Y_{i \cdot}+Y_{i j}\right)^{2}-\frac{4}{n} Y^{2} \cdot\right] ; \\
& S Q_{S}=\sum_{i \leq j} Y_{i j}^{2}-\frac{1}{n+2} \Sigma_{i}\left(Y_{i .}+Y_{i j}\right)^{2}+\frac{2}{(n+1)(n+2)} Y_{*}^{2} ; \\
& M_{e^{r}}=\frac{Q M_{4}}{b}, Q_{4} \text { é o quadxado médio da interação } \\
& \text { grupos x blocos (Tabela 2); }
\end{aligned}
$$

sendo:

$$
\begin{aligned}
Y_{i=}= & \sum_{j} Y_{i j}=Y_{i 1}+Y_{i 3}+\ldots+Y_{i n} \\
Y_{0 .}= & \sum_{i<j} Y_{i j}=Y_{11}+Y_{12}+\ldots+Y_{22}+Y_{23}+\ldots+ \\
& +Y_{n 1}+Y_{n 2}+\ldots+Y_{n n}
\end{aligned}
$$




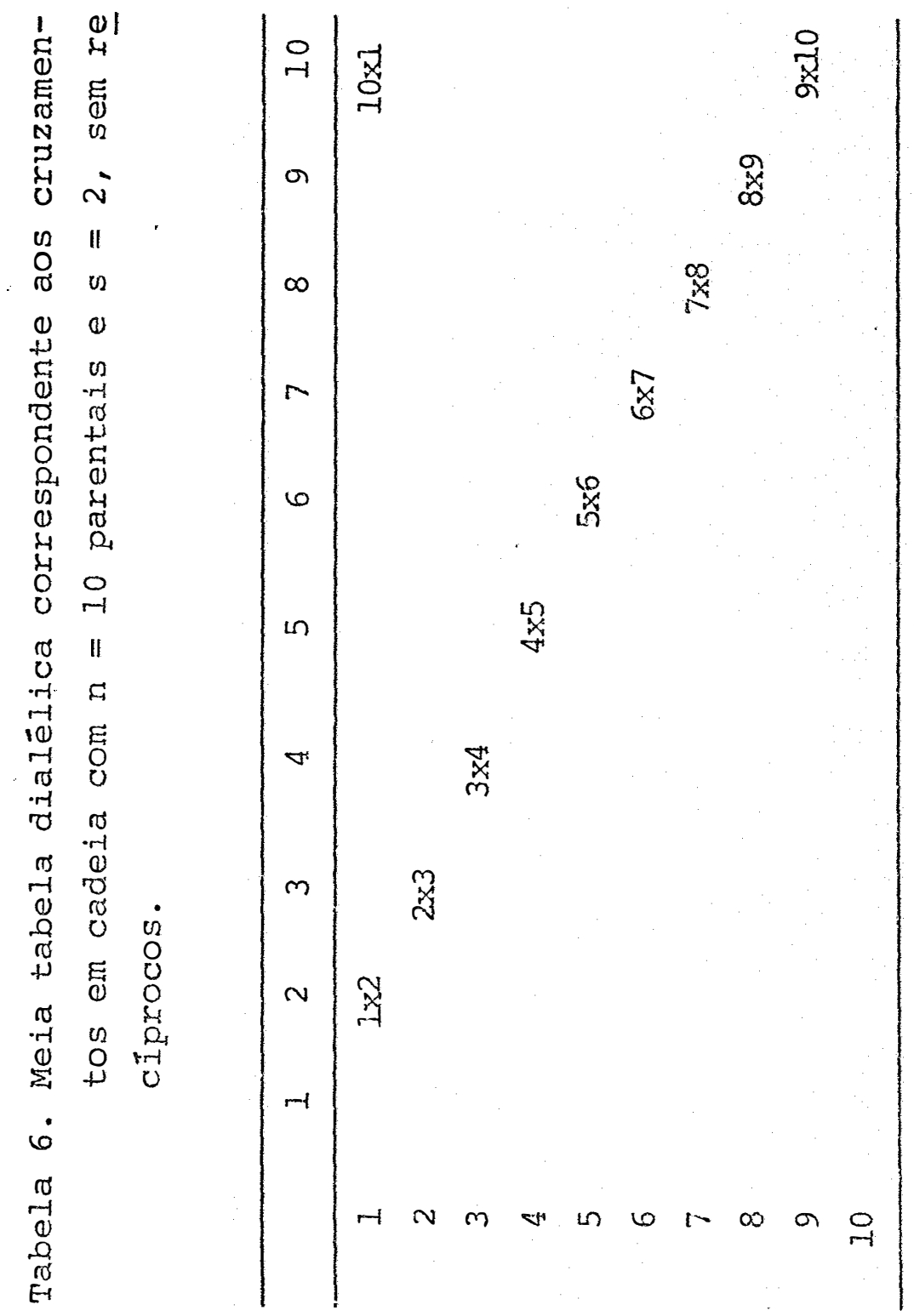




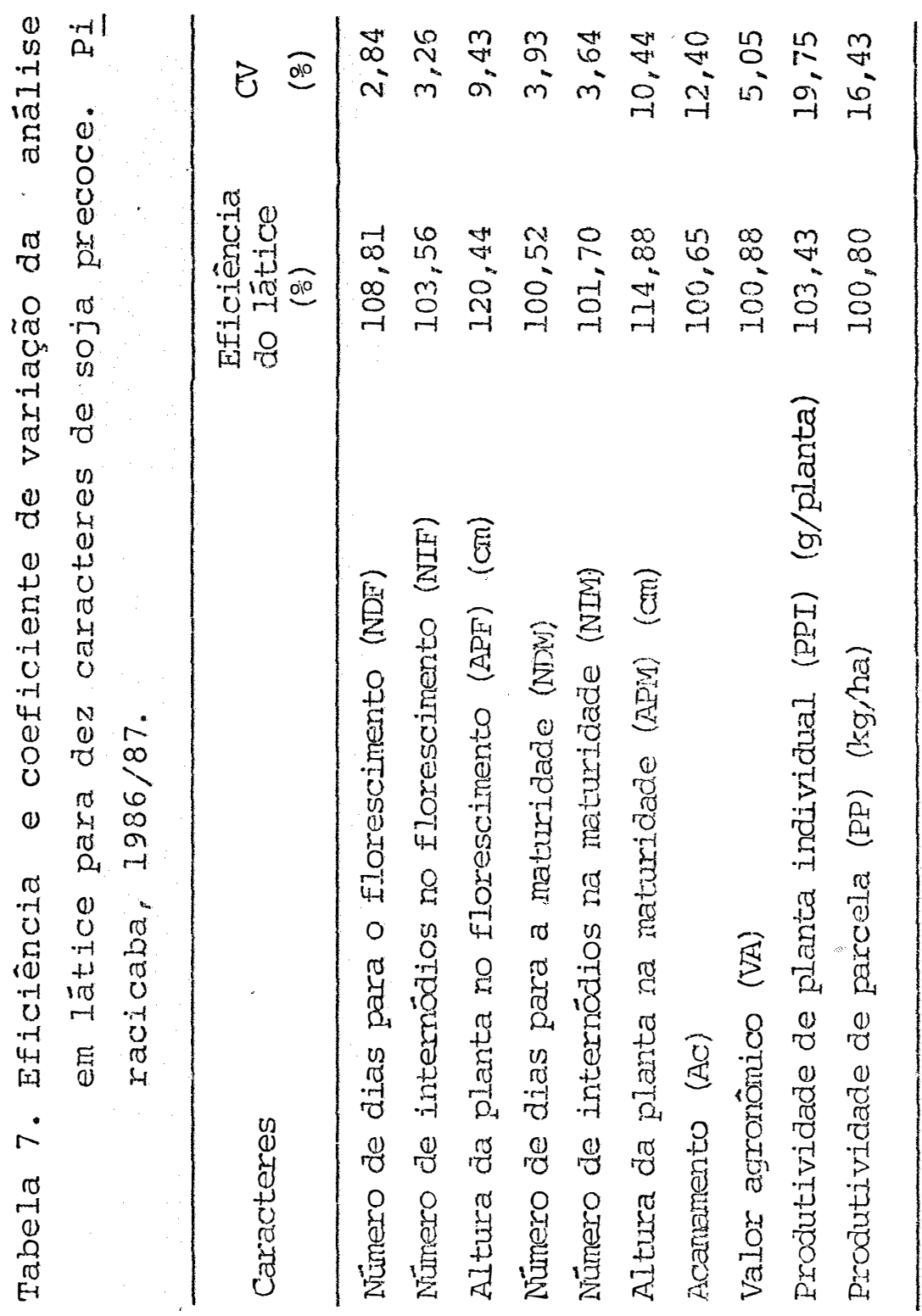




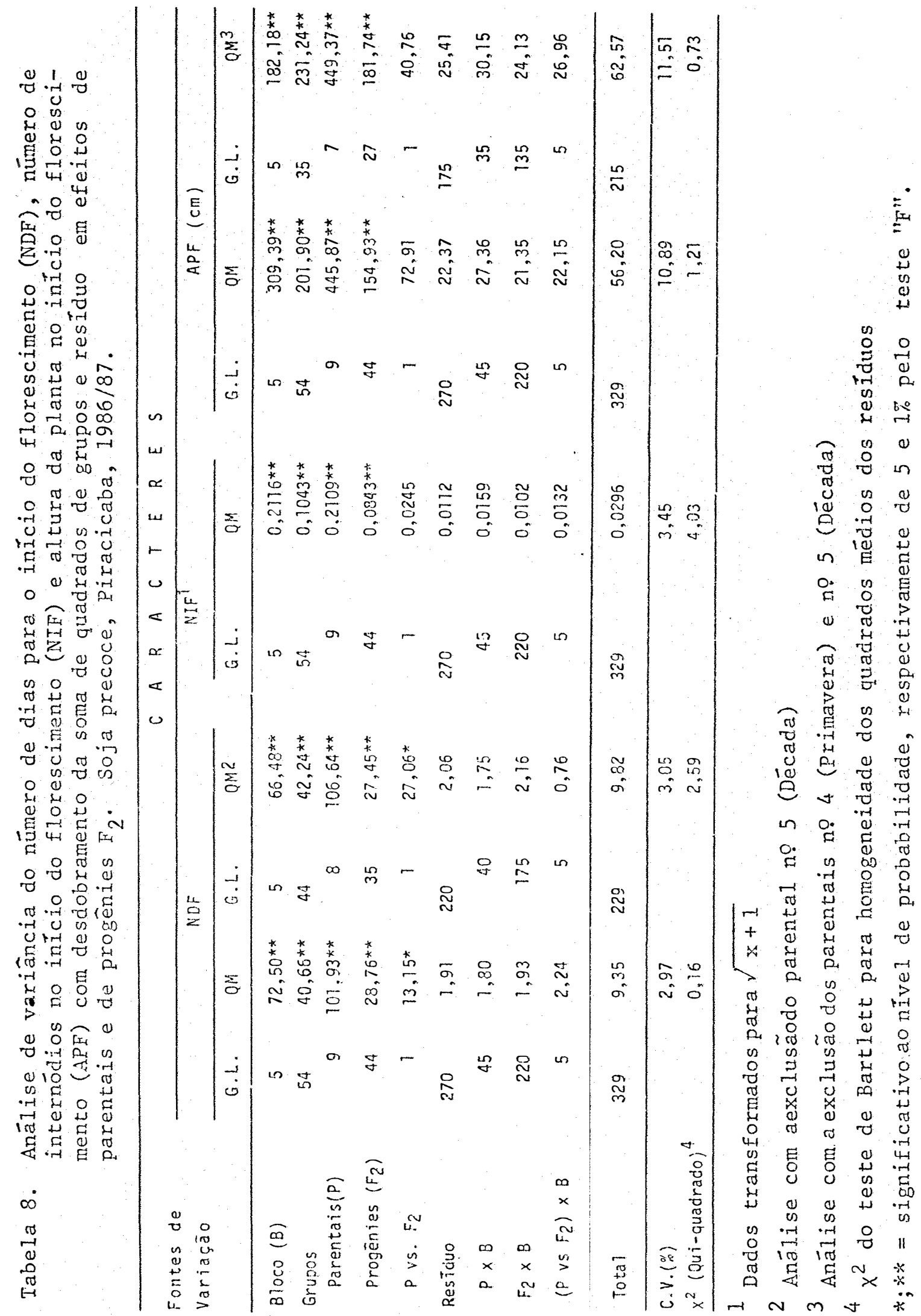




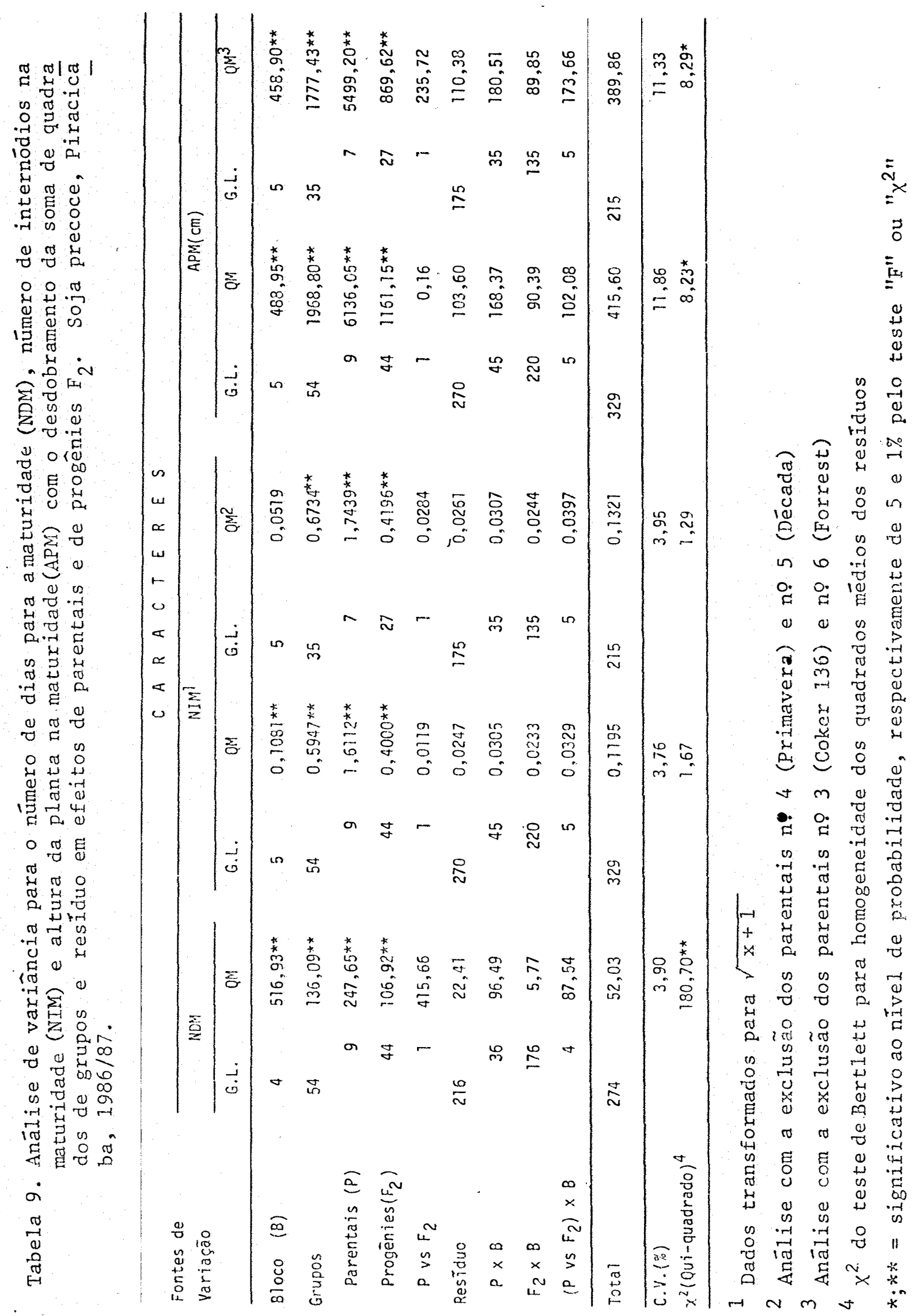




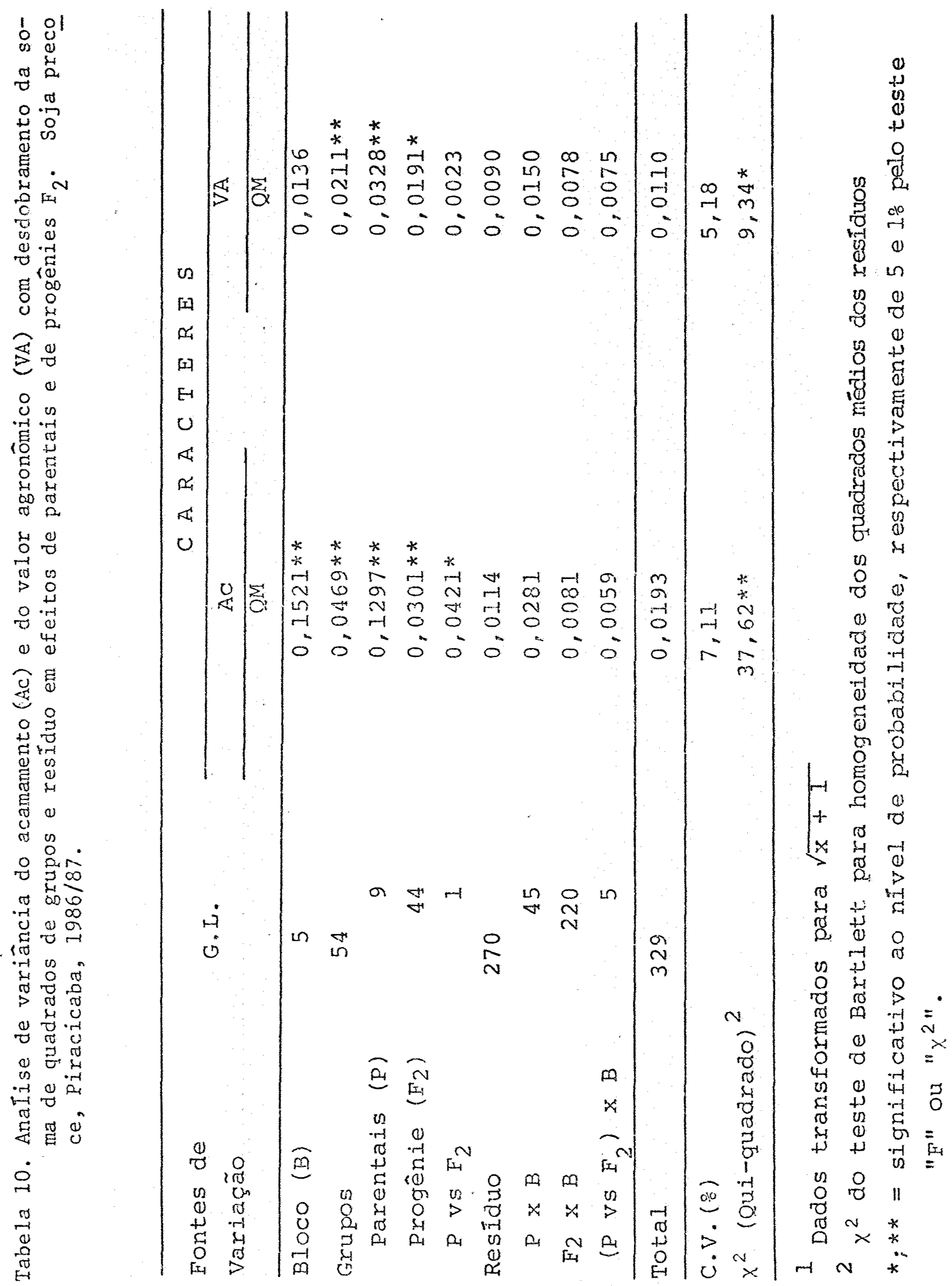




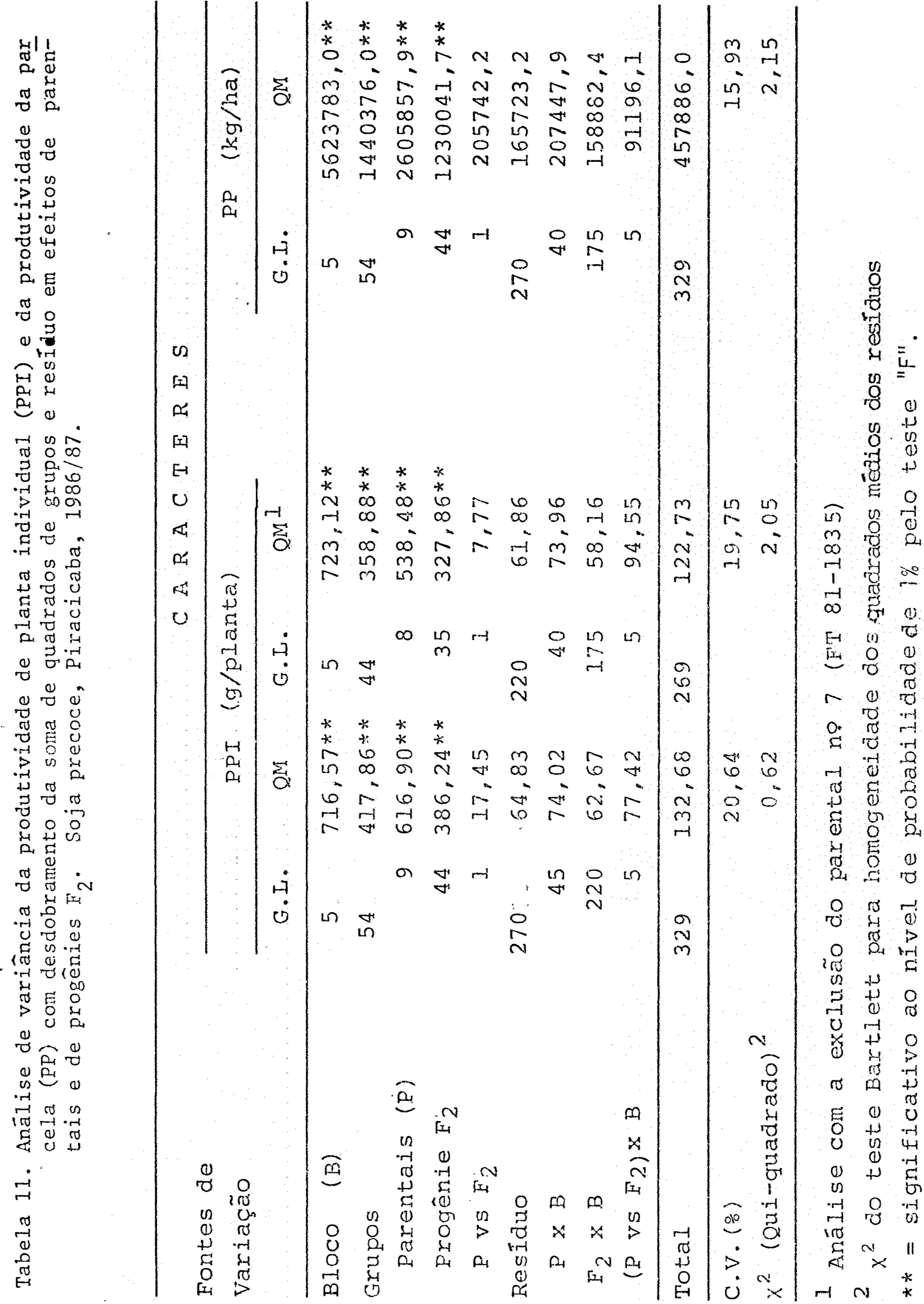




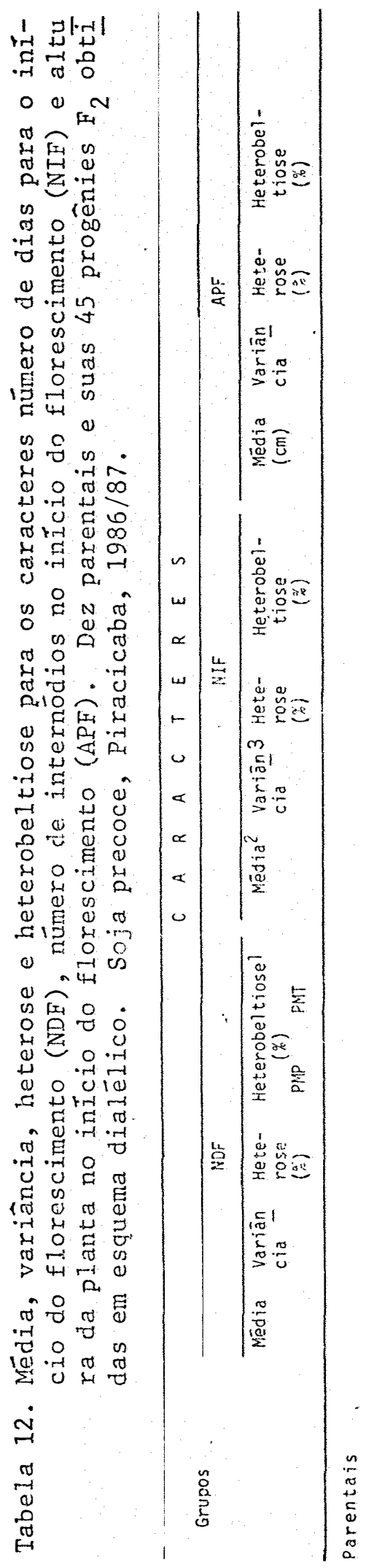

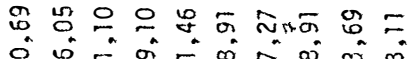
in in

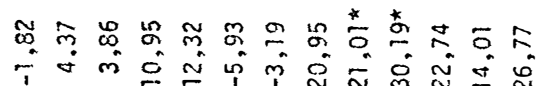
$\infty$ 유

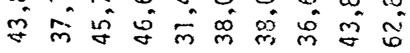

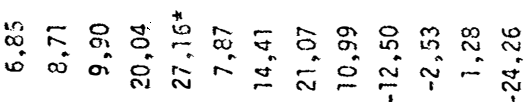

:

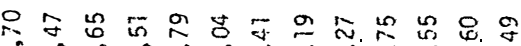

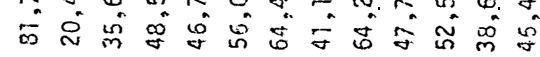

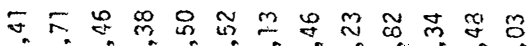

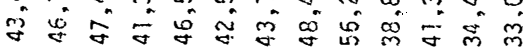

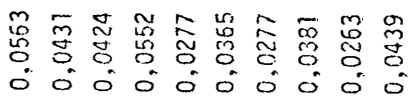
ๆ

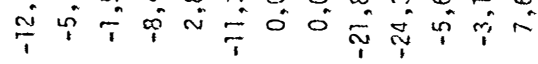

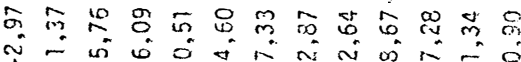

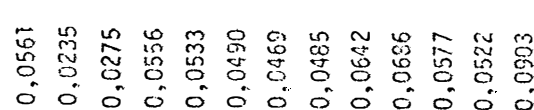

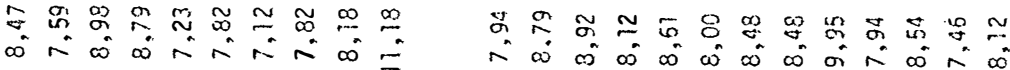

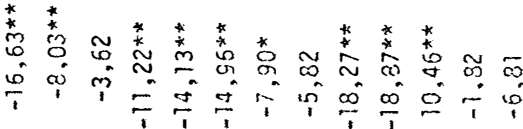

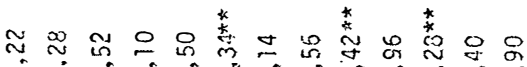

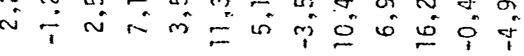
* i

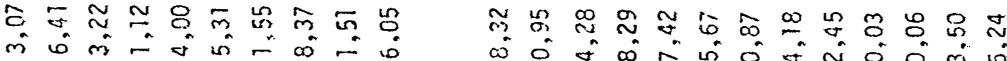

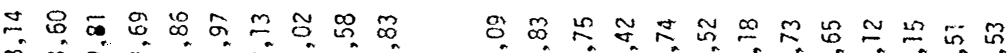

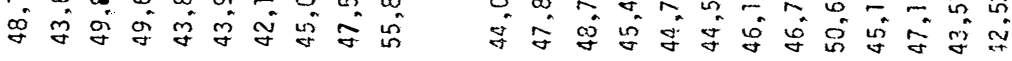

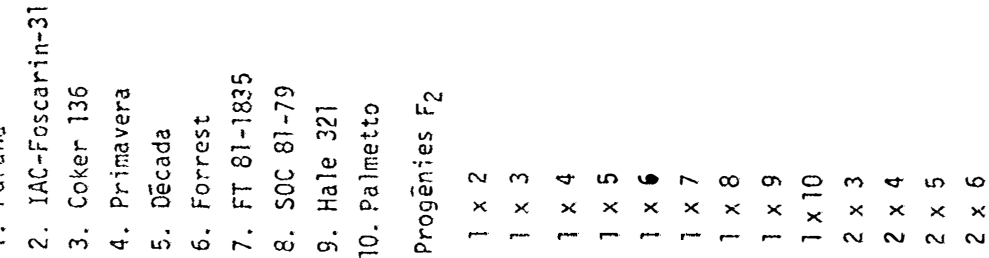




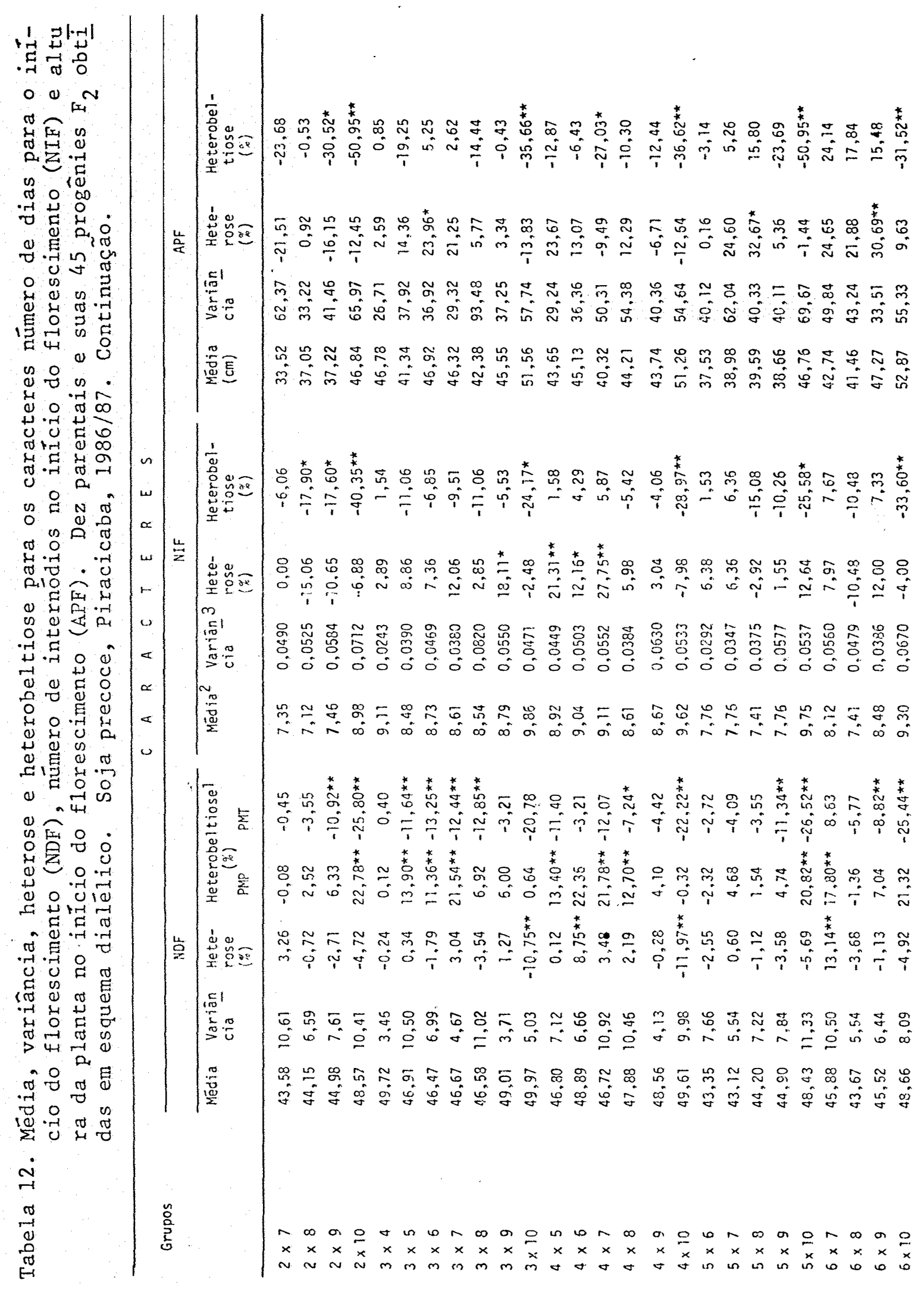




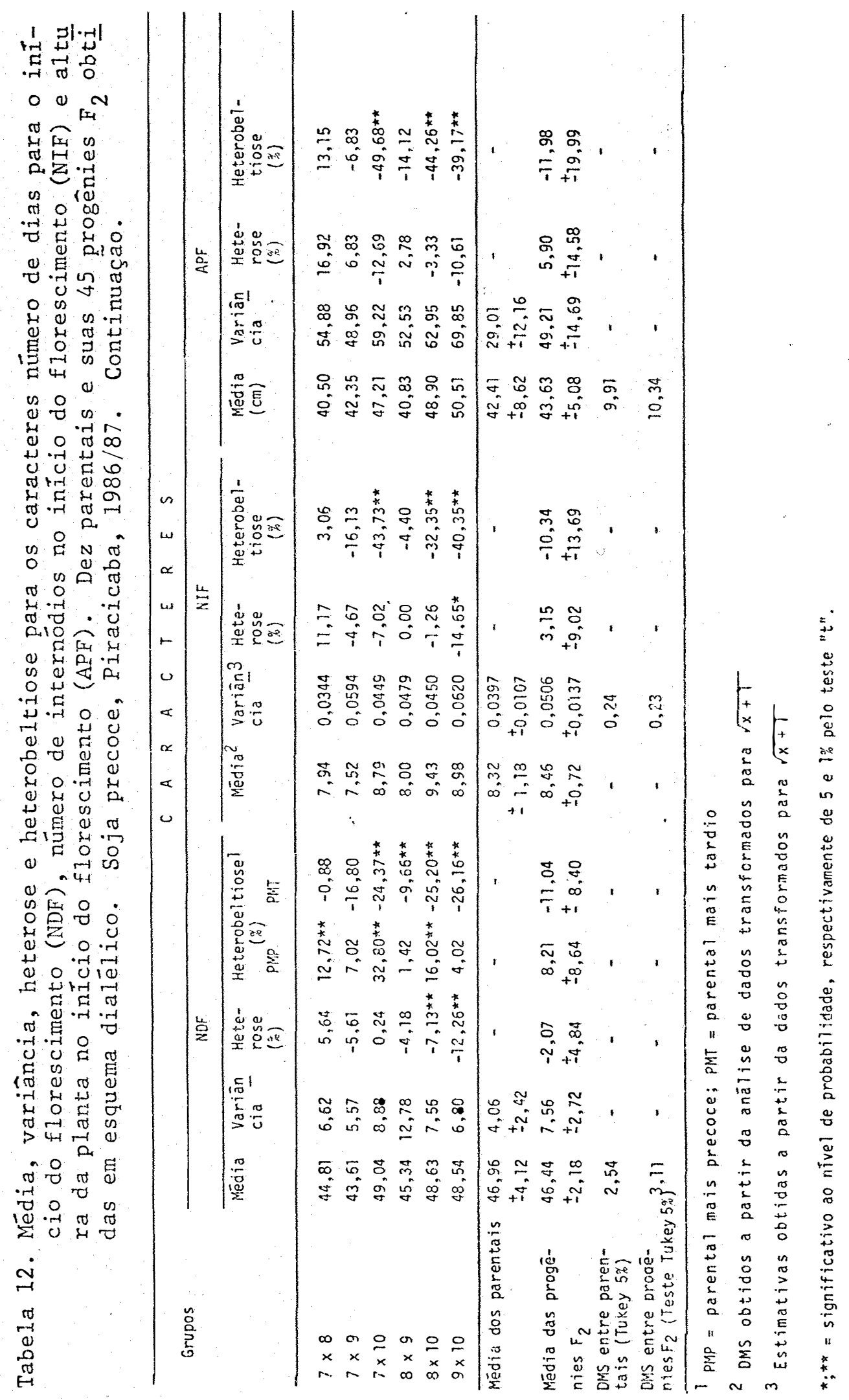




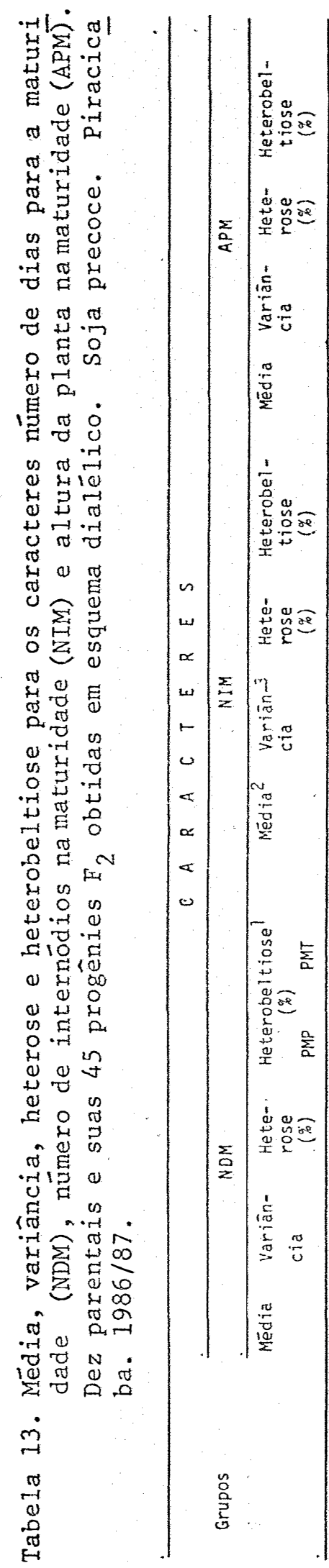

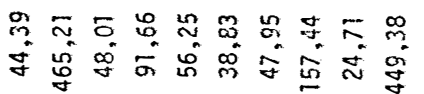

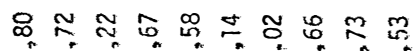

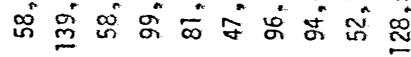

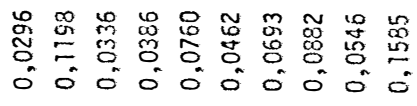

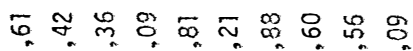

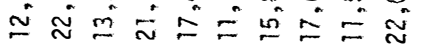

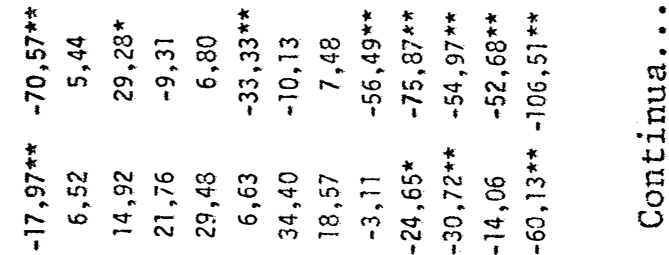

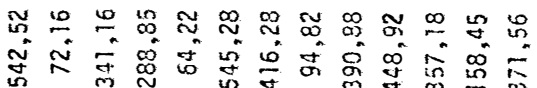

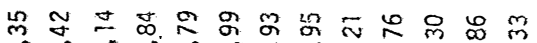
ลं

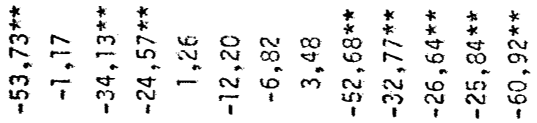

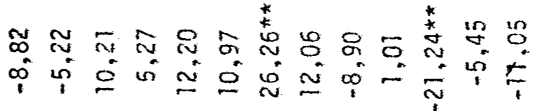

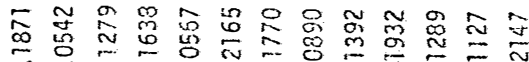

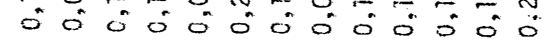

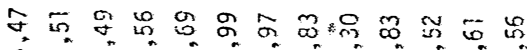
ஸ்

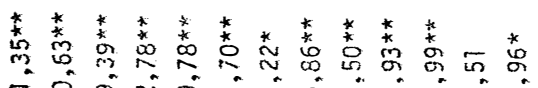

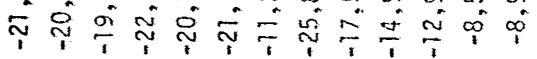
* *

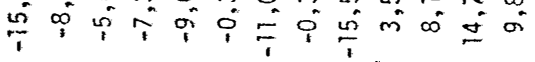

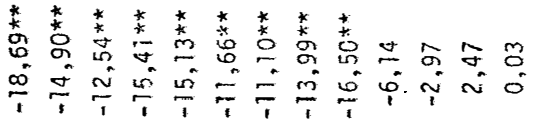

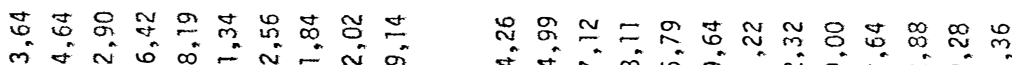
लंखें

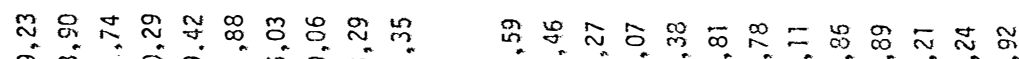

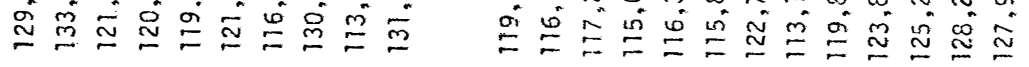

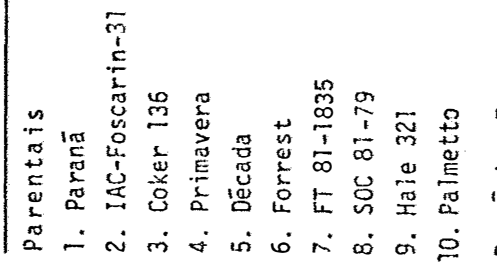




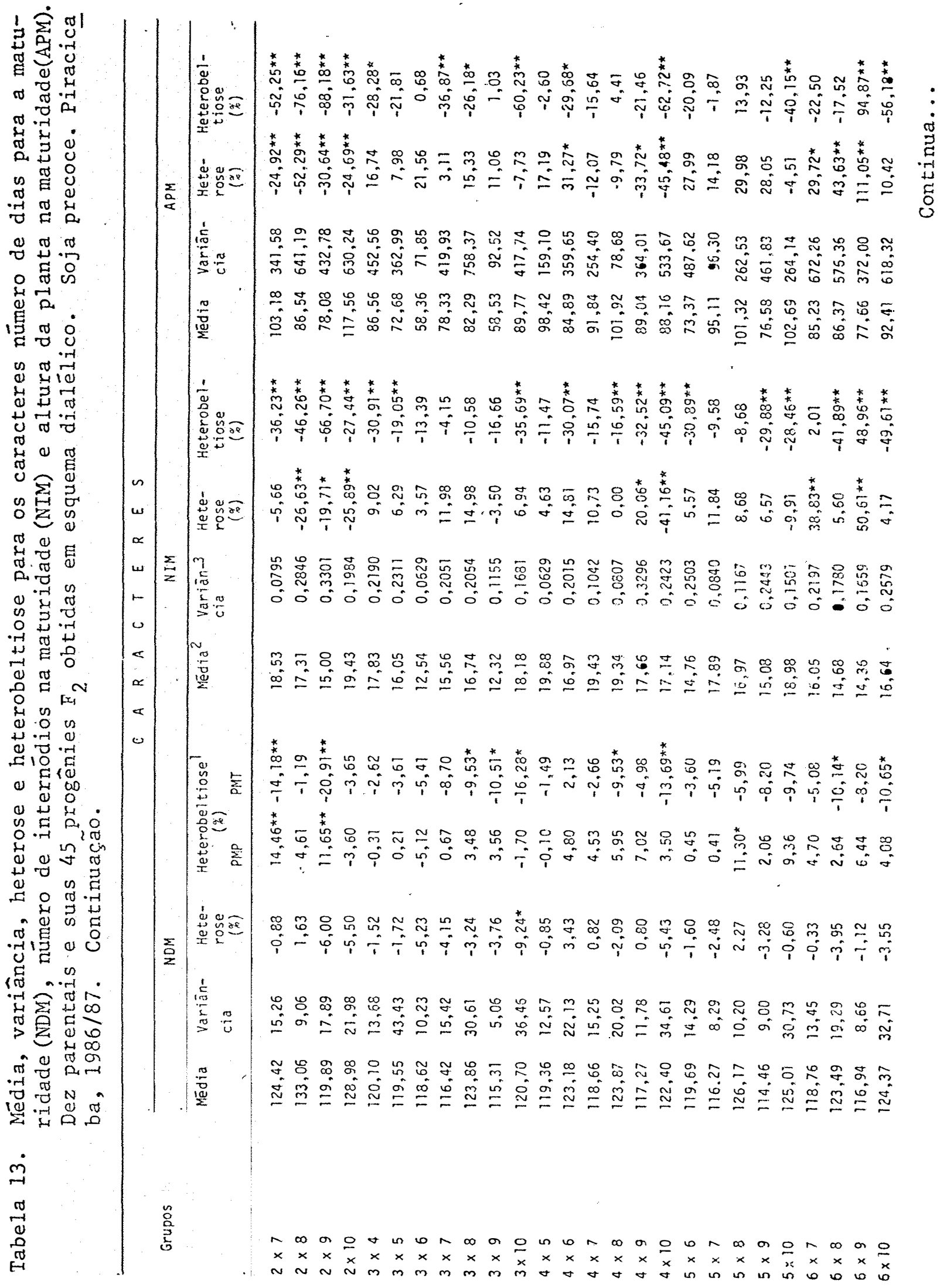




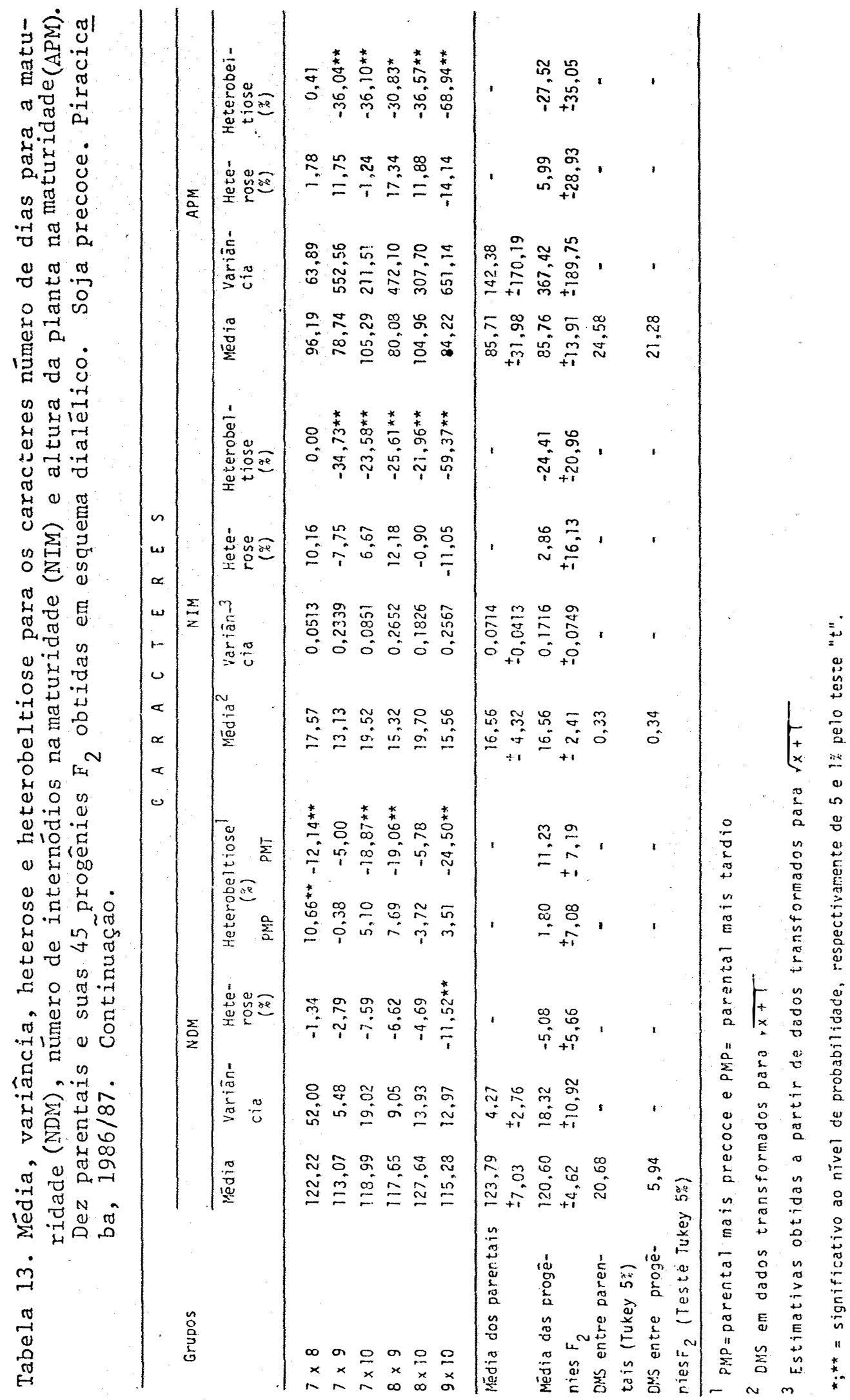




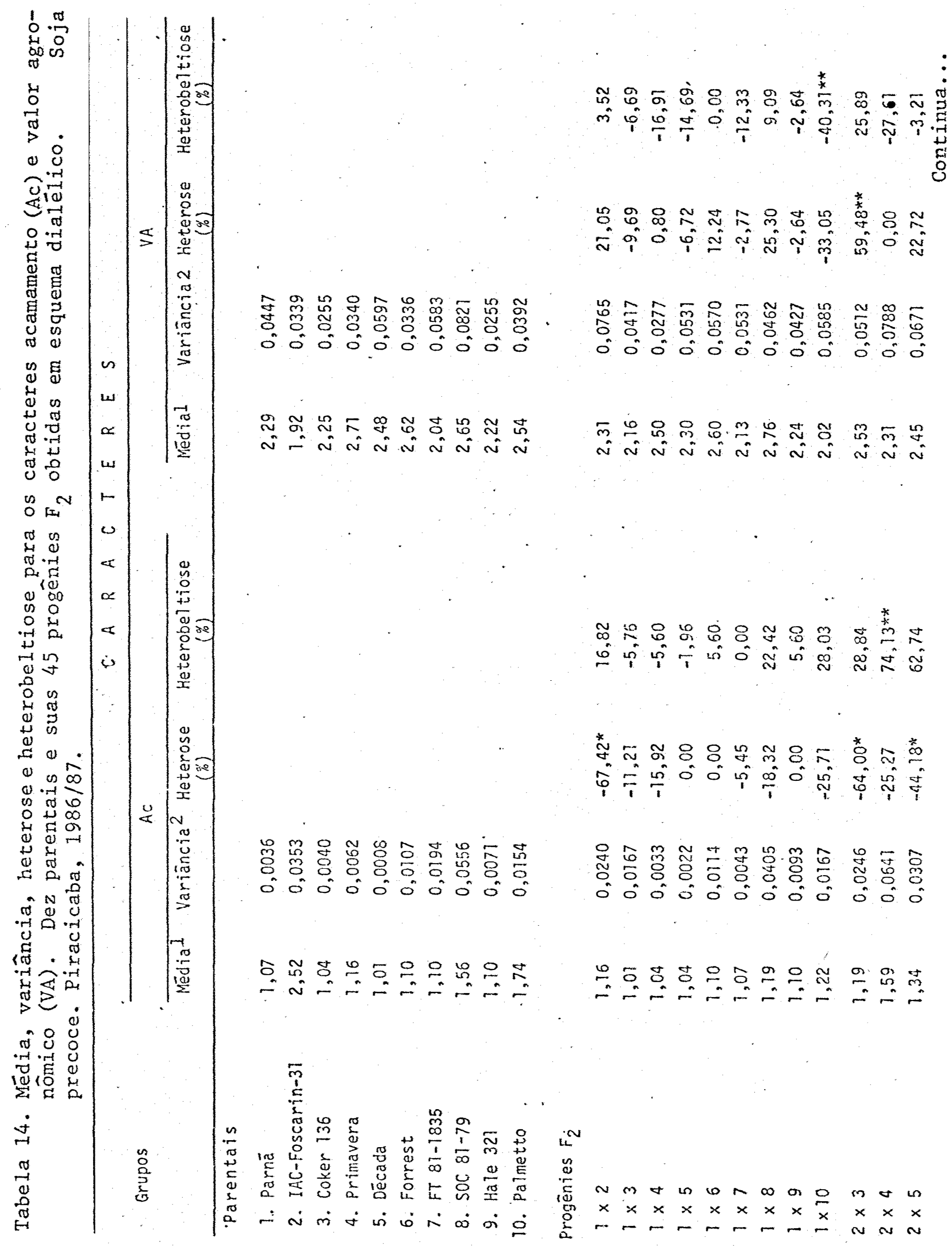




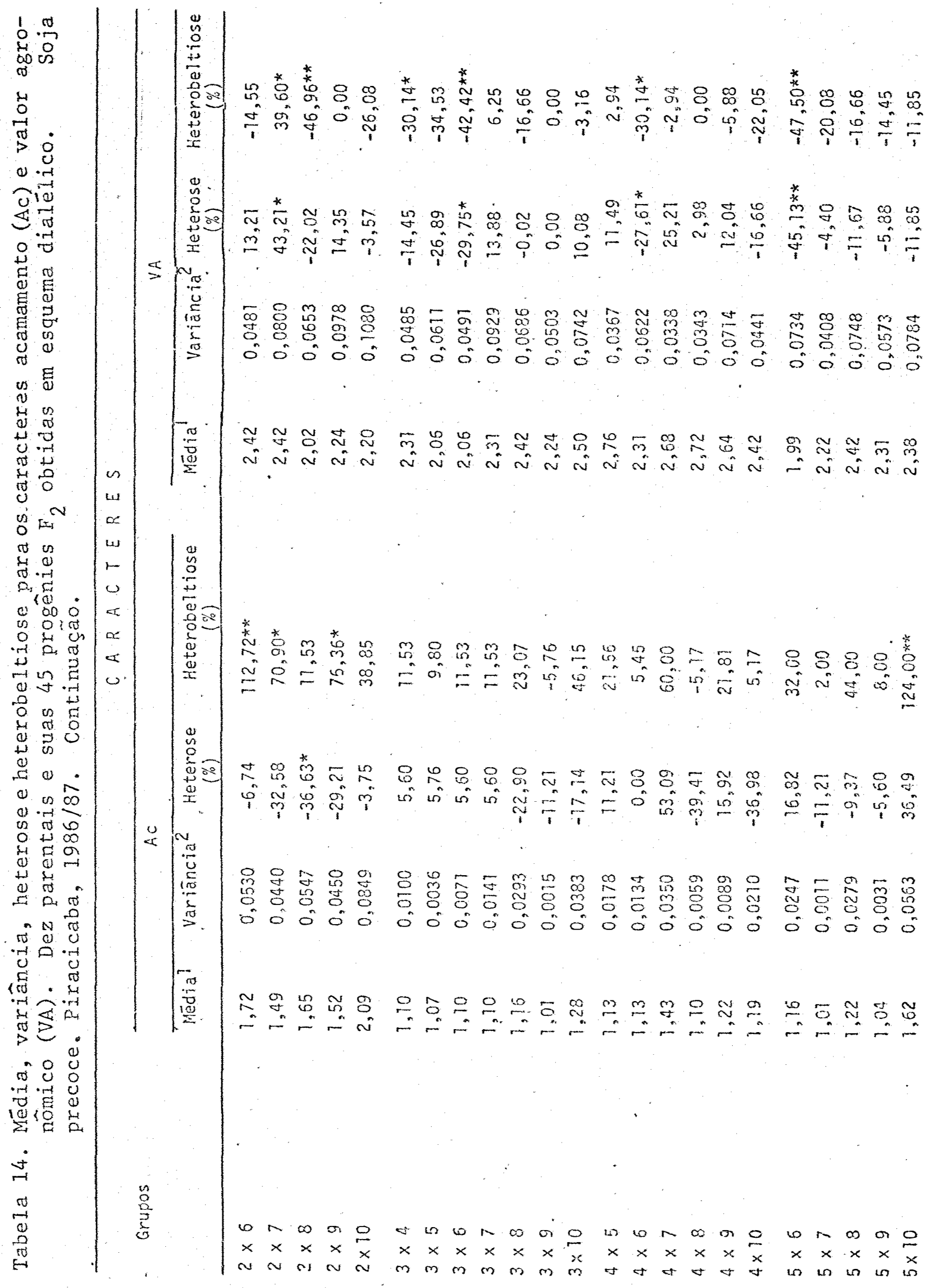




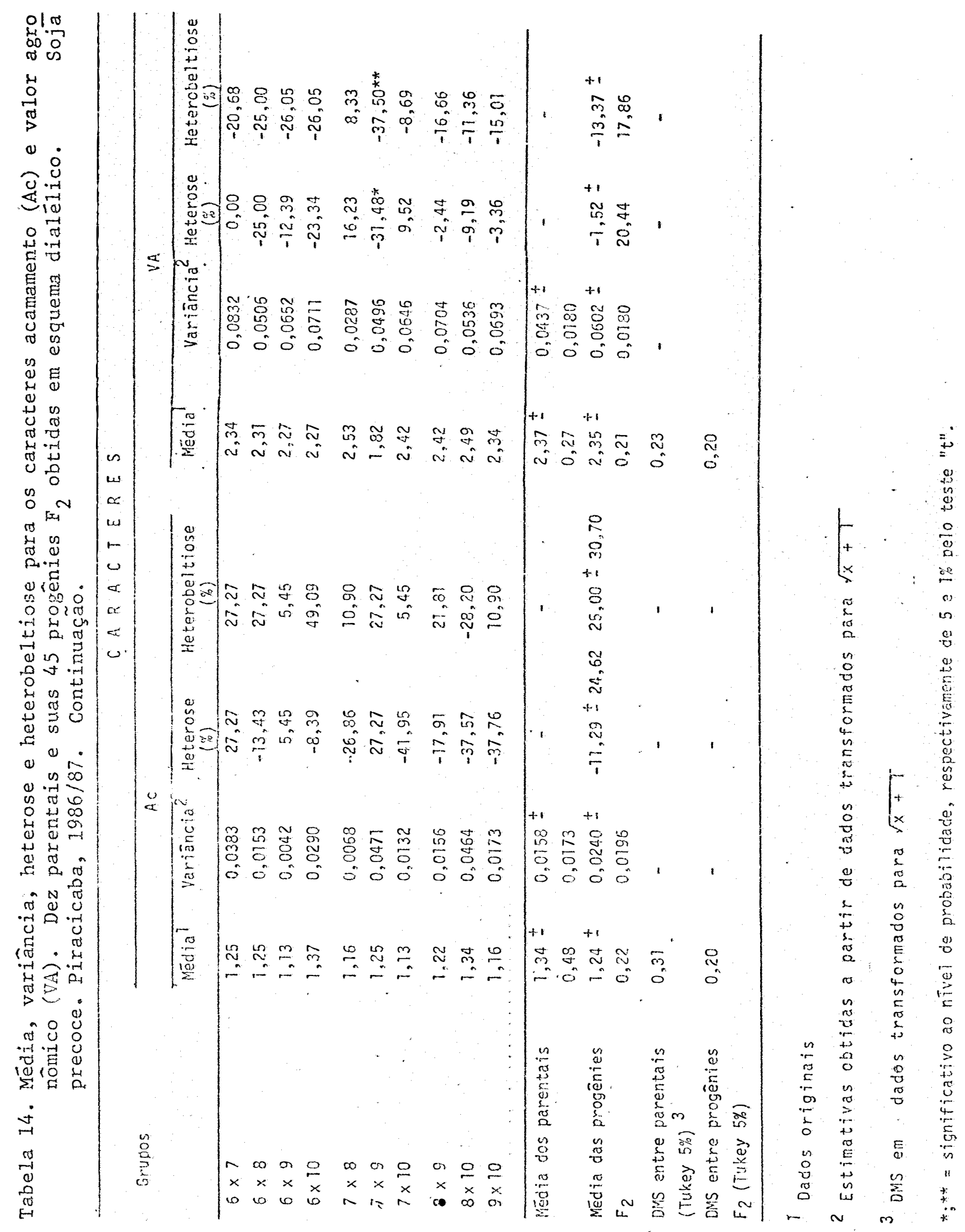




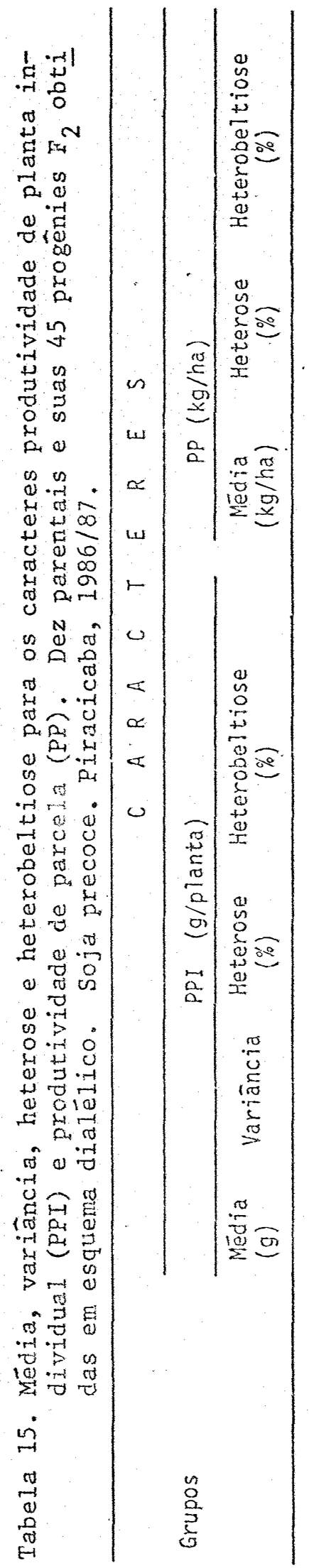

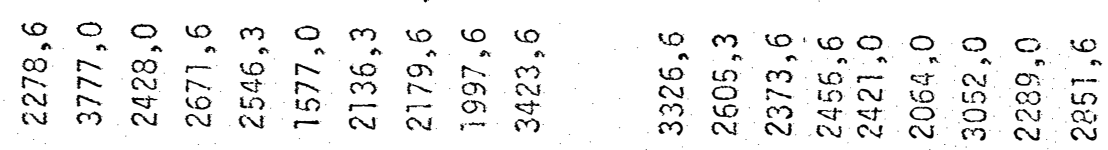

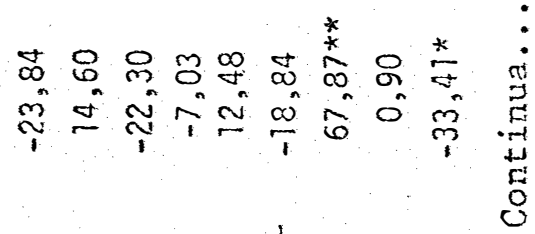

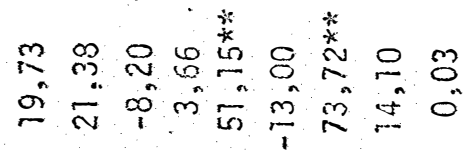

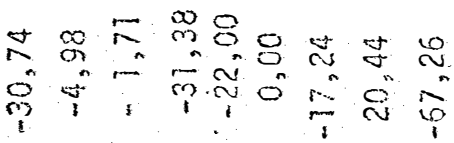

《i 吕

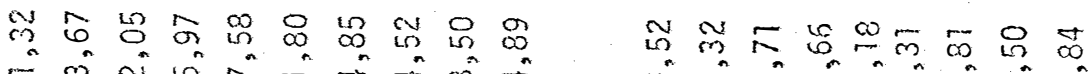

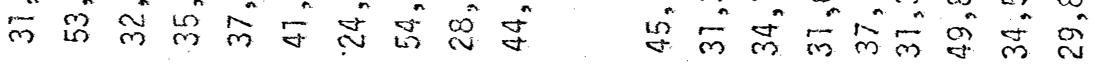

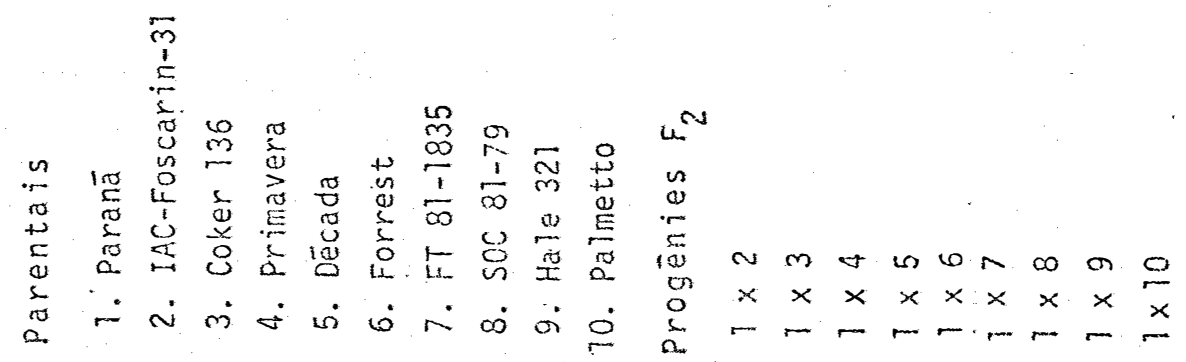

$+\stackrel{m}{m} g m g \circ g$

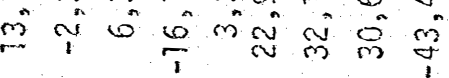




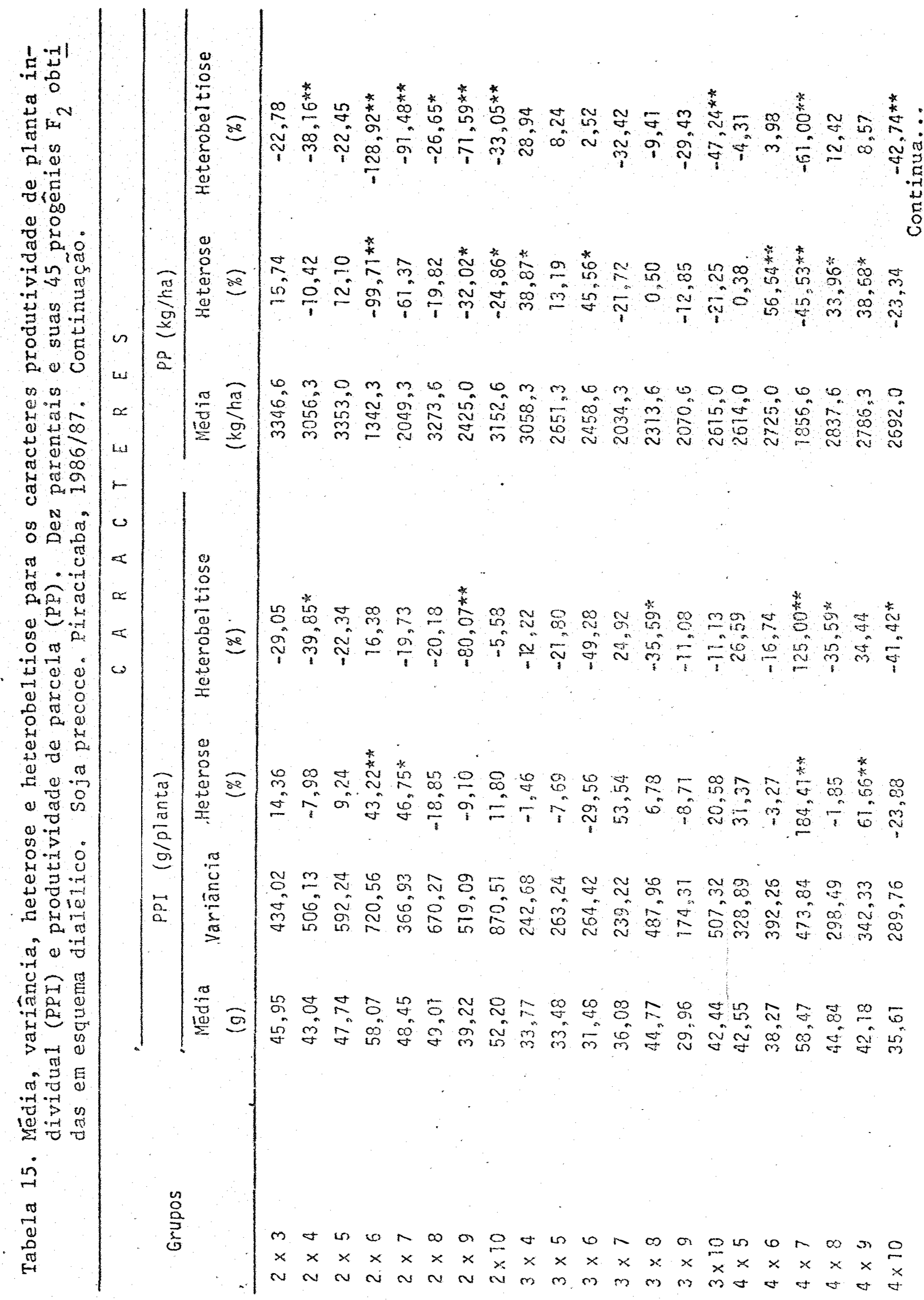


201.

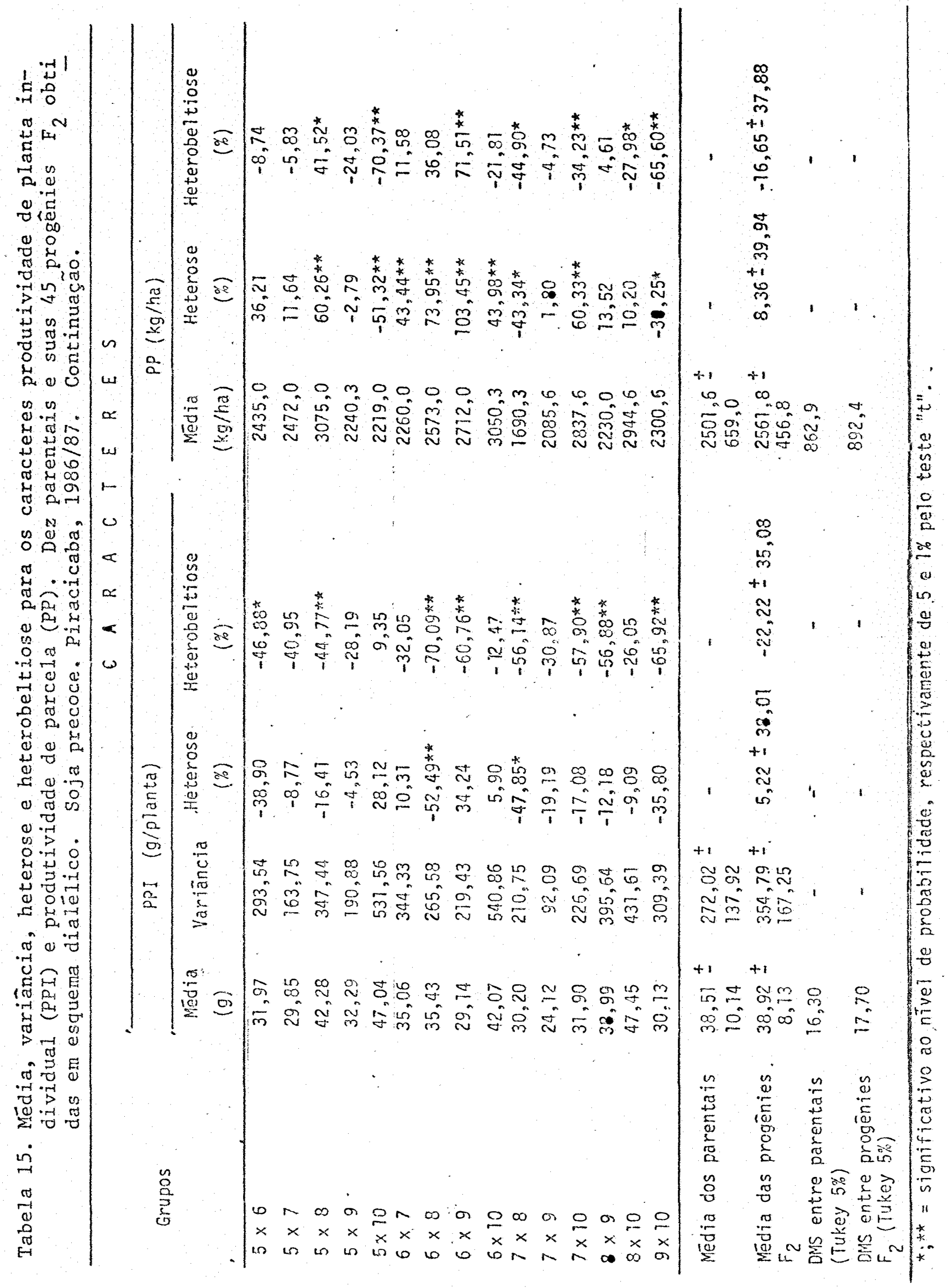




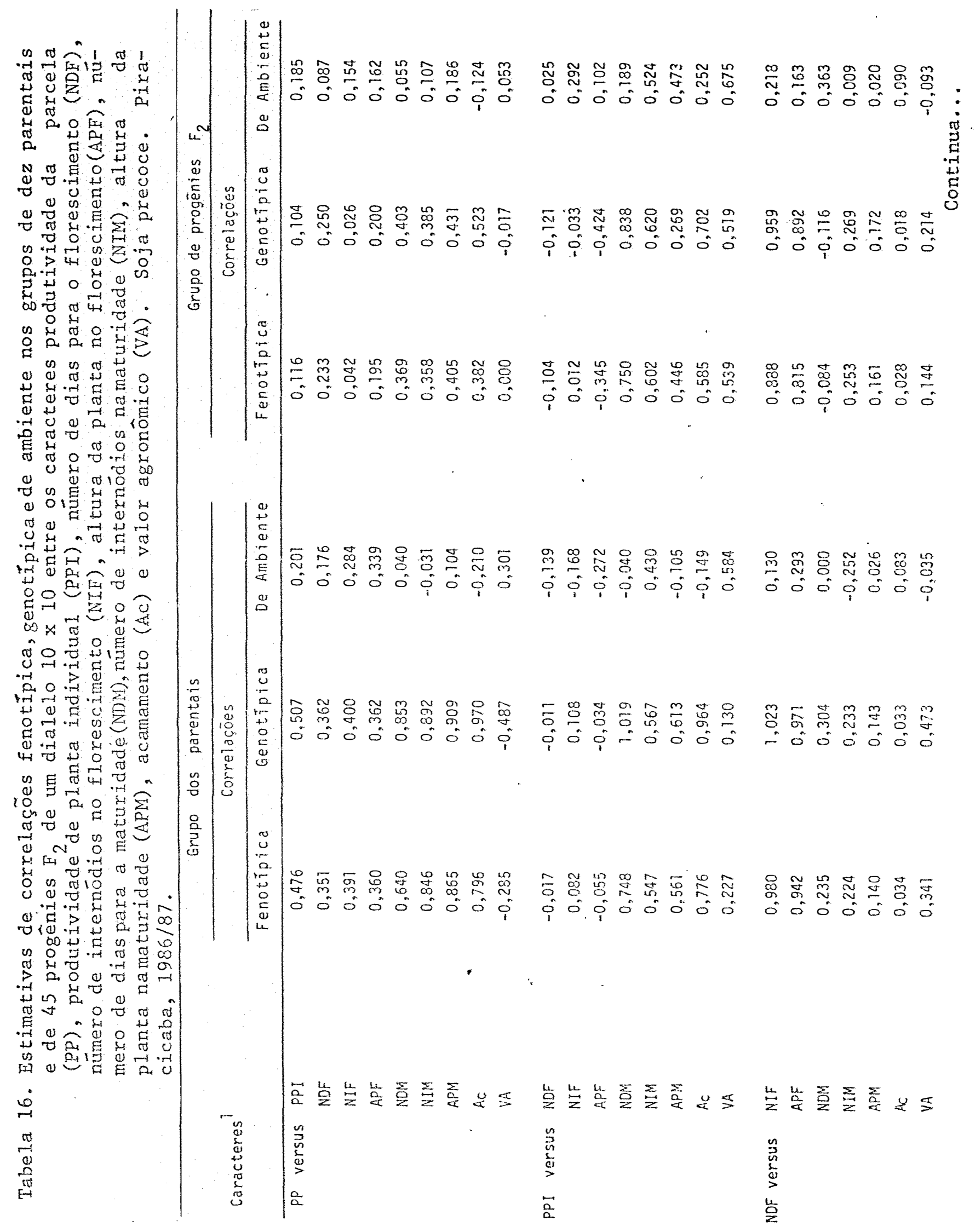




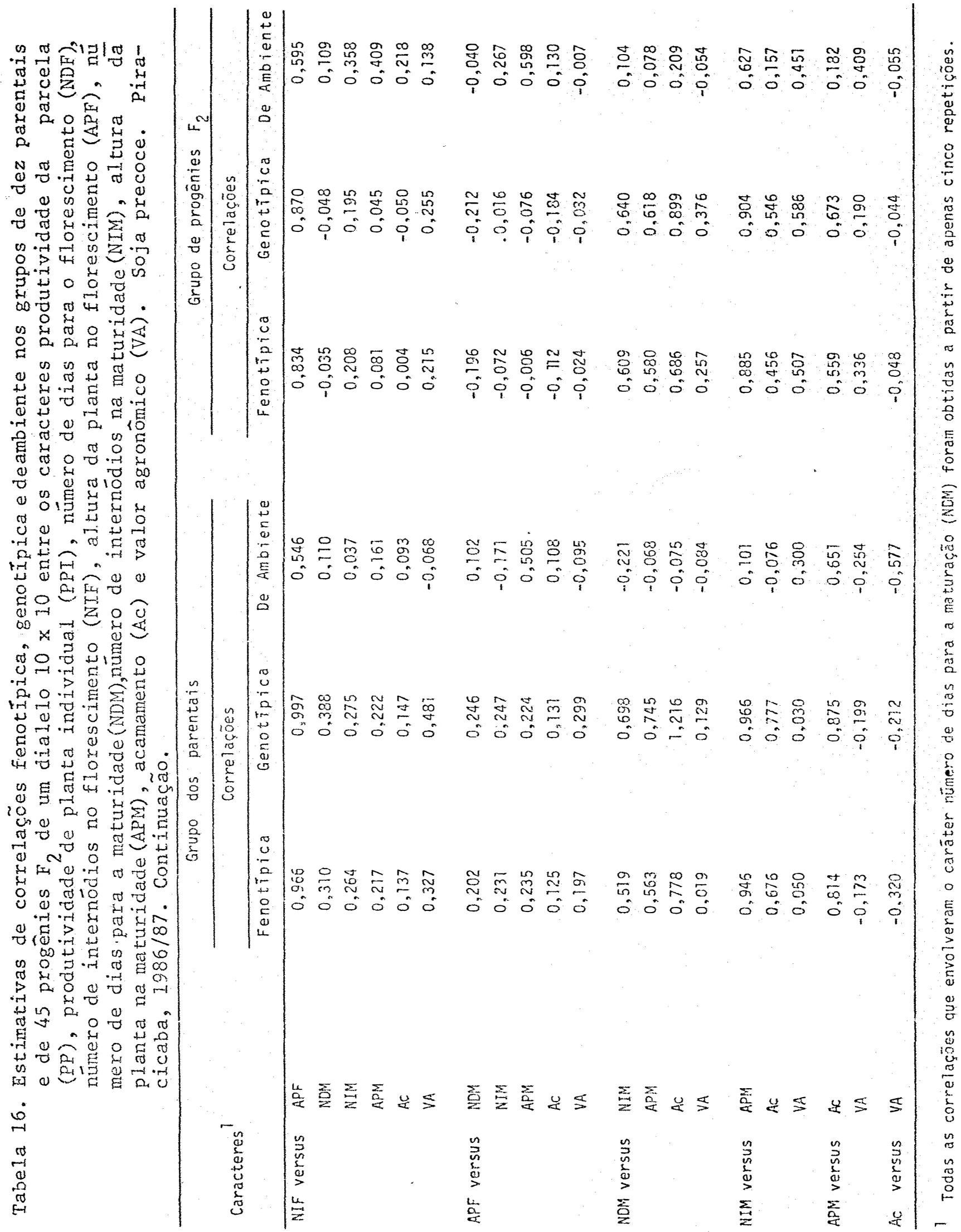




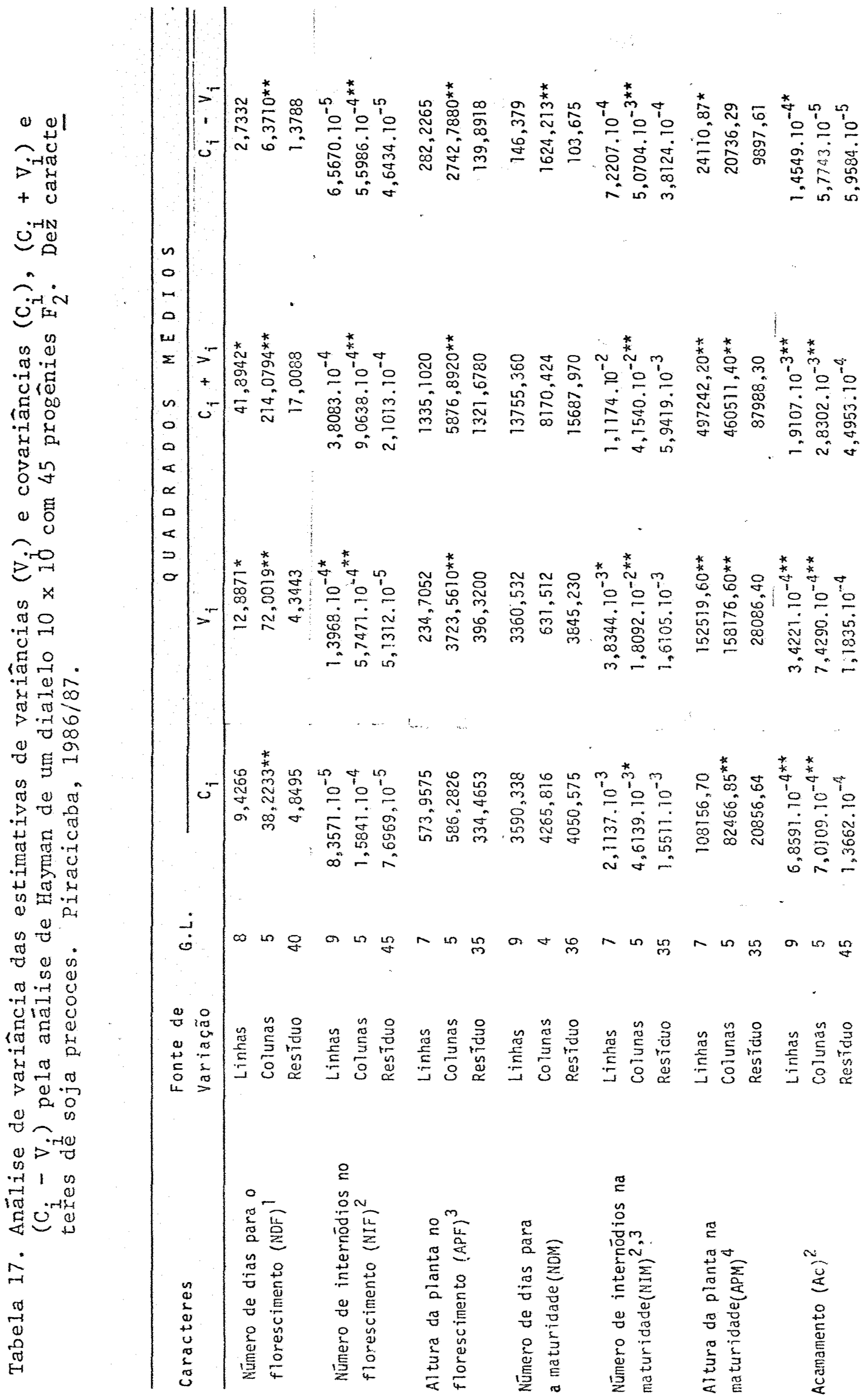




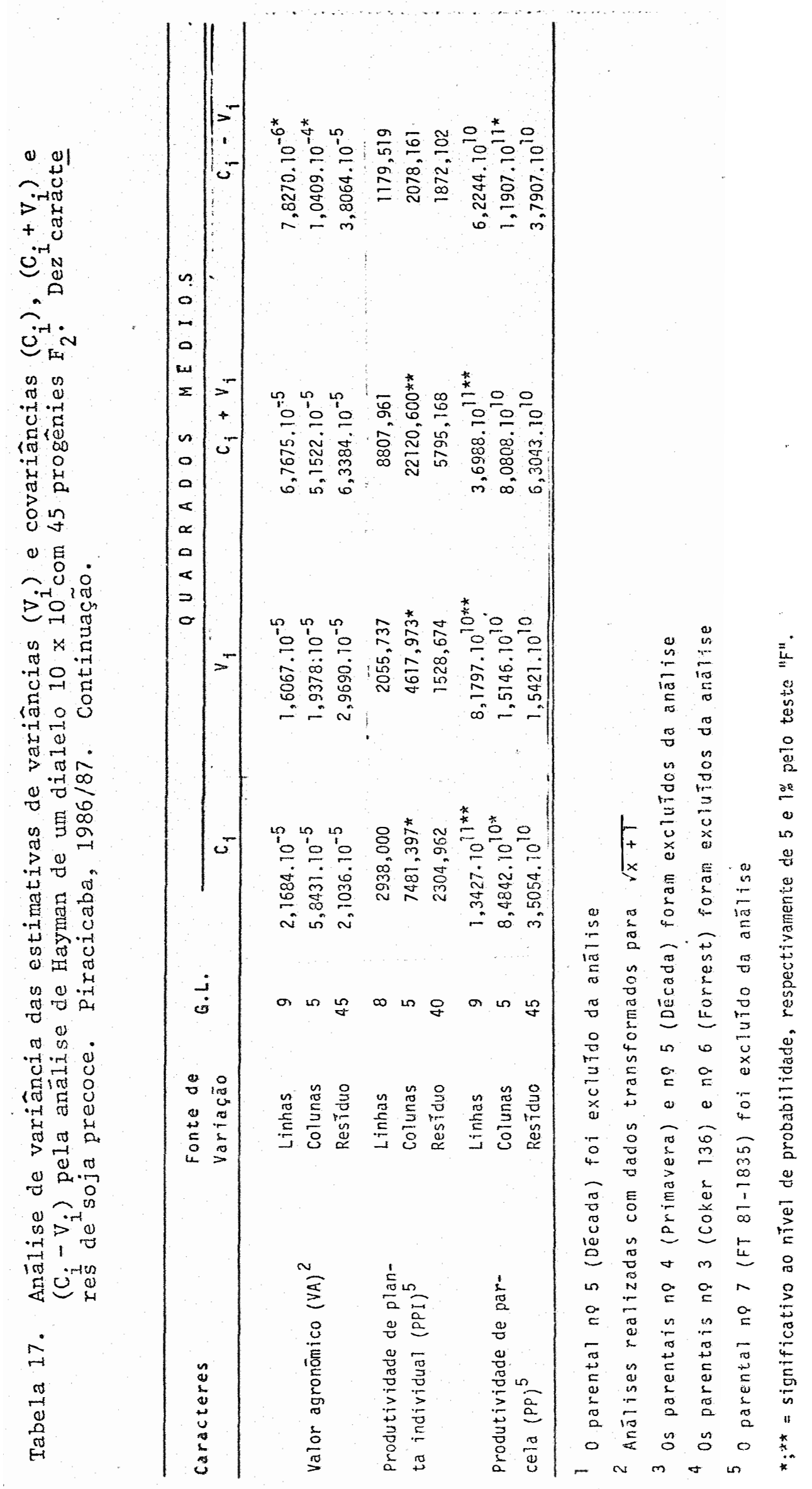




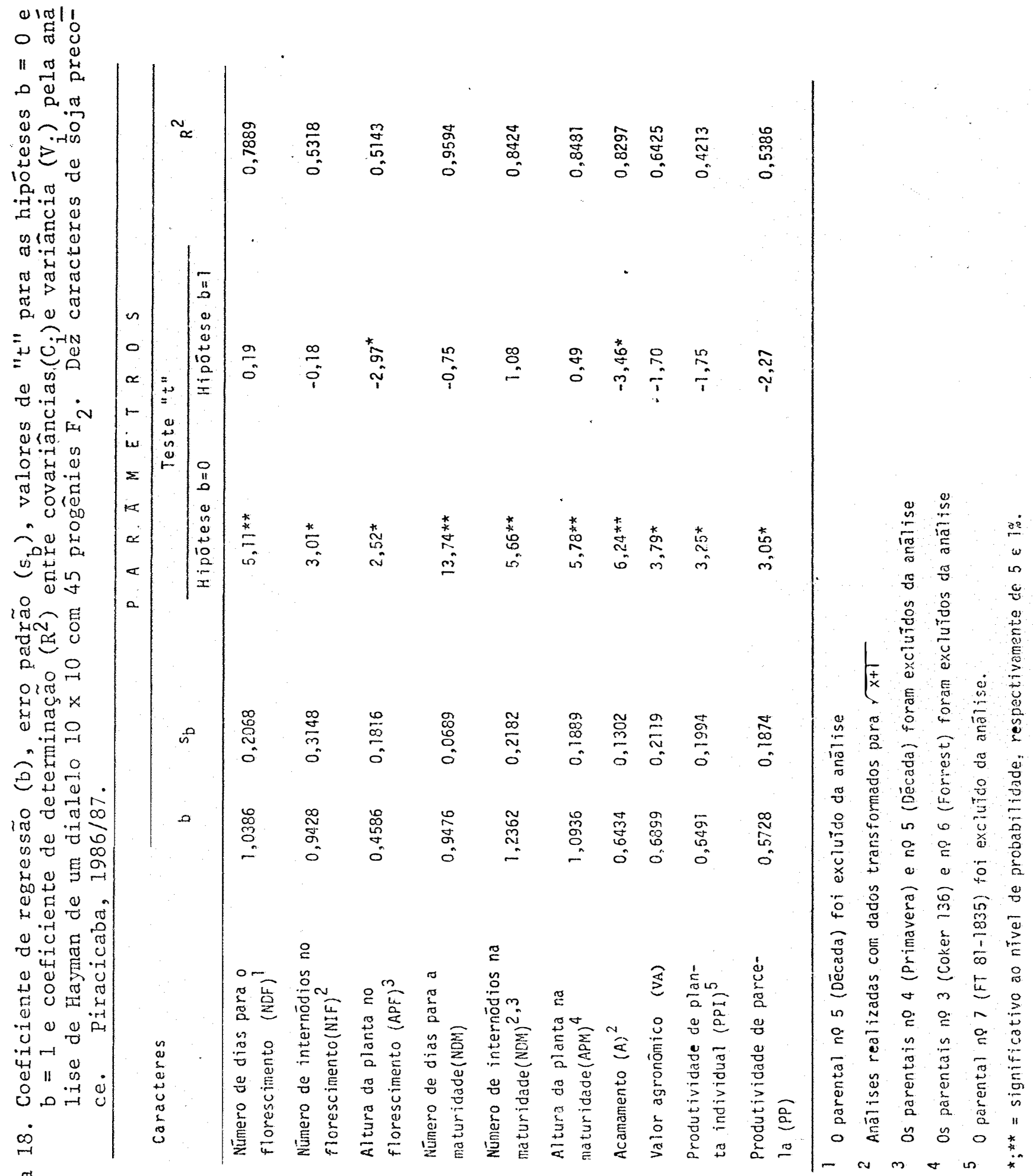




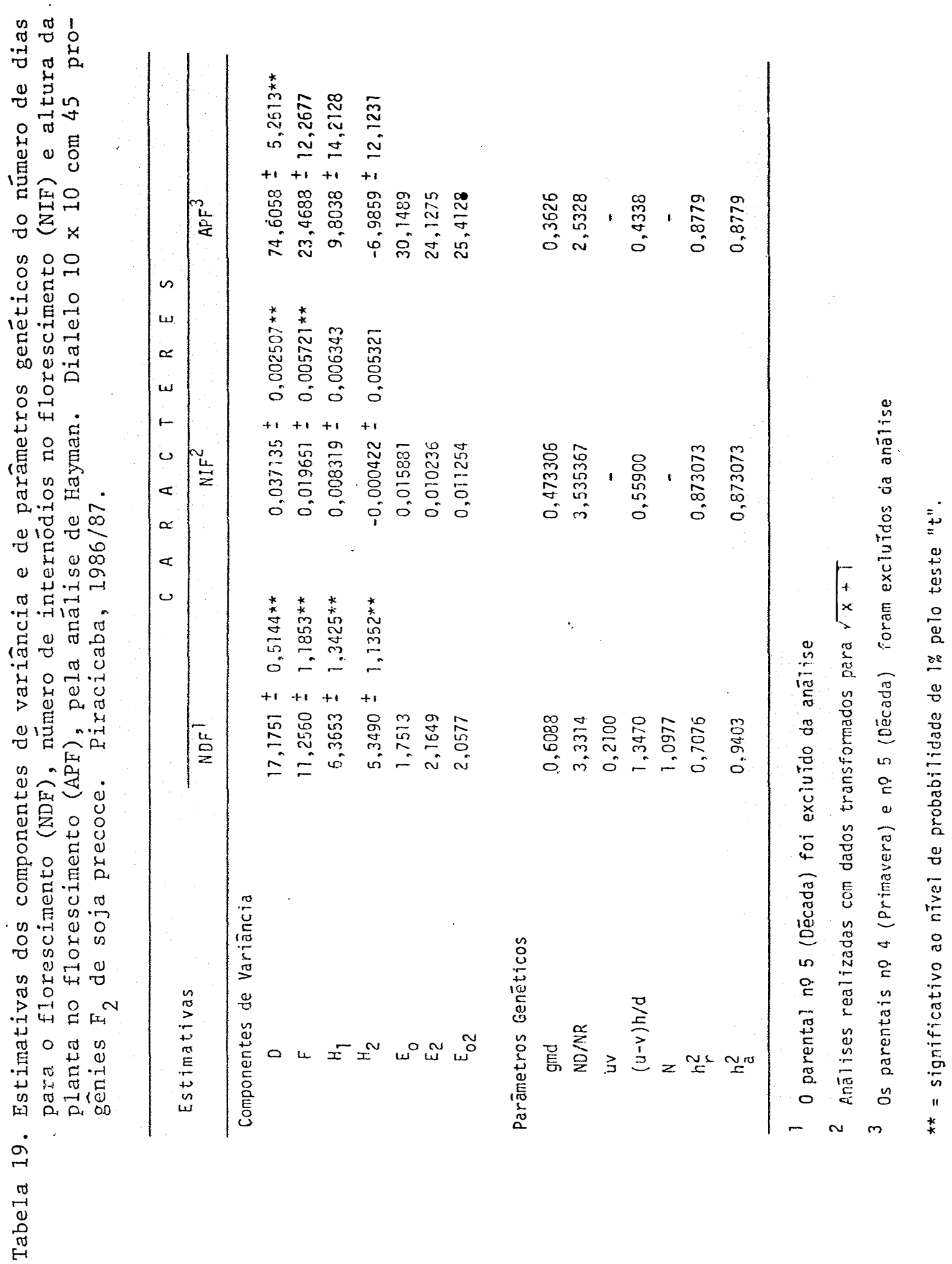




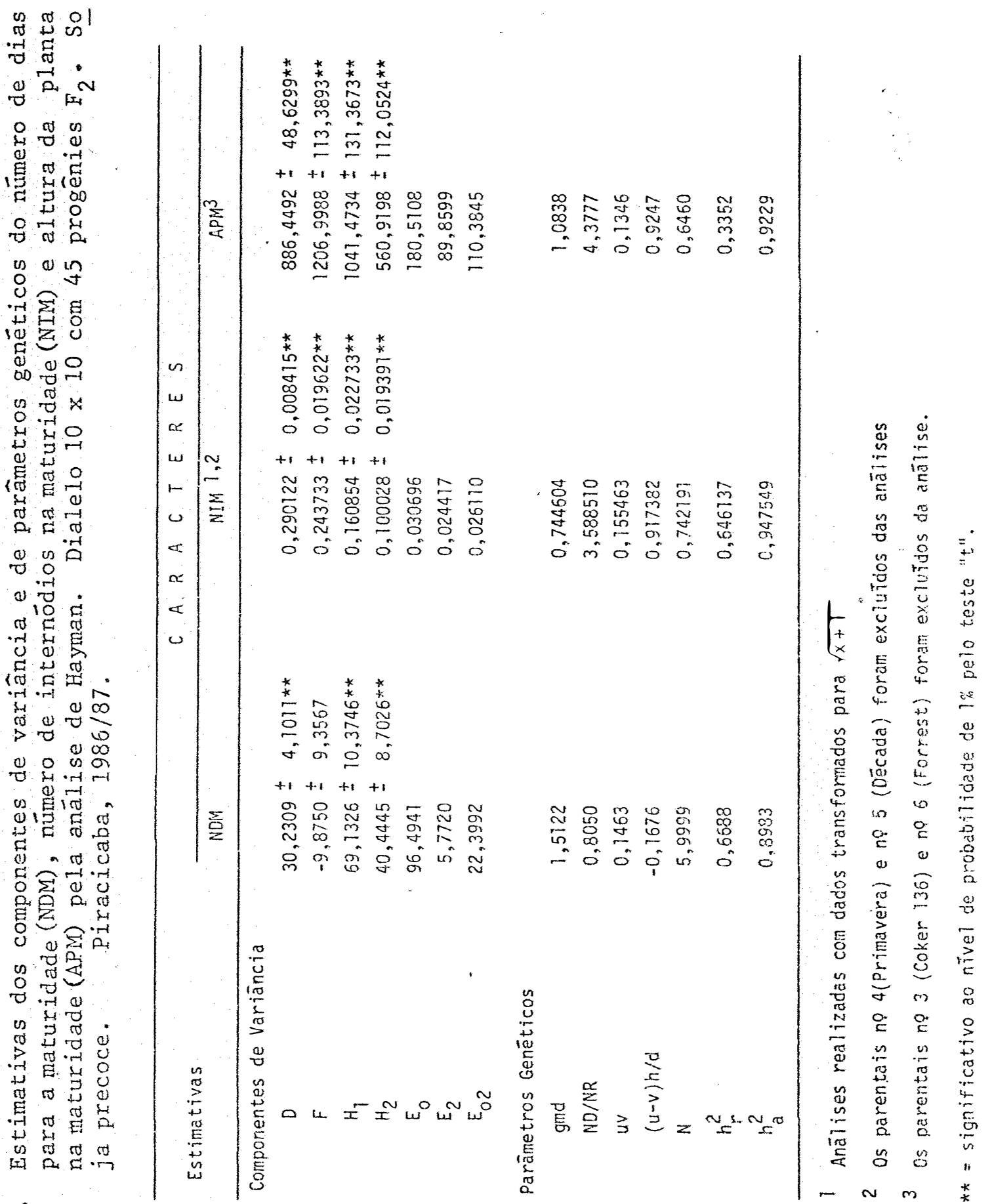

$\stackrel{0}{\circ}$

$\underbrace{0}_{0}$ 


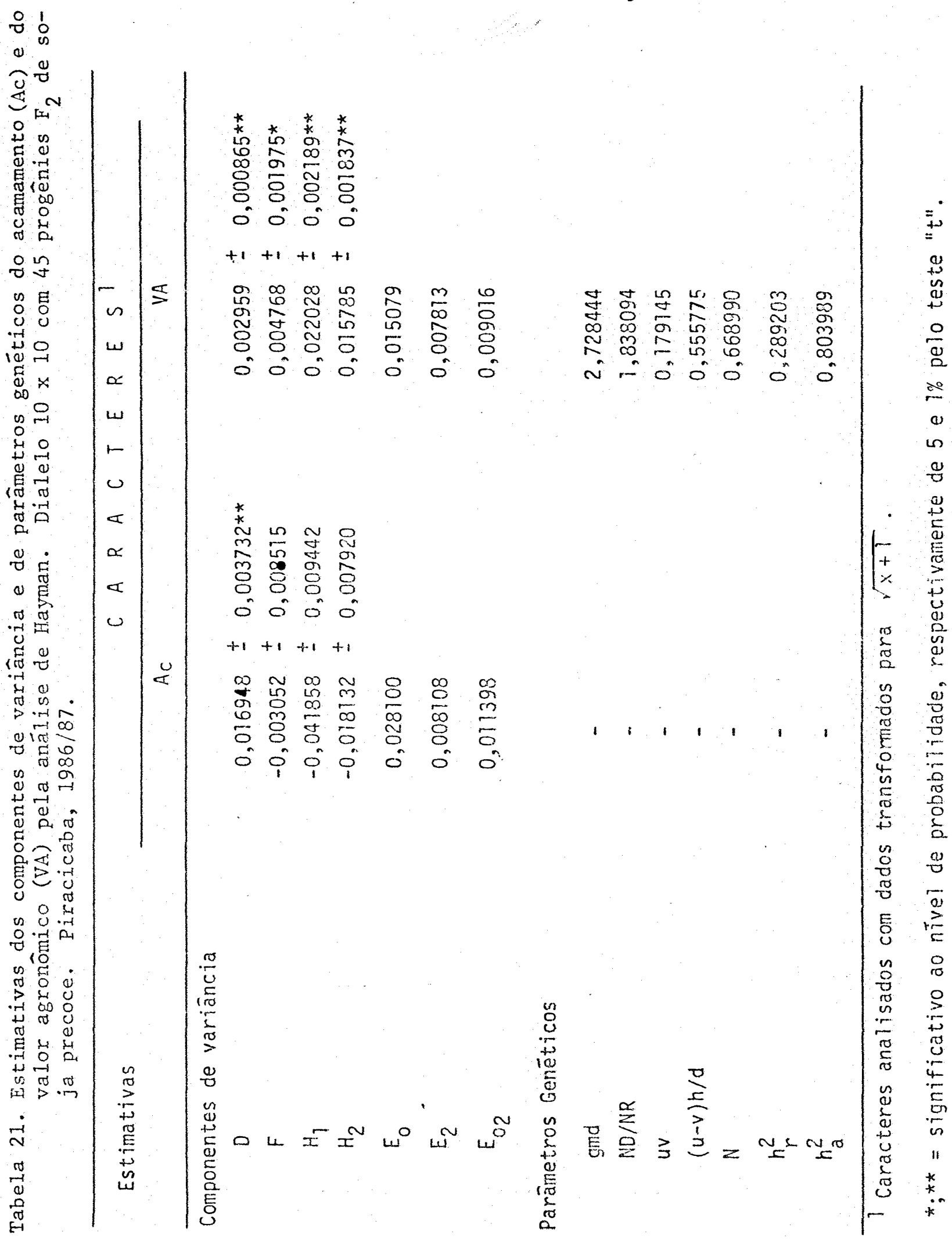




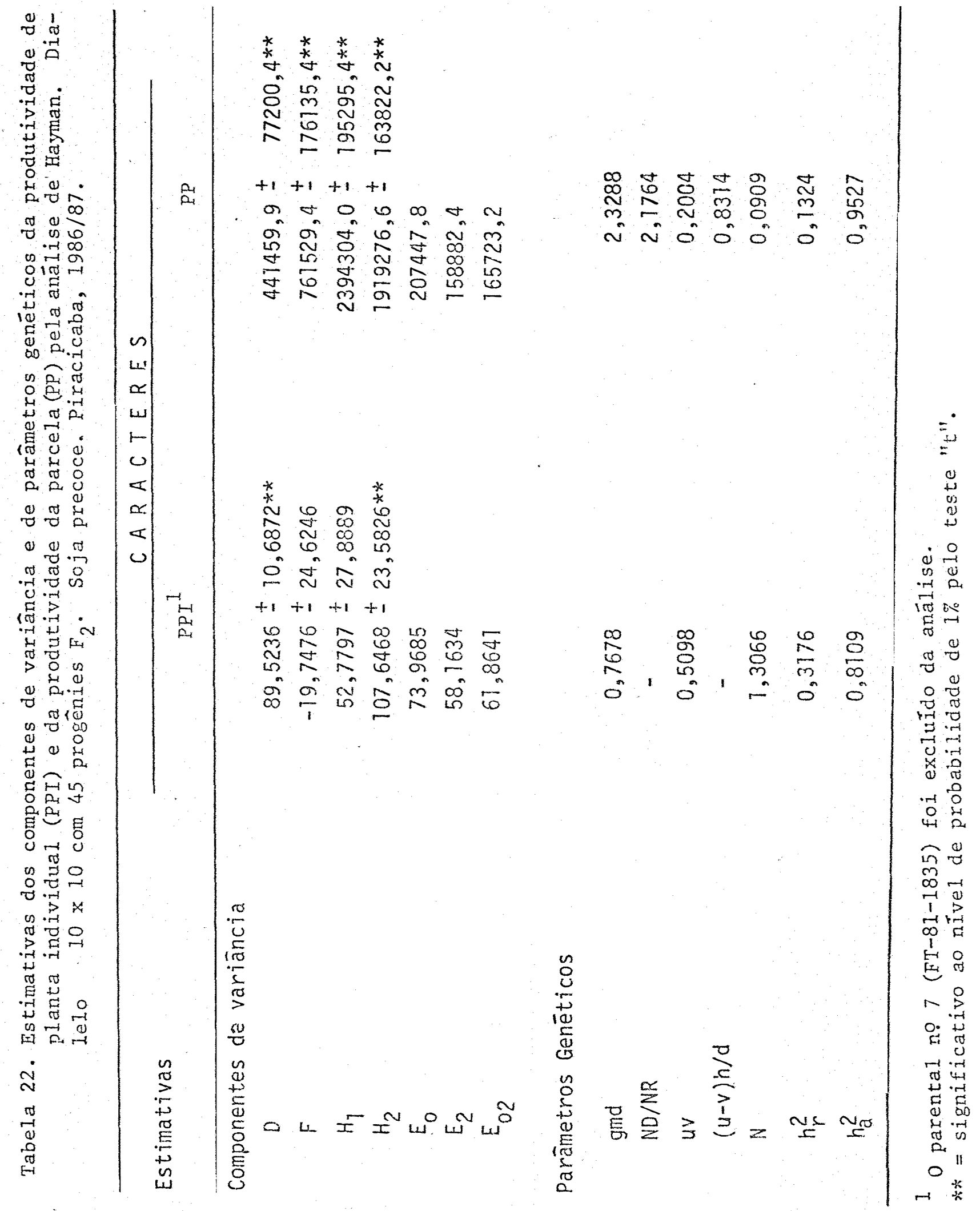




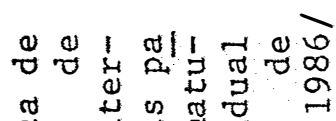
蹒

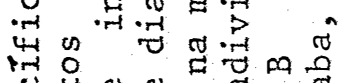

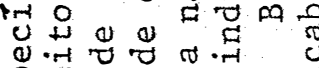

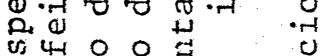

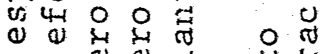
ब क क है

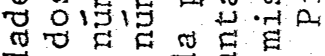

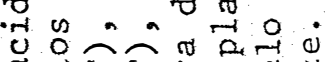

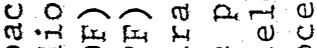

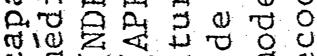
U

ब क 00 \%

苟若要 $N$

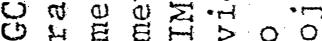

娚.

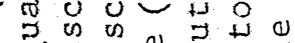

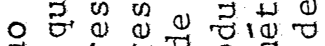
i

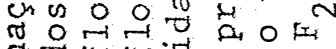

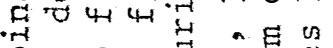

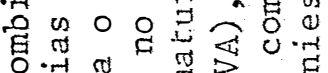
ช.

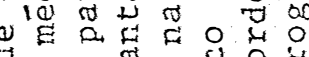
o o os

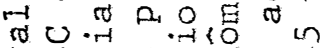

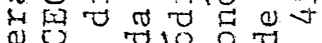

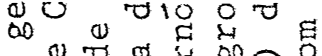
0 व

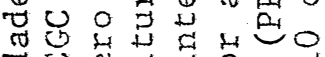
00 a $-1 . A^{2} 0$

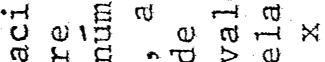

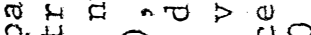

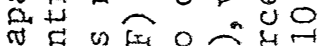

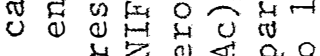

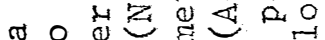

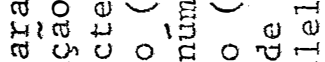

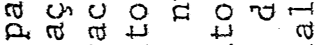
$\pi$ ब

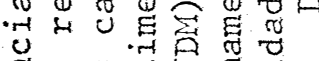

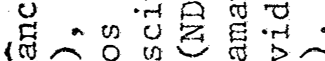

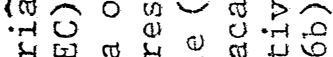

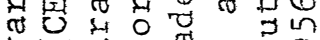

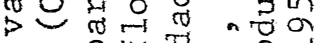

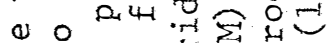

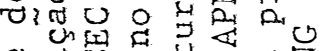
(1) थुछ

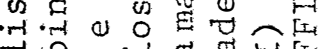
㟧

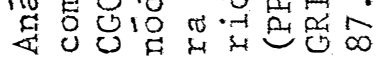

$\dot{\sim}$

$\underset{\substack{-1 \\ 0}}{\pi}$

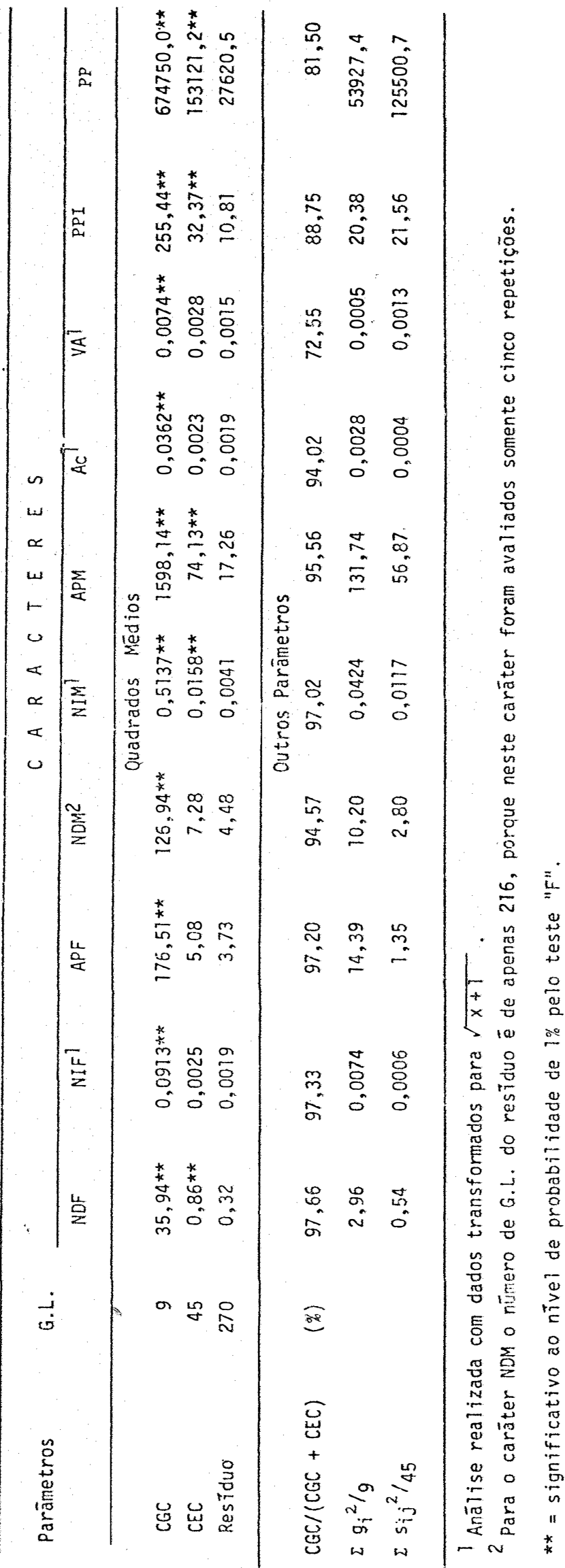




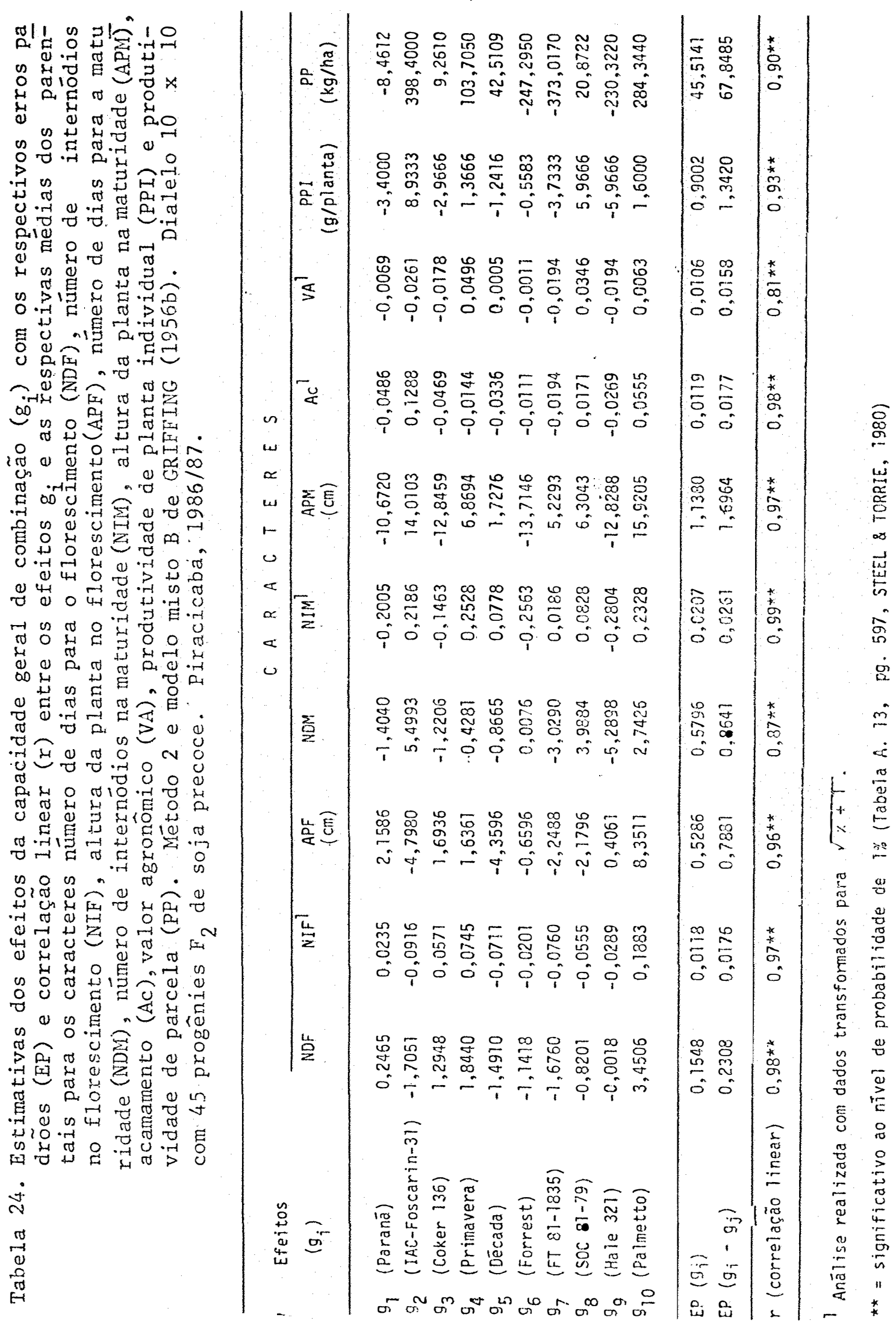




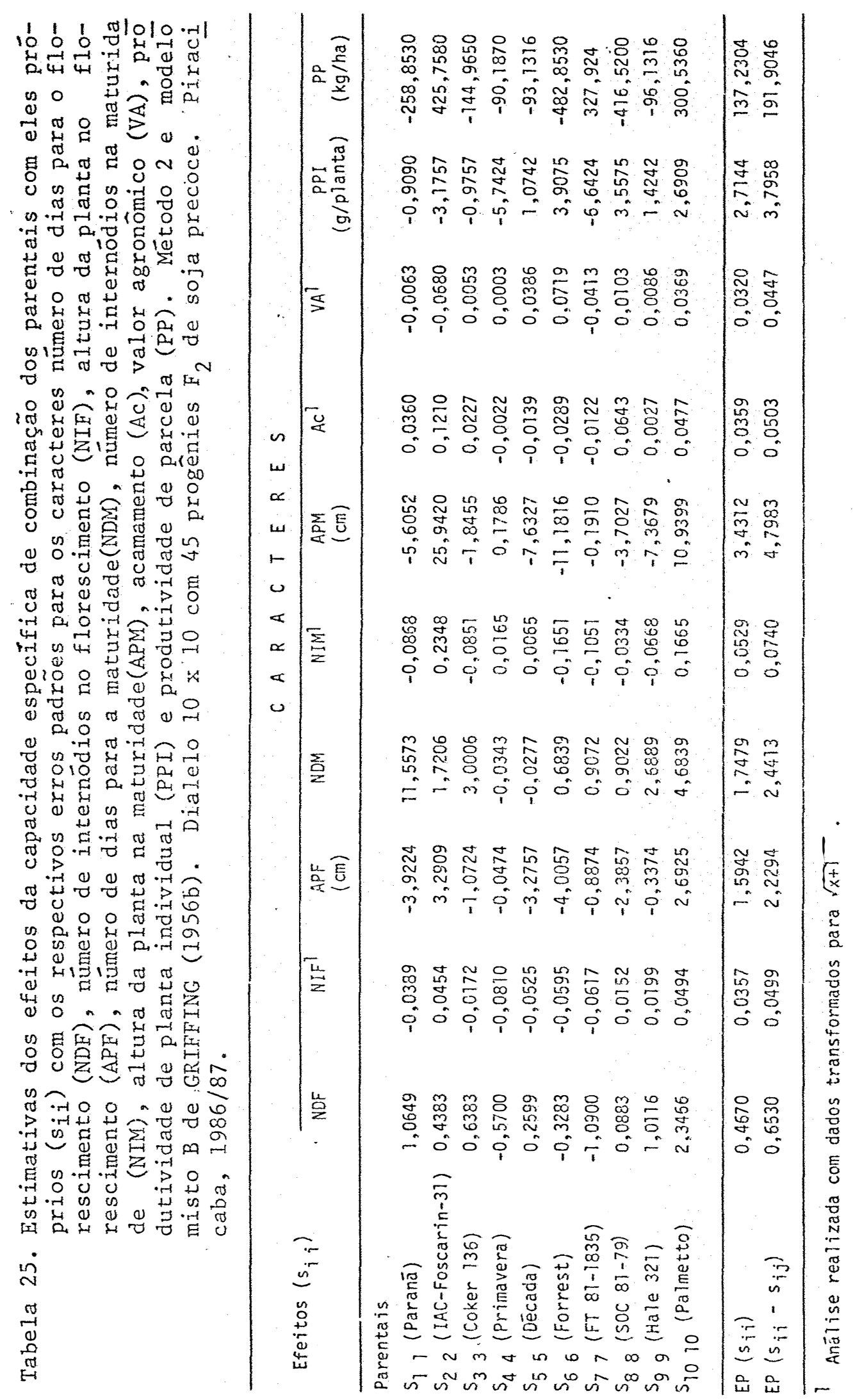




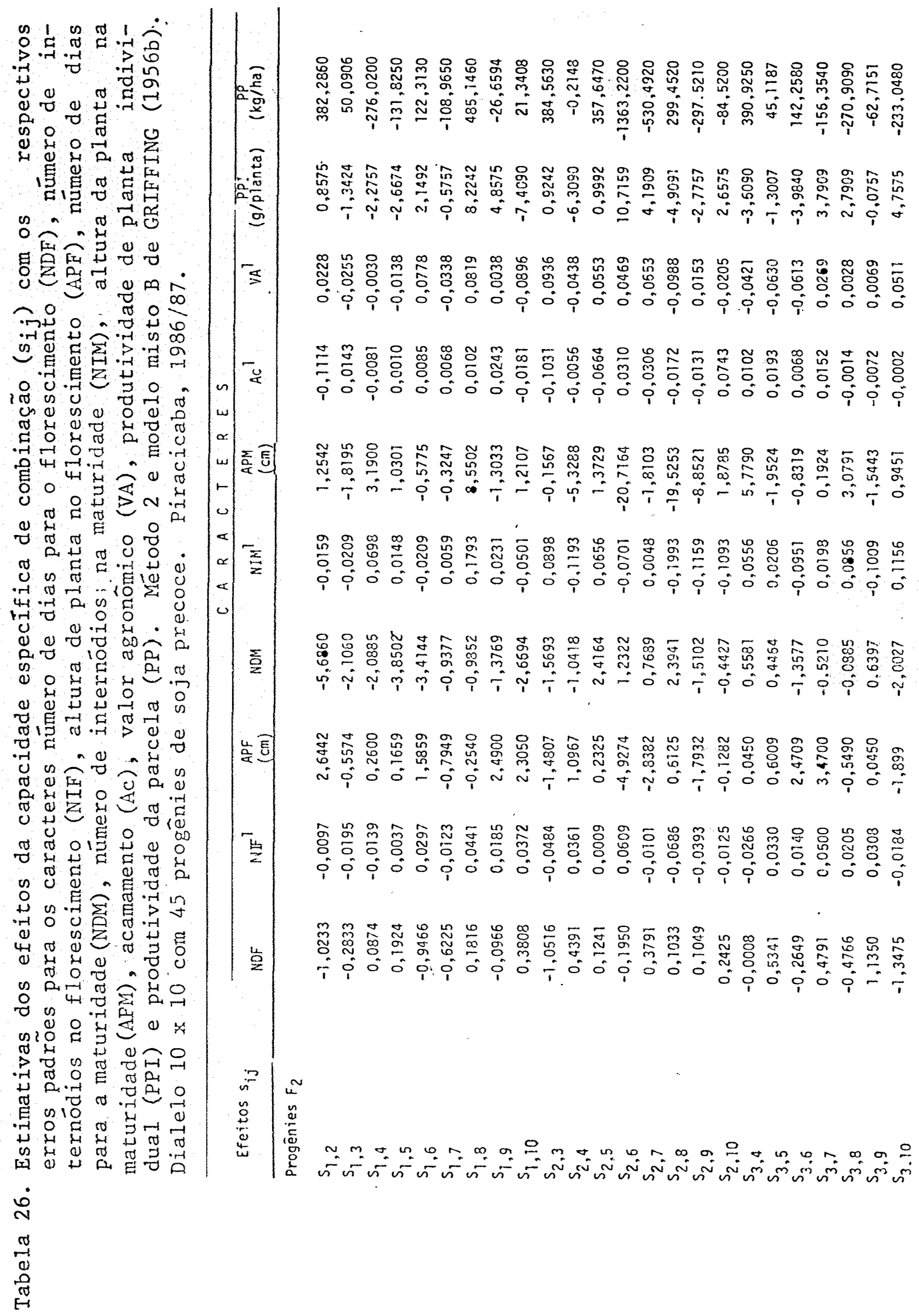




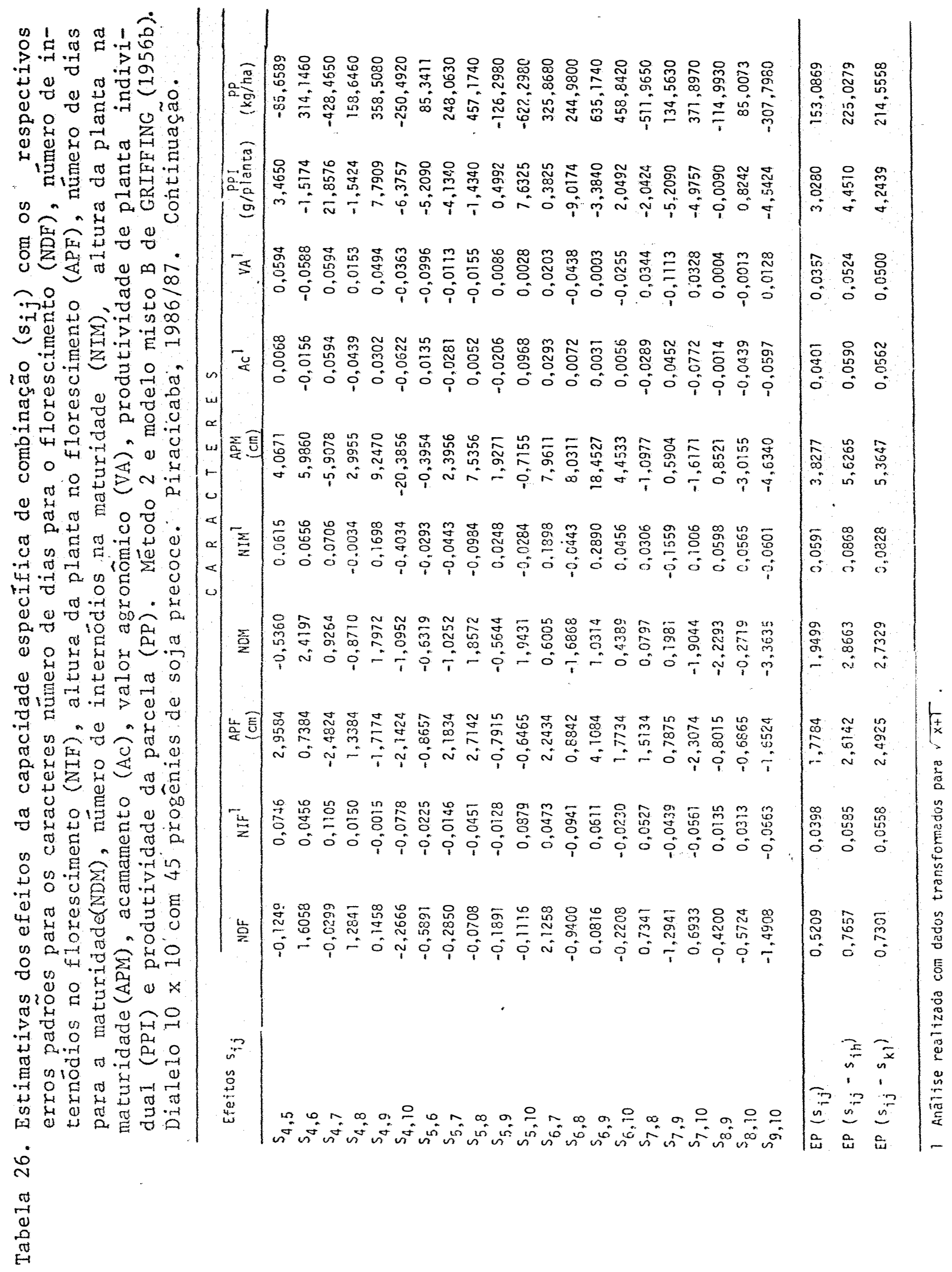




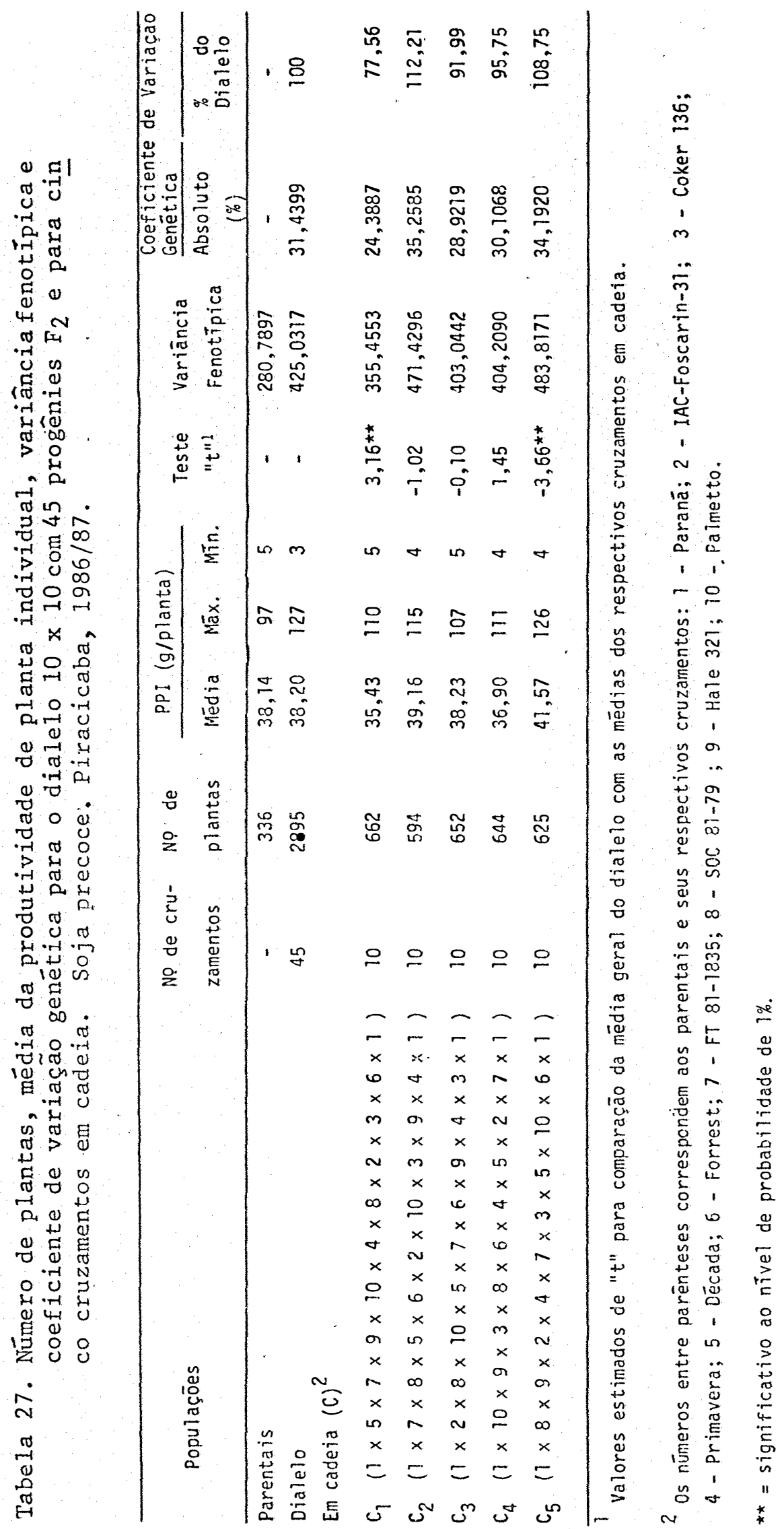


FIGURAS 

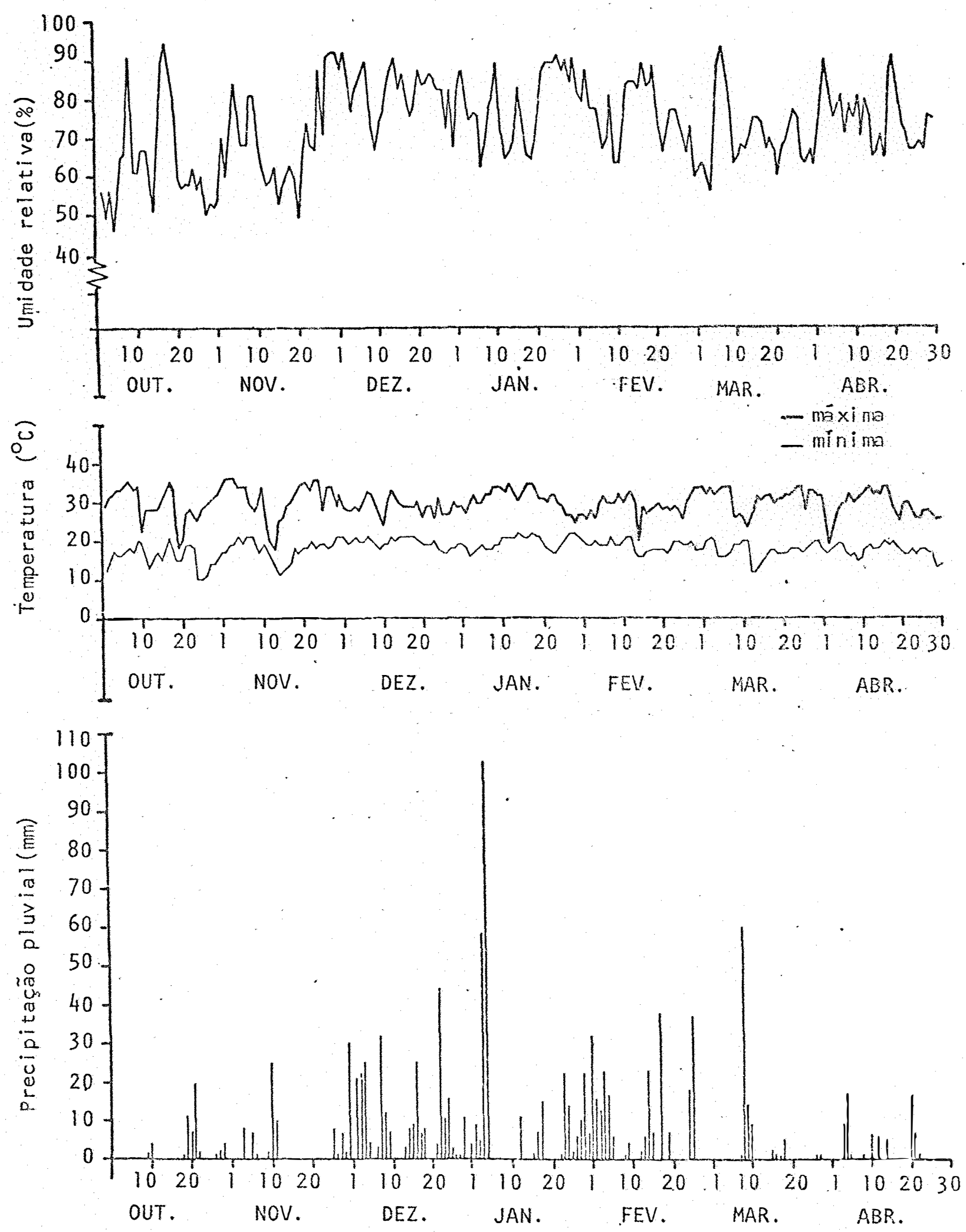

Figura 1. Umidade relativa do ar, temperaturas máxima e mínima e precipitação pluvial diäria do período de outubro/86 a abril/87, no município de Piracicaba-SP.

Fonte: Departamento de Física e Meteorologia da ESALQ/USP. 
218 .

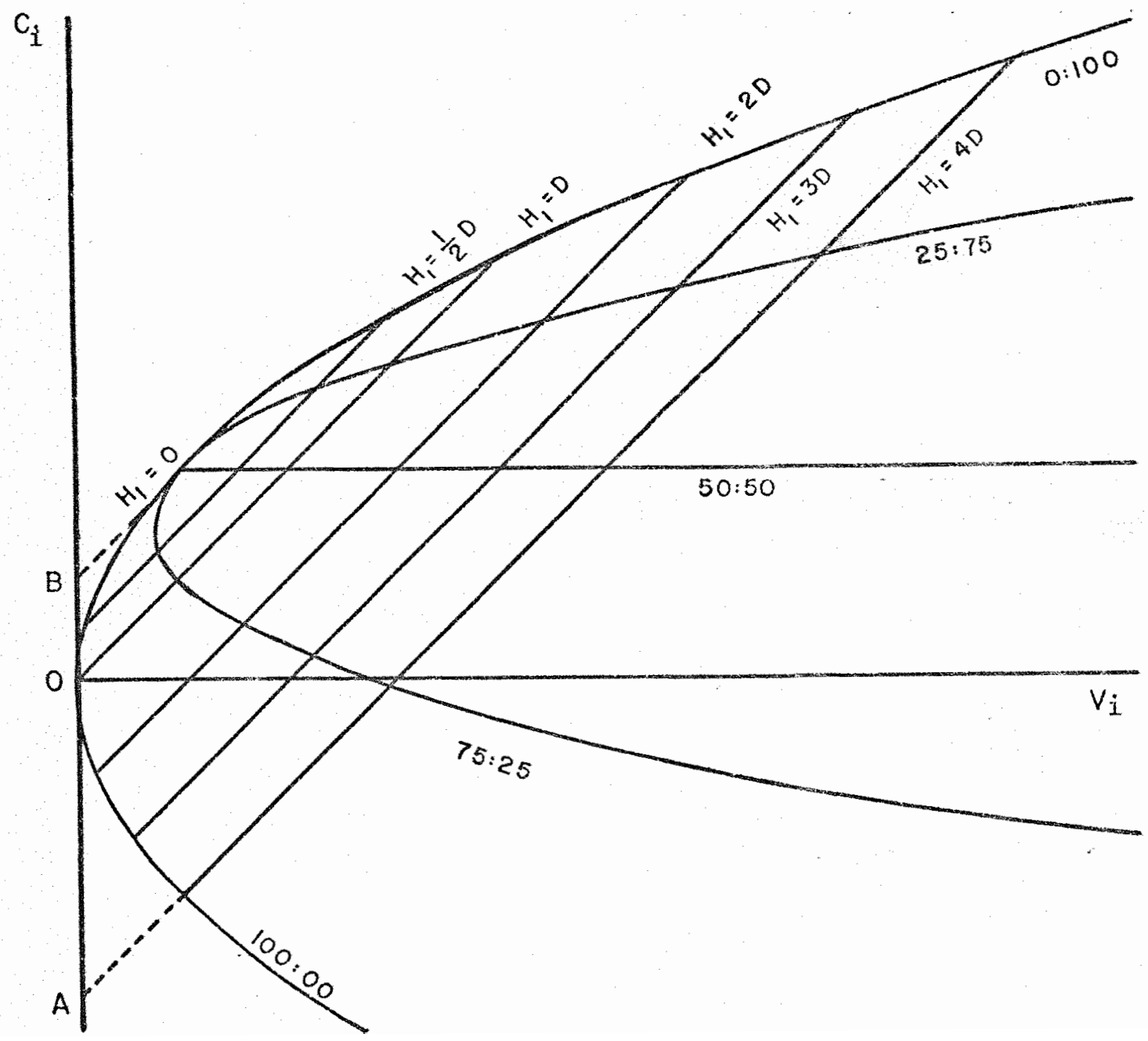

Figura 2. Relações teôricas de dominância em termos de variância $\left(V_{i}\right)$ das progênies do i-ésimo parental e da covariância $\left(C_{i}\right)$ dessas progê nies com o parental não recorrente.

Fonte: HAYMAN (1954b). 

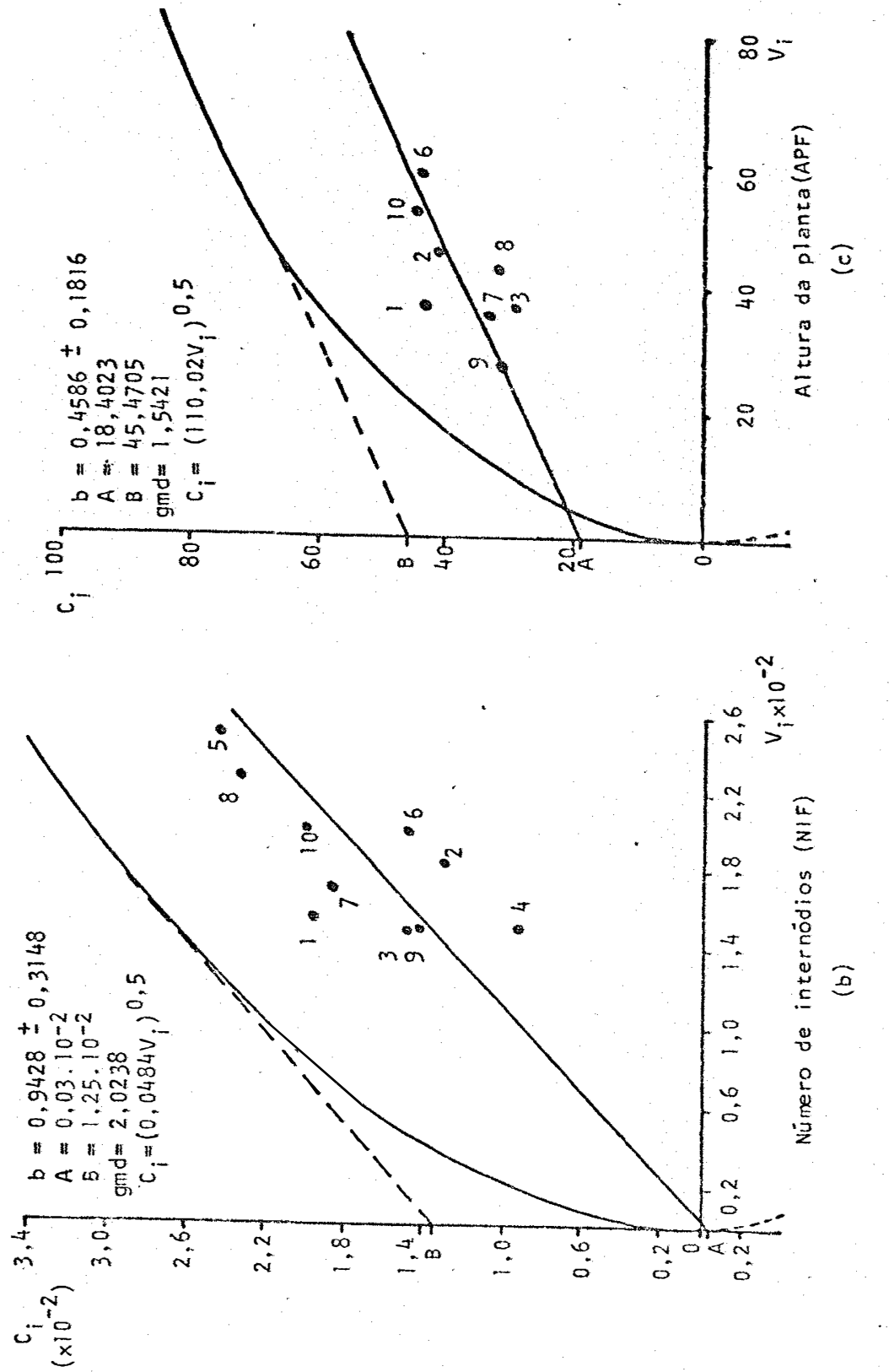

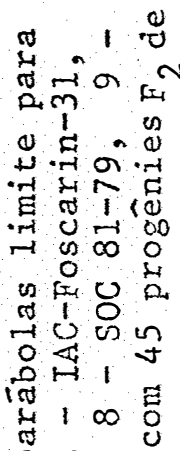

an ino

(1) लो

if

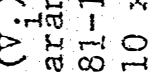

का 1 है

-

要然

क्ष०त की

$>$ is 0

is 0 \&

\&

- \& \& 2

$\begin{array}{lll}1 & 1 \\ 0 & 0 & 0 \\ 0 & 0\end{array}$

क $0^{0}$

न्मी

$00 \%$

- $\begin{gathered}\text { तु } \\ 0\end{gathered}$

si 400

of 1010

रा 0 का

-1 5 . 0

$\rightarrow 0 \overbrace{}^{4}$

ठ

o 0 욜

की

वन्त है है

1010

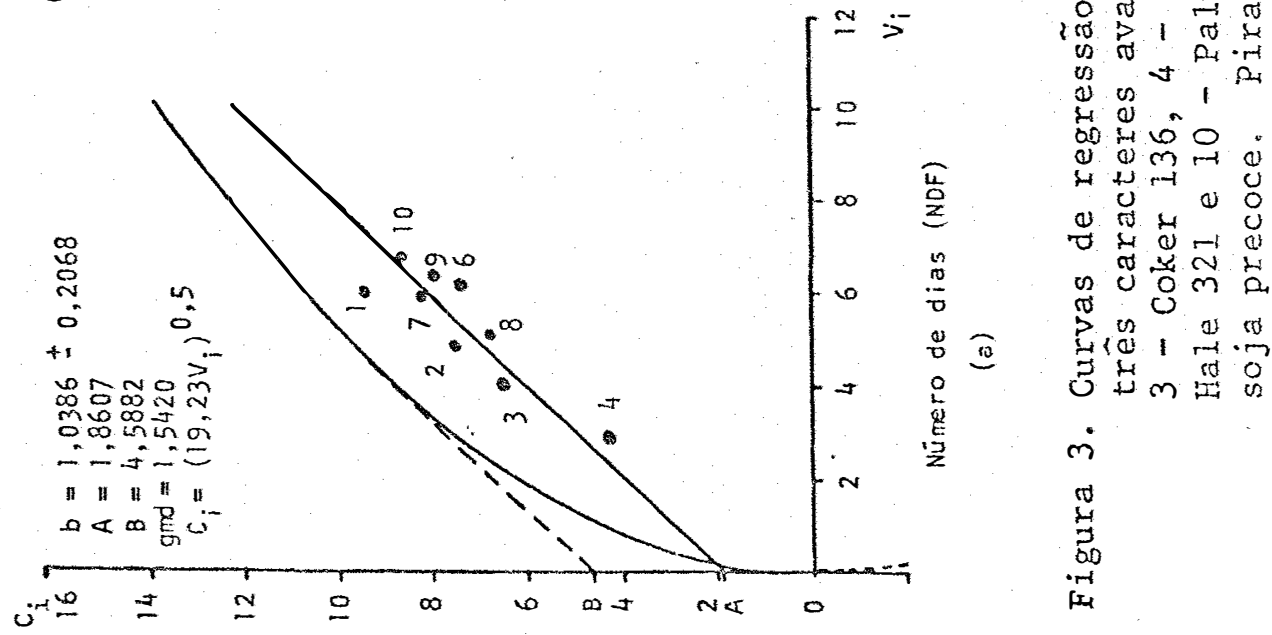




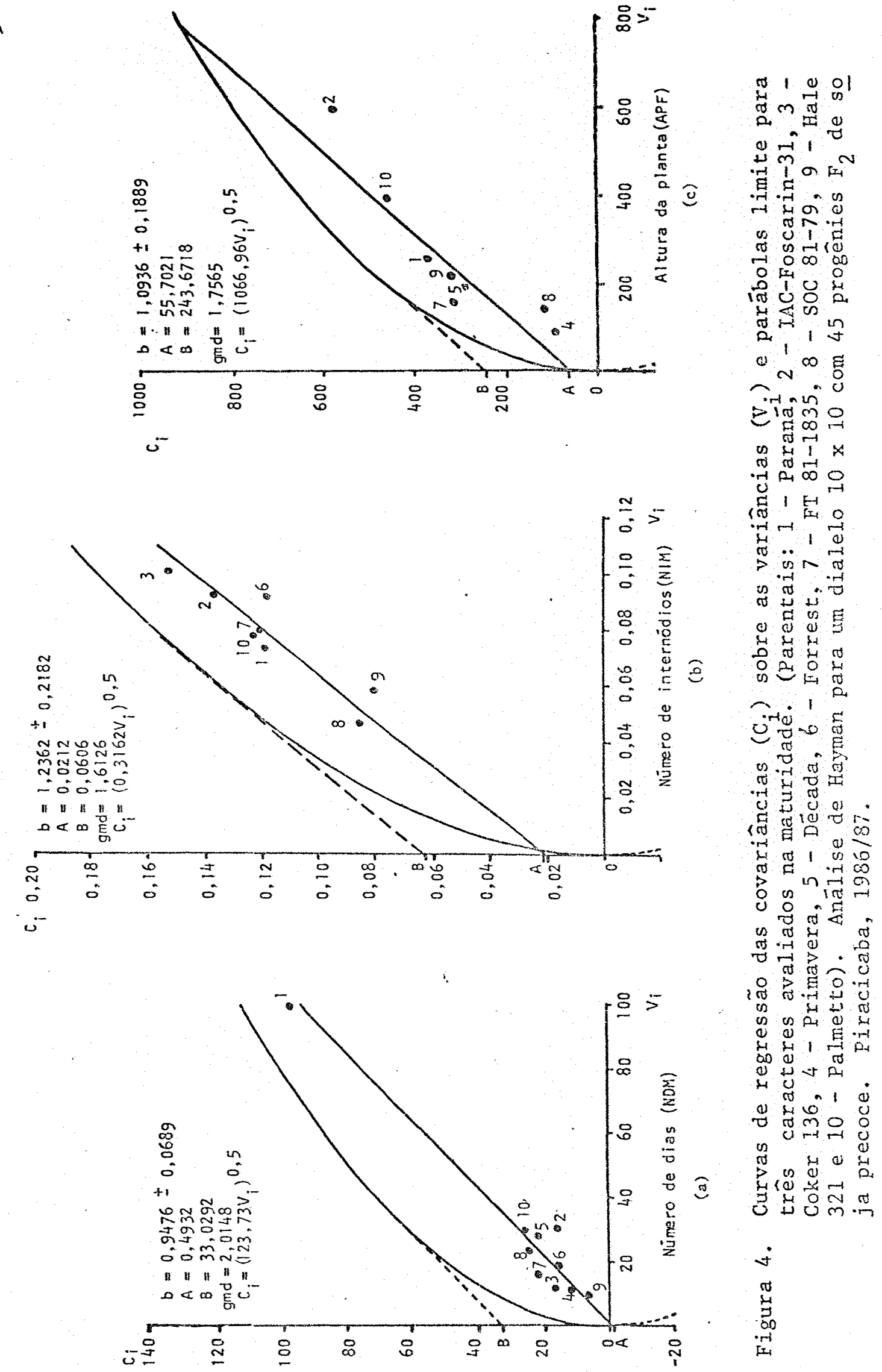




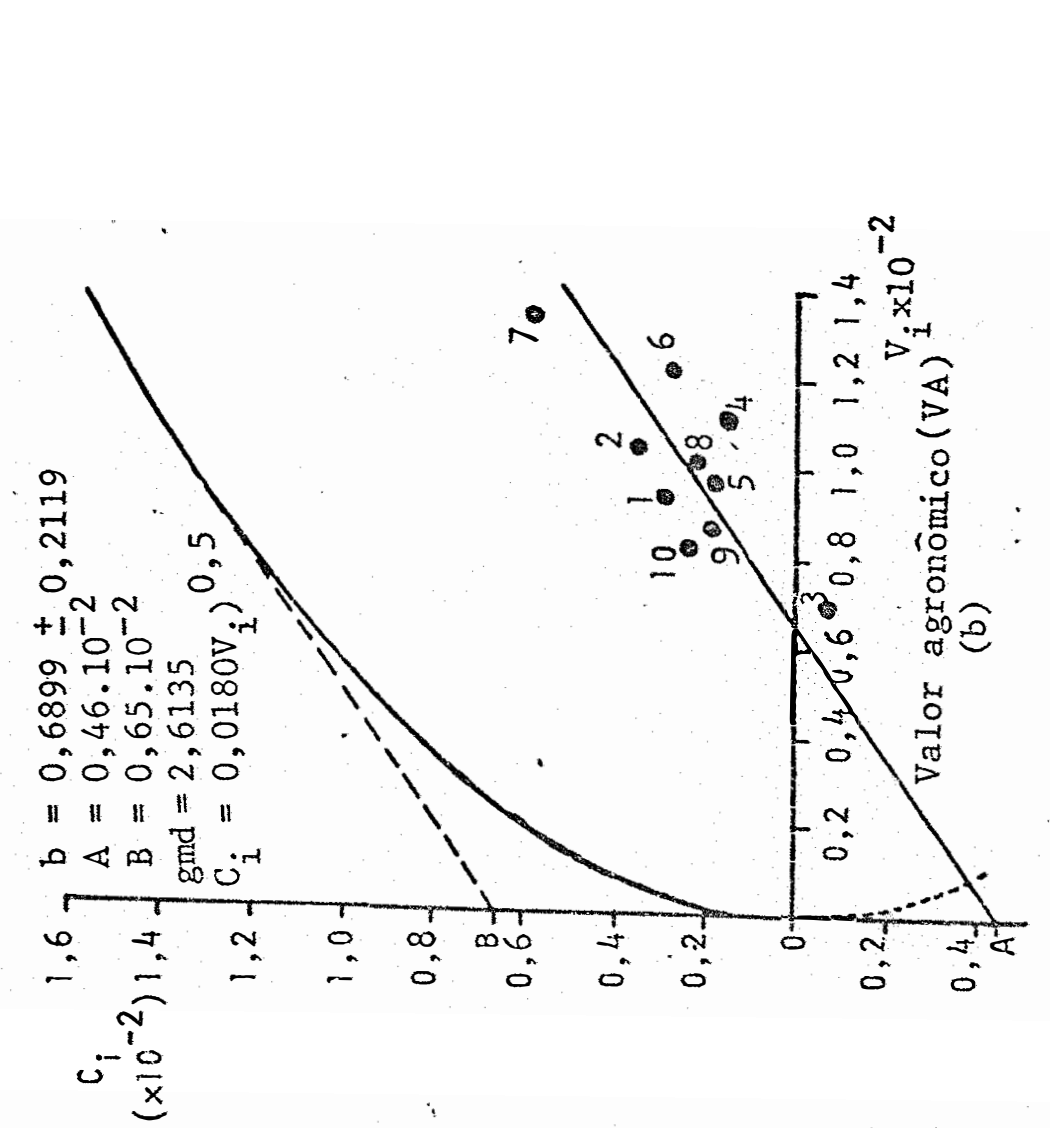

.

om

कै 1 क्ष

要

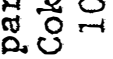

010

स $m$ ते

- त -10

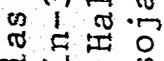

rit

तथ

त्र

है की

(c) 1 क

a.

$P^{-1} \quad 0_{0}$

त $N$ is

प्रात्व 1 D

(ब

मे म

ก ल ल

थ $1 \frac{1}{1} 0$

(1.. $x$

औ is Ex

0 倠

य 151

नित् 0

(2) 0 in od

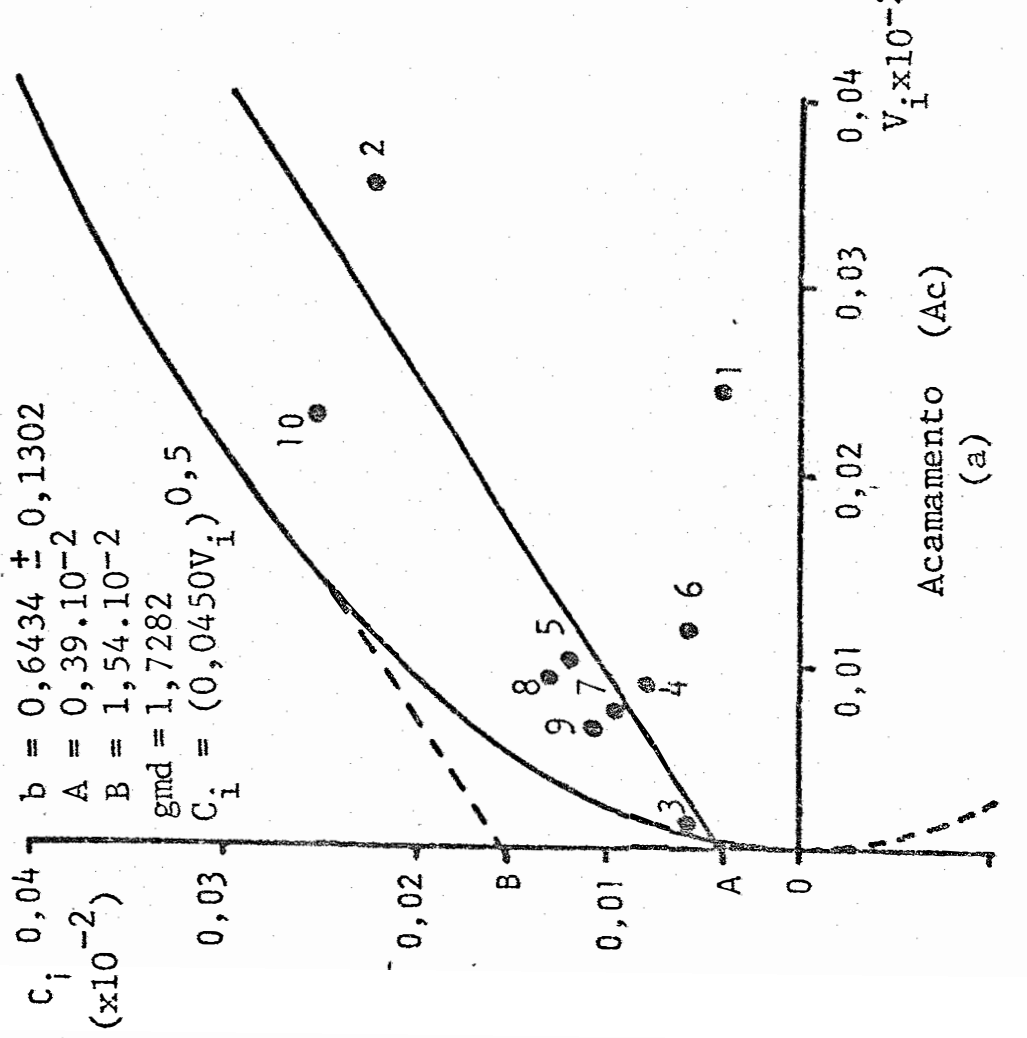

क ब

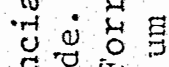

द व

(0)

म 400

b. 㟧

บ 医

v d U

व द 10

ช 000

ख च 1 च

os. in en 0 .

\&.

$00 \int^{\infty}-1$

-

भ क 5

$\nabla$ \&

(1)

to 0 出 0

ए 120

光

in

0
4
5
0
01
01
61 

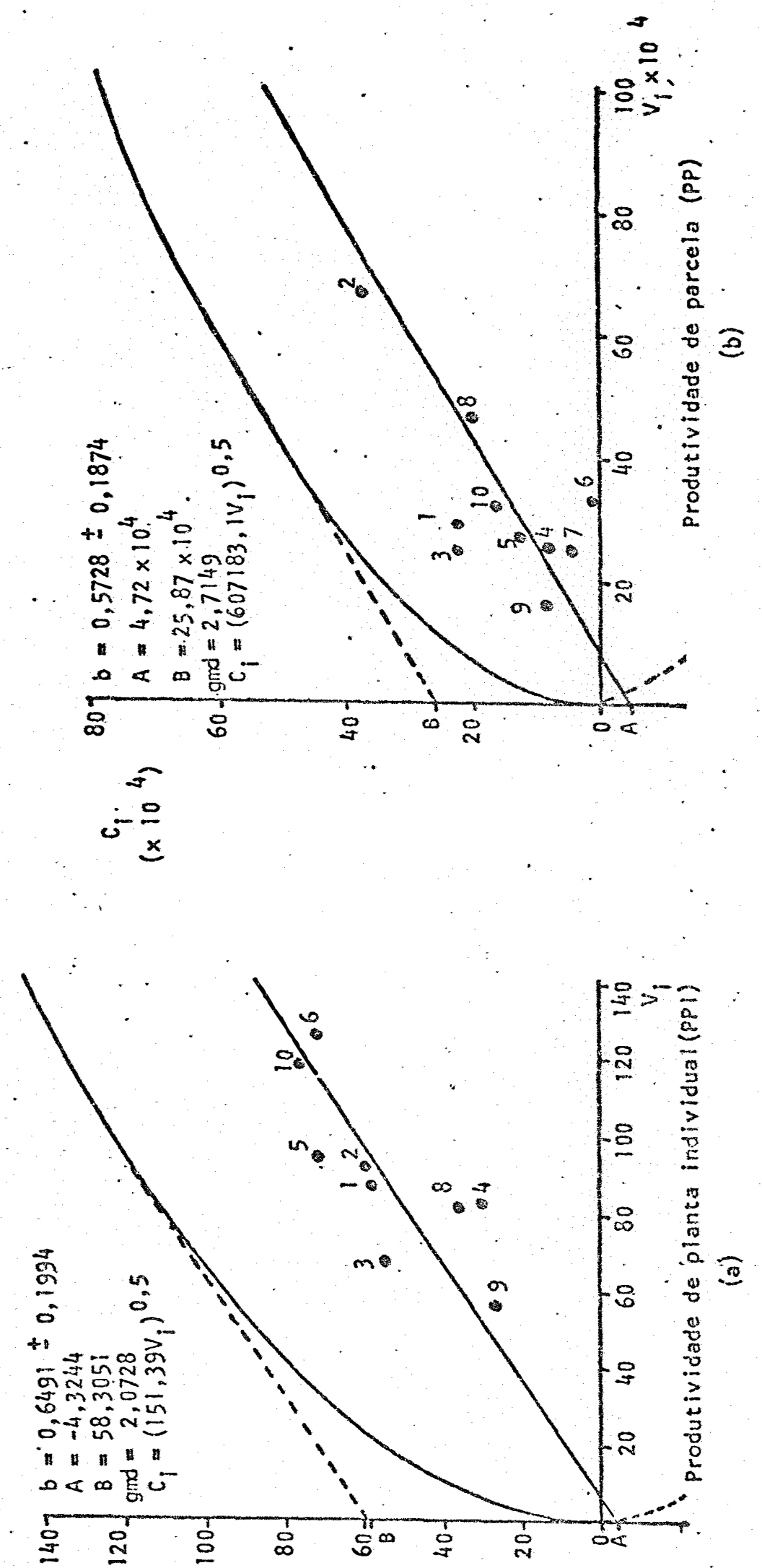

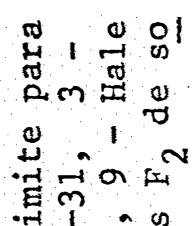

- 400

बन

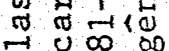

$\therefore: 0:$

गु क्षि

खै ป ज

- 100

Prvin

in?

os ${ }^{10} x$

.

.

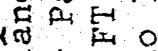

$\operatorname{lin}_{-1}, 1,0$

$\rightarrow-\pi$

is $\ddot{s}$ न

ब.

- I 85

过

का 4 क त

$\sim D^{\infty}$

0

का

क्ष

गु 300

दूत्व

$\rightarrow \sigma^{-}, \infty$

बा $1, \infty$

\% थ थ

o 20

क. 을

$\pi \cdot \pi, \frac{\pi}{0}$

त्न 00

2000

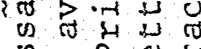

of is क $^{2}$.

\& $\& 1$ :

$004+5$

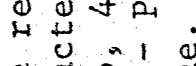

\&

勿

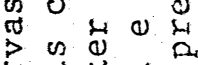

? ${ }^{n} \stackrel{0}{-1} \rightarrow$ D

गु

0

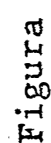




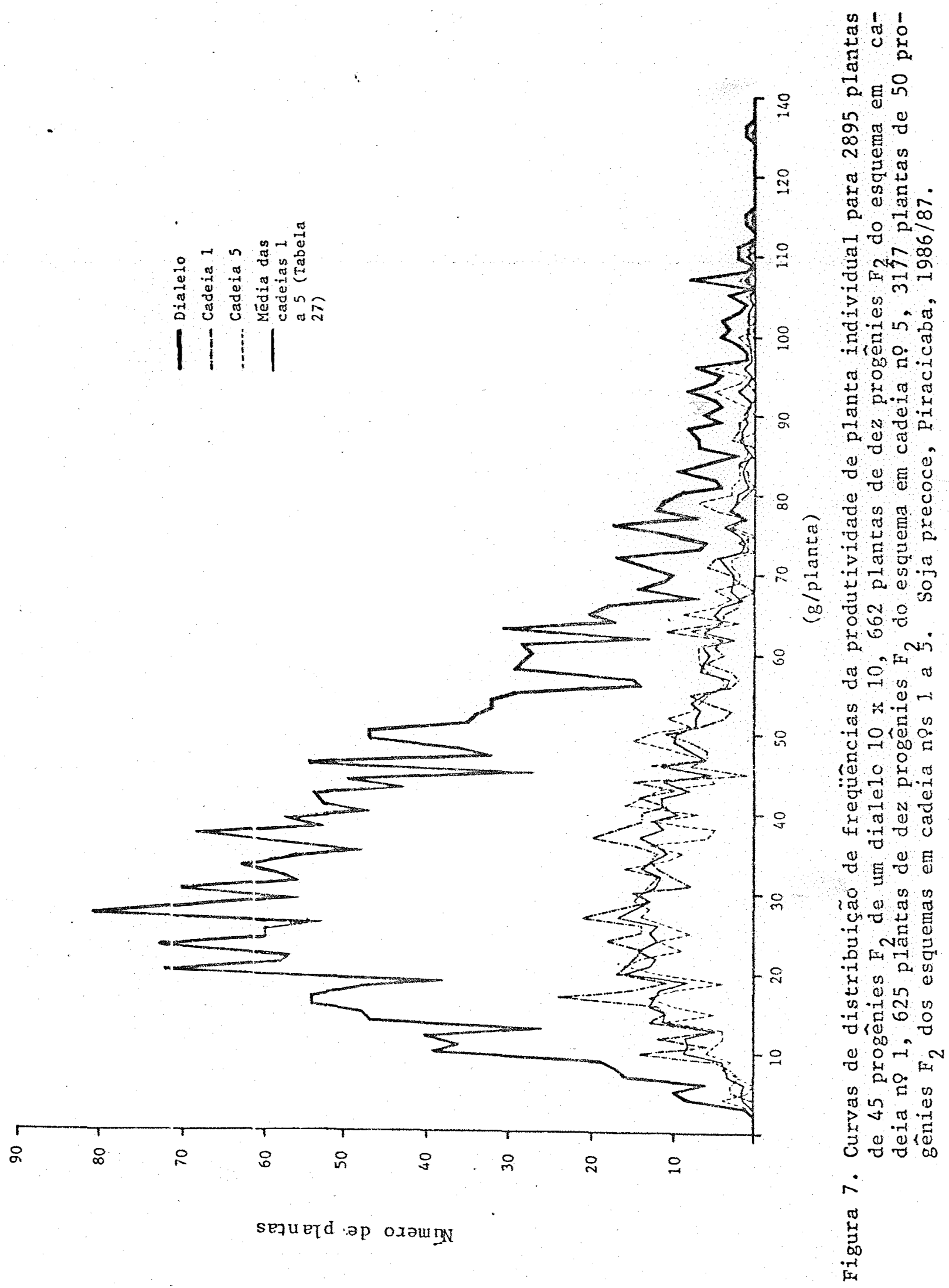




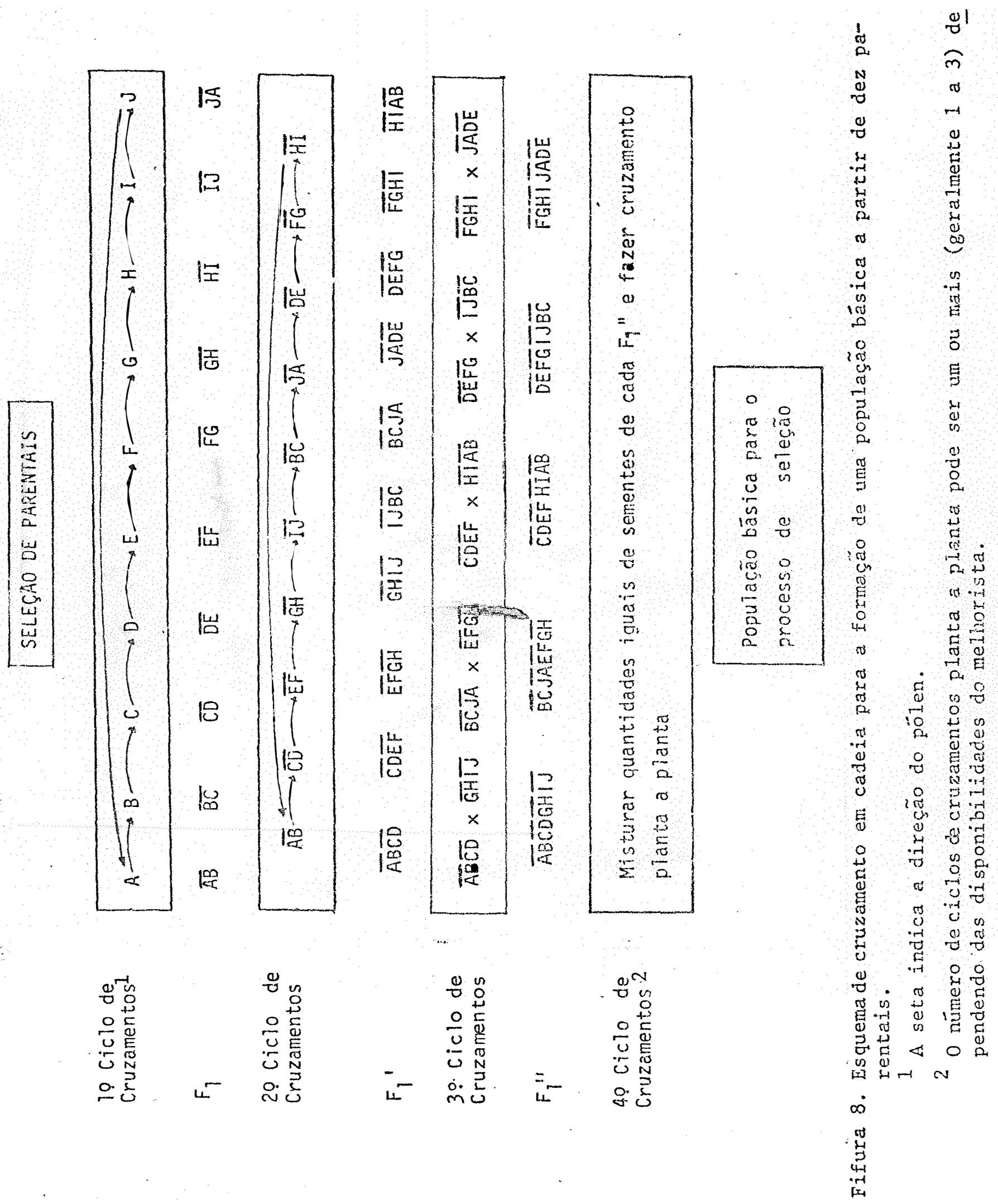

